Prepared in cooperation with the Missouri River Recovery-Integrated Science Program U.S. Army Corps of Engineers, Yankton, South Dakota

\title{
Ecological Requirements for Pallid Sturgeon Reproduction and Recruitment in the Missouri River-Annual Report 2013
}
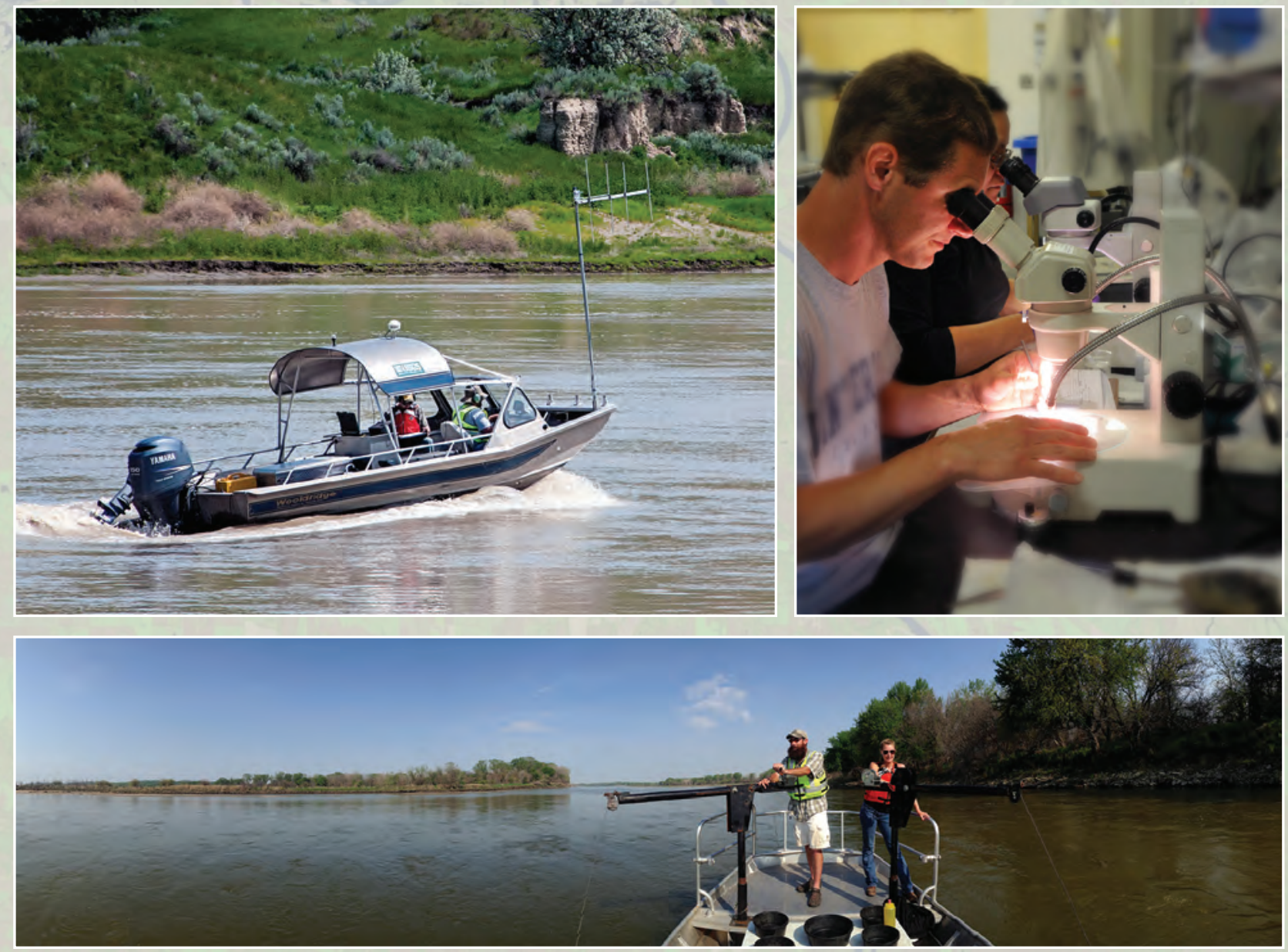

Open-File Report 2015-1197

U.S. Department of the Interior

U.S. Geological Survey 
Cover. LANDSAT image of the area around the confluence of the Platte and Missouri Rivers on September 23, 2013 (background). Radio tracking pallid sturgeon on the Missouri River (upper left, photograph by Aaron DeLonay, June 2013). Researchers microscopically examine pallid sturgeon eggs (upper right, photograph by Kimberly Chojnacki, May 2013). Sampling for sturgeon free embryos and larvae in the Missouri River near Omaha, Nebraska (lower, photograph by Beau Griffith, May 2013). 


\section{Ecological Requirements for Pallid Sturgeon Reproduction and Recruitment in the Missouri River-Annual Report 2013}

By Aaron J. DeLonay, Robert B. Jacobson, Kimberly A. Chojnacki, Patrick J. Braaten, Kevin J. Buhl, Brandon L. Eder, Caroline M. Elliott, Susannah O. Erwin, David B. Fuller, Tyler M. Haddix, Hallie L.A. Ladd, Gerald E. Mestl, Diana M.

Papoulias, Jason C. Rhoten, Christopher J. Wesolek, and Mark. L. Wildhaber

Prepared in cooperation with the Missouri River Recovery-Integrated Science Program, U.S. Army Corps of Engineers, Yankton, South Dakota

Open-File Report 2015-1197 


\title{
U.S. Department of the Interior SALLY JEWELL, Secretary
}

\section{U.S. Geological Survey Suzette M. Kimball, Director}

\author{
U.S. Geological Survey, Reston, Virginia: 2016
}

For more information on the USGS - the Federal source for science about the Earth, its natural and living resources, natural hazards, and the environment—visit http://www.usgs.gov or call 1-888-ASK-USGS.

For an overview of USGS information products, including maps, imagery, and publications, visit http://www.usgs.gov/pubprod/.

Any use of trade, firm, or product names is for descriptive purposes only and does not imply endorsement by the U.S. Government.

Although this information product, for the most part, is in the public domain, it also may contain copyrighted materials as noted in the text. Permission to reproduce copyrighted items must be secured from the copyright owner.

Suggested citation:

DeLonay, A.J., Jacobson, R.B., Chojnacki, K.A., Braaten, P.J., Buhl, K.J., Eder, B.L., Elliott, C.M., Erwin, S.O., Fuller, D.B., Haddix, T.M., Ladd, H.L.A., Mestl, G.E., Papoulias, D.M., Rhoten, J.C., Wesolek, C.J., and Wildhaber, M.L., 2016, Ecological requirements for pallid sturgeon reproduction and recruitment in the Missouri River-Annual report 2013: U.S. Geological Survey Open-File Report 2015-1197, 99 p., http://dx.doi.org/10.3133/ofr20151197.

ISSN 2331-1258 (online) 


\section{Acknowledgments}

This report benefitted from technical reviews by Dr. Martin Hamel of the University of NebraskaLincoln and Dr. Dan James of the U.S. Fish and Wildlife Service, Pierre, South Dakota. Funding for this research was provided by the U.S. Army Corps of Engineers, Missouri River RecoveryIntegrated Science Program and the U.S. Geological Survey. The authors gratefully acknowledge the collaboration in the capture, handling, culture, and transport of pallid sturgeon for this study by the U.S. Fish and Wildlife Service, Columbia Fish and Wildlife Conservation Office, U.S.

Fish and Wildlife Service, Gavins Point and Neosho National Fish Hatcheries, Nebraska Game and Parks Commission, South Dakota Game, Fish, and Parks, and the Missouri Department of Conservation. 



\section{Contents}

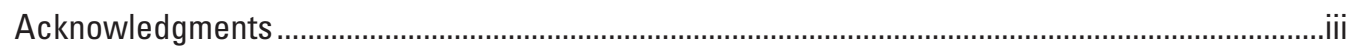

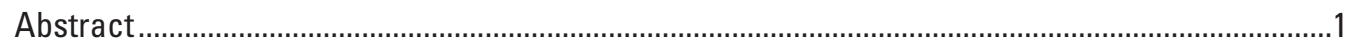

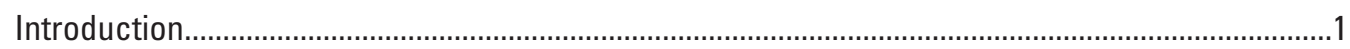

Comprehensive Sturgeon Research Project 2013 Scope of Work ..................................................

Hydroclimatic Conditions During 2013 .....................................................................................

Task 1. Movement, Habitat Use, and Reproduction of Pallid Sturgeon in the Lower

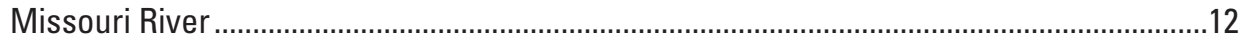

Movement, Habitat Use, and Reproductive Behavior of Pallid Sturgeon ...............................13

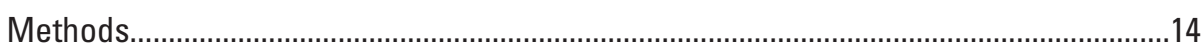

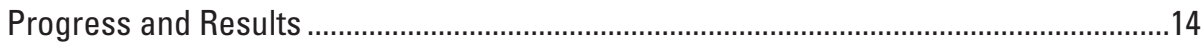

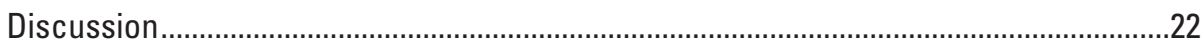

Habitat Use and Availability during Migration, Spawning, and Drift ....................................23

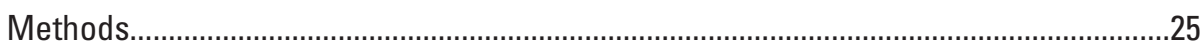

Habitat and Habitat Dynamics at Spawning and Free-Embryo Drift Sites..............25

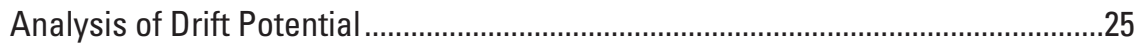

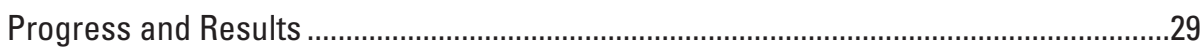

Habitat and Habitat Dynamics at Spawning and Hatching Sites ............................29

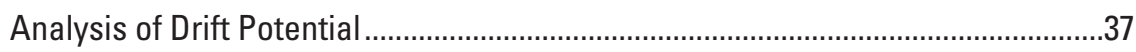

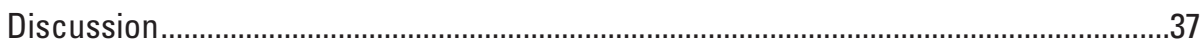

Field Studies of Embryo, Larvae, and Young-of-Year Dispersal, Distribution, and

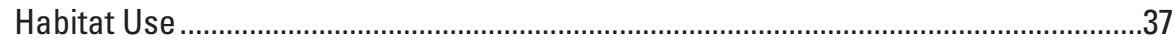

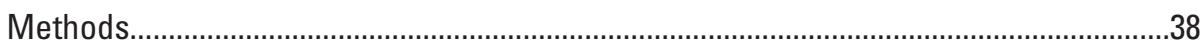

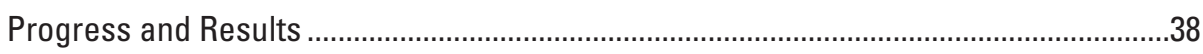

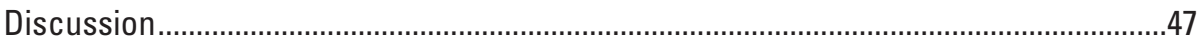

Data Coordination, Integration, Geospatial Analysis and Outreach ......................................47

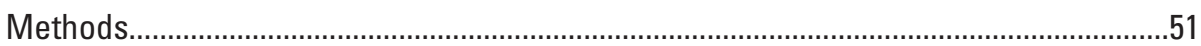

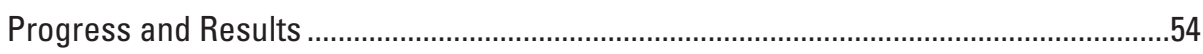

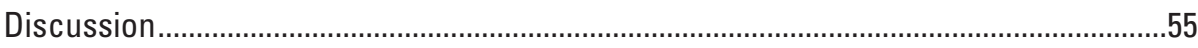

Task 2. Reproduction, Habitat Use, and Early Life Stage Dynamics of Pallid Sturgeon in the Yellowstone River ..............................................................................................................55

Migration Pathways, Habitat Use, and Reproduction of Pallid Sturgeon in the

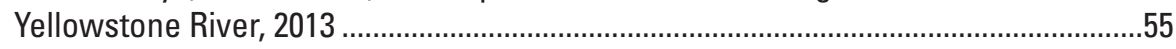

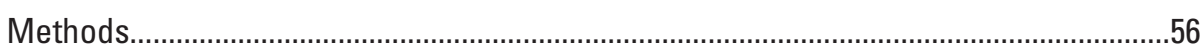

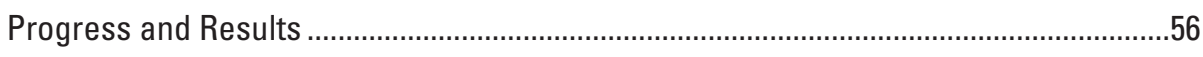

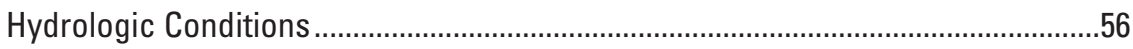

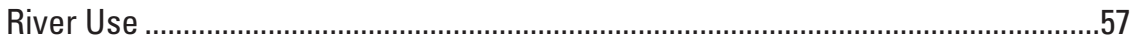

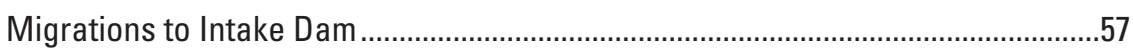

Spawning Chronology of Female Pallid Sturgeon Codes 40 and 41 ........................57

Verification of Pallid Sturgeon Hatch and Drift Entry ...............................................61

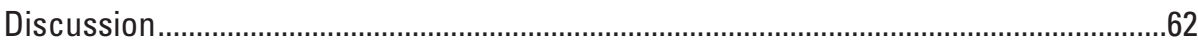

Determine Habitat Use and Availability during Migration, Spawning, and Drift of Pallid

Sturgeon in the Upper Missouri and Yellowstone Rivers ................................................63 


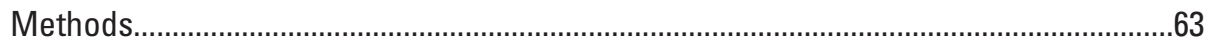

Habitat and Habitat Dynamics at Spawning and Hatching Sites ............................63

Analysis of Drift Potential .........................................................................................63

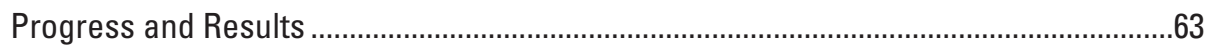

Habitat and Habitat Dynamics at Spawning and Hatching Sites ............................63

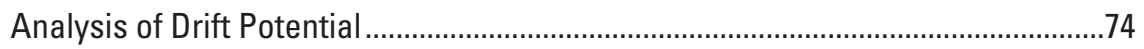

Database Integration, GIS Support, Coordination, and Outreach .........................................74

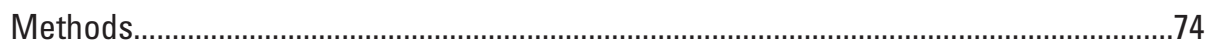

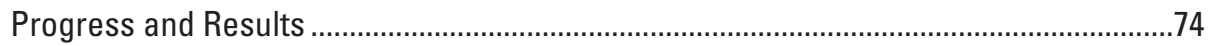

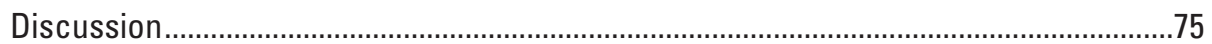

Task 3. Examination of Pallid Sturgeon Use, Migrations and Spawning in the Milk River and Missouri River below Fort Peck Dam during 2013 ....................................................75

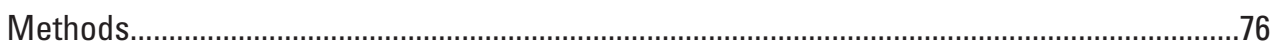

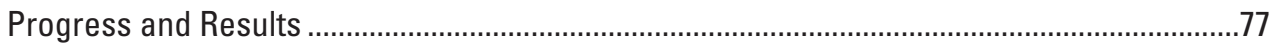

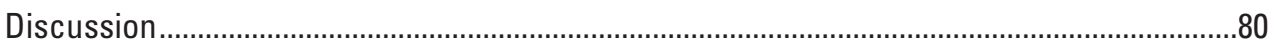

Task 5: Missouri River Pallid Sturgeon Population Assessment Program

Synthesis-Towards Understanding Population Trends of Pallid Sturgeon and Other Targeted Species.

Missouri River Pallid Sturgeon Population Assessment Program Synthesis-Relative

Abundance with Environmental Covariates and Bivariate Analyses..........................82

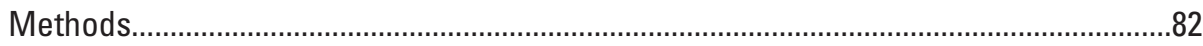

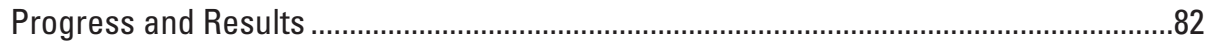

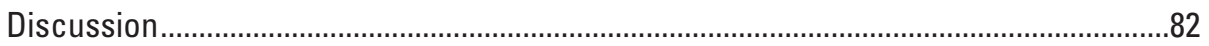

Missouri River Pallid Sturgeon Population Assessment Program synthesis-Tag

Retention Effects on and Spatial Context of Pallid Sturgeon Capture

Probability, Survival Rate, and Population Size.............................................................83

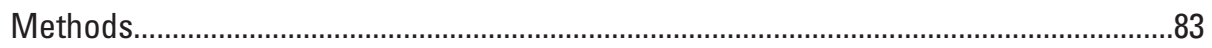

Progress and Results ............................................................................................

Missouri River Pallid Sturgeon Population Assessment Program Synthesis-Pallid

Sturgeon Population Model and Population Viability Analyses .....................................83

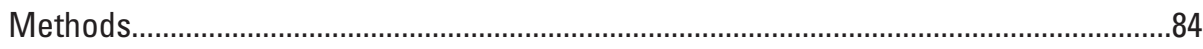

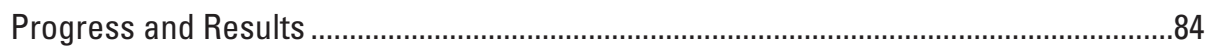

The Effect of Food, Temperature, and Turbidity on Substrate Selection of

Young-of-Year and Early Juvenile Missouri River Sturgeon and Associated

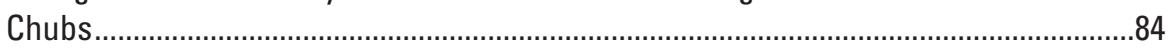

Methods

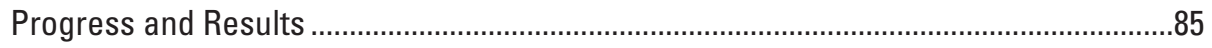

Task 6: Hatch, Dispersal and Settling Behavior of Early Life-Stage Pallid Sturgeon from

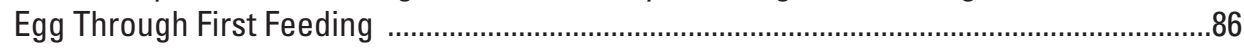

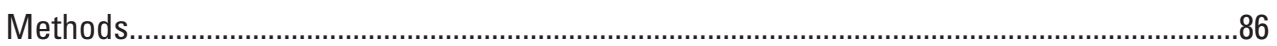

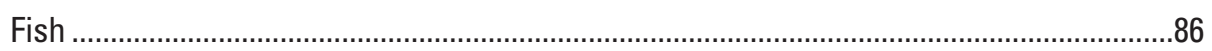

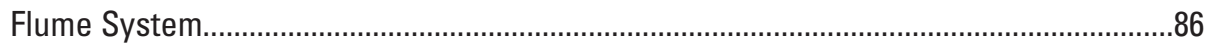

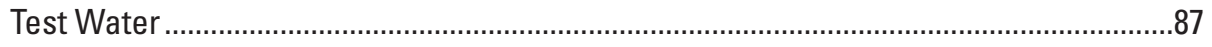

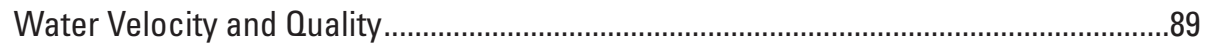

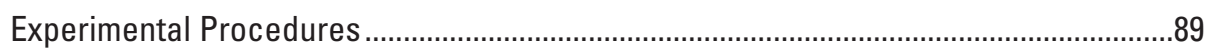

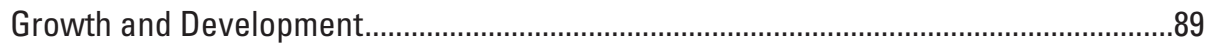

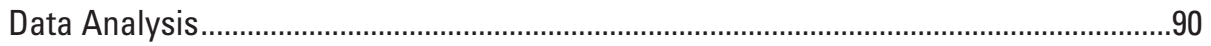




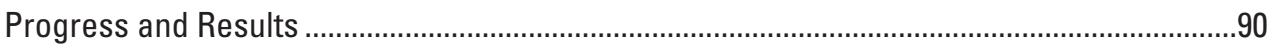

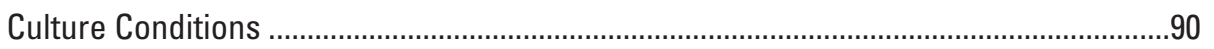

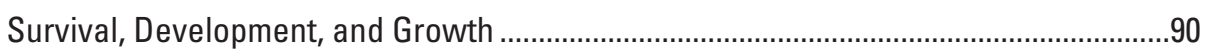

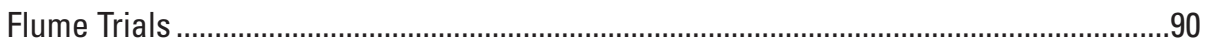

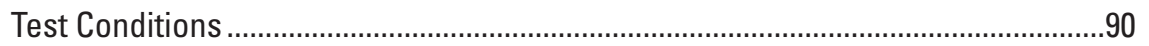

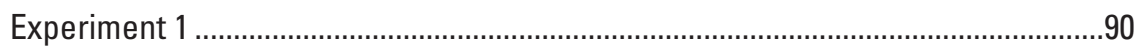

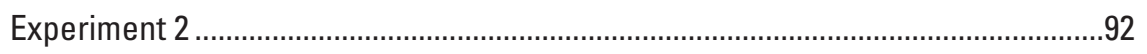

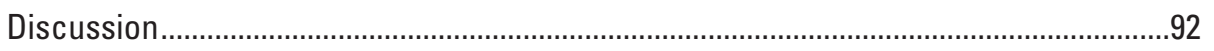

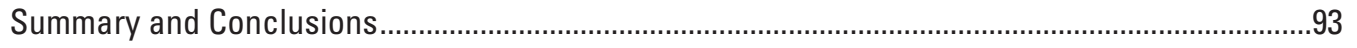

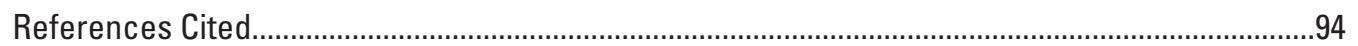

\section{Figures}

1. Map showing Missouri River Basin and major tributary rivers with the Comprehensive Sturgeon Research Project study areas..................................................

2. Diagram representing conceptual model of pallid sturgeon life history............................4

3. Graphs showing interquartile range of daily flows for streamgage stations along the main-stem Missouri River............................................................................................5

4. Box plots showing annual runoff for streamgage stations on the Yellowstone, Upper Missouri, and Lower Missouri Rivers................................................................

5. Hydrographs and thermographs for 2005-13, Yellowstone and Upper Missouri

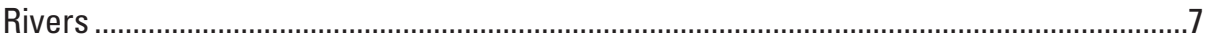

6. Hydrographs and thermographs for 2005-13, Lower Missouri River..............................10

7. Map showing study sections of the Comprehensive Sturgeon Research Project within the Lower Missouri River

8. Graph showing telemetry locations of female pallid sturgeon PLS08-035; Missouri River temperature recorded from the nearest streamgage at Leavenworth, Kansas; Missouri River discharge recorded from the nearest streamgage at Kansas City, Missouri.

9. Graph showing telemetry locations of female pallid sturgeon PLS11-004; depth and temperature recorded from data storage tag; Missouri River temperature from the nearest streamgage at Lexington, Missouri; Missouri River discharge from the nearest streamgage at Glasgow, Missouri

10. Graph showing telemetry locations of female pallid sturgeon PLS11-016; depth and temperature recorded from data storage tag; Missouri River temperature from nearest streamgage at Omaha, Nebraska; Missouri River discharge from the nearest streamgage at Nebraska City, Nebraska; Platte River temperature from the nearest streamgage at Louisville, Nebraska...

11. Graph showing telemetry locations of female pallid sturgeon PLS11-017; depth and temperature recorded from data storage tag; Missouri River discharge and temperature from the nearest streamgage at Omaha, Nebraska; Platte River temperature from the nearest streamgage at Louisville, Nebraska.

12. Graph showing telemetry locations of female pallid sturgeon PLS11-018; depth and temperature recorded from data storage tag; Missouri River temperature from the nearest streamgage at Omaha, Nebraska; Missouri River discharge from the nearest streamgage at Rulo, Nebraska; Platte River temperature from the nearest streamgage at Louisville, Nebraska. 
13. Graph showing telemetry locations of female pallid sturgeon PLS11-020; depth and temperature recorded from data storage tag; Missouri River temperature from the nearest streamgage at Omaha, Nebraska; Missouri River discharge from the nearest streamgage at Nebraska City, Nebraska; Platte River temperature from the nearest streamgage at Louisville, Nebraska

14. Graph showing telemetry locations of female pallid sturgeon PLS13-001, depth and temperature recorded from data storage tag; Missouri River temperature and discharge from the nearest streamgage at Kansas City, Missouri. 22

15. Graph showing telemetry locations of female pallid sturgeon PLS13-003; depth and temperature recorded from data storage tag; Missouri River temperature and discharge from the nearest streamgage at Omaha, Nebraska.

16. Graph showing telemetry locations of male pallid sturgeon PLS13-002; Missouri River temperature from the nearest streamgage at Lexington, Missouri; Missouri River discharge from the nearest streamgage at Kansas City, Missouri..

17. Map showing locations of spawning sites used by telemetered pallid sturgeon in the Lower Missouri River, 2007-13

18. Bathymetric map showing site where pallid sturgeon PLS08-035 spawned on May 10-11, 2013. .30

19. Acoustic Doppler current profiler velocity map showing site where pallid sturgeon PLS08-035 spawned on May 10-11, 2013. .31

20. Bathymetric map showing site where pallid sturgeon PLS13-001 spawned on May 10-11, 2013

21. Acoustic Doppler current profiler velocity map showing site where pallid sturgeon PLS13-001 spawned on May 10-11, 2013.

22. Bathymetric map showing site where pallid sturgeon PLS13-003 spawned on May 12-13, 2013.

23. Acoustic Doppler current profiler velocity map showing site where pallid sturgeon PLS13-003 spawned on May 12-13, 2013.

24. Map showing velocities, collected with an acoustic Doppler current profiler, in side chute used by migrating reproductive pallid sturgeon PLS11-004 on April 12, 2013.

25. Maps showing free-embryo sampling locations in the Lower Missouri River and the Platte River

26. Maps showing depth and velocity for free embryo and larval sampling transect in the Missouri River near river mile 599.5

27. Maps showing depth and velocity for free embryo and larval sampling transect in the Platte River.

28. Graph showing length of sturgeon free embryos and larvae collected at the Missouri River site during 2013

29. Graph showing length of sturgeon free embryos and larvae collected at the Platte River site during 2013

30. Graph showing length of paddlefish free embryos and larvae collected the Missouri River site during 2013

31. Diagram showing the Sturgeon Information Management System that accommodates and integrates multiple disparate data types by using a suite of software to accommodate various data formats and the demand for near real-time updates

32. Graph showing mean daily discharge and water temperature for the Yellowstone River in 2013 
33. Graph showing percent of telemetered pallid sturgeon in the Yellowstone River by date, and corresponding mean daily discharge and water temperature for the Yellowstone River in 2013

34. Graphs showing locations of seven telemetered pallid sturgeon migrating to Intake Diversion by date and discharge, and dates of residency of pallid sturgeon at Intake Dam in 2013.

35. Graphs showing locations of telemetered female pallid sturgeon code 41 and code 40 in the Yellowstone River and Missouri River during 2013. . .60

36. Bathymetric and acoustic Doppler current profiler maps showing site where pallid sturgeon spawning was documented in 2013

37. Bathymetric and acoustic Doppler current profiler maps showing site where pallid sturgeon are suspected to have spawned in 2011

38. Bathymetric and acoustic Doppler current profiler maps showing site where male pallid sturgeon aggregation was documented from June 10,2013 , to June 13, 2013

39. Bathymetric and acoustic Doppler current profiler maps showing site where male pallid sturgeon aggregation was documented from June 7, 2013, to June 21, 2013

40. Bathymetric and acoustic Doppler current profiler maps showing site where male pallid sturgeon aggregation was documented from June 7, 2013, to June 21, 2013

41. Map showing velocities, collected with an acoustic Doppler current profiler, along migration pathway used by reproductive female code 41 on June 12, 2013

42. Map showing velocities, collected with an acoustic Doppler current profiler, along a second migration pathway used by reproductive female code 41 on June 12, 2013

43. Map showing velocities, collected with an acoustic Doppler current profiler, along migration pathway used by reproductive female radio 41 on June 19 , 2013

44. Bathymetric and acoustic Doppler current profiler maps showing sampling sites for Acipenseriformes free embryos and larvae on the Yellowstone River in 2013 .........73

45. Map showing the study area of the Missouri River, Milk River and Lower Yellowstone River

46. Graph showing mean daily discharge in the Missouri River at Culbertson, Montana, Missouri River at Wolf Point, Montana, and in the Milk River at Nashua, Montana, during 2013

47. Graph showing temperature at Nickels, Wolf Point, and Nohly in the Missouri River, Milk River and Yellowstone River during 2013

48. Graph showing percentage of telemetered adult pallid sturgeon located in the Missouri River above the confluence of the Yellowstone River by date from 2005 to 2013

49. Graph showing locations of 29 different telemetered pallid sturgeon that used the Missouri River above the Yellowstone River confluence in 2013

50. Schematic diagram showing experimental flume system used for dispersal studies with early life stage pallid sturgeon

51. Graph showing cumulative percent mortality of different age pallid sturgeon embryos in relation to drift duration in the flume system for experiment 1

52. Graph showing cumulative percent mortality of different age pallid sturgeon embryos in relation to drift duration in the flume system for experiment 2 


\section{Tables}

1. Probable spawning locations of telemetry tracked reproductive female pallid

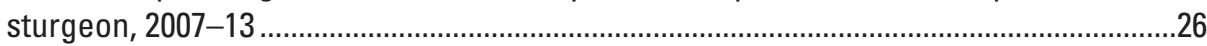

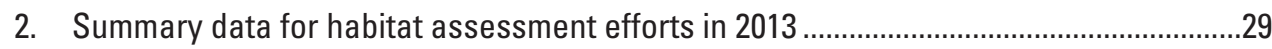

3. Summary data for mapping of 2013 free embryo and larvae sampling sites....................37

4. Sampling period, number of sampling days, mean water volume sampled, number and density of sturgeon and paddlefish free embryos and larvae collected during 2013.

5. Number, mean length, minimum length, maximum length of free-embryo and larval sturgeon and paddlefish collected in the Missouri River at station 10

6. Number, mean length, minimum length, maximum length of free-embryo and larval sturgeon and paddlefish collected in the Missouri River at station 11.

7. Number, mean length, minimum length, maximum length of free-embryo and larval sturgeon and paddlefish collected in the Missouri River at station 12

8. Number, mean length, minimum length, maximum length of free-embryo and larval sturgeon and paddlefish collected in the Missouri River at station 13

9. Number, mean length, minimum length, maximum length of free-embryo and larval sturgeon and paddlefish collected in the Platte River at station 14.

10. Number, mean length, minimum length, maximum length of free-embryo and larval sturgeon and paddlefish collected in the Platte River at station 15.

11. Number, mean length, minimum length, maximum length of free-embryo and larval sturgeon and paddlefish collected in the Platte River at station 16.

12. Mean density, number per 100 cubic meters, of sturgeon free embryos and larvae per sampling day

13. Mean density, number per 100 cubic meters, of paddlefish free embryos and larvae per sampling day.

14. Dates and collections of Acipenseriformes early life stages sampled from the Yellowstone River, 2013.

15. Summary data for habitat assessment efforts in 2013

16. Summary table for measurements made in $\mathbf{2 0 1 3}$ specifically for dispersion calculations

17. Number and percent telemetry locations recorded in the Upper Missouri and Yellowstone Rivers per month during 2013.

18. Sampling dates and paddlefish free embryos collected in the Milk River in 2013 ...........79

19. Sampling dates and paddlefish and sturgeon free embryos collected in the Missouri River near Wolf Point in 2013.

20. Total catch of fish by the benthic trawl in the Missouri River above the confluence of the Yellowstone River, Missouri River below the confluence of the Yellowstone River, and total catch from July 31 to September 4, 2013

21. Number of young-of-year shovelnose sturgeon collected in standard trawls, targeted trawls, minimum length, maximum length, and mean length in 2013 by date

22. Water quality measured in culture units, flume, and blending tanks .88

23. Age, daily cumulative temperature units, development, and growth metrics of pallid sturgeon lots PLS-2 and PLS-4 used in experiments 1 and 2 


\section{Conversion Factors}

[Inch/Pound to International System of Units]

\begin{tabular}{|c|c|c|}
\hline Multiply & By & To obtain \\
\hline \multicolumn{3}{|c|}{ Length } \\
\hline micrometer $(\mu \mathrm{m})$ & 0.0000397 & inch (in.) \\
\hline millimeter $(\mathrm{mm})$ & 0.03937 & inch (in.) \\
\hline centimeter $(\mathrm{cm})$ & 0.3937 & inch (in.) \\
\hline meter $(\mathrm{m})$ & 3.281 & foot $(\mathrm{ft})$ \\
\hline kilometer (km) & 0.6214 & mile (mi) \\
\hline meter $(\mathrm{m})$ & 1.094 & yard (yd) \\
\hline \multicolumn{3}{|c|}{ Area } \\
\hline square meter $\left(\mathrm{m}^{2}\right)$ & 10.76 & square foot $\left(\mathrm{ft}^{2}\right)$ \\
\hline hectare (ha) & 0.003861 & square mile $\left(\mathrm{mi}^{2}\right)$ \\
\hline square kilometer $\left(\mathrm{km}^{2}\right)$ & 0.3861 & square mile $\left(\mathrm{mi}^{2}\right)$ \\
\hline \multicolumn{3}{|c|}{ Volume } \\
\hline cubic meter $\left(\mathrm{m}^{3}\right)$ & 264.2 & gallon (gal) \\
\hline cubic meter $\left(\mathrm{m}^{3}\right)$ & 35.31 & cubic foot $\left(\mathrm{ft}^{3}\right)$ \\
\hline cubic meter $\left(\mathrm{m}^{3}\right)$ & 1.308 & cubic yard $\left(\mathrm{yd}^{3}\right)$ \\
\hline \multicolumn{3}{|c|}{ Flow rate } \\
\hline meter per second (m/s) & 3.281 & foot per second $(\mathrm{ft} / \mathrm{s})$ \\
\hline cubic meter per second $\left(\mathrm{m}^{3} / \mathrm{s}\right)$ & 35.31 & cubic foot per second $\left(\mathrm{ft}^{3} / \mathrm{s}\right)$ \\
\hline \multicolumn{3}{|c|}{ Mass } \\
\hline $\operatorname{gram}(\mathrm{g})$ & 0.03527 & ounce, avoirdupois (oz) \\
\hline kilogram (kg) & 2.205 & pound avoirdupois (lb) \\
\hline
\end{tabular}

To communicate effectively with stakeholders, managers, and other scientists working on the Lower Missouri River, this report uses a mix of U.S. customary units and International System of Units (SI) units of measure. Distances along the Missouri River are given in river miles upstream from the confluence with the Mississippi River at St. Louis, Missouri, as measured by the U.S. Army Corps of Engineers in 1960. Discharges are provided in the customary units of cubic feet per second. Reach-scale hydraulic variables_-depth and velocity-are in SI units of meters and meters per second.

Temperature in degrees Celsius $\left({ }^{\circ} \mathrm{C}\right)$ may be converted to degrees Fahrenheit $\left({ }^{\circ} \mathrm{F}\right)$ as follows:

${ }^{\circ} \mathrm{F}=\left(1.8 x^{\circ} \mathrm{C}\right)+32$

Vertical coordinate information is referenced to the North American Vertical Datum of 1988 (NAVD 88)

Horizontal coordinate information is referenced to the World Geodetic System of 1984 (WGS 84) 



\title{
Ecological Requirements for Pallid Sturgeon Reproduction and Recruitment in the Missouri River-Annual Report 2013
}

\author{
By Aaron J. DeLonay, ${ }^{1}$ Robert B. Jacobson, ${ }^{1}$ Kimberly A. Chojnacki, ${ }^{1}$ Patrick J. Braaten, ${ }^{1}$ Kevin J. Buhl, ${ }^{1}$ \\ Brandon L. Eder, ${ }^{2}$ Caroline M. Elliott, ${ }^{1}$ Susannah O. Erwin, ${ }^{1}$ David B. Fuller, ${ }^{3}$ Tyler M. Haddix, ${ }^{3}$ Hallie L.A. Ladd, ${ }^{4}$ \\ Gerald E. Mestl, ${ }^{2}$ Diana M. Papoulias, ${ }^{1}$ Jason C. Rhoten, ${ }^{3}$ Christopher J. Wesolek, ${ }^{3}$ and Mark. L. Wildhaber ${ }^{1}$
}

Abstract

The Comprehensive Sturgeon Research Project is a multiyear, multiagency collaborative research framework developed to provide information to support pallid sturgeon recovery and Missouri River management decisions. The project strategy integrates field and laboratory studies of pallid sturgeon reproductive ecology, early life history, habitat requirements, and physiology. The project scope of work is developed annually with collaborating research partners and in cooperation with the U.S. Army Corps of Engineers, Missouri River Recovery-Integrated Science Program. The research consists of several interdependent and complementary tasks that engage multiple disciplines.

The research tasks in the 2013 scope of work emphasized understanding reproductive migrations and spawning of adult pallid sturgeon, and hatch and drift of free embryos and larvae. These tasks were addressed in four study sections located in three hydrologically and geomorphologically distinct parts of the Missouri River Basin: the Upper Missouri River downstream from Fort Peck Dam, including downstream reaches of the Milk River, the Lower Yellowstone River, and the Lower Missouri River downstream from Gavins Point Dam. The research is designed to inform management decisions related to channel re-engineering, flow modification, and pallid sturgeon population augmentation on the Missouri River, and throughout the range of the species. Research and progress made through this project are reported to the U.S. Army Corps of Engineers annually. This annual report details the research effort and progress made by the Comprehensive Sturgeon Research Project during 2013.

\footnotetext{
${ }^{1}$ U.S. Geological Survey

${ }^{2}$ Nebraska Game and Parks Commission

${ }^{3}$ Montana Fish, Wildlife and Parks

${ }^{4}$ Five Rivers Services, LLC
}

\section{Introduction}

This report documents research activities for the Comprehensive Sturgeon Research Project (CSRP) for calendar year 2013. The CSRP is an interagency collaboration of the U.S. Geological Survey (USGS), Nebraska Game and Parks Commission (NGPC), U.S. Fish and Wildlife Service (USFWS), Montana Fish Wildlife and Parks (MWFP) and is funded through the U.S. Army Corps of Engineers' (USACE) Missouri River Recovery-Integrated Science Program. The goal of the CSRP is to improve the fundamental understanding of the reproductive ecology of the pallid sturgeon (Scaphirhynchus albus) to better inform river- and species-management decisions. Specific objectives include the following:

- Determine movement, habitat use, and reproductive behavior of pallid sturgeon; understand reproductive physiology of pallid sturgeon and relations to environmental conditions;

- Determine origin, transport, and fate of drifting pallid sturgeon free embryos and evaluate bottlenecks for recruitment of early life stages;

- Quantify availability and dynamics of aquatic habitats needed by pallid sturgeon for all life stages; and

- Manage databases, integrate understanding, and publish information relevant to management decisions into the public domain.

Management actions to increase reproductive success and survival of pallid sturgeon in the Missouri River have been focused on re-naturalizing the flow regime, re-engineering channel morphology, and augmenting populations through artificial propagation (U.S. Fish and Wildlife Service, 2003). Since 2005, scientists at the U.S. Geological Survey Columbia Environmental Research Center (CERC) and partner agencies have engaged in interdisciplinary research to provide fundamental information necessary to understand linkages between management actions and sturgeon responses. 
The CSRP direction has been guided by results of sturgeon research workshops convened in 2004 (Quist and others, 2004) and 2007 (Bergman and others, 2008), by hypotheses that emerged about the role of a naturalized flow regime in pallid sturgeon reproduction during a series of workshops in 2005 (Jacobson and Galat, 2008), by feedback from an independent science review (Sustainable Ecosystems Institute, 2008), and by a recent independent science panel review of spring pulses (Doyle and others, 2011). Research objectives have emphasized science information gaps related to priority management issues, including understanding of the role of pulsed flow releases from Gavins Point Dam and Fort Peck Dam (fig. 1), and understanding of the functions of constructed shallow-water habitat in sturgeon recruitment.

Our research priorities have been guided by a conceptual model of pallid sturgeon biology (Wildhaber and others, 2007a, 2011a) and an understanding of how the fish uses the river spatially for different life stages (fig. 2). Priority has been placed sequentially on reproductive adults and spawning, followed by early life stages, because these are the life stages considered to be most influential in increasing and sustaining sturgeon populations (Bajer and Wildhaber, 2007).

The CSRP approach integrates field-based experiments and controlled laboratory studies. Field studies are designed to explore the roles of flow regime, channel configuration, and environmental cues in sturgeon reproduction and recruitment. The project uses an upstream-downstream experimental design to compare sturgeon reproductive behavior among four study sections with different hydrologic regimes within the Missouri River system. Variation in channel morphology from near natural conditions in the Upper Missouri and Yellowstone River study sections to channelized and variably restored conditions in the upper and lower study sections of the Lower Missouri River allow for evaluation of how channel form relates to spawning, dispersal, and rearing.

The Yellowstone River provides a nearly unaltered flow regime and channel morphology (DeLonay and others, 2016) that is natural and complex, with the exception of a weir that presumably limits fish passage at approximately 70 miles upstream from the confluence of the Yellowstone and Missouri Rivers near Glendive, Montana (not shown). The Upper Missouri River has a highly altered flow and temperature regime (fig. 3) because of its location downstream from Fort Peck Dam, and a natural and complex channel morphology. The Upper Missouri River also offers the opportunity to evaluate sturgeon selection of the Milk River, a tributary with high temperature and increased turbidity relative to that available in the main-stem Upper Missouri River.

The Lower Missouri River includes an upstream and downstream study section. The upstream section of the Lower Missouri River has a highly altered flow regime (fig. 3) and channel morphology that varies between a nonchannelized portion from Gavins Point Dam downstream to the Big Sioux River confluence and a narrow channelized portion from the Big Sioux River downstream to the Platte River (DeLonay and others, 2016). The upstream section also has the potential for experimental flow treatments from Gavins Point Dam that can be used for more controlled comparisons of reproductive behavior in years with pulsed flow modifications ("spring rises") to years without pulsed flow modifications. The lower study section of the Lower Missouri River has a flow regime that has recovered some of the natural variability as a result of tributary effects (fig. 3), thereby providing flow pulses in most years. This section also has been channelized, but it has greater width and somewhat greater complexity compared to the upper study section downstream from the Big Sioux River (DeLonay and others, 2016).

Field studies of pallid sturgeon migration, spawning, and dispersal are complemented with controlled laboratory studies that seek to provide more precise understanding under controlled conditions. During 2013, laboratory studies focused on hatch and free-embryo drift behaviors. Designing laboratory experiments that provide for adequate survival of early life stage sturgeon while approximating realistic environmental conditions likely to be experienced by hatching and drifting sturgeon pose a substantial challenge. Understanding the effects of environmental factors on hatch success and the role of ontogenic changes in drift behavior and dispersal are critical for assessing factors limiting survival at these early life stages.

\section{Comprehensive Sturgeon Research Project 2013 Scope of Work}

The 2013 Scope of Work was developed around six coordinated tasks.

- Task 1. Movement, habitat use and reproductive behavior of pallid sturgeon in the Lower Missouri River

- Task 1 is carried out in coordination with Nebraska Game and Parks Commission and has four components addressing reproductive ecology/movements, habitat dynamics, free-embryo drift, and data management.

- Task 2. Reproduction, habitat use, and early life stage dynamics of pallid sturgeon in the Yellowstone River

- Task 2 is carried out in coordination with Montana Fish Wildlife and Parks and has three components addressing migration and reproduction, habitat dynamics, and data management.

- Task 3. Examination of pallid sturgeon use, migrations and spawning in the Milk River and Missouri River below Fort Peck Dam

- Task 3 is carried out by Montana Fish Wildlife and Parks and addresses ecology/movements and integrative free-embryo drift. 


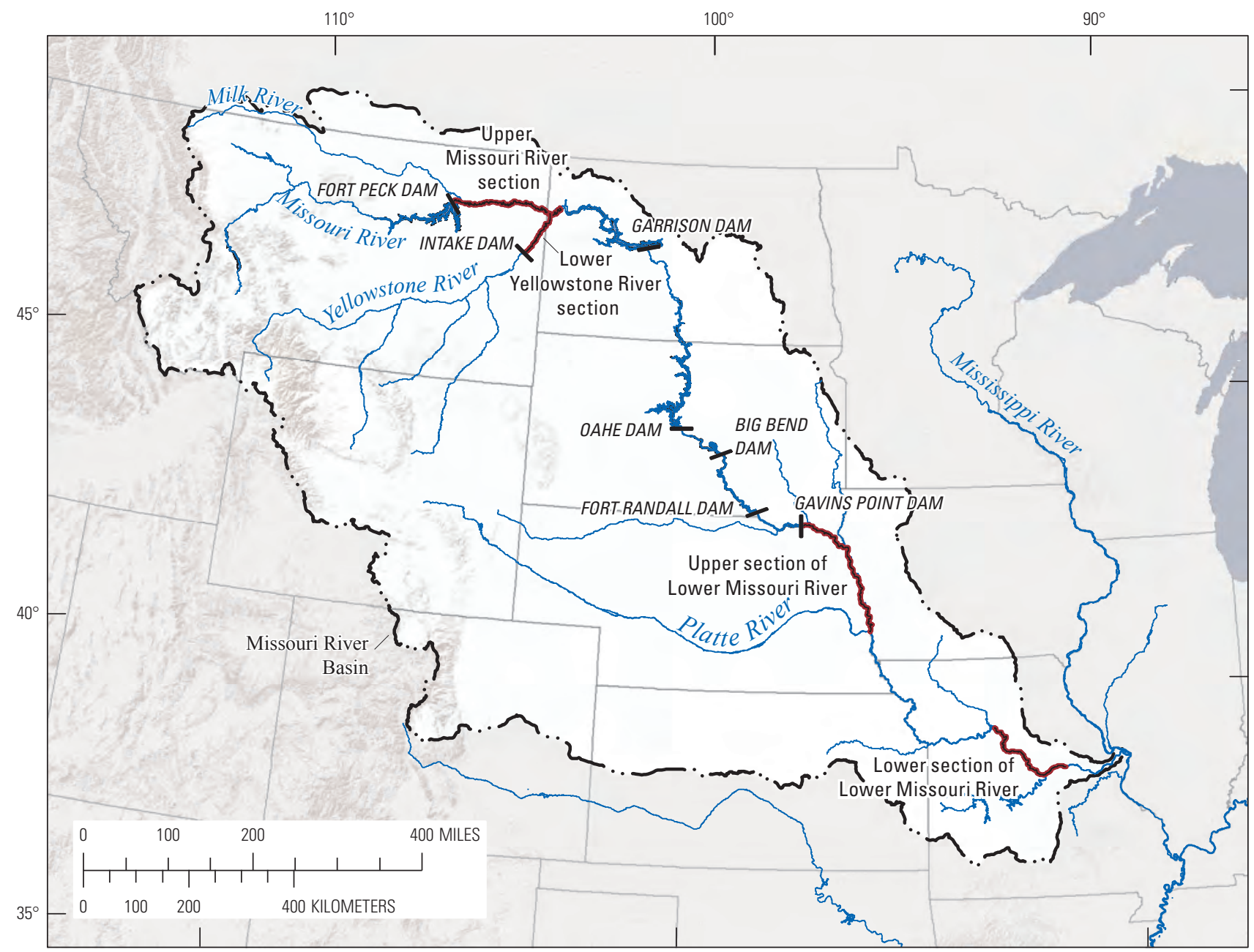

Base from U.S. Geological Survey digital data, 2002, 1:2,000,000 Albers Equal-Area Conic projection

Figure 1. Missouri River Basin and major tributary rivers with the Comprehensive Sturgeon Research Project study areas.

- Task 4. Assessment of male sturgeon reproductive biology and indicators of successful spawning, Lower Missouri River.

- Task 4 has been re-scoped with indicators of reproductive status and successful spawning developed in previous years under the CSRP and is presently (2013) integrated with studies of reproductive ecology under Tasks 1-3. Specific assessments of male reproductive biology previously included in our scope of work were dependent on the opportunistic availability of samples from males in near spawning condition. Samples were not available and progress under Task 4 is not presented separately in this report.

- Task 5. Missouri River Pallid Sturgeon Population Assessment Program synthesis towards understanding population trends of pallid sturgeon and other targeted species
- Task 5 builds on past and current assessments and syntheses of data from the CSRP and the Pallid Sturgeon Population Assessment Program (PSPAP). Task 5 includes studies estimating relative abundance, evaluating the effects of tag loss on abundance estimates, and synthesis of a population viability model. Laboratory studies designed to inform spatiallyexplicit aspects of submodels within the population model also are included.

- Task 6. Hatching and drift of pallid sturgeon free embryos and starvation of larvae in laboratory studies at near field environmental conditions

- Task 6 is an experimental approach to understanding normal pallid sturgeon behaviors from hatch through first-feeding. This research involves direct laboratory observations and quantification of stage-specific vertical and horizontal movements and passive and active downstream migration of larvae to understand factors that may affect drift, retention, and survival. 


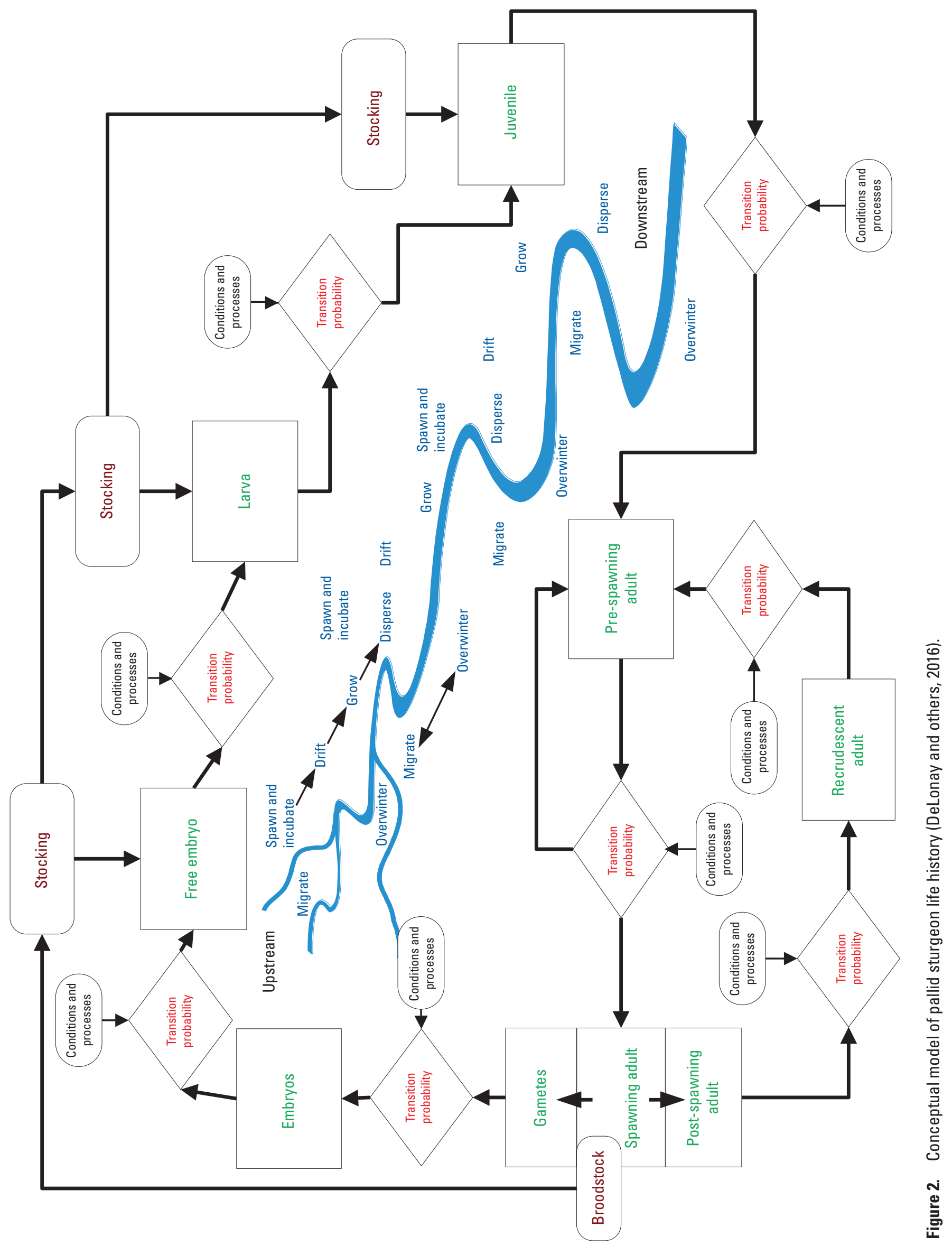



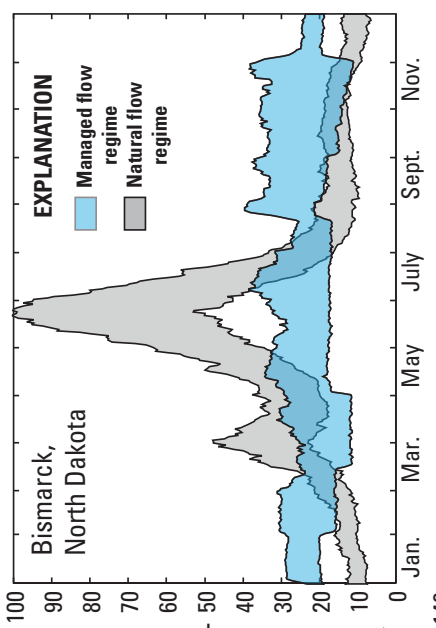

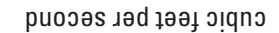
to spuesnoył u! ‘әблецәs!
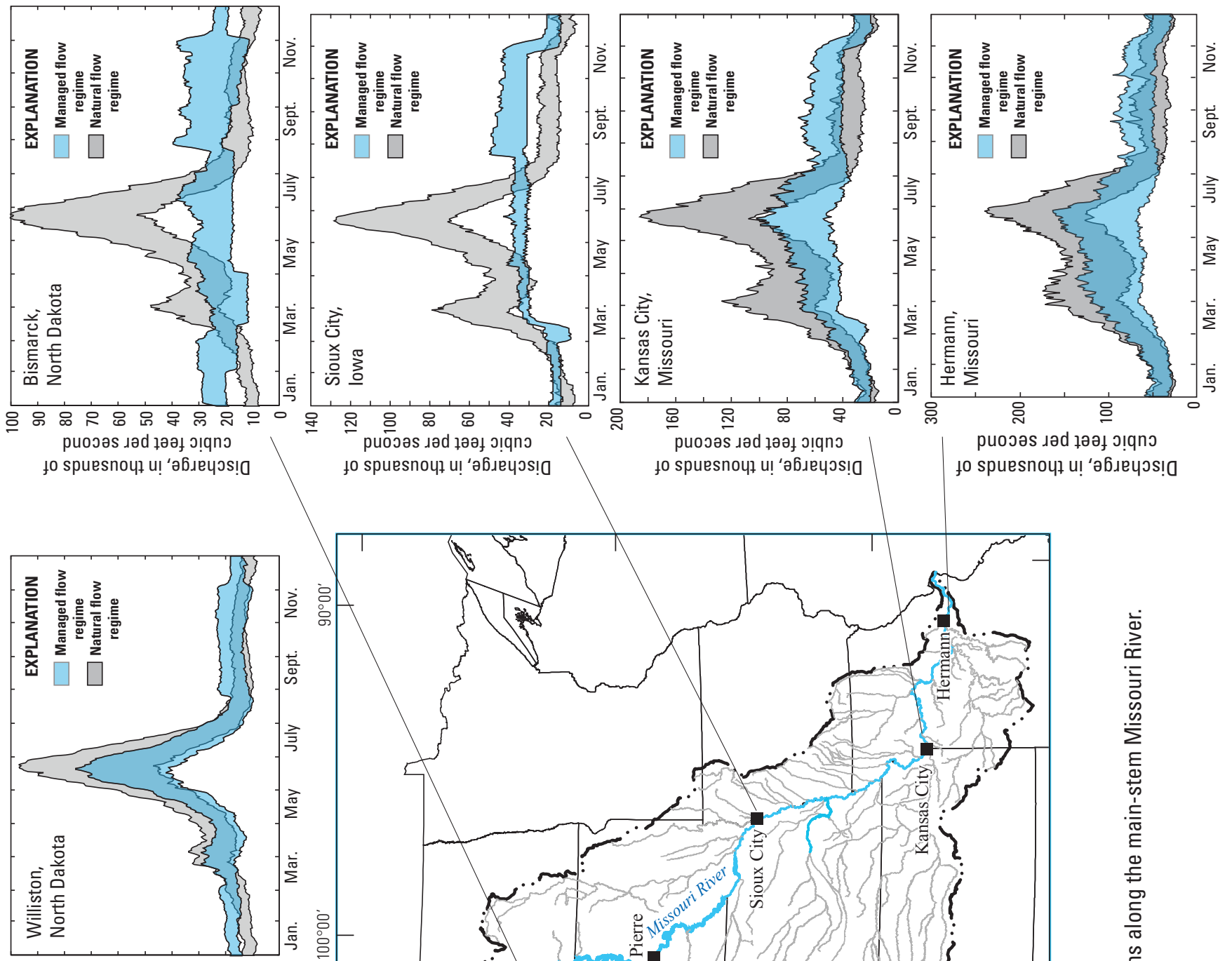

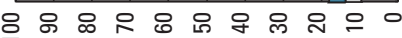

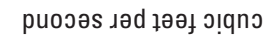
fo spuesnouł u! ‘ә6ıецวs!
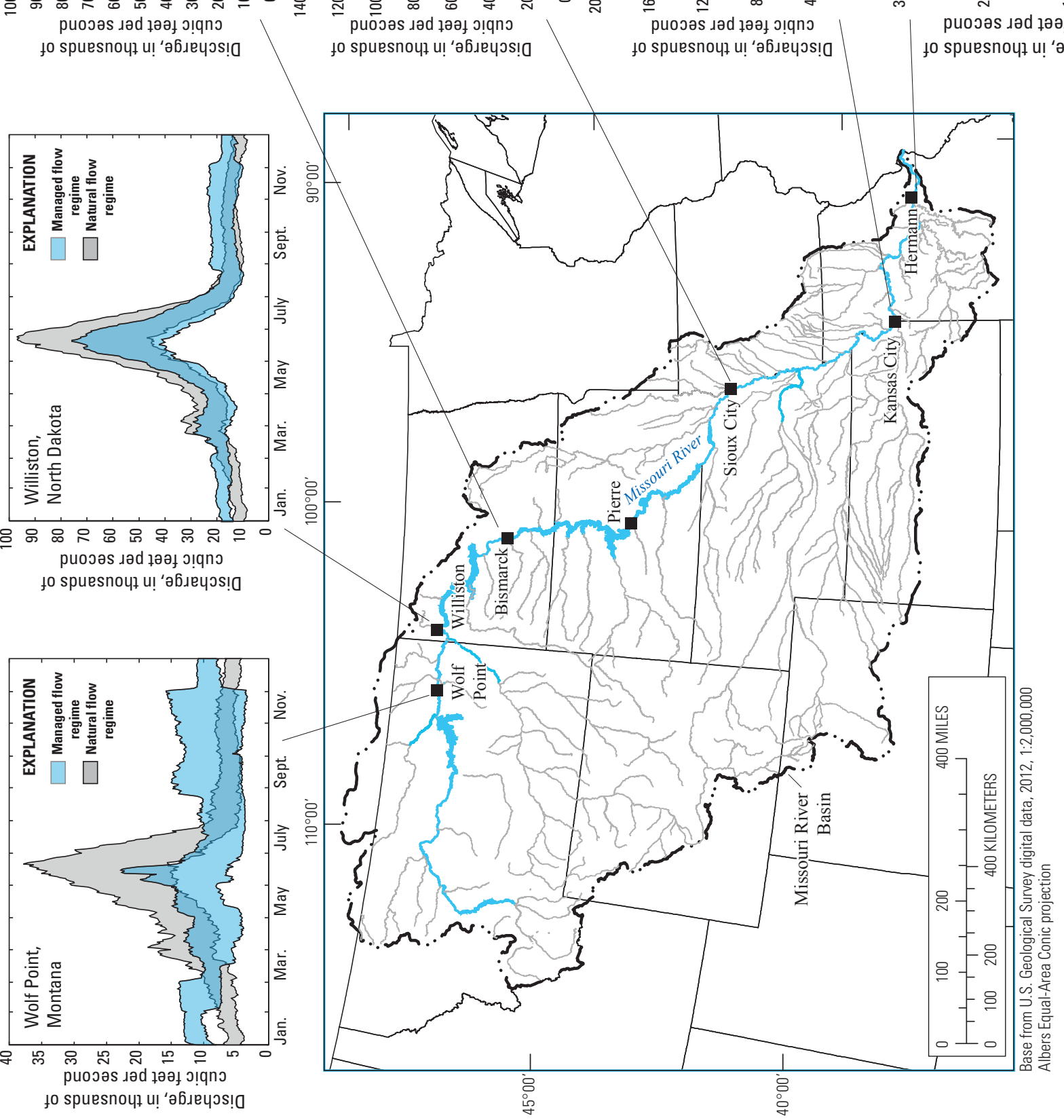

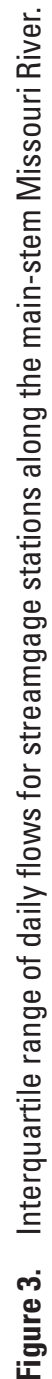




\section{Hydroclimatic Conditions During 2013}

Hydroclimatic conditions in the Missouri River Basin were dry in 2013 (fig. 4). Runoff values in the Yellowstone and Upper Missouri River were near median, as calculated for the period since 1967, but runoff in the Lower Missouri River was approximately equal to the 25 th percentile. Annual runoff in the Lower Missouri River upstream from Sioux City was 18.3 million acre-feet (maf) in 2013 just 2 years after the largest post-dam runoff on record of 57.3 maf in 2011.

Hydroclimatic conditions in 2013 provided another combination of environmental variability to the CSRP experimental framework for understanding the reproductive ecology of pallid sturgeon (figs. 5 and 6). Snowmelt flows started on the Lower Yellowstone River (fig. 1) in mid-May and peaked at 52,000 cubic feet per second $\left(\mathrm{ft}^{3} / \mathrm{s}\right)$ on June 1. A secondary snowmelt-flow peak followed on June 16-June 17, peaking at $37,000 \mathrm{ft}^{3} / \mathrm{s}$. Similar to most typical years on the Yellowstone River, discharge returned to base flow in late July (fig. 5). Water temperature on the Yellowstone River was highly variable compared to previous years. Superimposed on a seasonal increase, two substantial episodes of decreased temperature (greater than a 5 degree change) in mid-May and early June coincided with peaks in flow. Because this variation was mirrored on the Upper Missouri River, it is likely that the temperature excursions were associated with weather events rather than being controlled by flow variation. Water temperature on the Yellowstone River reached 16 degrees Celsius $\left({ }^{\circ} \mathrm{C}\right)$, considered to be a threshold temperature for pallid sturgeon spawning (DeLonay and others, 2016), on May 6, peaked at $19^{\circ} \mathrm{C}$ May 15 , but declined to $13{ }^{\circ} \mathrm{C}$ May 20 . Temperatures subsequently recovered to $19{ }^{\circ} \mathrm{C}$ on May 26 , followed by another decrease to $14{ }^{\circ} \mathrm{C}$ on June 1 . Temperatures rose back to $16{ }^{\circ} \mathrm{C}$ on June 6 and stayed above the value until instrument failure on August 31.

During June, the Upper Missouri River peaked at about $20,000 \mathrm{ft}^{3} / \mathrm{s}$ at Culbertson, Montana, because of an atypical flow pulse from June 7 to June 15. Flows during this period are usually stable and dominated by clear, cold water discharged from Fort Peck Dam. This pulse resulted from increased discharge from the Milk River rather than releases from Fort Peck Dam. Water temperatures on the Upper Missouri River were 1 to 4 degrees less than corresponding temperatures on the Yellowstone River, as is typical (DeLonay and others, 2016). The water temperature pattern mirrored that of the Yellowstone River and did not appear to be affected by the June flow pulse. Temperatures on the Upper Missouri River did not reach $16{ }^{\circ} \mathrm{C}$ until May 25; similar to the Yellowstone River, Missouri River temperatures also decreased precipitously to $12{ }^{\circ} \mathrm{C}$ on June 4 , and then recovered to remain above $16{ }^{\circ} \mathrm{C}$ on June 10 (fig. 5).

There was no intentional spring pulse-flow release from Gavins Point Dam on the Lower Missouri River in 2013 (fig. 6). Flows at Sioux City, Iowa, in the upper study section of the Lower Missouri River, were uniformly low. Normal navigation flows were interrupted only by a week-long pulse in late May that peaked at $40,000 \mathrm{ft}^{3} / \mathrm{s}$. Flows recorded downstream at Nebraska City, Nebraska, also were uniformly low

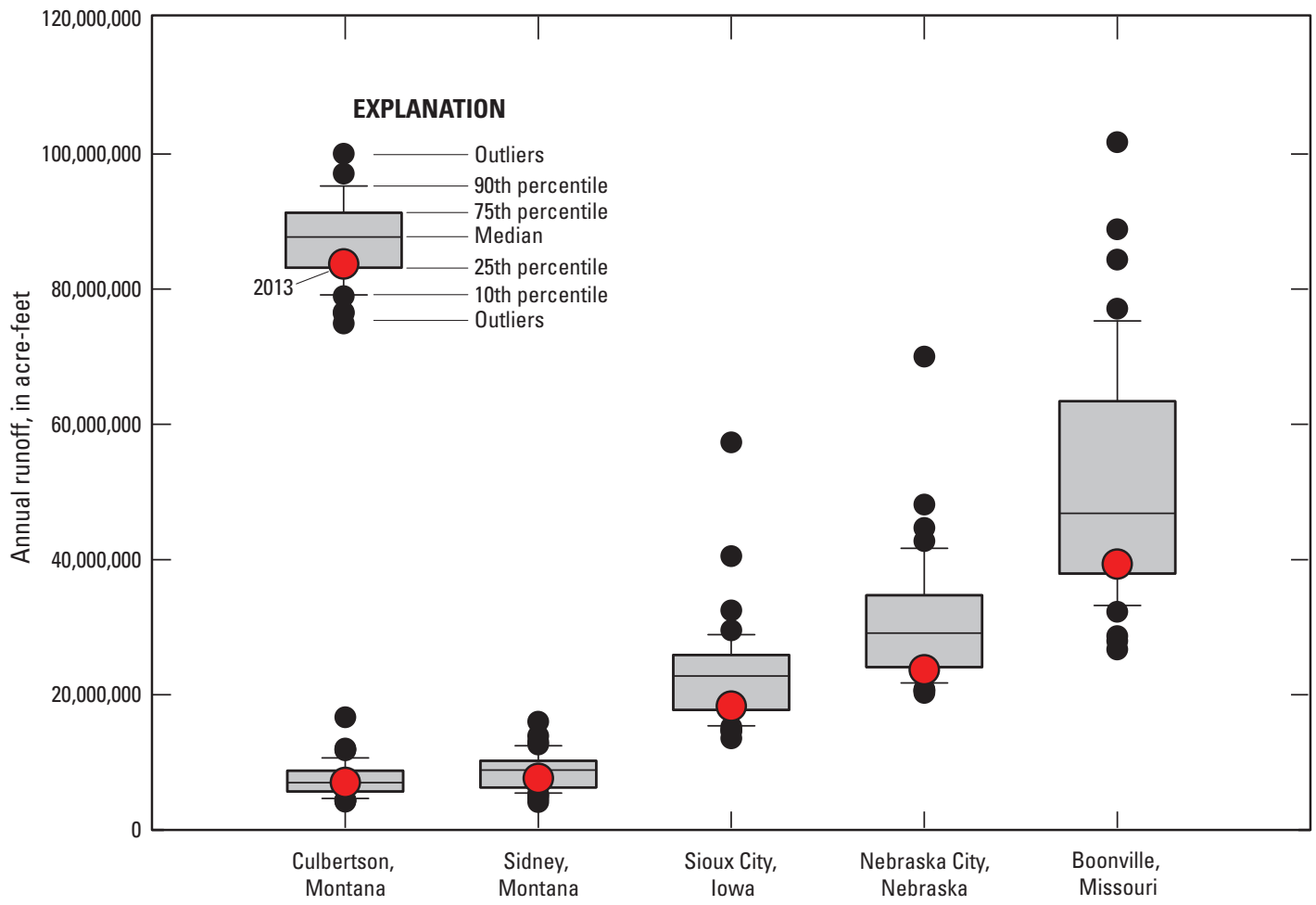

Figure 4. Box plots showing annual runoff for streamgage stations on the Yellowstone, Upper Missouri, and Lower Missouri Rivers. 


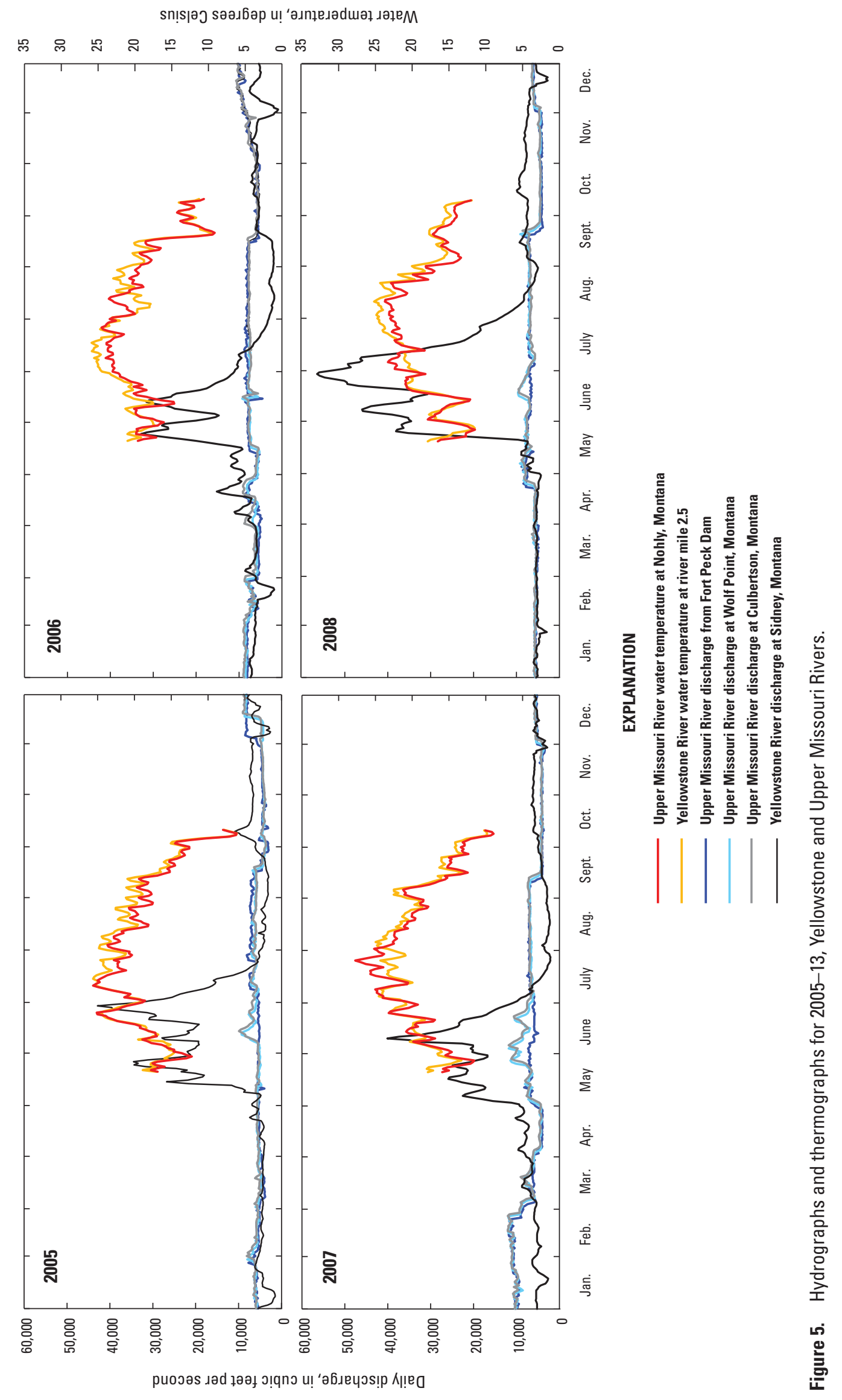




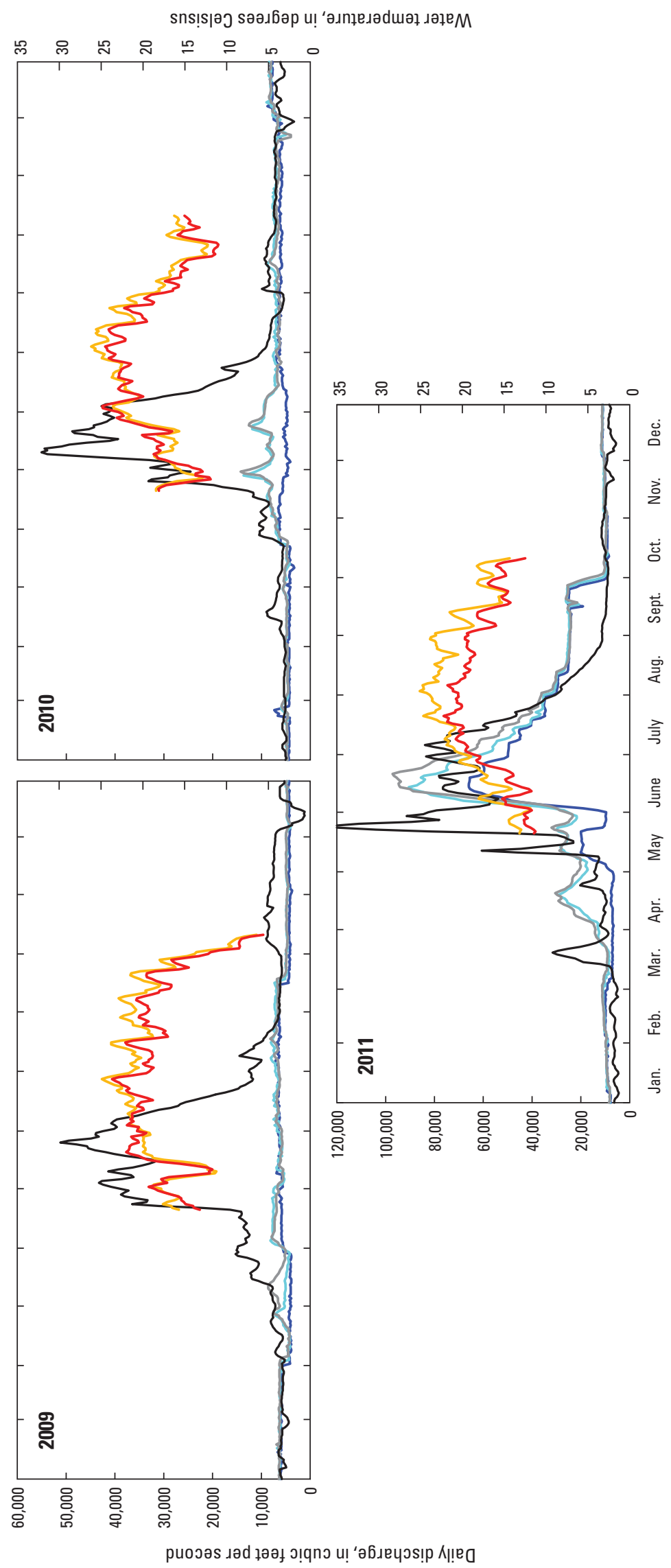

章 

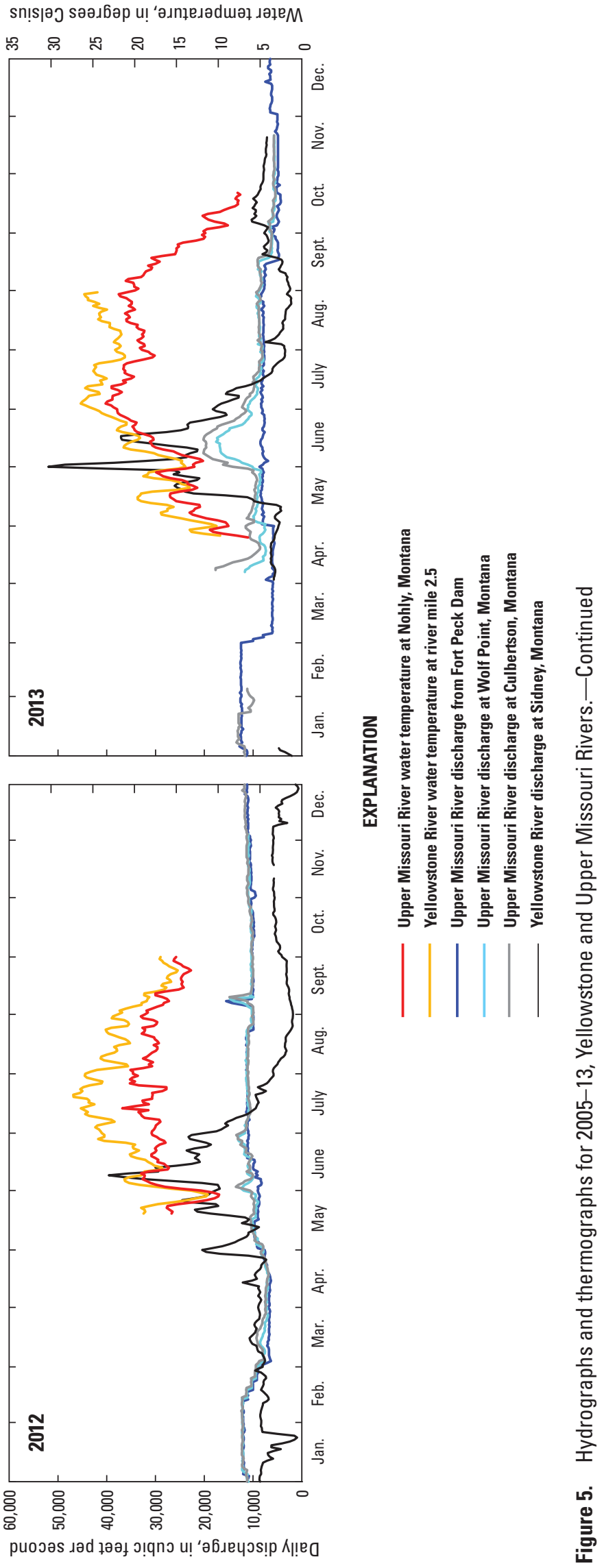


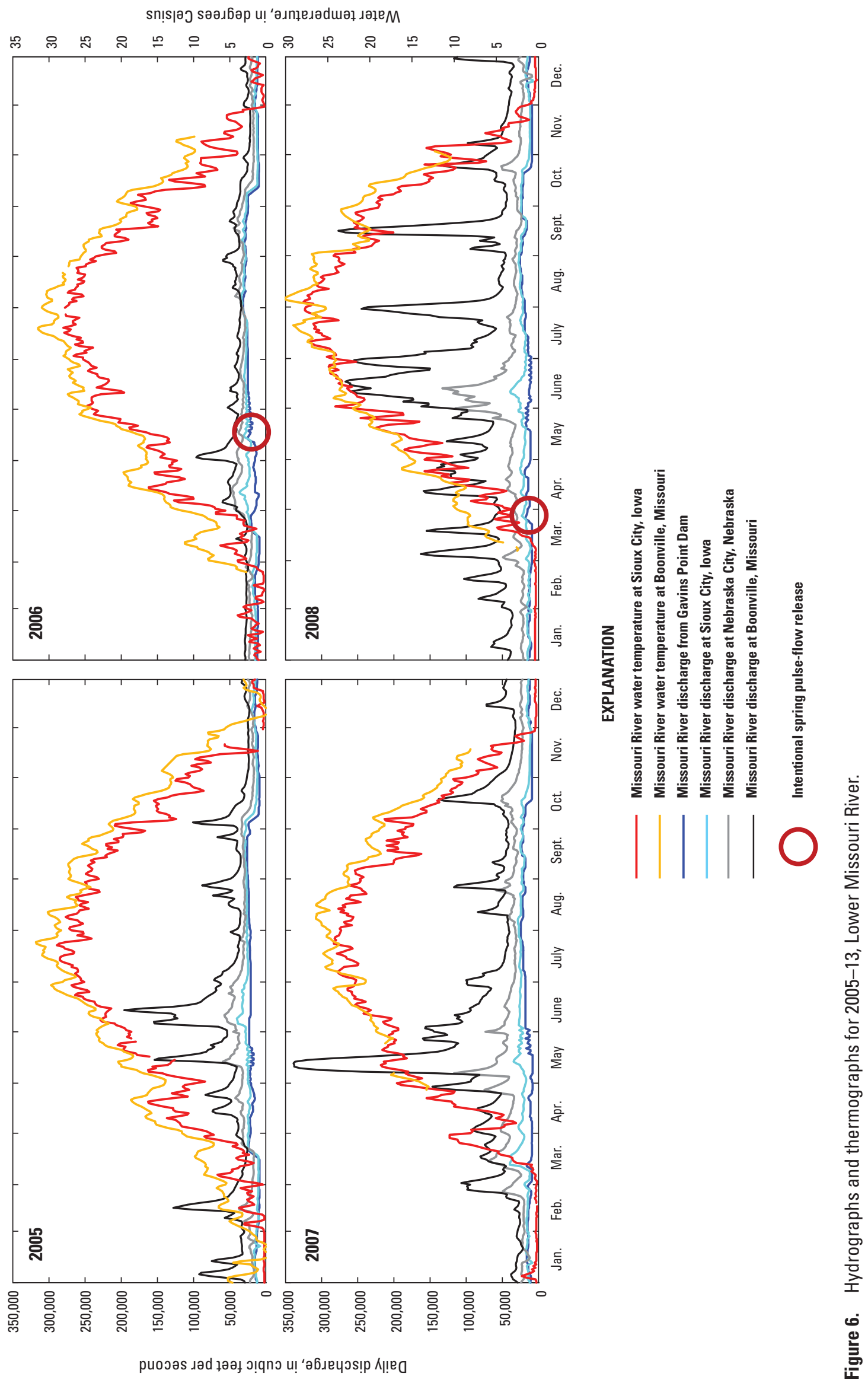




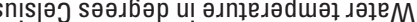
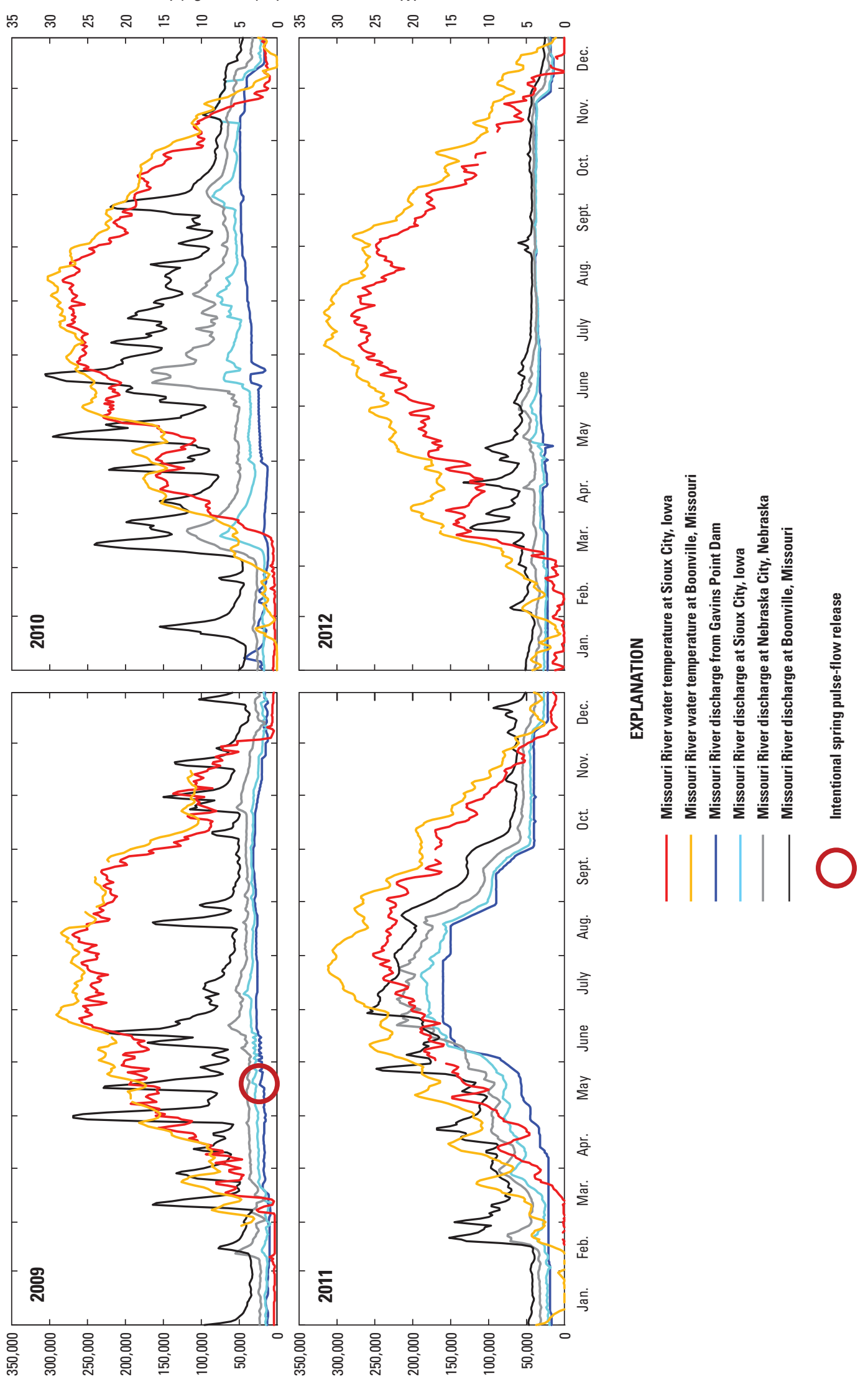

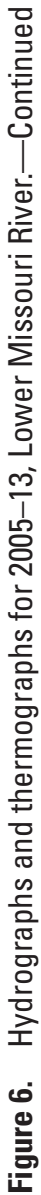




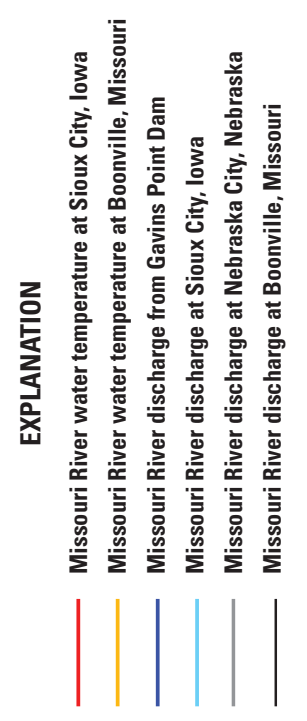

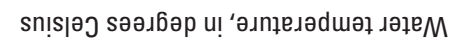

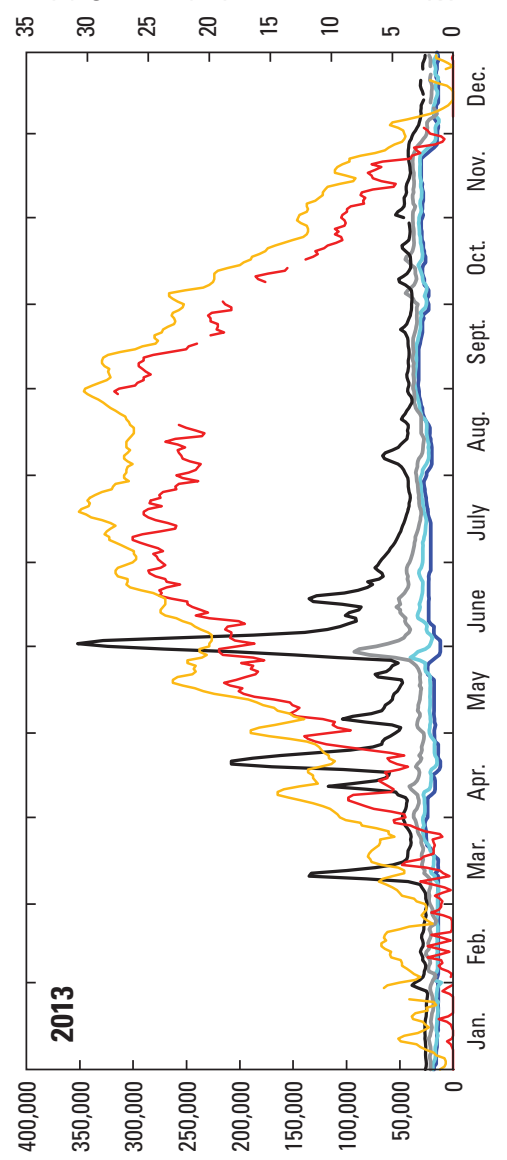

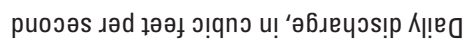

except for the late-May pulse that peaked at 93,000 $\mathrm{ft}^{3} / \mathrm{s}$. In contrast, the flow record at Boonville, Missouri, in the lower study section of the Lower Missouri River included a 135,000 $\mathrm{ft}^{3} / \mathrm{s}$ pulse in mid-March, a 208,000 $\mathrm{ft}^{3} / \mathrm{s}$ pulse on April 20-21, and substantial flood May 27-June 27 that peaked at 352,000 $\mathrm{ft}^{3} / \mathrm{s}$, or a flood with an approximately 10 percent annual likelihood of occurrence (U.S. Army Corps of Engineers, 2004).

Water temperature at Sioux City reached $16^{\circ} \mathrm{C}$ first on May 14 and stayed above $16{ }^{\circ} \mathrm{C}$ through September with the exception of a short excursion to $15.5^{\circ} \mathrm{C}$ on May 27. Water temperatures at Boonville, Missouri, reached $16{ }^{\circ} \mathrm{C}$ on April 30, decreased to $12{ }^{\circ} \mathrm{C}$ on May 5 , and then increased to $16^{\circ} \mathrm{C}$ on May 12 and remained above $16{ }^{\circ} \mathrm{C}$ until mid-October.

\section{Task 1. Movement, Habitat Use, and Reproduction of Pallid Sturgeon in the Lower Missouri River}

The decline of sturgeon populations is a global phenomenon (Secor and others, 2000). Habitat alteration, fragmentation, river regulation, pollution and over-harvest have resulted in the predictable patterns of decline and localized extirpation of sturgeon across species and geographic areas. Symptomatic of this generalized pattern of decline is poor reproductive success and low or no recruitment of juveniles to the adult population. The pallid sturgeon is no exception. Evidence of successful reproduction and survival of naturally spawned juvenile pallid sturgeon in the Lower Missouri River is limited. Pallid sturgeon remain rare and natural recruitment in the Lower Missouri River is insufficient to increase or sustain viable populations (U.S. Fish and Wildlife Service, 2007). Recent CSRP studies have documented spawning in the Lower Missouri River by wild and hatchery-origin pallid sturgeon (DeLonay and others, 2009; DeLonay and others, 2012; DeLonay and others, 2014). Despite evidence of recent spawning the factors or combination of factors limiting survival and recruitment of pallid sturgeon in the Lower Missouri River are unknown. In species recovery plans, and in several workshops, management agencies and scientists have consistently identified the need to (1) characterize and quantify spawning habitats; (2) develop a better understanding of environmental factors that affect maturation and spawning movements, including homing; (3) quantify spawning success and failure based on collections of eggs, larvae and young-ofyear; and (4) relate reproductive success to environmental conditions as priority information necessary to recover the species (U.S. Fish and Wildlife Service, 2007; Bergman and others, 2008). Task 1 is designed to document precisely where pallid sturgeon spawn and to provide information necessary to link pallid sturgeon migration, spawning, and reproductive success to large-river management in the Lower Missouri River.

The studies under this CSRP task combine telemetry observations with physiological assessments of reproductive 
behavior, hydroacoustic habitat assessments, hydraulic modeling, and free-embryo and larval sampling to develop a coordinated approach to examine the reproductive ecology of the pallid sturgeon in the Lower Missouri River (DeLonay and others, 2007; DeLonay and others, 2009; Papoulias and others, 2011). Telemetry is used to locate individual sturgeon over long periods to collect information on movement, habitat use, behavior, and response to environmental cues or habitat manipulations. Individual tagged sturgeon are repeatedly re-collected, re-assessed, and reimplanted to monitor changes in growth, condition, and reproductive status. Physiological assessments provide an understanding of the reproductive state of a tagged fish, and thereby provide information for the interpretation of fish behavior (Wildhaber and others, 2007b). Similarly, detailed habitat mapping around tagged fish locations places the behavior of individuals within a larger spatial context that allows researchers to characterize habitat availability and selection, and thereby understand how channel morphology and flow regime can be managed to maximize reproduction and survival (Reuter and others, 2008; DeLonay and others, 2009; Jacobson and others, 2009; Reuter and others, 2009; Bonnot and others, 2011). Identifying and characterizing spawning locations along the Lower Missouri River and in connected tributaries provide information necessary to direct studies and refine models of egg survival, hatch, and free-embryo dispersal.

Previous investigations under this task have resulted in the documentation of spawning by pallid sturgeon in the Lower Missouri River (DeLonay and others, 2009; DeLonay and others, 2012; DeLonay and others, 2014). Increasing numbers of observations of spawning adults over the course of the study have provided important insight into where, when, and under what conditions pallid sturgeon spawn. Observations of migration and spawning behavior have provided broad insight into the range of pallid sturgeon reproductive behaviors and the various conditions they can spawn under. Because of recent (2015) shifts in management focus by agencies and stakeholders, current research places less emphasis on the importance of environmental cues (Doyle and others, 2011). Rather continued studies focus efforts on determining if spawning is successful, and what conditions are conducive to survival and recruitment of juvenile pallid sturgeon. Evaluating sturgeon spawning success, whether or not developing embryos are hatching, and characterizing the patterns and extent of free-embryo drift and survival are critical to evaluating the effects of management actions on population growth and population parameters that promote recovery.

Although interrelated and complementary, pallid sturgeon studies under Task 1 in the Lower Missouri River are functionally separated into four subtasks to facilitate the presentation of progress and findings in 2013. Those subtasks include (1) movement, habitat use, and reproductive behavior of pallid sturgeon; (2) habitat use and availability during migration, spawning, and drift; (3) field studies of embryo, larvae, and young-of-year dispersal, distribution, and habitat use; and (4) data coordination, integration, geospatial analysis and outreach.

\section{Movement, Habitat Use, and Reproductive Behavior of Pallid Sturgeon}

Since 2004, the CSRP has used telemetry tagging and tracking methodologies to effectively locate individual sturgeon for several years and record data on movements, behavior, habitat use, and response to environmental cues or habitat manipulations (DeLonay and others, 2007; DeLonay and others, 2009; DeLonay and others, 2010; DeLonay and others, 2012). This multiyear research has provided opportunities to recapture, reassess and reimplant pallid sturgeon to monitor growth, condition, and changes in reproductive status through multiple years. Information gained through telemetry enhances the interpretation of data from sturgeon population and habitat monitoring programs on the Lower Missouri River that use traditional fisheries sampling techniques by sampling individual fish repeatedly, in all habitats, throughout all time periods. Telemetry data collected for multiple years provide a means for defining characteristic migration patterns of reproductive fish, identifying spawning locations, and detecting the patterns of habitat selection and spatial fidelity (DeLonay and others, 2007; DeLonay and others, 2009; DeLonay and others, 2012). Additionally, the CSRP has coupled telemetry transmitters with environmental data storage tags (DSTs) to provide unprecedented direct and quantitative data to assist in understanding the environment of individual pallid sturgeon (DeLonay and others, 2007; DeLonay and others, 2009). Telemetry, as a fisheries sampling technology, is central to the unique multidisciplinary approach of the CSRP in which sturgeon location and movement is coordinated with physiological assessments of reproductive behavior and hydroacoustic habitat assessments (DeLonay and others, 2009). Incorporation of the volumes of complex, multidisciplinary data into a single database system provides investigators the ability to explore the interrelationships among individuals and groups of tagged sturgeon over time across the landscape.

From 2006 to 2013, CSRP has emphasized tagging male and female sturgeon in reproductive condition to focus on identifying spawning cues, behaviors, and habitat. Generally, fish were captured in the late fall through spring, assessed for reproductive condition, and if reproductive, they were implanted with transmitters and tracked throughout the spring and summer. After a spawning migration or at the end of the season, the fish were targeted for recapture to extract DSTs and reimplant with long-lived telemetry tags. For the last 7 years, the approach has resulted in an at-large population of about 60-80 adult, male and female pallid sturgeon at various stages in the reproductive cycle.

The objectives of this work were to (1) identify prespawning habitat, (2) determine the direction and magnitude of spawning movements, (3) characterize patterns of habitat use during spawning migrations, (4) determine where and under what conditions sturgeon spawn, (5) verify and validate spawning behavior, (6) assess the relative success of spawning related to status and environmental conditions, including natural and augmented spring flows, and (7) determine and characterize post-spawn and nonreproductive habitat. 


\section{Methods}

As in previous years, capture and telemetry implantation efforts for this task were focused primarily within two geographically and hydrologically distinct reaches of the Lower Missouri River to take advantage of the longitudinal variability in the system for comparative purposes (fig. 7). Capture activities in the lower, downstream section were focused on the Lower Missouri River between the Osage River and Grand River (river miles 130-250). Capture activities in the upstream section were focused between the Platte River in Nebraska and the Big Sioux River (river miles 595-734). Once sturgeon were implanted with transmitters they were tracked throughout the Lower Missouri River, and were targeted for recapture and reimplantation wherever they were found.

Methods used in 2013 closely follow those developed and used by the CSRP during previous years (DeLonay and others, 2009; 2010; 2012). In 2013, the USGS and Nebraska Game and Parks Commission implanted and tracked female and male pallid sturgeon larger than two kilograms $(\mathrm{kg})$ with 2-year acoustic transmitters and DSTs recording depth and temperature at 30-minute intervals. Throughout the study, concerted efforts were made to recapture, re-evaluate, and reimplant telemetered pallid sturgeon from previous years. Sturgeon collected by other agencies for use as broodstock in the Pallid Sturgeon Conservation Augmentation Program also were implanted opportunistically with transmitters before release back into the Missouri River near the site of capture. The goal of the study is to annually retain more than 80 adult pallid sturgeon with active transmitters and known reproductive histories for multiyear-term analyses of migration patterns, spawning site selection and fidelity, and reproductive frequency and success.

Telemetered pallid sturgeon were located and tracked by USGS and NGPC field crews to record habitat use and seasonal movements. Pallid sturgeon were tracked extensively, and targeted for location at monthly to weekly intervals, during pre-spawn (typically, January through March) and postspawn (typically, July through December) periods. Pallid sturgeon in reproductive condition were tracked intensively, and targeted for location at frequencies ranging from weekly to daily as temperatures increased from April through June, and fish began their upstream migrations. Location of reproductive females were attempted at least daily as water temperatures reached $14-16^{\circ} \mathrm{C}$ and spawning became imminent. Reproductive adults were tracked intensively until behavior indicated that they had spawned (DeLonay and others, 2009). Attempts were made to recapture adults as soon as possible after spawning and reproductive assessments were performed on recapture to determine that spawning was complete. Readiness to spawn or reproductive condition was assessed using ultrasound or surgical biopsy, and the status of females was further assessed using the oocyte polarization index, and when feasible, laboratory progesterone assay (Dettlaff and others, 1993). In each case, spawning success (ovulation and release of oocytes) of recaptured females was evaluated by ultrasound and confirmed by surgical biopsy (Wildhaber and others, 2007b).

Telemetry crews attempted to collect more frequent (daily to hourly) observations of fish locations and habitat use during upstream migration as temperatures approached the spawning threshold of $16^{\circ} \mathrm{C}$. Intensive telemetry tracking of pallid sturgeon in reproductive condition was prioritized among tagged individuals to better allocate resources and increase the probability of documenting spawning events. As spawning neared, selected individuals were located several times daily to monitor direction and rate of movement. Migrating females that were stationary for more than 6 hours were targeted for continuous monitoring and habitat characterization. Pallid sturgeon that were not reproductively ready were located at a targeted frequency of 1 to 3 times per month. Measurements of water quality (temperature, conductivity, dissolved oxygen, and turbidity) and habitat characteristics (depth and substrate) were recorded at each telemetry location. Spawning sites of telemetered pallid sturgeon were assessed using a combination of sampling for eggs or larvae, capturing adult pallid sturgeon in reproductive condition, and identifying and documenting spawning behavior using dual-frequency identification sonar (DIDSON) or side-scan sonar. Not all assessment methods were used at each spawning location. Methods used at each location were determined by resource availability, river conditions, and safety considerations.

\section{Progress and Results}

During the fall of 2012 and spring of 2013, the USGS and NGPC began recapturing and reimplanting telemetered pallid sturgeon in anticipation of the 2013 spawning season. Using a previously developed relational database system constructed by USGS, the Sturgeon Information Management System (SIMS), individual pallid sturgeon of both sexes were identified for recapture and reassessment based on reproductive history, movement patterns, and transmitter life expectancy (DeLonay and others, 2012). Sturgeon targeted by CSRP researchers were located and recaptured using drifted trammel nets as described in (DeLonay and others, 2007) from September through November of 2012 and from March through November of 2013. In 2013, 21 pallid sturgeon were recaptured and either reimplanted with a new acoustic tag or received a reproductive assessment. Trotline and gill net sampling for new, untagged reproductive adults began in March and continued through early-April 2013. Unseasonably cold weather and frequent heavy snowfall events hampered spring sampling efforts. Sampling crews adjusted to adverse environmental conditions by relying less on the collection of new fish and actively seeking and recapturing previously tracked fish for re-evaluation and reimplantation. Spring sampling efforts yielded only three additional, previously non-telemetered pallid sturgeon for CSRP research; two reproductive females (PLS13-001, PLS13-003) and one reproductive male (PLS13-002). 


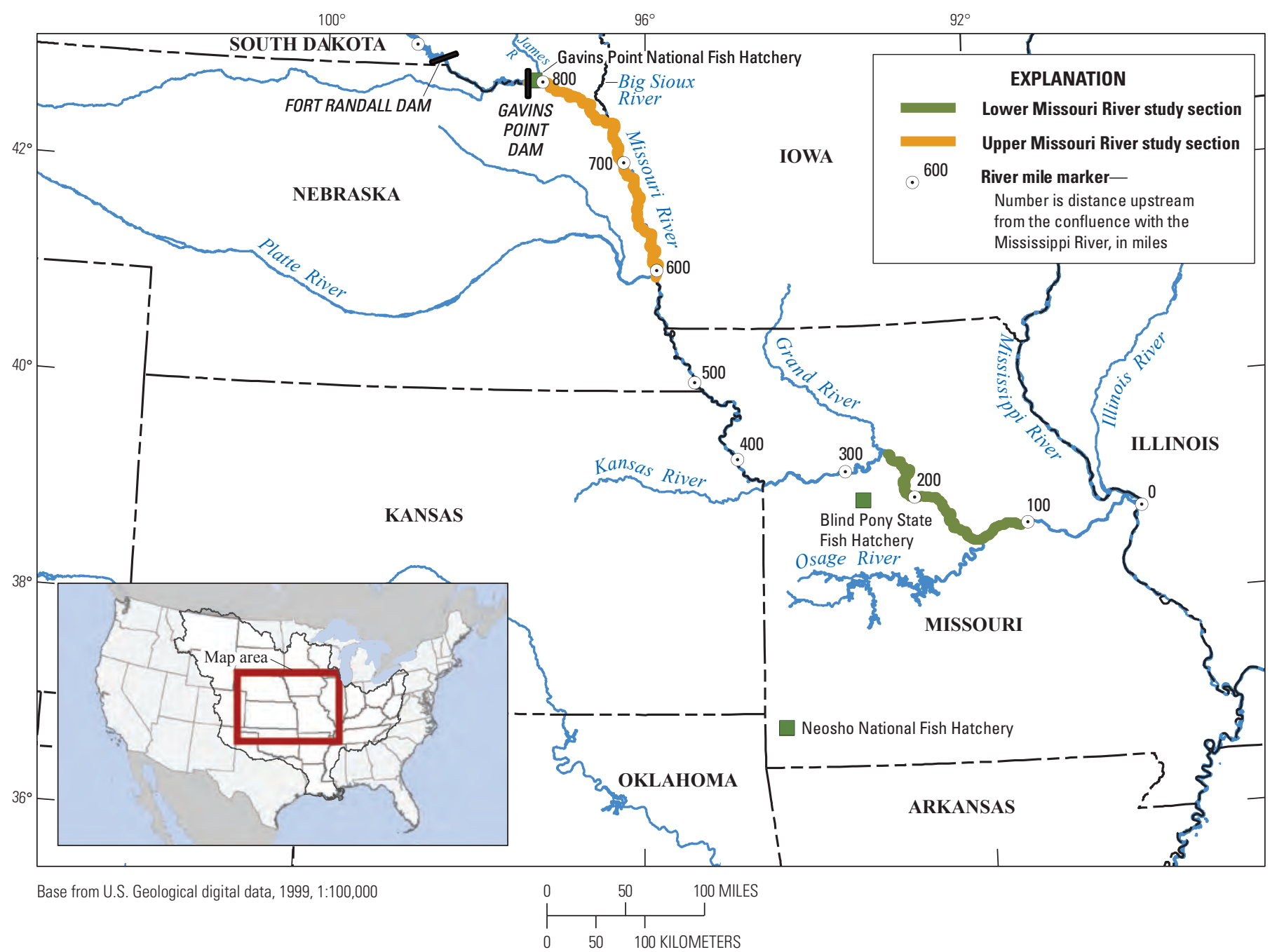

Figure 7. Study sections of the Comprehensive Sturgeon Research Project within the Lower Missouri River.

Eight female pallid sturgeon (PLS08-035, PLS11-004, PLS11-016, PLS11-017, PLS11-018, PLS11-020, PLS13-001, and PLS13-003) and one male pallid sturgeon (PLS13-002) were identified as reproductive during the fall of 2012 and spring of 2013. In previous reports tagged pallid sturgeon were identified as originating from either the upper or lower study areas within the Lower Missouri River (DeLonay and others, 2009; DeLonay and others, 2010; DeLonay and others, 2012). As more and more tagged sturgeon are recaptured and reimplanted, or derived from propagation augmentation efforts outside the study's core capture areas, it is more and more difficult to assign individual fish as originating from the lower or upper study section. Nevertheless, three of the reproductive females (PLS08-035, PLS11-004, and PLS11-018) and the one reproductive male (PLS13-002) were captured and evaluated in the Missouri River downstream from the Kansas River (river mile 369) before the spawning season. The remaining five females (PLS11-016, PLS11-017, PLS11-020, PLS13-001, and PLS13-003) were captured and evaluated in the Missouri River upstream from the Kansas River. Although the intensively tracked sturgeon in 2013 did not originate from the core study capture areas, they were functionally treated as a lower and an upper study group.

The eight gravid females were intensively tracked during the spring of 2013 to document spawning location and success. Four of the eight females were tracked to their likely spawning locations, subsequently recaptured, and determined to have spawned (PLS08-035, PLS11-018, PLS13-001, and PLS13-003) in the Missouri River. Larval sampling was executed below the spawning locations of PLS08-035 and PLS13-001. One female failed to migrate and spawn and was recaptured with oocytes in an advanced state of atresia. Two females moved up the Platte River and appear to have spawned in the tributary (PLS11-016, PLS11-020). One female moved downstream without spawning and remains to be recaptured for re-evaluation (PLS11-004).

The movements of PLS08-035 were recorded between river miles 293 to 300 from the time of her release from the pallid sturgeon conservation augmentation program during late May 2008 through January 2012. In the spring of 2012, 
PLS08-035 began a steady upstream migration, moving approximately 85 miles upstream between May and August of 2012. Evaluations of reproductive readiness on October 2, 2012, indicated that PLS08-035 would be ready to spawn during spring 2013. By December 2012, PLS08-035 descended to river mile 329 and then began a second upstream migration, reaching an apex near river mile 422.9 on May 11, 2013 (fig. 8). Comprehensive Sturgeon Research Project researchers located PLS08-035 with increasing frequency from December 2012 through April 2013, when intensive tracking was started. Spawning is believed to have been from May 10-11 between river miles 422.7 and 423.0, when water temperature ranged from 15.0 to $16.1^{\circ} \mathrm{C}$. Female PLS08-035 was recaptured on May 12, 2013, and determined to have completely spawned. The implanted DST malfunctioned and failed to collect data during the migration and spawning period. Field crews sampled for free embryos during the time that eggs were likely to hatch based on calculated developmental times at ambient river temperatures. Free-embryo sampling activities from May 15-17, 2013, immediately downstream from the probable spawning location of PLS08-035 did not result in the collection of sturgeon larvae.
Female pallid sturgeon PLS11-004 was initially captured in nonreproductive condition on March 23, 2011, near river mile 85.7 of the Lower Missouri River, implanted with a telemetry transmitter and DST, and released back into the Missouri River near her initial capture location. Evaluations of reproductive readiness on November 29, 2012, and again on March 14, 2013, indicated that PLS11-004 would be ready to spawn during spring 2013. From July through December 2012, PLS11-004 moved upstream approximately 149 miles and resumed her migration in 2013, travelling 160 miles from January through May (fig. 9). PLS11-004 reached an apex at river mile 399.7 near Leavenworth, Kans. on May 10, 2013. One week later, PLS11-004 had migrated downstream approximately 112 miles and was subsequently recaptured by field crews on May 17, 2013, near river mile 287.5. Reproductive assessments during the time of recapture determined that PLS11-004 had not spawned and that eggs were still present in her abdominal cavity. Egg samples were collected at the time of recapture and analyzed at the Columbia Environmental Research Center (CERC). Results from the egg samples determined that PLS11-004's eggs were still viable. PLS11-004 continued her downstream descent throughout the

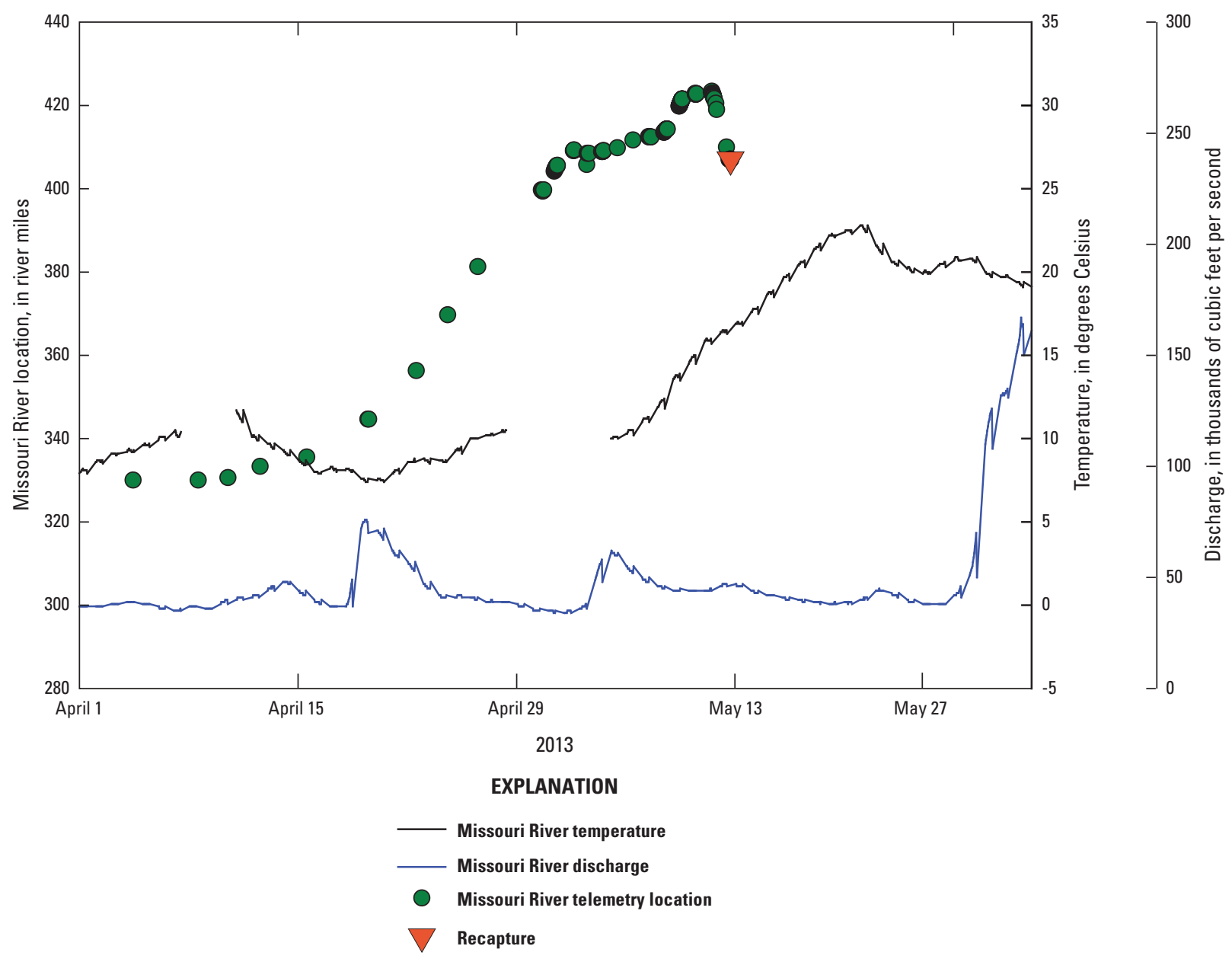

Figure 8. Telemetry locations of female pallid sturgeon PLS08-035; Missouri River temperature recorded from the nearest streamgage at Leavenworth, Kansas; Missouri River discharge recorded from the nearest streamgage at Kansas City, Missouri. 


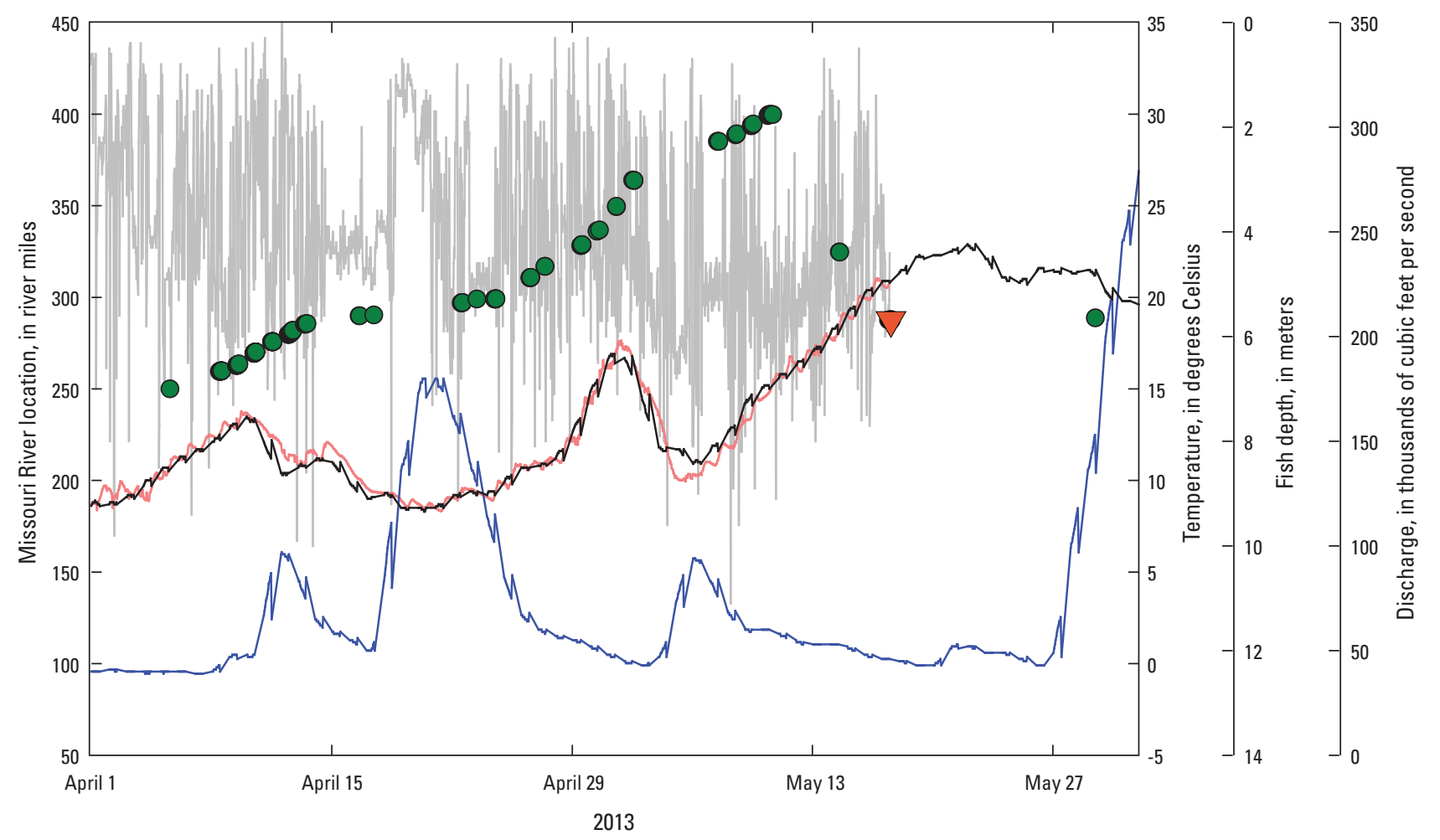

EXPLANATION

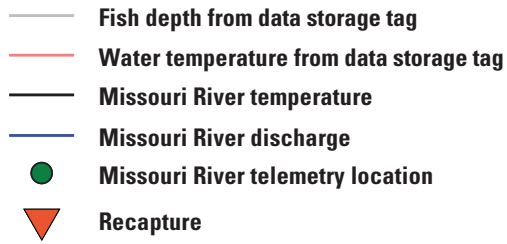

Figure 9. Telemetry locations of female pallid sturgeon PLS11-004; depth and temperature recorded from data storage tag (DST); Missouri River temperature from the nearest streamgage at Lexington, Missouri; Missouri River discharge from the nearest streamgage at Glasgow, Missouri.

spring and summer of 2013 and was last found in late October in 2013 at river mile 86.3, near her initial capture location (fig. 9). PLS11-004 has not been recaptured since May of 2013 and therefore, her 2013 spawning success has not yet been determined.

Female pallid sturgeon PLS11-016 was initially captured in reproductive condition near river mile 586 and transported to the Blind Pony State Fish Hatchery (fig. 7) on April 5, 2011. PLS11-016 was not used as broodstock for the conservation augmentation program, and was instead released to the CSRP on April 28, 2011, in reproductive condition, and implanted with a telemetry transmitter and DST. After her release into the Missouri River at river mile 591.5, PLS11-016 was not located during the 2011 spawning period. PLS11-016 was recaptured near river mile 582.5 on May 9, 2012, and surgical examination of the ovaries was consistent with a complete spawn the previous year (2011). The 2011 spawning location of PLS11-016 inferred from DST records was in the Platte River, Nebraska. On October 10, 2012, PLS11-016 was recaptured by CSRP crews near river mile 585.7 and determined to again be in reproductive condition. PLS11-016 was located on four separate occasions from November 2012 through March 2013 between river miles 578.7 and 592 (fig. 10). PLS11-016 was not located during the 2013 spring spawning period. On July 9, 2013, PLS11-016 was recaptured near river mile 584.4 and was determined to have completely spawned. PLS11016's 2013 spawning location inferred from DST records was again in the Platte River.

Female pallid sturgeon PLS11-017 was initially captured in reproductive condition near river mile 596.8 in the upper study section of the Missouri River and transported to Gavins Point National Fish Hatchery (fig. 7) on October 26, 2010. This female was not used as broodstock for the conservation augmentation program. PLS11-017 was then released to the CSRP on April 28, 2011, in reproductive condition, implanted with a telemetry transmitter and DST, and released near river mile 591.5. The fish was not located during the 2011 spawning period. PLS11-017 was recaptured near river mile 596.2 on 


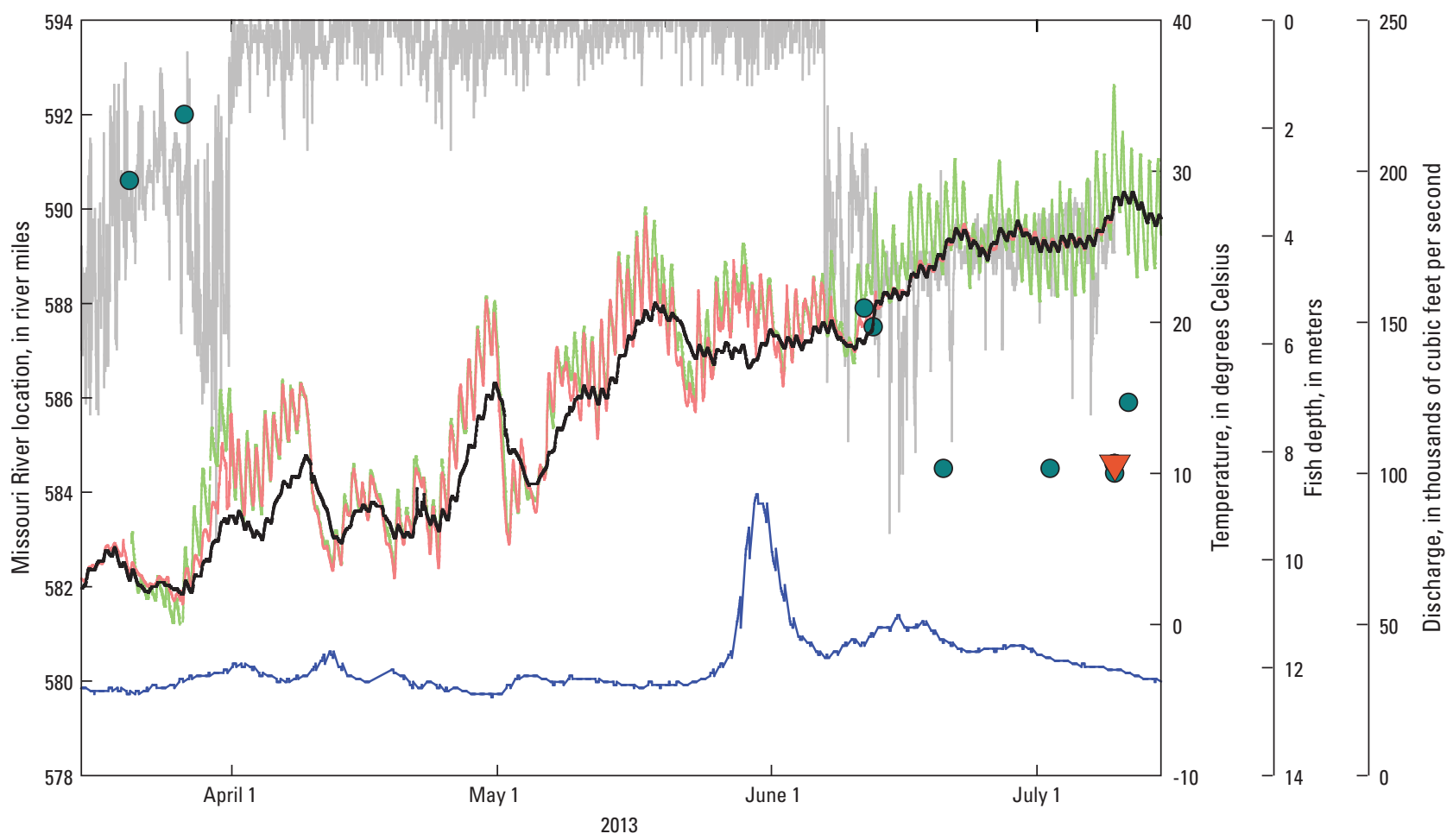

EXPLANATION

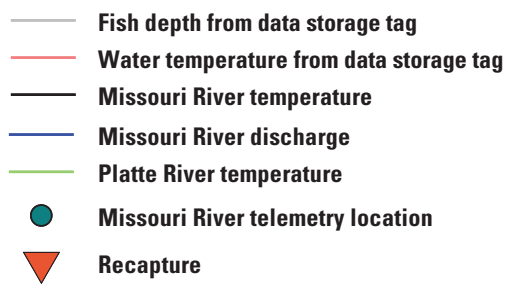

Figure 10. Telemetry locations of female pallid sturgeon PLS11-016; depth and temperature recorded from data storage tag (DST); Missouri River temperature from nearest streamgage at Omaha, Nebraska; Missouri River discharge from the nearest streamgage at Nebraska City, Nebraska; Platte River temperature from the nearest streamgage at Louisville, Nebraska.

March 22, 2012 and determined to have spawned completely. PLS11-017's 2011 spawning location inferred from DST tag temperature records was in the Missouri River. From March through October of 2012, PLS11-017 was located on 36 different occasions between river miles 595.5 and 601 (fig. 11). This female was targeted for recapture and reimplantation on October 11, 2012. Field assessments of reproductive condition at the time indicated that this female would likely spawn during spring 2013. This female was intensively tracked during the 2013 spawning season. Reproductive assessments on May 24, 2013, and again on June 4, 2013, confirmed that PLS11-017 was still in reproductive condition. On July 9, 2013, PLS11017 was recaptured near river mile 594.4 and her oocytes were determined to be in a state of advanced atresia.

Female pallid sturgeon PLS11-018 was initially captured in the Lower Missouri River and transported to the Neosho National Fish Hatchery (fig. 7) on April 23, 2010. PLS11018 was unsuccessfully used for artificial propagation in the spring of 2011. The female was then released to the CSRP on May 4, 2011, in reproductive condition, implanted with a telemetry transmitter and DST, and released near river mile 185.1. PLS11-018 was recaptured near river mile 188.1 on June 10, 2011, and her oocytes were determined to be in a state of advanced atresia. This female made a steady upstream migration over the course of a 1-year period (September 2011 to October 2012), travelling approximately 409 miles and reaching an apex at river mile 609.4 on October 10, 2012. On October 11, 2012, PLS11-018 was recaptured near river mile 605.2. Oocytes were large and grey indicating that she would likely spawn during spring 2013. PLS11-018 was intensively tracked during the spring 2013 spawning season, but was not located between March 21, 2013, and May 15, 2013. PLS11018 was located during an upstream migration on May 16, 2013, by crews intensively tracking another fish. PLS11-018 reached her spawning apex between May 17 and May 20, 2013, near river mile 592.2. On May 20, 2013, PLS11-018 


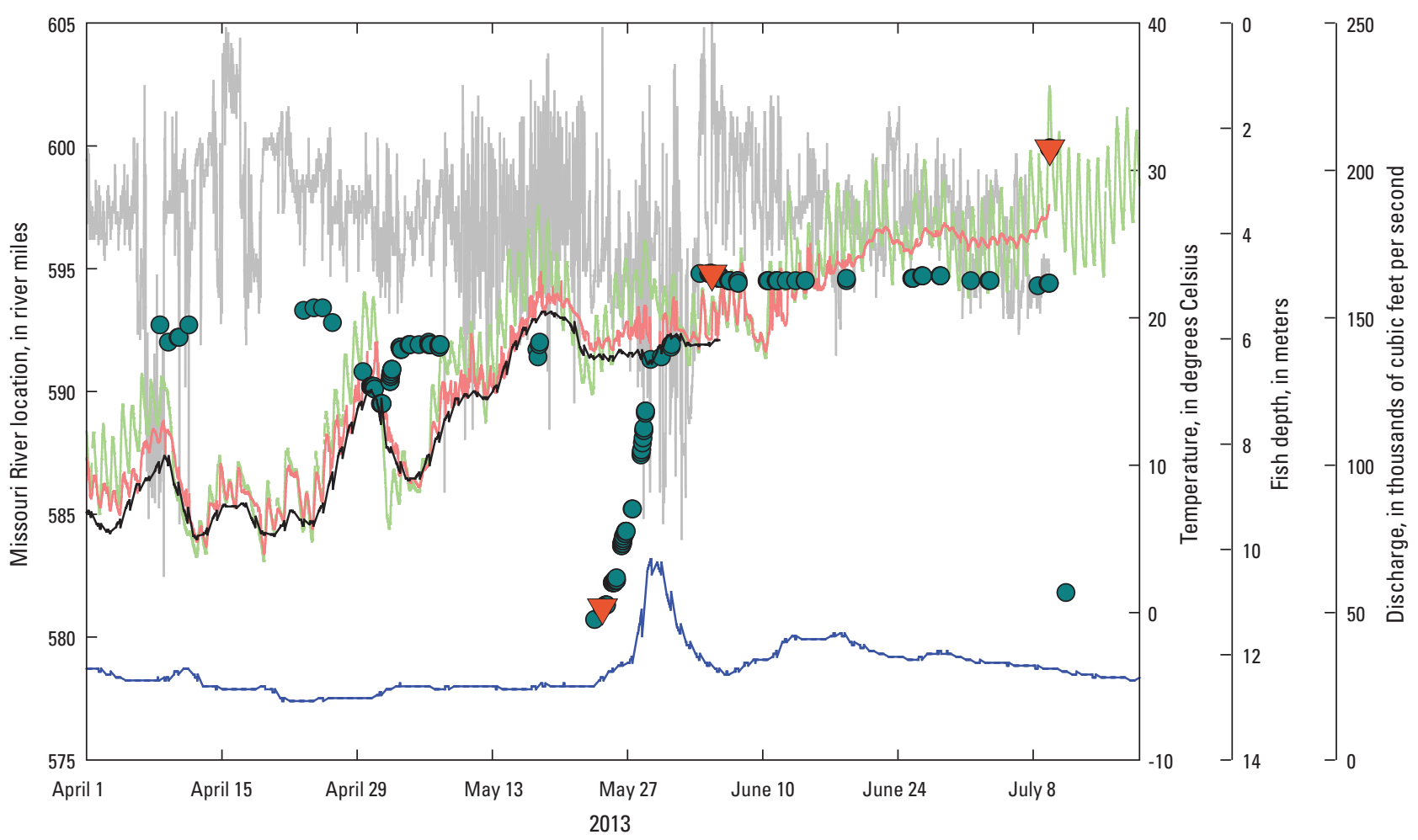

EXPLANATION

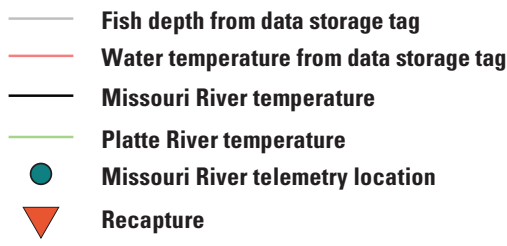

Figure 11. Telemetry locations of female pallid sturgeon PLS11-017; depth and temperature recorded from data storage tag (DST); Missouri River discharge and temperature from the nearest streamgage at Omaha, Nebraska; Platte River temperature from the nearest streamgage at Louisville, Nebraska.

was recaptured near river mile 591.4 and determined to have completely spawned with a few viable eggs remaining in the body cavity on recapture. Temperature data downloaded from the implanted DST closely matched the temperature profile of the Missouri River during the 2013 spawning period (fig. 12). Based on the comparison of temperature profiles, PLS11-018 is believed to have spawned in the Missouri River. A spawning date of May 16-20, 2013, and spawning location between river miles 591.9-592.2 is assigned based upon migration data and the condition of the oocytes on recapture. Spawning behavior was not observed. Because the spawning location was determined by inference after recovery of the female and analysis of the DST data, the spawning location was not mapped in 2013.

Female pallid sturgeon PLS11-020 was initially captured near river mile 564.9 and transported to the Neosho National Fish Hatchery on April 9, 2010. This female was retained in the conservation augmentation program for more than 1 year before being released to the CSRP on May 4, 2011, in reproductive condition. She was implanted with a telemetry transmitter and DST and released near river mile 591.4. After her release into the Missouri River, PLS11-020 was not located during the 2011 spawning period. PLS11-020 was recaptured near river mile 580.7 on March 22, 2012, and determined to have spawned completely. PLS11-020's 2011 spawning location inferred from DST records was in the Platte River. On March 20, 2013 PLS11-020 was recaptured by CSRP crews near river mile 590.6 and determined to be in reproductive condition. PLS11-020 was located on four separate occasions from March 2013 through April 2013 between river miles 589.8 and 594.8. On June 12, 2013, PLS11-020 was recaptured near river mile 588.4 and was determined to have completely spawned. The 2013 spawning location of PLS11020 inferred from data storage tag records was again in the Platte River (fig. 13). 


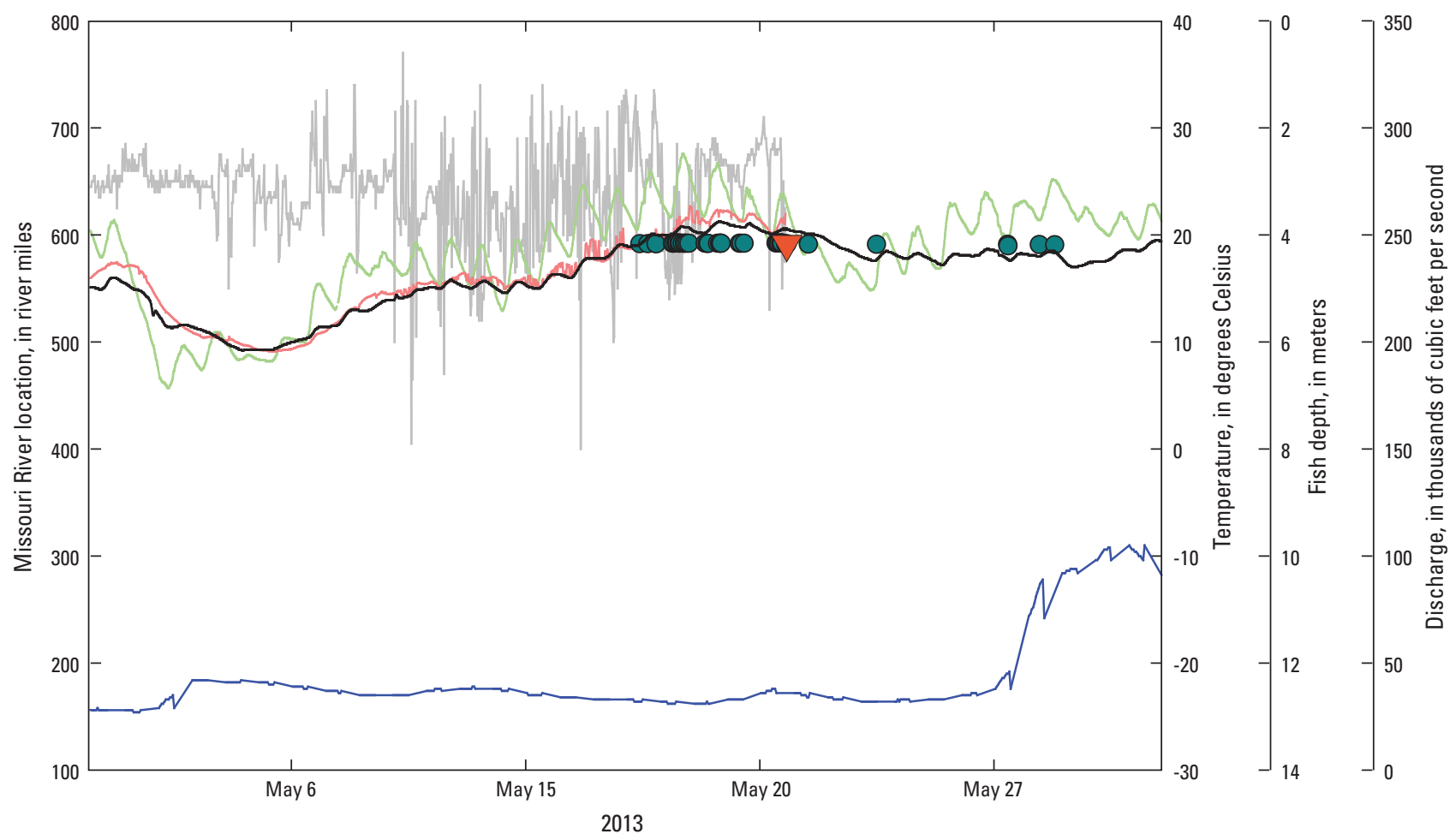

EXPLANATION

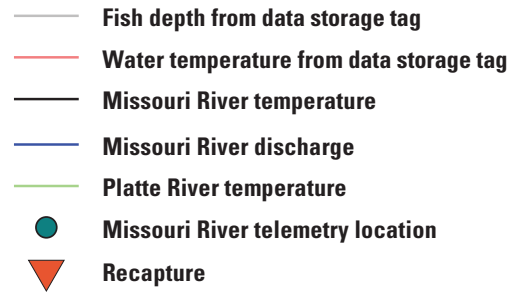

Figure 12. Telemetry locations of female pallid sturgeon PLS11-018; depth and temperature recorded from data storage tag (DST); Missouri River temperature from the nearest streamgage at Omaha, Nebraska; Missouri River discharge from the nearest streamgage at Rulo, Nebraska; Platte River temperature from the nearest streamgage at Louisville, Nebraska.

Female pallid sturgeon PLS13-001 was initially captured in reproductive condition near river mile 341.2 on April 2, 2013. PLS13-001 moved consistently upstream until May 10 , when she began moving downstream, suggesting that she may have spawned (fig. 14). PLS13-001 was recaptured near river mile 396.4 on May 13, 2013 and determined to have spawned completely. Spawning is believed to have been from May 10 to May 11 between river miles 389.6 and 399.1. The suspected spawning location was sampled for larvae from May 15 to May 17, 2013. One early stage Scaphirhynchus spp. free embryo was collected immediately downstream from the probable spawning site of PLS13-001. This specimen was remitted to Dr. Edward Heist at Southern Illinois University Carbondale for genetic testing and determined to be a shovelnose sturgeon (Scaphirhynchus platorynchus).

Female pallid sturgeon PLS13-003 was initially captured in reproductive condition near river mile 587 and transported to the Blind Pony State Fish Hatchery on April 5, 2013. The female did not meet genetic criteria for use in the conservation broodstock program. The female was then released to the CSRP on May 2, 2013, in reproductive condition, implanted with a telemetry transmitter and DST and released near river mile 591.7. PLS13-003 traveled upstream, reaching an apex on May 10, 2013, near river mile 613.4, then began moving downstream on the same day. PLS13-003 was recaptured on May 20, 2013, and determined to have spawned completely. Temperature data downloaded from the implanted DST closely matched the temperature profile of the Missouri River during the 2013 spawning period (fig. 15). Based on observed behavior during intensive tracking PLS13-003 is believed to have spawned in the Missouri River on May 12-13, 2013, between river miles 603.5-603.8 after exhibiting a short, but complex migration pattern. 


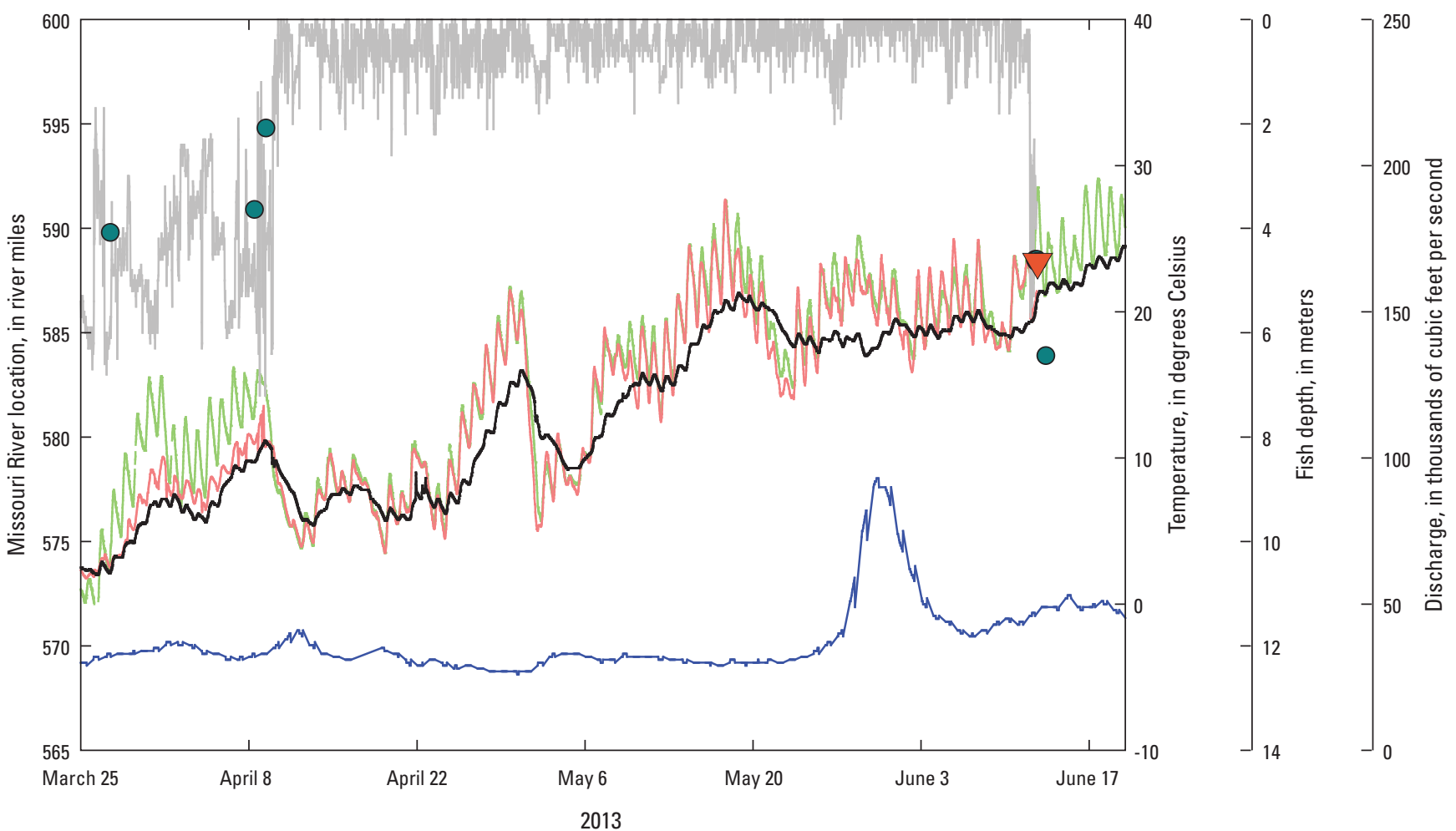

EXPLANATION

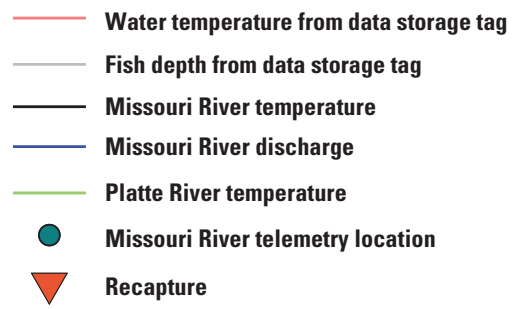

Figure 13. Telemetry locations of female pallid sturgeon PLS11-020; depth and temperature recorded from data storage tag (DST); Missouri River temperature from the nearest streamgage at Omaha, Nebraska; Missouri River discharge from the nearest streamgage at Nebraska City, Nebraska; Platte River temperature from the nearest streamgage at Louisville, Nebraska.

Male pallid sturgeon PLS13-002 was initially captured in reproductive condition near river mile 177.2 on April 6, 2013. Approximately 1 month later, PLS13-002 was located more than 200 miles upstream of his point of capture near river mile 398.2 (fig. 16). PLS13-002 continued his upstream migration, traveling another 190 miles upstream where he reached his migration apex just above Plattsmouth, Nebraska, at river mile 593. After the 2013 spawning season was complete, PLS13002 began his downstream migration. Tracking crews located PLS13-002 almost 490 miles downstream near Hermann, Missouri, at river mile 105.6 by July 17, 2013.

In addition to intensive tracking of reproductive females, efforts were made during 2013 to identify reproductive states of telemetered male pallid sturgeon and to use males to potentially identify spawning aggregations. On May 22, 2013, male pallid sturgeon PLS08-048 was targeted for reproductive assessment near river mile 594, just downstream from the mouth of the Platte River. During the recapture effort of PLS08-048, four non-telemetered male pallid sturgeon, identified by passive integrated transponder codes (PIT), (PIT 47154C4C7B, PIT 431B384572, PIT 4349697F6C, and PIT 48643A7120) were incidentally captured by deployed trammel nets. PLS08-048 was not recaptured in the effort. Three of the male pallid sturgeon (PIT 47154C4C7B, PIT 4349697F6C, and PIT 48643A7120) were determined to be in reproductive condition and expressing milt. Reproductive status was confirmed by ultrasound. The following day, on May 23rd, a fourth reproductive male, PLS10-032, was captured just upstream from the male aggregation recorded the previous day. Loose aggregations of males have been previously documented by the CSRP in the Yellowstone River, North Dakota a few miles upstream from the confluence with the Missouri River (DeLonay and others, 2016). 


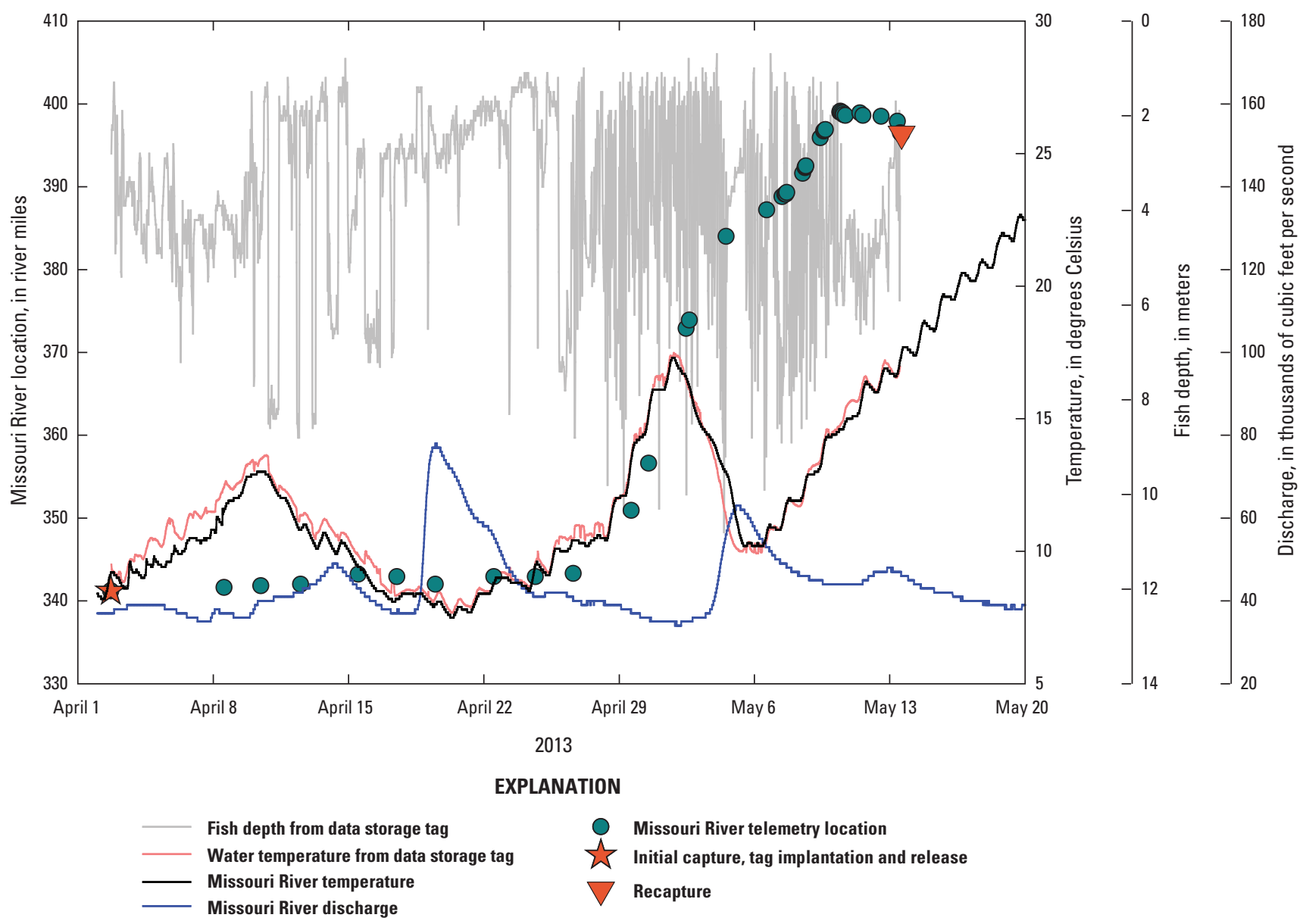

Figure 14. Telemetry locations of female pallid sturgeon PLS13-001, depth and temperature recorded from data storage tag (DST); Missouri River temperature and discharge from the nearest streamgage at Kansas City, Missouri.

\section{Discussion}

Intensive and extensive tracking of telemetered pallid sturgeon since 2007 has resulted in the documentation of 23 spawning events by 22 individual females in the Lower Missouri River (fig. 17) and 6 spawning events by 4 different females in the Platte River (table 1). With consistent multiyear observations, repeated spawning migrations and spawning events are being observed. Based on limited data, female pallid sturgeon tagged by the CSRP in the Lower Missouri River may spawn as frequently as every 2 to 3 years. Males may spawn as frequently as every 1 to 2 years. Data are currently (2015) insufficient to determine typical or mean spawning frequencies in the Lower Missouri River. Spawning in the Lower Missouri River typically happens from the end of April to mid-May, but annual temperature variation may alter the spawning period. Spawning in 2012 was several weeks early because of an unusually warm spring. Spawning in 2013 was slightly delayed compared to previous years, perhaps because of a cooler than usual spring.

The precision with which it is possible to estimate when and where spawning has taken place varies. Based on observations of intensively tracked pallid sturgeon that were recaptured and known to have spawned, we have defined spawning as occurring over a few hundred meters $(\mathrm{m})$ of an outside bend of the river in a 24-36 hour period (DeLonay and others, 2009) after a characteristic upstream migration. Estimates of the spawning location and timing of other telemetered females may be more broadly defined, especially if the migration pattern of intensively tracked females was complex and disrupted without clear observation of spawning behavior, or if the females had only a few observations between the initial reproductive evaluation and the post-spawn recapture (DeLonay and others, 2009; DeLonay and others, 2012). The precise locations of egg deposition at spawning sites in the Lower Missouri are currently (2015) unknown. Additional methods and technology are required to more precisely locate and characterize areas selected by pallid sturgeon for egg deposition to appropriately assess the suitability of available habitat and evaluate survival of developing embryos. Despite locating spawning locations at a fine resolution (10's to 100's of meters) in the Lower Missouri River, we have yet to be able to detect pallid sturgeon free embryos.

Individual pallid sturgeon of both sexes have been documented returning to the same section of river or to specific tributaries to spawn with surprising fidelity. Multiyear tracking 


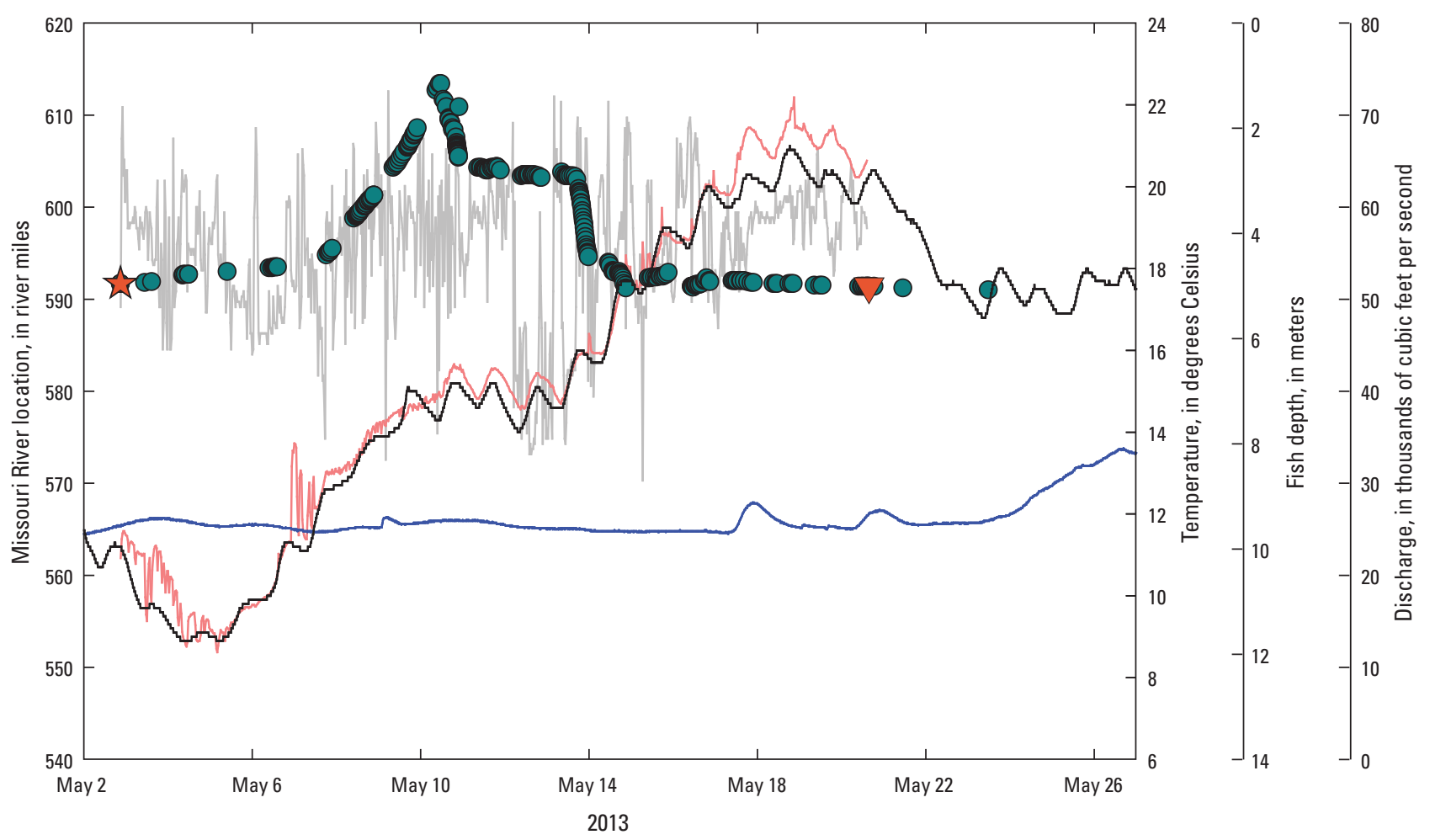

EXPLANATION
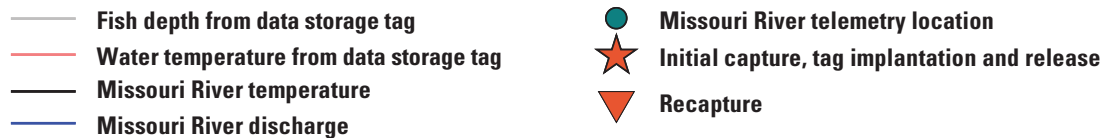

Figure 15. Telemetry locations of female pallid sturgeon PLS13-003; depth and temperature recorded from data storage tag (DST); Missouri River temperature and discharge from the nearest streamgage at Omaha, Nebraska.

of individual pallid sturgeon will be required to assess the level of spawning site fidelity and the role this geographic specificity may play in preserving the population genetic structure. In three consecutive years, 2011-2013, female pallid sturgeon have migrated upstream into the Platte River in reproductive condition and likely spawned. Aggregations of male pallid sturgeon in reproductive condition near the mouth of the Platte River also were observed for the first time in 2013. Consistent multiyear observations and greater numbers of hatchery progeny reaching reproductive maturity in the Lower Missouri River will contribute greatly to our ability to identify important habitats and reaches of river, and to gauge the relative importance of tributaries to recovery.

\section{Habitat Use and Availability during Migration, Spawning, and Drift}

In 2013, we continued to quantify the use and availability of physical habitat selected by pallid sturgeon for reproductive migration, spawning, and free-embryo drift on the Lower Missouri River (Braaten and others, 2008; Reuter and others, 2008; DeLonay and others, 2009; Elliott and others,
2009; Jacobson and others, 2009; Reuter and others, 2009; Braaten and others, 2010; Bonnot and others, 2011; Braaten and others, 2012a; McElroy and others, 2012). This multiyear effort has involved characterizing the migration and spawning habitats of gravid females, contrasting selected habitats with nearby habitats, and evaluating potential migratory and spawning responses to spring flow pulses, including intentional flow pulses from Gavins Point Dam. Previous years' data (Reuter and others, 2008; DeLonay and others, 2009; Elliott and others, 2009; Jacobson and others, 2009; Reuter and others, 2009) document habitat use at spawning sites of shovelnose and pallid sturgeon as well as variability in the availability of habitats in the Lower Missouri River. These data demonstrate that spawning on the Lower Missouri River is typically on or near outside bend revetment rocks or bedrock in deep high-velocity zones adjacent to the thalweg.

During 2013, we expanded the investigations of hatch, drift, and settling life stages. Understanding these early life stages necessarily includes tracking reproductive adults to their spawning locations to characterize conditions for egg deposition, fertilization, and hatch, and to identify origins of drifting free embryos. Key questions include duration of drift, drift velocity (relative to current velocity), distribution 


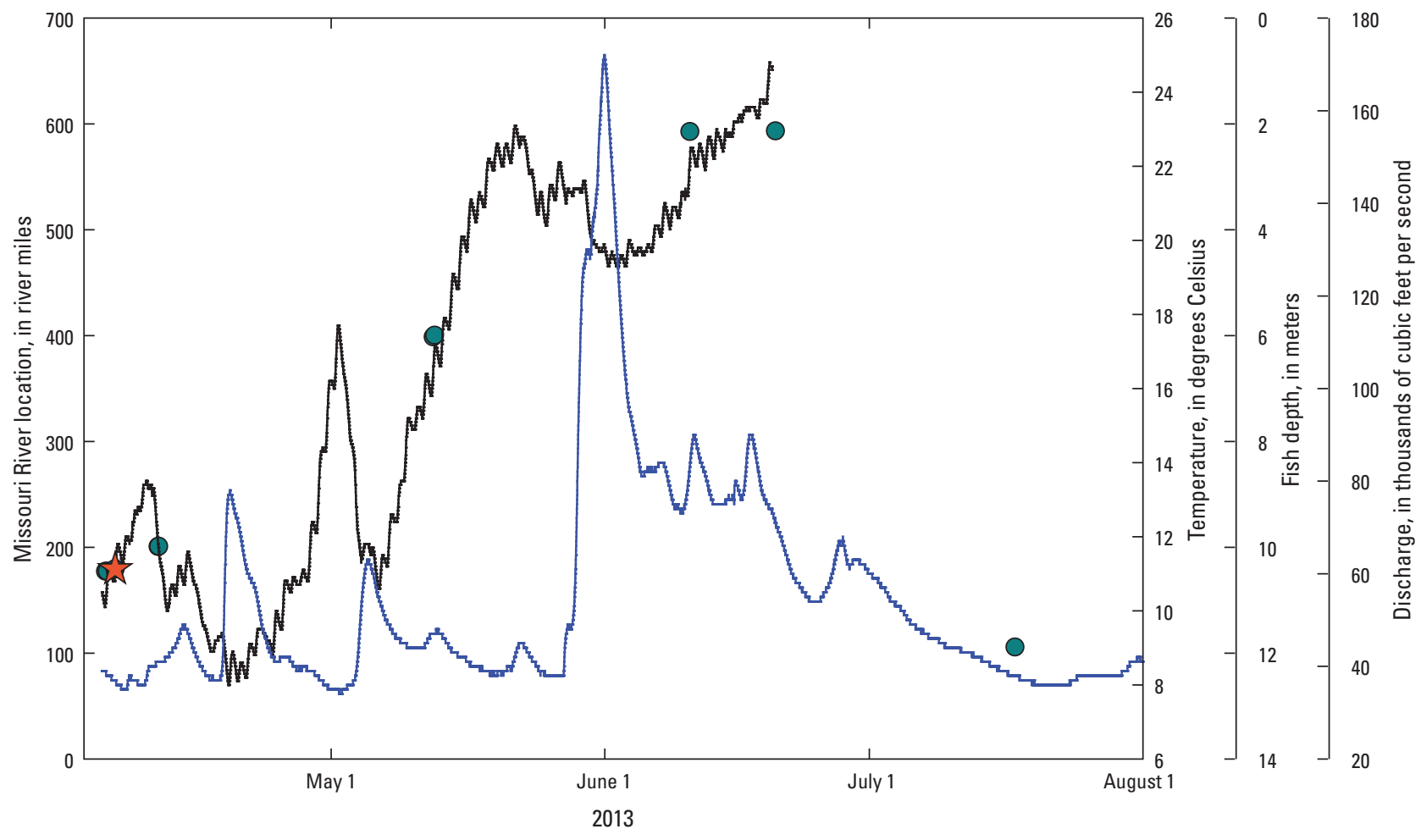

EXPLANATION

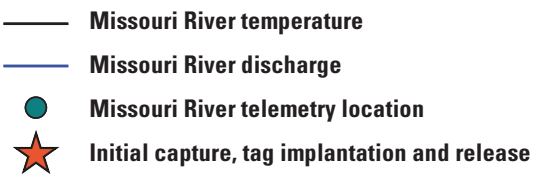

Figure 16. Telemetry locations of male pallid sturgeon PLS13-002; Missouri River temperature from the nearest streamgage at Lexington, Missouri; Missouri River discharge from the nearest streamgage at Kansas City, Missouri.

of free embryos within the channel, and conditions that affect the probability of free embryos moving from the thalweg into marginal retention areas (settling). Free embryos and larval fish at different developmental stages interact with the geomorphology and hydraulics of the channel, which may strongly affect where along the river they are retained and initiate feeding, or whether or not they continue to be transported past the point of starvation or into habitats that are unsuitable.

Once hatched, the transport and fate of free embryos are largely unknown. Laboratory studies in low-velocity environments have established that movement of free embryos includes substantial vertical components, especially as they need to surface to fill their air bladders before settling to initiate feeding (DeLonay and others, 2012). This process could be especially challenging within the high velocities that characterize spawning locations. Free embryos may drift for 9-17 days, depending on temperature-mediated development rate, before using up their yolk sac and "settling" into feeding environments (Kynard and others, 2002; Braaten and others, 2008). During this time they develop some ability to move on their own. Field experiments on the Yellowstone
River indicate that free embryos tend to concentrate in the thalweg (Braaten and others, 2010) and drift at velocities 0.09-0.2 meters per second $(\mathrm{m} / \mathrm{s})$ slower than mean water velocity (Braaten and others, 2008). Older free embryos and larvae tend to drift slower as they settle, or orient to benthic habitats. Mean water velocities in the Lower Missouri River suggest free embryos may drift hundreds of miles per day (DeLonay and others, 2009), but it is unknown how complex hydraulics along the river may interact with progressive development to determine actual drift distances, where larvae may ultimately be retained, and whether retention sites provide necessary food resources and lack of predation. Poor recruitment to young of the year indicates that drift and retention processes may be critical in determining growth and survival of pallid sturgeon.

The objectives of studies within the Task 1 habitat subtask were to characterize habitat at spawning and hatching sites, characterize habitat at free-embryo drift measurement sites, improve estimates of drift distance and retention probability in the Lower Missouri River, and to evaluate spatial patterns in dispersion characteristics among river segments. 


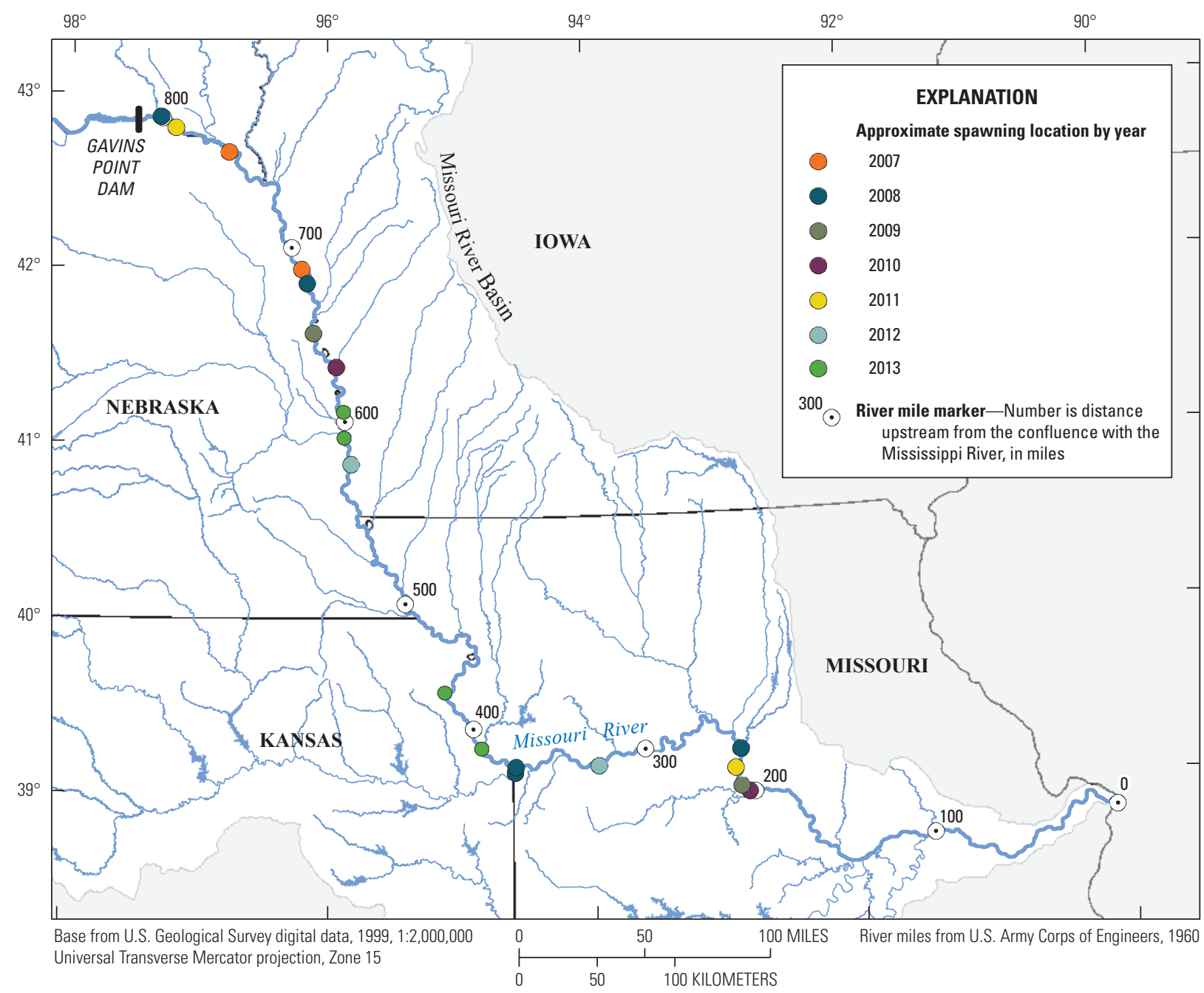

Figure 17. Locations of spawning sites used by telemetered pallid sturgeon in the Lower Missouri River, $2007-13$.

\section{Methods}

\section{Habitat and Habitat Dynamics at Spawning and Free- Embryo Drift Sites}

As in previous years, spawning sites were identified through tracking of reproductive females. We documented spawning habitat using protocols for high-resolution multibeam bathymetric mapping and acoustic Doppler current profiler (ADCP) velocity mapping, coupled with real-time kinematic (RTK) GPS equipment to provide precise positioning. Mapping at spawning locations extended over adjacent areas to allow characterization of all habitats available during spawning, as well as the patch directly used by the sturgeon. Hydroacoustic data were processed and used to create maps of depth, velocity, and substrate, and to extract quantitative data for statistical analyses (Elliott and others, 2004; Jacobson and others, 2004b; Gaeuman and Jacobson, 2005, 2006). Our mapping protocols supplement previous years' data providing habitat information around sturgeon locations at a spatial resolution appropriate to the fish. This mapping effort serves to quantify spawning habitats sought out by sturgeon and characterizes the environments where free-embryo drift begins.

In addition to the habitat mapping at spawning sites, we mapped velocities at free-embryo sampling sites. Sampling methods for free embryos are described in the following section. Mapping of free-embryo sampling sites was less extensive than mapping of spawning sites, because we limited velocity mapping to transects where samples were actively being collected. The velocity data were collected using differential GPS for positioning.

\section{Analysis of Drift Potential}

To evaluate retention probability of free embryo and larval fishes in the Lower Missouri River, we calculated longitudinal dispersion coefficients for morphologically distinct segments of the river. Dispersion coefficients were calculated directly from an existing library of ADCP data 


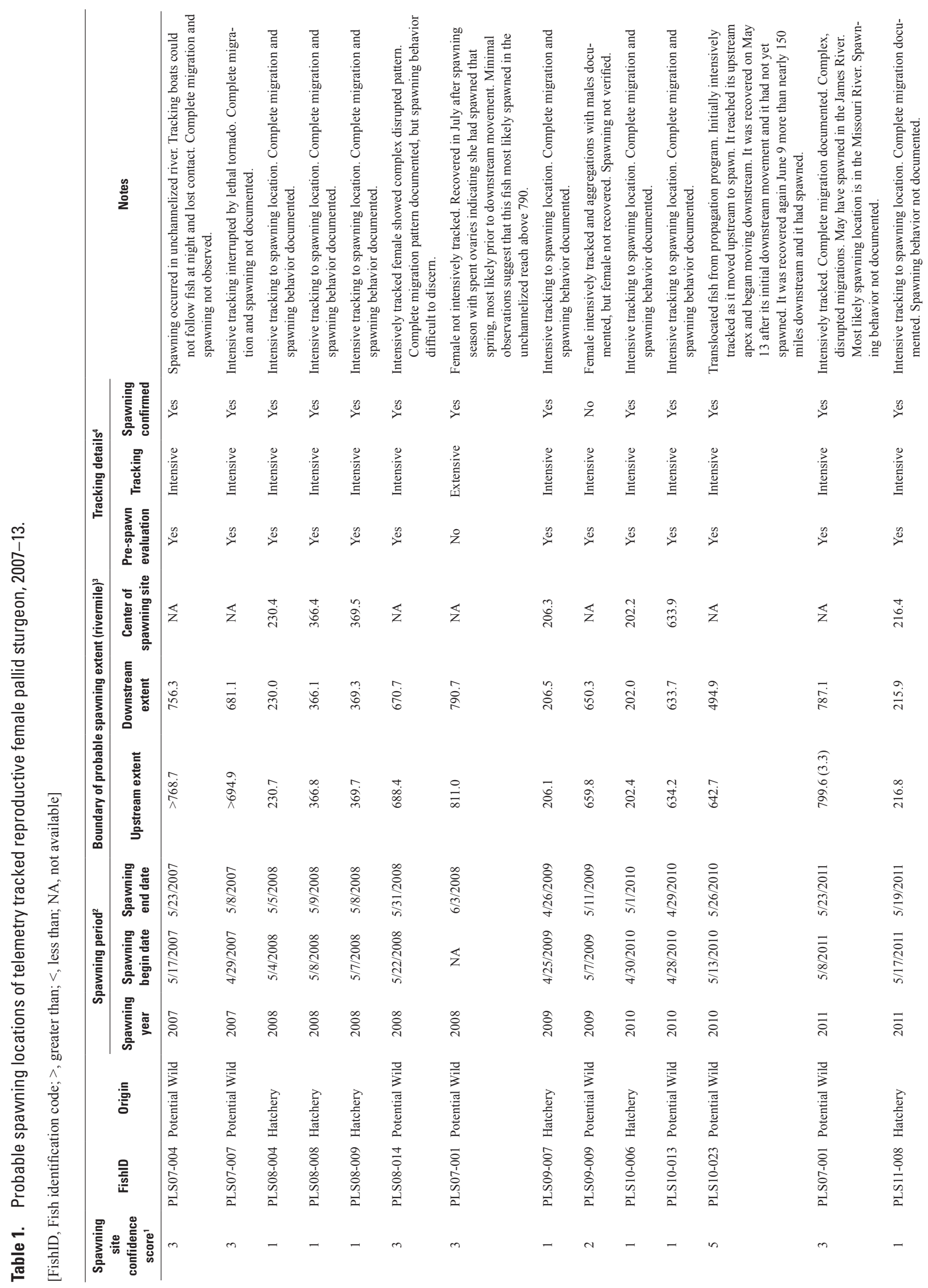




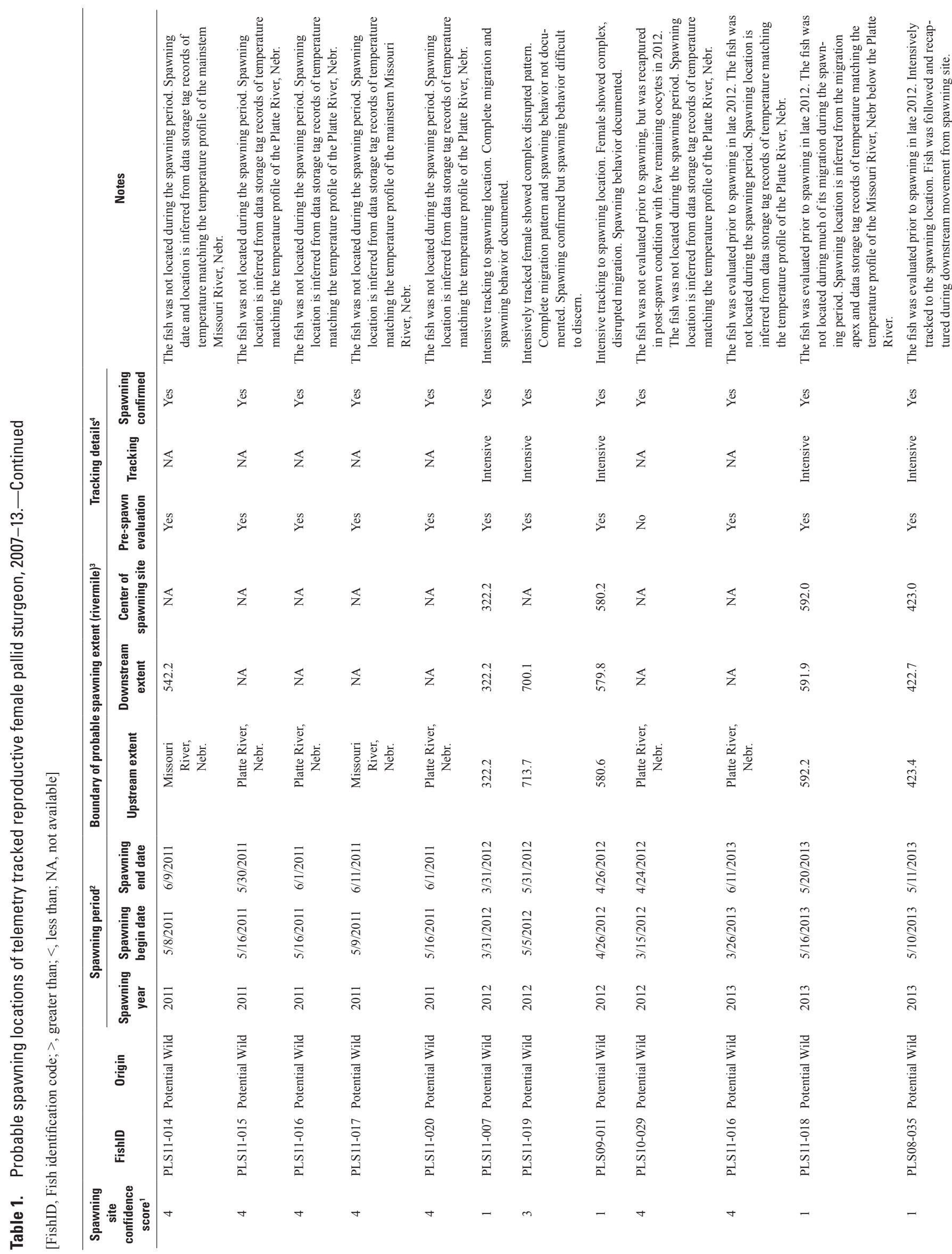




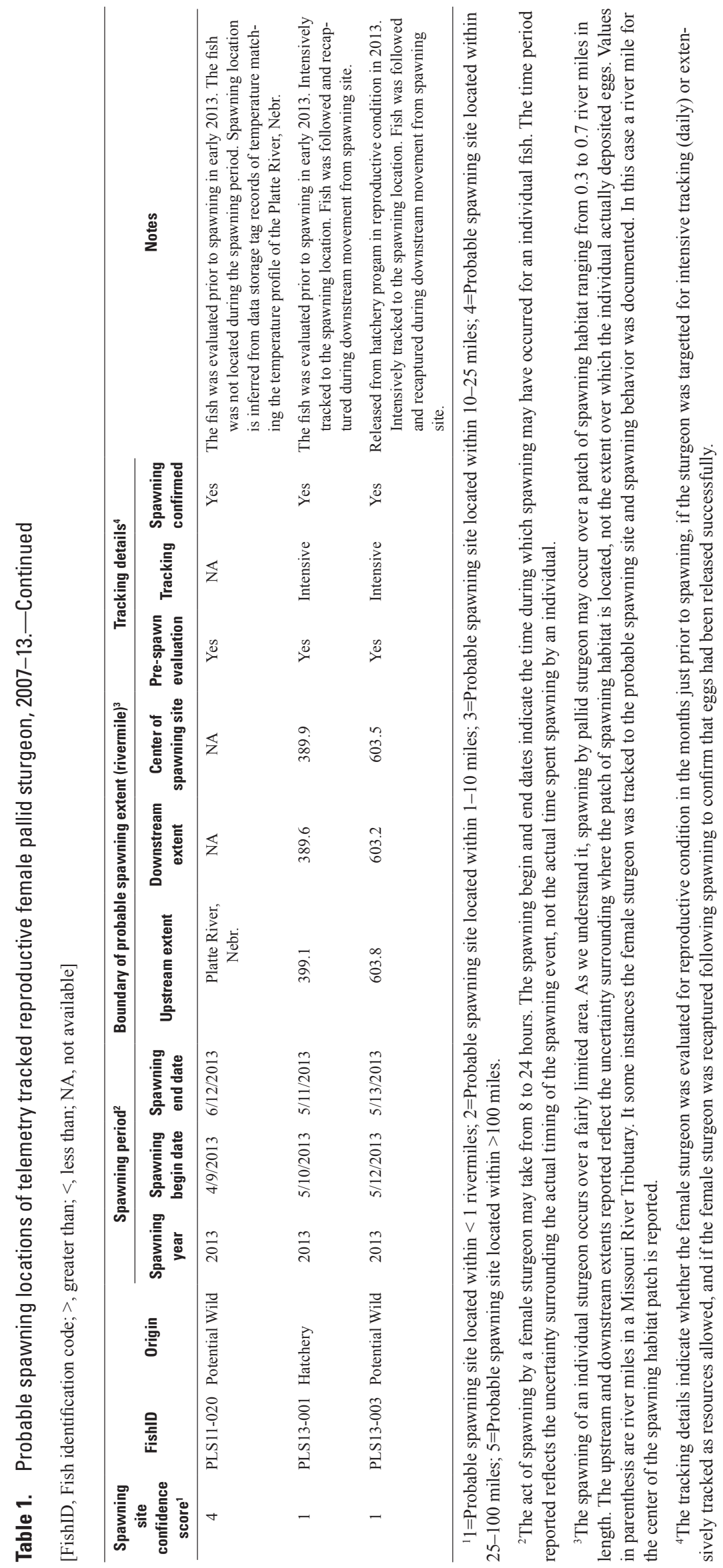


(Carr and Rehmann, 2007; Shen and others, 2010; Kim, 2012). We performed statistical analyses of dispersion coefficients derived from ADCP data to evaluate retention and dispersion characteristics among river segments. Dispersion coefficients also were analyzed to explore systematic variations of dispersion coefficients with discharge. Additionally, to improve on estimates of cumulative drift distance, we used reach average values of longitudinal dispersion coefficients $\left(D_{L}\right)$ to model drift at documented spawning sites. These calculations provide first-order estimates of cumulative drift distances along the Lower Missouri River. The primary objective of this modeling effort was not to predict the precise location of drifting embryos, but to use the model scenarios to explore the controls on cumulative drift distance. These methods are described in detail in (DeLonay and others, 2016).

\section{Progress and Results}

\section{Habitat and Habitat Dynamics at Spawning and Hatching Sites}

In 2013, we recorded river bathymetry and velocities at three spawning sites in the main-stem Lower Missouri River (table 2). The number of spawning sites mapped was limited by the number of sites documented by telemetry crews. Three spawning sites were mapped using the high-resolution multibeam habitat protocol, which includes a $1-2 \mathrm{~km}$ reach-long swath map and ADCP mapping at 20-m transects perpendicular to the flow. At the spawning site of PLS08-035 located at river mile 423, near Atchison, Kansas, spawning was documented on May 10-11, 2013, and habitat mapping was done on May 13-14, 2011 (figs. 18 and 19). At the spawning site of PLS13-001 located at river mile 399, near Leavenworth, Kansas, spawning was documented on May 10-11, 2013, and habitat mapping was done on May 15-16, 2011 (figs. 20 and 21). At the spawning site of PLS13-003 located at river mile 603, near Bellevue, Nebraska, spawning was documented on May 12-13, 2013, and habitat mapping was done on May 22, 2013 (figs. 22 and 23). At all three sites, spawning was along the outside of a meander bend, in an area of relatively high velocities and where the bank was armored with coarse revetment. In addition to the mapping of spawning sites, we mapped one migration pathway in which a reproductive female traveled through a chute located at river mile 281 while swimming upstream. On April 12, 2013, a reproductive female (PLS11-004) traveled up the chute over the course of approximately 3 hours (fig. 24). Habitat mapping was done on May 8,2013 . Discharge, as measured at Waverly, Missouri, was 52,600 cubic feet per second $\left(\mathrm{ft}^{3} / \mathrm{s}\right)$ on the day of the migration and $50,500 \mathrm{ft}^{3} / \mathrm{s}$ on the day of mapping.

Table 2. Summary data for habitat assessment efforts in 2013.

[Habitat surveyed denotes habitat type; fish ID, fish identification code; river mile location gives the upstream and downstream extent of each survey; discharge is reported as the mean discharge through the course of the survey at the streamgage given in the nearest streamgage column; $\mathrm{ft}^{3} / \mathrm{s}$, cubic foot per second; survey type denotes the mothods used for each survey; Mo., Missouri; ADCP, acoustic Doppler current profiler; Nebr., Nebraska]

\begin{tabular}{|c|c|c|c|c|c|c|}
\hline $\begin{array}{l}\text { Habitat } \\
\text { surveyed }\end{array}$ & Fish ID & $\begin{array}{c}\text { Date } \\
\text { (month/ } \\
\text { day/year) }\end{array}$ & $\begin{array}{l}\text { River mile } \\
\text { location }\end{array}$ & $\begin{array}{c}\text { Nearest } \\
\text { streamgage }\end{array}$ & $\begin{array}{c}\text { Discharge, } \\
\text { in cubic feet } \\
\text { per second } \\
\left(\mathrm{ft}^{3} / \mathrm{s}\right)\end{array}$ & Survey type \\
\hline Migration & PLS08-035 & $5 / 8 / 2013$ & $280.5-282.0$ & Waverly, Mo. & 50,500 & $\mathrm{ADCP}$ \\
\hline Spawning & PLS08-035 & $5 / 13 / 2013$ & $422.3-423.4$ & St. Joseph, Mo. & 39,200 & $\mathrm{ADCP}$ \\
\hline Spawning & PLS08-035 & $5 / 14 / 2013$ & $422.6-423.4$ & St. Joseph, Mo. & 37,400 & ADCP and multibeam \\
\hline Spawning & PLS11-004/PLS13-001 & $5 / 15 / 2013$ & $398.4-399.8$ & St. Joseph, Mo. & 36,400 & $\mathrm{ADCP}$ \\
\hline Spawning & PLS11-004/PLS13-001 & $5 / 16 / 2013$ & $398.4-399.8$ & St. Joseph, Mo. & 35,700 & Multibeam \\
\hline Spawning & PLS13-003 & $5 / 22 / 2013$ & $603.1-603.8$ & Omaha, Nebr. & 25,400 & ADCP and multibeam \\
\hline
\end{tabular}




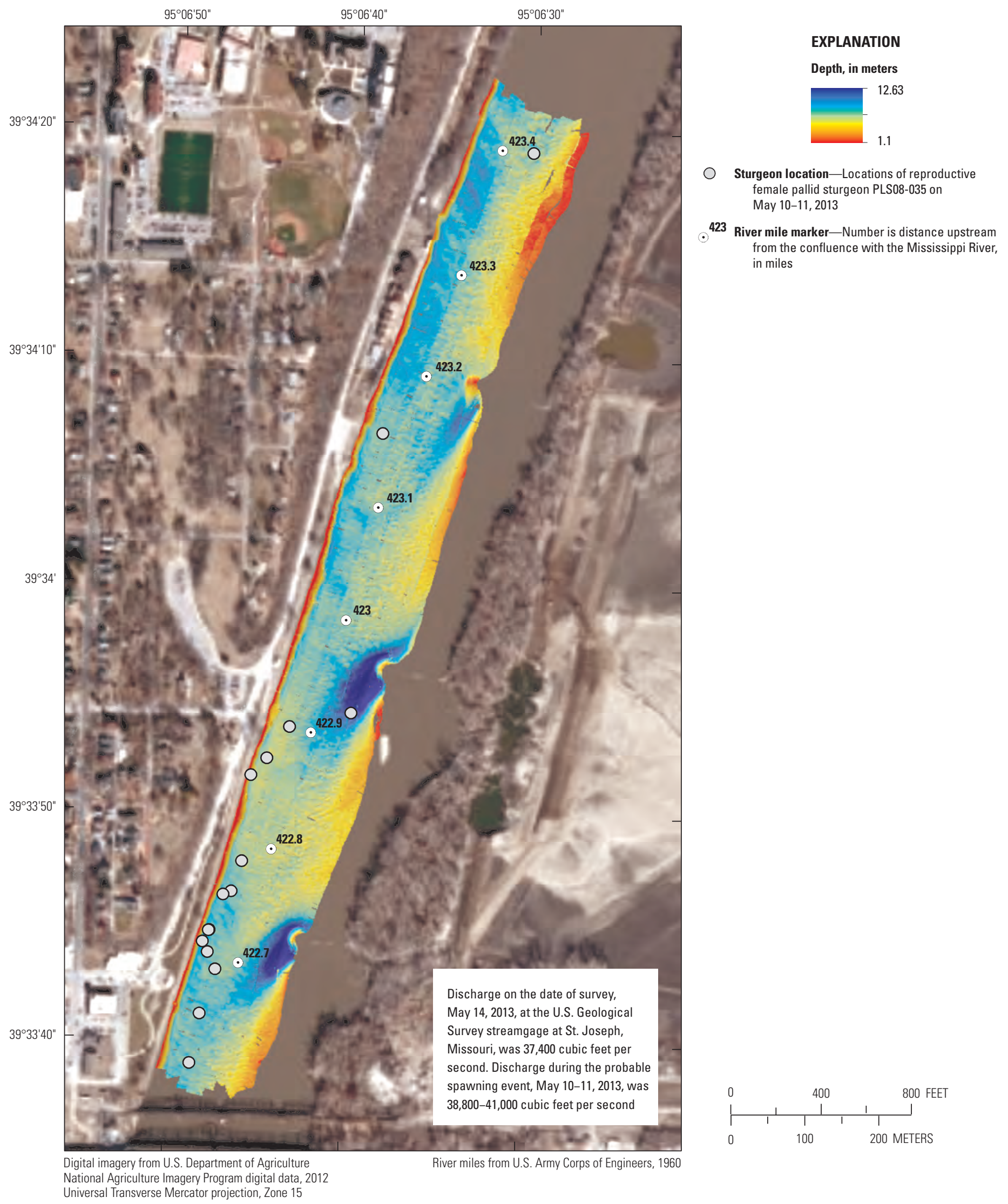

Figure 18. Bathymetric map showing site where pallid sturgeon PLS08-035 spawned on May 10-11, 2013. 


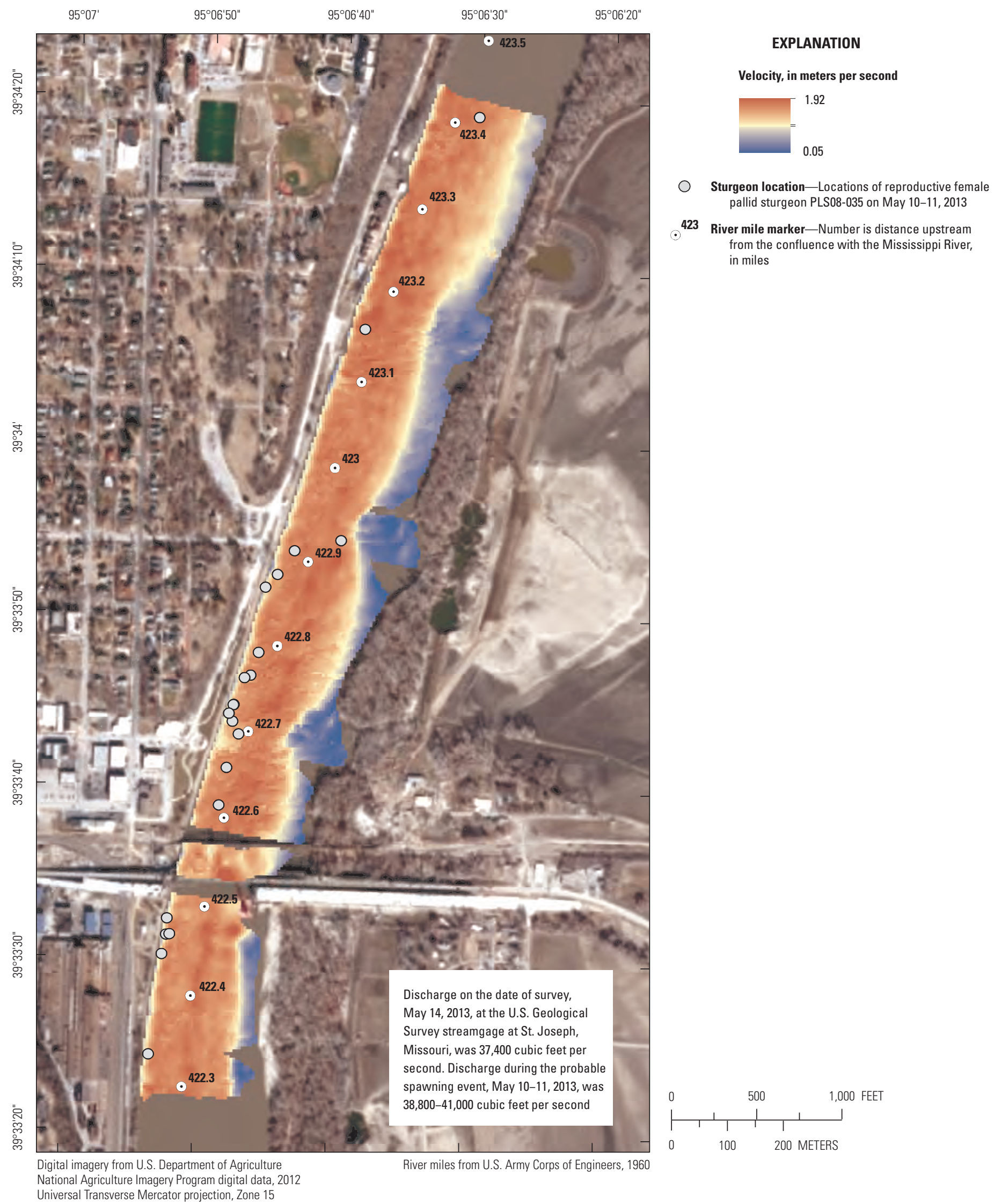

Figure 19. Acoustic Doppler current profiler velocity map showing site where pallid sturgeon PLS08-035 spawned on May 10-11, 2013. 


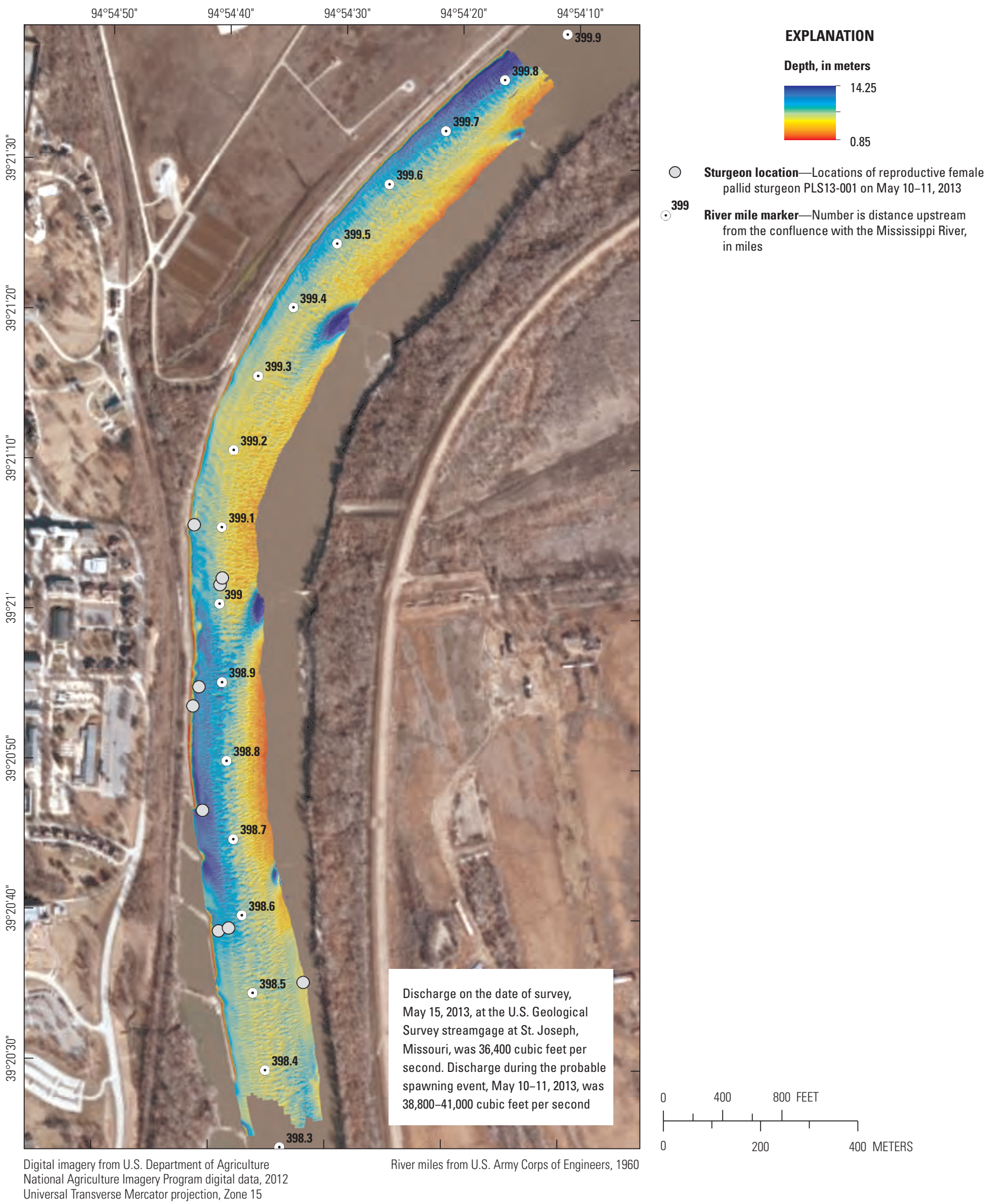

Figure 20. Bathymetric map showing site where pallid sturgeon PLS13-001 spawned on May 10-11, 2013. 


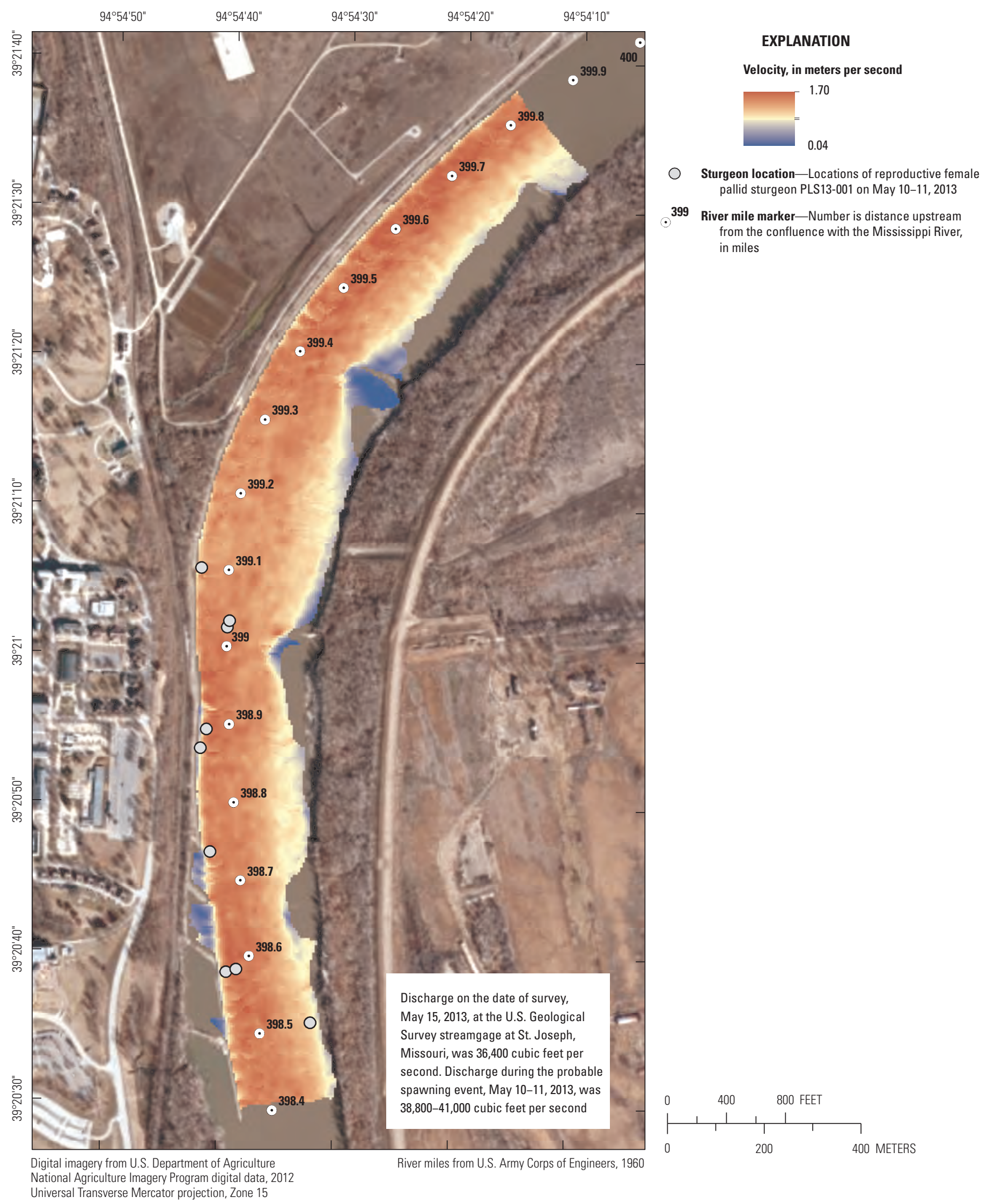

Figure 21. Acoustic Doppler current profiler velocity map showing site where pallid sturgeon PLS13-001 spawned on May 10-11, 2013. 


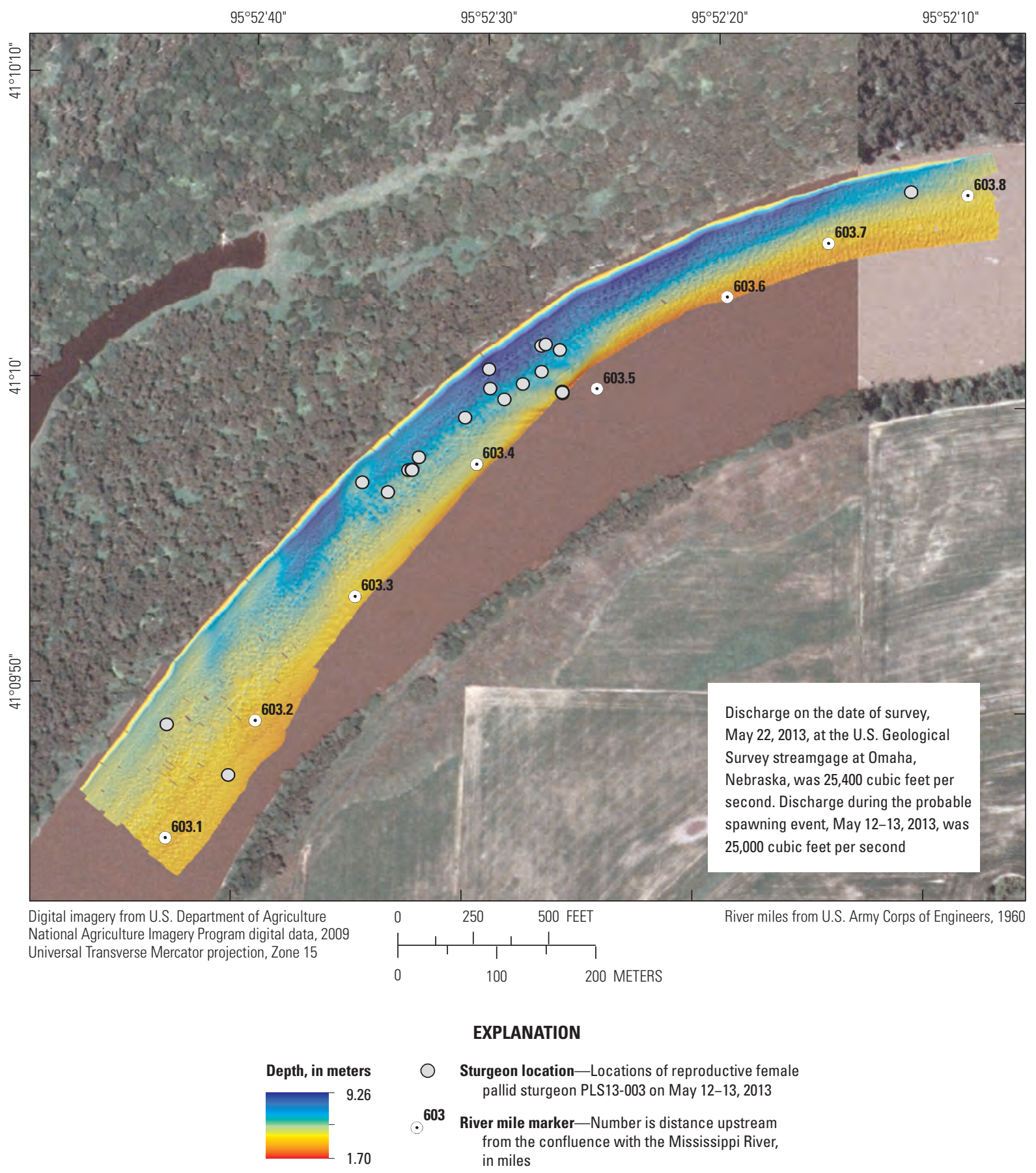

Figure 22. Bathymetric map showing site where pallid sturgeon PLS13-003 spawned on May 12-13, 2013. 


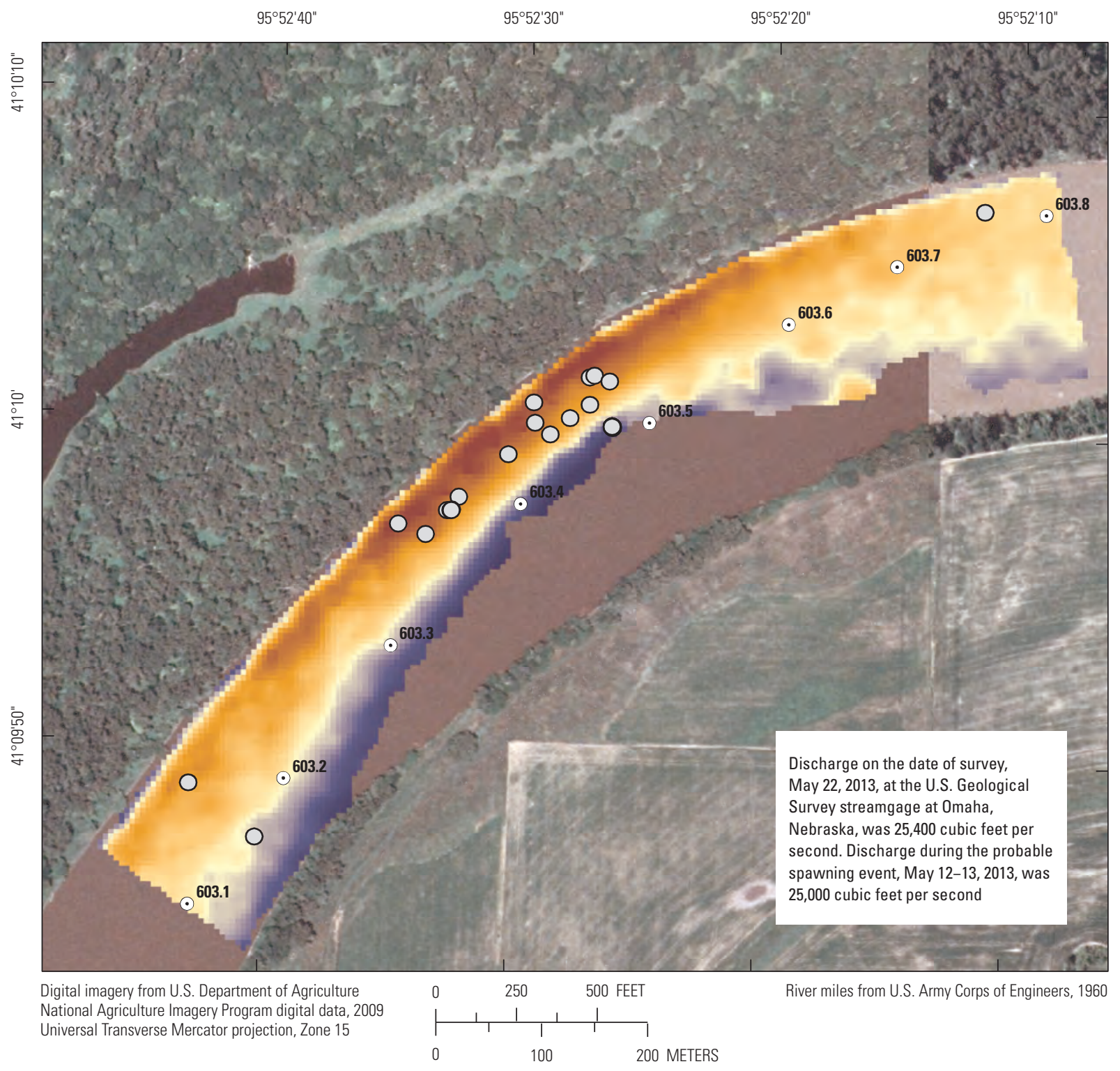

\section{EXPLANATION}

Velocity, in meters per second $\odot \begin{gathered}\text { Sturgeon location—Locations of reproductive female } \\ \text { pallid sturgeon PLS13-003 on May 12-13, 2013 }\end{gathered}$
$=\begin{aligned} & 1.49 \\ & 0.30\end{aligned} \begin{aligned} & \text { 603 } \\ & \text { River mile marker-Number is distance upstream } \\ & \text { from the confluence with the Mississippi River, } \\ & \text { in miles }\end{aligned}$

Figure 23. Acoustic Doppler current profiler velocity map showing site where pallid sturgeon PLS13-003 spawned on May 12-13, 2013. 


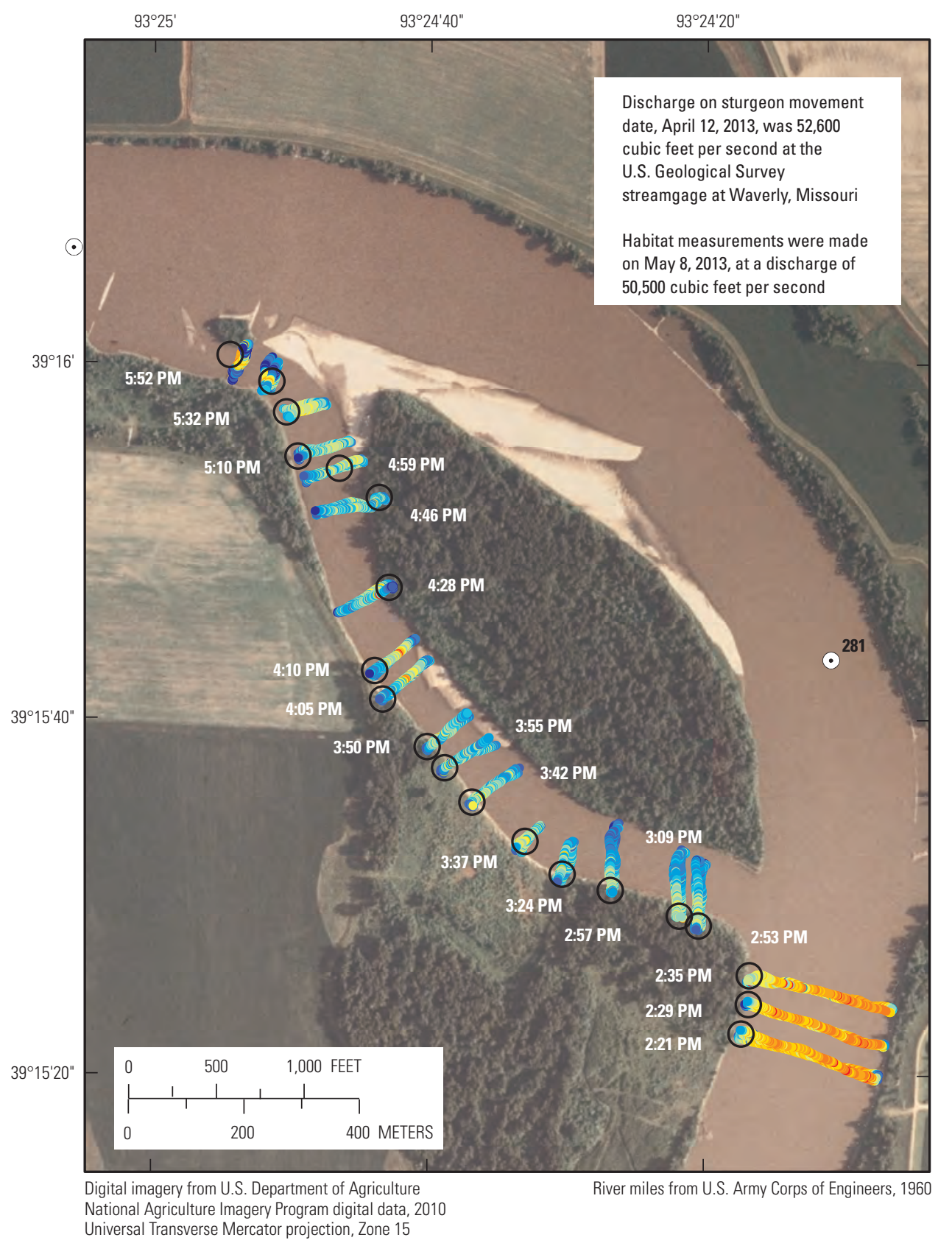

\section{EXPLANATION}

\begin{tabular}{|c|c|c|c|}
\hline \multicolumn{4}{|c|}{ Velocity, in meters per second } \\
\hline & 0.02 to 0.33 & 0 & 0.88 to 0.98 \\
\hline & 0.34 to 0.48 & P & 0.99 to 1.13 \\
\hline & 0.49 to 0.60 & 0 & 1.14 to 1.28 \\
\hline & 0.61 to 0.69 & ○ & 1.29 to 1.43 \\
\hline & 0.70 to 0.78 & - & 1.44 to 1.64 \\
\hline & 0.79 to 0.87 & 0 & 1.65 to 2.78 \\
\hline
\end{tabular}

Sturgeon location-Locations of reproductive female pallid sturgeon PLS11-004 on April 12, 2013

River mile marker-Number is distance upstream from the confluence with the Mississippi River, in miles

Figure 24. Velocities, collected with an acoustic Doppler current profiler, in side chute used by migrating reproductive pallid sturgeon PLS11-004 on April 12, 2013. 
Table 3. Summary data for mapping of 2013 free embryo and larvae sampling sites.

[River mile location gives the approximate mid-point of each survey; discharge is reported as the mean discharge through the course of the survey at the streamgage given in the nearest streamgage column; $\mathrm{ft}^{3} / \mathrm{s}$, cubic foot per second; survey type denotes the methods used for each survey; Nebr., Nebraska; ADCP, acoustic Doppler current profiler]

\begin{tabular}{cclcc}
\hline $\begin{array}{c}\text { Date } \\
\text { (month/day/ } \\
\text { year) }\end{array}$ & $\begin{array}{c}\text { River } \\
\text { mile } \\
\text { location }\end{array}$ & $\begin{array}{c}\text { Nearest } \\
\text { streamgage }\end{array}$ & $\begin{array}{c}\text { Discharge, } \\
\text { in cubic feet } \\
\text { per second } \\
\text { (ft } \mathbf{s}^{3} \text { ) }\end{array}$ & $\begin{array}{c}\text { Survey } \\
\text { type }\end{array}$ \\
\hline $5 / 23 / 2013$ & 599.5 & Omaha, Nebr. & 26,000 & ADCP \\
$5 / 31 / 2013$ & 599.5 & Omaha, Nebr. & 54,900 & ADCP \\
$5 / 31 / 2013$ & 0.2 & Louisville, Nebr. & 17,500 & ADCP \\
\hline
\end{tabular}

We mapped velocities at two free-embryo sampling sites (table 3). The first, located at river mile 599.5, a short distance upstream from the Platte River, was mapped at two discharges - 26,000 and 54,900 ft $3 / \mathrm{s}$. The second larval sampling site, located on the Platte River, approximately $0.2 \mathrm{mi}$ upstream from the confluence with the Missouri River, was mapped at a single discharge $17,500 \mathrm{ft}^{3} / \mathrm{s}$. Our ability to map at the Platte River sampling sites was limited by the shallow flow depths in the Platte River, which prevented our survey boat from traveling in the river during low flows. Figures depicting this data are presented in the following section (see, "Field Studies of Embryo, Larvae, and Young-of-Year Dispersal, Distribution, and Habitat Use").

\section{Analysis of Drift Potential}

Analysis of dispersion coefficients and drift potential is presented in detail in DeLonay and others, (2016); a brief summary of the analysis is presented here. In general, dispersion coefficients derived from ADCP data reflect the distinct geomorphic characteristics and styles of channel engineering used in different segments of the Lower Missouri River. The lowest values of dispersion coefficients are in the Ponca River and Big Sioux River segments where the flow field is homogeneous. Increased topographic and hydraulic complexity within the relatively unaltered Gavins River segment translates into higher dispersion coefficients, reflecting the greater potential for retention of drifting free embryos within this reach. Although the Kansas River and Grand River segments are highly engineered, these segments of river have the highest dispersion coefficients, because large dikes generate pronounced zones of recirculation and strong transverse velocity shear.

\section{Discussion}

Spawning site characteristics are consistent with observations of locations documented in previous years (DeLonay and others, 2016). Although observations are consistent among years the precise location of egg deposition is unknown and therefore the characteristics of spawning substrate selected by pallid sturgeon, and habitat used by developing embryos, are not yet well described.

Drift simulations performed using one-dimensional advection-dispersion equations indicate that passively drifting free embryos may be exported from the Lower Missouri River into the Middle Mississippi River. The analysis, however, assumes drift is entirely passive, an assumption that is contested by limited field data, and the one-dimensional approach neglects the effects of zones of transient storage on retention of drifting larvae. Nonetheless, the model results provide a valuable preliminary estimate of total drift distance along the Lower Missouri River and the analysis highlights the complex local interactions of channel morphology, engineering, and flow regime that control retention and drift of free embryos. The analysis indicated that flow pulses would likely increase downstream advection of drifting pallid sturgeon free embryos, but that higher discharges also have the potential to increase dispersion of drifting free embryos by inundating environments that promote retention.

\section{Field Studies of Embryo, Larvae, and Young-of- Year Dispersal, Distribution, and Habitat Use}

Conservation and recovery of pallid sturgeon, like other imperiled sturgeon, is likely dependent on successful spawning and survival through early life history stages (Anders and others, 2002; Gross and others, 2002; Parsley and others, 2002). Although documentation of spawning by pallid sturgeon is a critical first step towards assessing population status and recovery, successful spawning does not ensure successful recruitment to the juvenile or adult life stages. Rather, biotic and abiotic factors operating during the free-embryo life stage (hatch to endogenous feeding) may limit survival and population growth (Dettlaff and others, 1993). This life stage commonly functions as a recruitment bottleneck for fishes because of decreased mobility and sensory ability, and increased vulnerability to environmental variability and anthropogenic alteration (Scheidegger and Bain, 1995; Humphries and others, 2002). Given the sensitivity of the free-embryo life stage to mortality, it is imperative to identify determinants of posthatch survival in pallid sturgeon. Pallid sturgeon, shovelnose sturgeon, and paddlefish each have adhesive eggs believed to be deposited in the current over coarse substrate, with a protracted free-embryo stage that drifts for several days. Although the species may differ, the comparative examination of the early life stages of the three species may provide insights into factors controlling year class strength or insights into differing patterns of abundance, or rarity. Understanding factors that affect recruitment and composition of sturgeon and paddlefish species, as well as the temporal and spatial dynamics of freeembryo drift will enhance pallid sturgeon recovery efforts.

Recruitment of pallid sturgeon to the adult population is limited or non-existent throughout most of the Missouri River 
(U.S. Fish and Wildlife Service, 2007). Limited numbers of larval and young-of-year sturgeon have been collected from the Lower Missouri River and none have been confirmed as pallid sturgeon using genetic analysis. The low numbers of young sturgeon in Lower Missouri River samples may be explained by limited spawning, lack of successful spawning, poor fertilization, high mortality, ineffective sampling methods, inadequate sampling of drift and settling locations, or rapid dispersal and washout of sturgeon free embryos and larvae from the Missouri River downstream into the Mississippi River.

In the laboratory, shovelnose and pallid sturgeon begin to hatch after 4 to 5 days at $17-18{ }^{\circ} \mathrm{C}$ and drift in natural settings for as many as 6 days or 11-17 days, respectively (Kynard and others, 2007; Braaten and others, 2008). Benthic orientation and the feeding begins near the end of the free-drifting period. The total distance that sturgeon free embryos drift during ontogenetic development is dependent on water velocity, localized hydraulic conditions, and temperature (Kynard and others, 2007; Braaten and others, 2008). Free-embryo sturgeon may require a long segment of free-flowing river to complete the ontogenetic drift and dispersal cycle in the Missouri River (mean velocities $0.4-1.2 \mathrm{~m} / \mathrm{s}$; Reuter and others, 2009) if localized hydraulics do not result in retention of free embryos and larvae in channel margins. The probability of retention in channel margins, rather than direct downstream transport in the thalweg, is an unknown but critical factor in determining total drift distance. The number of sturgeon free embryos and larvae produced in the Lower Missouri River, the proportion retained, and the proportion contributed from major tributaries, is unknown. Locations along the channel where drifting sturgeon embryos are retained, or larvae settle, and the availability of suitable habitat for early feeding, may be critical for survival and recruitment.

The broad objectives of this study were to (1) detect and verify successful spawning, fertilization, hatch, and drift of pallid sturgeon in the Lower Missouri and Platte Rivers, (2) determine the timing and spatial extent of Acipenseriformes spawning in the Lower Missouri and Platte Rivers, (3) assess the species composition of Acipenseriformes embryos in the Lower Missouri and Platte Rivers, and (4) assess the probability of drifting sturgeon to be entrained in shallow water habitats based on the cross-sectional channel distribution and developmental stage of sturgeon collected.

\section{Methods}

To evaluate recruitment and drift dynamics of sturgeon in the Lower Missouri River and the contribution of major tributaries we systematically sampled for Acipenseriformes free embryos at two sites: one site in the main-stem Missouri River upstream from the confluence with the Platte River near river mile 599.5 and the second in the Platte River less than 1 mile from its confluence with the Missouri River (fig. 25). At the Missouri River site, we established a transect with four equidistant sampling stations (stations 10,11,12, and 13) to assess cross-sectional distribution of drifting free embryos (fig. 26). Three sampling stations (numbers 14, 15, and 16) were established in the Platte River less than 1 mile upstream from its confluence with the Missouri River (fig. 27). Sites were systematically sampled for free-drifting embryos 3 days per week from April 30 through July 25, 2013.

Each station was sampled with paired, $0.5-\mathrm{m}$ diameter conical ichthyoplankton nets (750 micrometer mesh) equipped with General Oceanics velocity meters and attached to 100-pound (45.4 kilogram [kg]) Columbus-style sounding weights. Nets were deployed from an anchored 8-m research vessel outfitted with paired booms and winches (port and starboard). In addition, samples were collected at two depths for each station; just above the river bottom and at midwater column unless water depth was less than $2 \mathrm{~m}$. At water depths less than $2 \mathrm{~m}$ we assumed there would be negligible difference between bottom and mid-column samples. Sample duration was intended to be 10 minutes but varied (range $=4-25$ minutes) depending on the suspended load of coarse organic material and debris during the sampling effort. Paired samples were collected in replicate at each sampled station and depth. Ichthyoplankton samples were sorted on board the research vessel shortly after collection. All Acipenseriformes free embryos identified as either pallid sturgeon or shovelnose sturgeon (Scaphirhynchus spp.), or paddlefish (Polyodon spathula) were preserved in 70 percent ethanol for identification to genus in the laboratory. All specimens identified as potential sturgeon free embryos were sent for species determination using genetic analyses at Southern Illinois University Carbondale. For summary and analysis paired, port and starboard, samples were pooled for each depth.

\section{Progress and Results}

A total of 321 net deployments (port and starboard combined) were made from 36 sampling days between April 30 and July 25; 256 among stations 10-13 in the Missouri River and 65 from station 14-16 in the Platte River. Discharge among sampling days ranged from $617-1,246 \mathrm{~m}^{3} / \mathrm{s}$ in the Missouri River (06610000 Missouri River at Omaha, Nebraska) and $34-688 \mathrm{~m}^{3} / \mathrm{s}$ in the Platte River (06805500 Platte River at Louisville, Nebraska). In the interest of safety, samples were not collected the week of May 27th in the Missouri River because of high flows, in excess of $1,700 \mathrm{~m}^{3} / \mathrm{s}$, and heavy debris loads. Samples were not collected June 20th in the Platte River and June 27th in the Missouri River as severe weather impeded larval sampling. Last, samples were not collected the week of July 15 th because water temperatures were in excess of $28^{\circ} \mathrm{C}$ when sturgeon are thought to cease spawning.

A total of 322 sturgeon free embryos was collected during 2013 sampling efforts (table 4). Eleven sturgeon were preliminarily assigned to genus, but were damaged by sampling gear such that a definitive confirmation could only be made through genetic analysis. Genetic analysis confirmed that all sturgeon were shovelnose sturgeon, and none were identified as pallid 

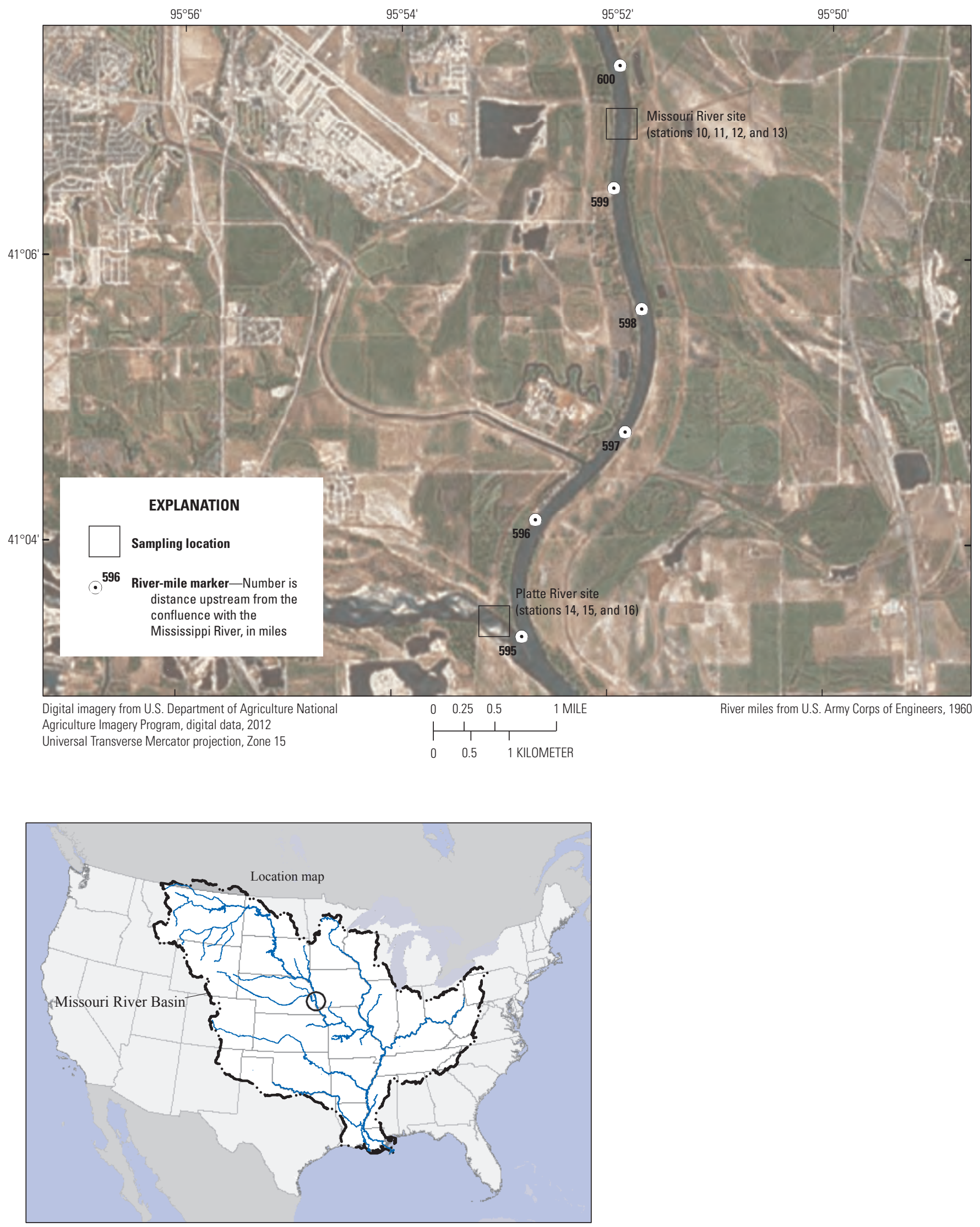

Figure 25. Free-embryo sampling locations in the Lower Missouri River and the Platte River. 

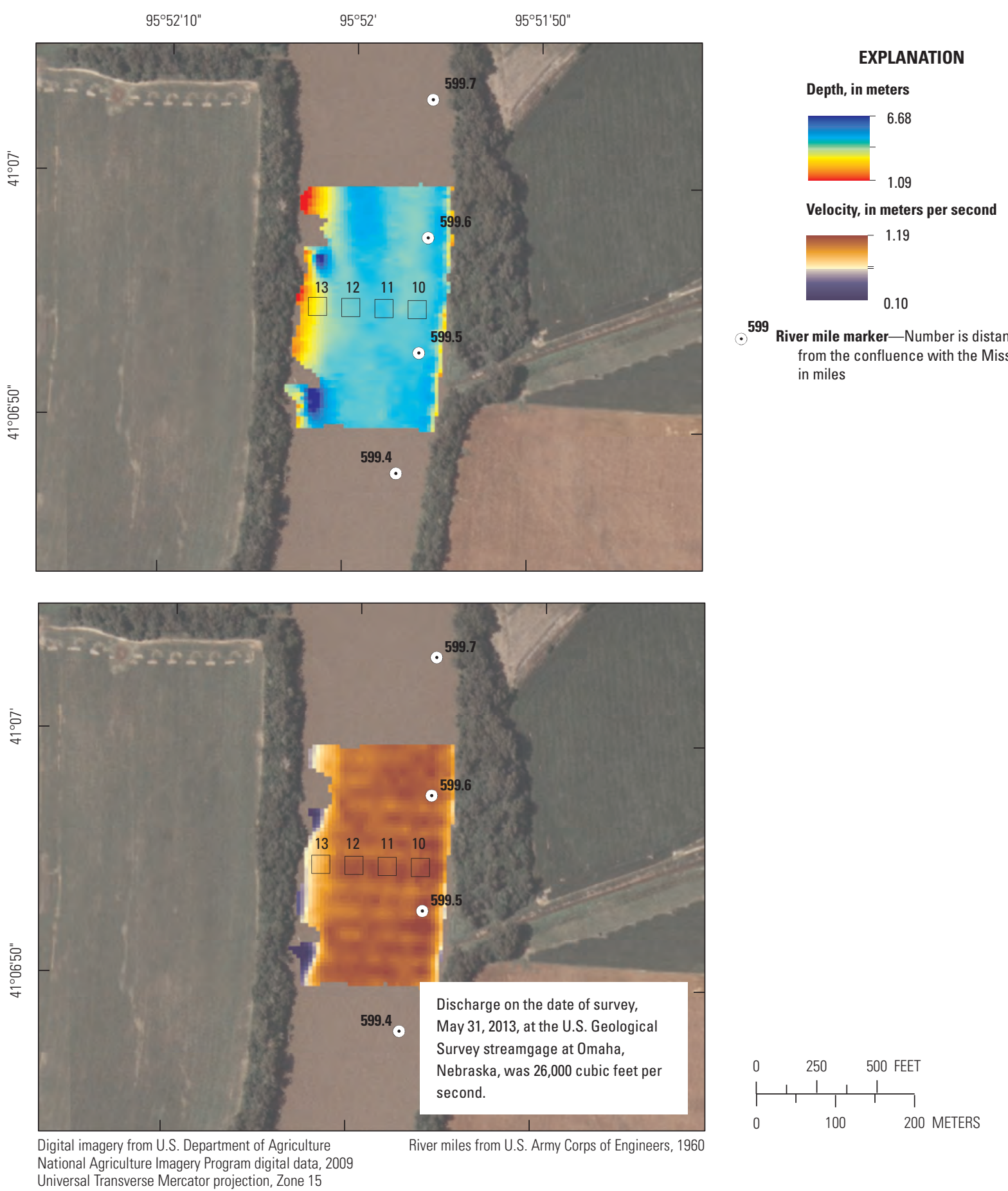

599
River mile marker-Number is distance upstream
from the confluence with the Mississippi River, in miles

Figure 26. Depth and velocity for free embryo and larval sampling transect in the Missouri River near river mile 599.5. 


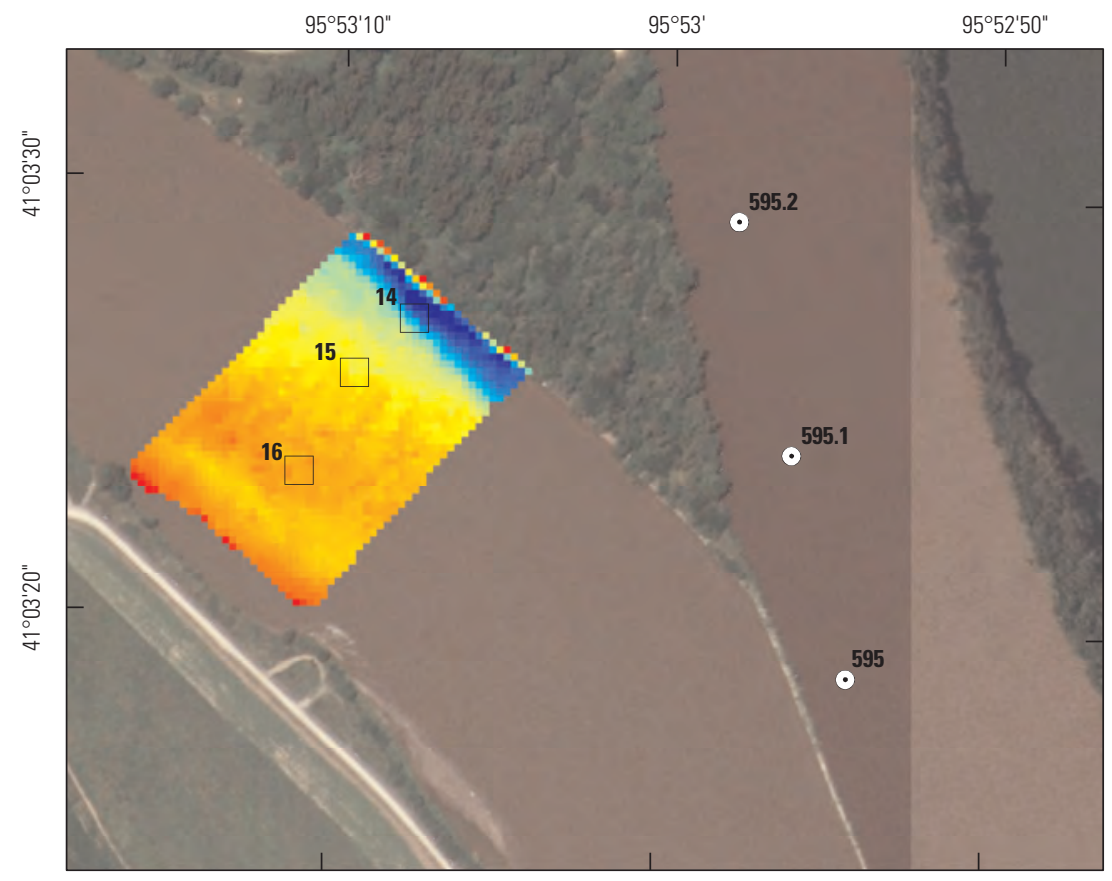

EXPLANATION

Depth, in meters

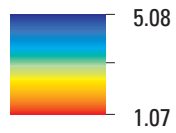

Velocity, in meters per second

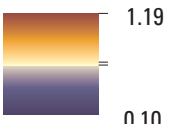

0.10

595 River mile marker-Number is distance upstream from the confluence with the Mississippi River, in miles
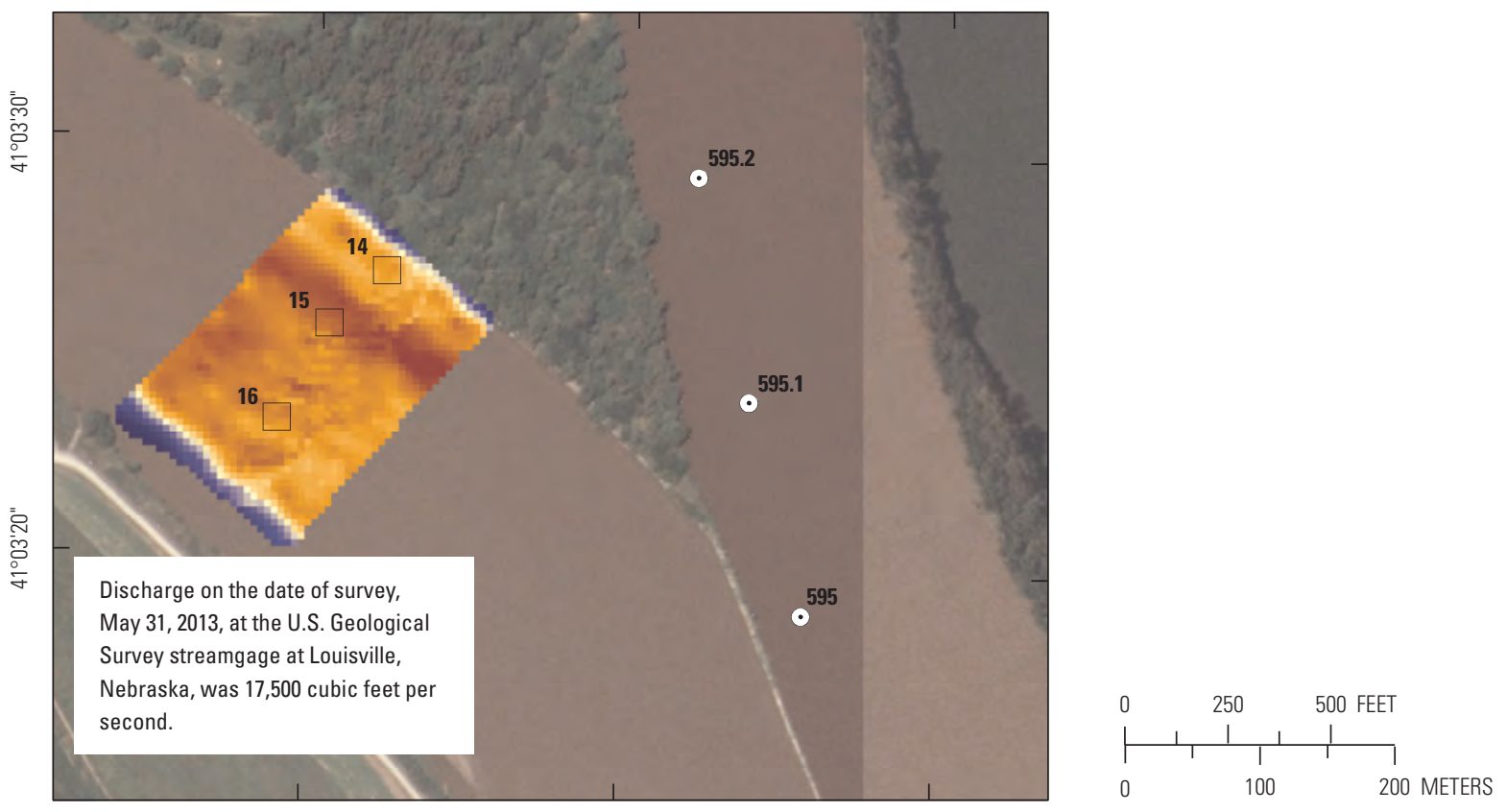

Digital imagery from U.S. Department of Agriculture

River miles from U.S. Army Corps of Engineers, 1960

National Agriculture Imagery Program digital data, 2009

Universal Transverse Mercator projection, Zone 15

Figure 27. Depth and velocity for free embryo and larval sampling transect in the Platte River. 
Table 4. Sampling period, number of sampling days, mean water volume sampled, number and density of sturgeon (Scaphirhynchus spp.) and paddlefish (Polyodon spathula) free embryos and larvae collected during 2013.

\begin{tabular}{cccccccccc}
\hline $\begin{array}{c}\text { Station } \\
\text { number }\end{array}$ & $\begin{array}{c}\text { Station } \\
\text { location }\end{array}$ & $\begin{array}{c}\text { First date } \\
\text { sampled }\end{array}$ & $\begin{array}{c}\text { Last date } \\
\text { sampled }\end{array}$ & $\begin{array}{c}\text { Number } \\
\text { days } \\
\text { sampled }\end{array}$ & $\begin{array}{c}\text { Mean volume } \\
\text { of water } \\
\text { sampled, in } \\
\text { cubic meters }\end{array}$ & $\begin{array}{c}\text { Number } \\
\text { sturgeon } \\
\text { collected }\end{array}$ & $\begin{array}{c}\text { Number } \\
\text { paddlefish } \\
\text { collected }\end{array}$ & $\begin{array}{c}\text { Mean } \\
\text { density of } \\
\text { paddlefish } \\
\text { collected }\end{array}$ & $\begin{array}{c}\text { Mean } \\
\text { density of } \\
\text { sturgeon } \\
\text { collected }\end{array}$ \\
\hline 10 & Missouri River & $4 / 30 / 2013$ & $7 / 25 / 2013$ & 32 & 137.36 & 164 & 28 & 1.25 & 0.15 \\
11 & Missouri River & $4 / 30 / 2013$ & $7 / 25 / 2013$ & 32 & 147.50 & 103 & 59 & 0.73 & 0.36 \\
12 & Missouri River & $4 / 30 / 2013$ & $7 / 25 / 2013$ & 32 & 169.41 & 30 & 9 & 0.20 & 0.05 \\
13 & Missouri River & $4 / 30 / 2013$ & $7 / 25 / 2013$ & 32 & 154.61 & 6 & 0 & 0.04 & 0.00 \\
14 & Platte River & $4 / 30 / 2013$ & $7 / 25 / 2013$ & 35 & 110.61 & 19 & 0 & 0.20 & 0.00 \\
15 & Platte River & $5 / 30 / 2013$ & $5 / 31 / 2013$ & 2 & 50.11 & 0 & 0 & 0.00 & 0.00 \\
16 & Platte River & $5 / 30 / 2013$ & $5 / 31 / 2013$ & 2 & 36.18 & 0 & 0 & 0.00 & 0.00 \\
\hline
\end{tabular}

sturgeon. Of the free embryos identified as sturgeon, 303 were collected in the Missouri River at stations 10-13 (tables 5-8). Sturgeon free embryos initially appeared in Missouri River samples on May 22 at stations 10-12, and were estimated at less than one day post-hatch. The last free-embryo sturgeon was collected July 11 at stations 11 and 12 , and estimated as 0-2 days post-hatch. Discrete water temperatures at Missouri River stations during this time ranged from $17.0^{\circ} \mathrm{C}$ to $27.4{ }^{\circ} \mathrm{C}$. The length of sturgeon free embryos collected during this time ranged from 4.62 millimeters ( $\mathrm{mm}$ ) to $18.02 \mathrm{~mm}$; however, a number of specimens were damaged by the gear yielding some length measurements that were less than total length (TL; fig. 28, tables 5-8). The shortest complete sturgeon specimen was $7.05 \mathrm{~mm}$, estimated as less than 1 day posthatch, collected on June 19th. The remaining 19 sturgeon free embryos were collected in the Platte River at station 14 (tables 9-11). Free-embryo sturgeon initially appeared in Platte River samples on May 15th, and were estimated at less than 1 day post-hatch. The last larval sturgeon from the Platte River appeared on June 11th and was estimated at approximately 2 days post-hatch. Discrete water temperatures at station 14 in the Platte River ranged from $14.5^{\circ} \mathrm{C}$ to $22.3{ }^{\circ} \mathrm{C}$. The length of sturgeon free embryos collected during this time ranged from $6.49 \mathrm{~mm}$ to $11.45 \mathrm{~mm}$, with the shortest complete sturgeon specimen being $7.96 \mathrm{~mm}$ TL (fig. 29, tables 9-12). The oldest sturgeon specimen collected in the Platte River was estimated at 2-3 days post-hatch.

Numbers and mean density of sturgeon free embryos varied among sampling stations (table 12). Across all sampling dates in the Missouri River $(n=32)$, station 10 contained the highest number and mean density of free embryos, 164 and 1.25 free embryos per 100 cubic meters $\left(\mathrm{m}^{3)}\right.$ respectively, followed by station 11, 103 and 0.73 free embryos per $100 \mathrm{~m}^{3}$ (table 12). Mean density of free-embryo sturgeon at the Missouri River site was lowest at station 13 (0.04 free embryos/ $100 \mathrm{~m}^{3}$ ), where only 6 free embryos were collected. Mean density of sturgeon free embryos also was low at station 14 in the Platte River $\left(0.15\right.$ larvae $\left./ 100 \mathrm{~m}^{3}\right)$ where 19 specimens were collected during 35 sampling days. No sturgeon free embryos were collected at stations 15 and 16 in the Platte River during 2 days of sampling.

The periodicity and densities of free embryos sampled during 2013 varied among sampling sites and dates (table 12). Mean densities of free-embryo sturgeon peaked in mid-June in the Missouri River with stations in or near the thalweg having the highest densities. Specifically, the greatest density of free-embryo sturgeon was on June 19th at station 10 with densities of 9.72 free embryos per $100 \mathrm{~m}^{3}$. In the Platte River, free-embryo sturgeon density peaked June 5 th at 3.02 larvae per $100 \mathrm{~m}^{3}$.

A total of 96 paddlefish free embryos was collected during 2013 sampling efforts (table 4). One paddlefish free embryo was preliminarily assigned to genus but was damaged by sampling gear such that a definitive confirmation could only be made through genetic analysis. All 96 specimens identified as paddlefish free embryos were collected in the Missouri River, stations 10-12 (tables 5-8). Paddlefish free embryos appeared in samples on May 14th at station 10, with the last appearing June 19th. Discrete water temperatures at Missouri River stations during this period ranged from $15.7^{\circ} \mathrm{C}$ to $23.2^{\circ} \mathrm{C}$. Paddlefish free-embryo lengths ranged from 7.41 to $14.33 \mathrm{~mm}$ TL (fig. 30, tables 5-8). No paddlefish free embryos were collected in the Platte River.

Paddlefish free embryo numbers and density also varied among sampling stations (table 13). Across all sampling dates in the Missouri River, the highest number $(n=59)$ and mean density $\left(0.36\right.$ free embryos/ $\left.100 \mathrm{~m}^{3}\right)$ of paddlefish free embryos were collected at station 11 , followed by station 10 , (28 and 0.15 larvae $/ 100 \mathrm{~m}^{3}$ ). No paddlefish free embryos were collected at station 13 at the Missouri River site or stations 14, 15 or 16 at the Platte River site. Mean density of paddlefish free embryos collected peaked during late-May at the Missouri River site (table 13). The highest mean density of free-embryo paddlefish was 4.41 free embryos $/ 100 \mathrm{~m}^{3}$ recorded at station 11 on May 22, followed by 2.12 free embryos $/ 100 \mathrm{~m}^{3}$ collected at station 11 and 1.40 free embryos/100 $\mathrm{m}^{3}$ collected at station 10 on May 23 (table 13). 
Table 5. Number, mean length, minimum length, maximum length of free-embryo and larval sturgeon (Scaphirhynchus spp.) and paddlefish (Polyodon spathula) collected in the Missouri River at station 10.

[--, no data]

\begin{tabular}{|c|c|c|c|c|c|c|c|c|}
\hline \multirow[b]{2}{*}{$\begin{array}{c}\text { Collection } \\
\text { date }\end{array}$} & \multicolumn{4}{|c|}{ Sturgeon } & \multicolumn{4}{|c|}{ Paddlefish } \\
\hline & $\begin{array}{l}\text { Number } \\
\text { collected }\end{array}$ & $\begin{array}{c}\text { Mean } \\
\text { length, in } \\
\text { millimeters }\end{array}$ & $\begin{array}{l}\text { Minimum } \\
\text { length, in } \\
\text { millimeters }\end{array}$ & $\begin{array}{l}\text { Maximum } \\
\text { length, in } \\
\text { millimeters }\end{array}$ & $\begin{array}{l}\text { Number } \\
\text { collected }\end{array}$ & $\begin{array}{c}\text { Mean } \\
\text { length, in } \\
\text { millimeters }\end{array}$ & $\begin{array}{l}\text { Minimum } \\
\text { length, in } \\
\text { millimeters }\end{array}$ & $\begin{array}{l}\text { Maximum } \\
\text { length, in } \\
\text { millimeters }\end{array}$ \\
\hline $4 / 30 / 2013$ & -- & -- & -- & -- & -- & -- & -- & -- \\
\hline $5 / 1 / 2013$ & -- & -- & -- & -- & -- & -- & -- & -- \\
\hline $5 / 2 / 2013$ & -- & -- & -- & -- & -- & -- & -- & -- \\
\hline $5 / 7 / 2013$ & -- & -- & -- & -- & -- & -- & -- & -- \\
\hline $5 / 8 / 2013$ & -- & -- & -- & -- & -- & -- & -- & -- \\
\hline $5 / 9 / 2013$ & -- & -- & -- & -- & -- & -- & -- & -- \\
\hline $5 / 14 / 2013$ & -- & -- & -- & -- & 1 & 7.96 & 7.96 & 7.96 \\
\hline $5 / 15 / 2013$ & -- & -- & -- & -- & 7 & 9.27 & 7.69 & 11 \\
\hline $5 / 16 / 2013$ & -- & -- & -- & -- & 4 & 10.56 & 8.37 & 11.46 \\
\hline $5 / 21 / 2013$ & -- & -- & -- & -- & 1 & 14.05 & 14.05 & 14.05 \\
\hline $5 / 22 / 2013$ & 1 & 10.01 & 10.01 & 10.01 & 3 & 11.39 & 8.31 & 13.01 \\
\hline $5 / 23 / 2013$ & 1 & 7.80 & 7.80 & 7.80 & 9 & 10.15 & 8.62 & 12.12 \\
\hline 6/4/2013 & -- & -- & -- & -- & -- & -- & -- & -- \\
\hline 6/5/2013 & 1 & 9.68 & 9.68 & 9.68 & 1 & 11.26 & 11.26 & 11.26 \\
\hline 6/6/2013 & 2 & 10.98 & 8.64 & 13.32 & -- & -- & -- & -- \\
\hline 6/11/2013 & 9 & 11.89 & 9.44 & 15.56 & 1 & 12.32 & 12.32 & 12.32 \\
\hline $6 / 12 / 2013$ & 1 & 11.20 & 11.20 & 11.20 & -- & -- & -- & -- \\
\hline $6 / 13 / 2013$ & 27 & 10.44 & 8.33 & 12.63 & -- & -- & -- & -- \\
\hline $6 / 18 / 2013$ & 30 & 11.15 & 6.02 & 15.56 & -- & -- & -- & -- \\
\hline $6 / 19 / 2013$ & 39 & 11.96 & 7.05 & 15.12 & 1 & 14.33 & 14.33 & 14.33 \\
\hline $6 / 20 / 2013$ & 26 & 13.15 & 9.70 & 17.56 & -- & -- & -- & -- \\
\hline $6 / 25 / 2013$ & 19 & 13.94 & 11.33 & 16.41 & -- & -- & -- & -- \\
\hline $6 / 26 / 2013$ & 6 & 13.70 & 11.87 & 17.08 & -- & -- & -- & -- \\
\hline 7/1/2013 & -- & -- & -- & -- & -- & -- & -- & -- \\
\hline 7/2/2013 & -- & -- & -- & -- & -- & -- & -- & -- \\
\hline 7/3/2013 & 1 & 14.07 & 14.07 & 14.07 & -- & -- & -- & -- \\
\hline 7/9/2013 & 1 & 12.97 & 12.97 & 12.97 & -- & -- & -- & -- \\
\hline 7/10/2013 & -- & -- & -- & -- & -- & -- & -- & -- \\
\hline $7 / 11 / 2013$ & -- & -- & -- & -- & -- & -- & -- & -- \\
\hline 7/23/2013 & -- & -- & -- & -- & -- & -- & -- & -- \\
\hline $7 / 24 / 2013$ & -- & -- & -- & -- & -- & -- & -- & -- \\
\hline $7 / 25 / 2013$ & -- & -- & -- & -- & -- & -- & -- & -- \\
\hline
\end{tabular}


Table 6. Number, mean length, minimum length, maximum length of free-embryo and larval sturgeon (Scaphirhynchus spp.) and paddlefish (Polyodon spathula) collected in the Missouri River at station 11.

[--, no data]

\begin{tabular}{|c|c|c|c|c|c|c|c|c|}
\hline \multirow[b]{2}{*}{$\begin{array}{l}\text { Collection } \\
\text { date }\end{array}$} & \multicolumn{4}{|c|}{ Sturgeon } & \multicolumn{4}{|c|}{ Paddlefish } \\
\hline & $\begin{array}{l}\text { Number } \\
\text { collected }\end{array}$ & $\begin{array}{c}\text { Mean } \\
\text { length, in } \\
\text { millimeters }\end{array}$ & $\begin{array}{l}\text { Minimum } \\
\text { length, in } \\
\text { millimeters }\end{array}$ & $\begin{array}{l}\text { Maximum } \\
\text { length, in } \\
\text { millimeters }\end{array}$ & $\begin{array}{l}\text { Number } \\
\text { collected }\end{array}$ & $\begin{array}{c}\text { Mean } \\
\text { length, in } \\
\text { millimeters }\end{array}$ & $\begin{array}{l}\text { Minimum } \\
\text { length, in } \\
\text { millimeters }\end{array}$ & $\begin{array}{l}\text { Maximum } \\
\text { length, in } \\
\text { millimeters }\end{array}$ \\
\hline $4 / 30 / 2013$ & -- & -- & -- & -- & -- & -- & -- & -- \\
\hline $5 / 1 / 2013$ & -- & -- & -- & -- & -- & -- & -- & -- \\
\hline $5 / 2 / 2013$ & -- & -- & -- & -- & -- & -- & -- & -- \\
\hline $5 / 7 / 2013$ & -- & -- & -- & -- & -- & -- & -- & -- \\
\hline $5 / 8 / 2013$ & -- & -- & -- & -- & -- & -- & -- & -- \\
\hline $5 / 9 / 2013$ & -- & -- & -- & -- & -- & -- & -- & -- \\
\hline $5 / 14 / 2013$ & -- & -- & -- & -- & -- & -- & -- & -- \\
\hline $5 / 15 / 2013$ & -- & -- & -- & -- & 4 & 10.32 & 9.74 & 10.81 \\
\hline $5 / 16 / 2013$ & -- & -- & -- & -- & 6 & 10.03 & 9.06 & 10.82 \\
\hline $5 / 21 / 2013$ & -- & -- & -- & -- & 3 & 12.44 & 10.96 & 13.38 \\
\hline $5 / 22 / 2013$ & 1 & 8.14 & 8.14 & 8.14 & 22 & 11.19 & 6.72 & 13.36 \\
\hline $5 / 23 / 2013$ & 9 & 9.78 & 9.07 & 10.90 & 15 & 11.02 & 7.41 & 13.79 \\
\hline $6 / 4 / 2013$ & 6 & 9.95 & 6.98 & 12.74 & -- & -- & -- & -- \\
\hline $6 / 5 / 2013$ & 5 & 10.74 & 7.73 & 13.13 & 1 & 11.61 & 11.61 & 11.61 \\
\hline $6 / 6 / 2013$ & 4 & 10.94 & 9.79 & 11.81 & 5 & 11.54 & 10.24 & 13.01 \\
\hline $6 / 11 / 2013$ & 7 & 10.55 & 8.89 & 11.16 & 1 & 9.89 & 9.89 & 9.89 \\
\hline $6 / 12 / 2013$ & 4 & 10.52 & 9.62 & 11.40 & 1 & 11.64 & 11.64 & 11.64 \\
\hline $6 / 13 / 2013$ & 24 & 10.94 & 7.56 & 13.64 & 1 & 11.04 & 11.04 & 11.04 \\
\hline $6 / 18 / 2013$ & 12 & 10.34 & 7.56 & 13.22 & -- & -- & -- & -- \\
\hline $6 / 19 / 2013$ & 13 & 12.08 & 9.77 & 13.50 & -- & -- & -- & -- \\
\hline $6 / 20 / 2013$ & 7 & 12.60 & 8.46 & 17.42 & -- & -- & -- & -- \\
\hline $6 / 25 / 2013$ & 5 & 13.07 & 4.62 & 17.33 & -- & -- & -- & -- \\
\hline $6 / 26 / 2013$ & 5 & 14.41 & 10.94 & 16.99 & -- & -- & -- & -- \\
\hline 7/1/2013 & -- & -- & -- & -- & -- & -- & -- & -- \\
\hline $7 / 2 / 2013$ & -- & -- & -- & -- & -- & -- & -- & -- \\
\hline $7 / 3 / 2013$ & -- & -- & -- & -- & -- & -- & -- & -- \\
\hline $7 / 9 / 2013$ & -- & -- & -- & -- & -- & -- & -- & -- \\
\hline $7 / 10 / 2013$ & -- & -- & -- & -- & -- & -- & -- & -- \\
\hline $7 / 11 / 2013$ & 1 & 9.97 & 9.97 & 9.97 & -- & -- & -- & -- \\
\hline $7 / 23 / 2013$ & -- & -- & -- & -- & -- & -- & -- & -- \\
\hline $7 / 24 / 2013$ & -- & -- & -- & -- & -- & -- & -- & -- \\
\hline $7 / 25 / 2013$ & -- & -- & -- & -- & -- & -- & -- & -- \\
\hline
\end{tabular}


Table 7. Number, mean length, minimum length, maximum length of free-embryo and larval sturgeon (Scaphirhynchus spp.) and paddlefish (Polyodon spathula) collected in the Missouri River at station 12.

$[--$, no data $]$

\begin{tabular}{|c|c|c|c|c|c|c|c|c|}
\hline \multirow[b]{2}{*}{$\begin{array}{l}\text { Collection } \\
\text { date }\end{array}$} & \multicolumn{4}{|c|}{ Sturgeon } & \multicolumn{4}{|c|}{ Paddlefish } \\
\hline & $\begin{array}{l}\text { Number } \\
\text { collected }\end{array}$ & $\begin{array}{c}\text { Mean } \\
\text { length, in } \\
\text { millimeters }\end{array}$ & $\begin{array}{l}\text { Minimum } \\
\text { length, in } \\
\text { millimeters }\end{array}$ & $\begin{array}{l}\text { Maximum } \\
\text { length, in } \\
\text { millimeters }\end{array}$ & $\begin{array}{l}\text { Number } \\
\text { collected }\end{array}$ & $\begin{array}{c}\text { Mean } \\
\text { length, in } \\
\text { millimeters }\end{array}$ & $\begin{array}{l}\text { Minimum } \\
\text { length, in } \\
\text { millimeters }\end{array}$ & $\begin{array}{l}\text { Maximum } \\
\text { length, in } \\
\text { millimeters }\end{array}$ \\
\hline $4 / 30 / 2013$ & -- & -- & -- & -- & -- & -- & -- & -- \\
\hline $5 / 1 / 2013$ & -- & -- & -- & -- & -- & -- & -- & -- \\
\hline $5 / 2 / 2013$ & -- & -- & -- & -- & -- & -- & -- & -- \\
\hline $5 / 7 / 2013$ & -- & -- & -- & -- & -- & -- & -- & -- \\
\hline $5 / 8 / 2013$ & -- & -- & -- & -- & -- & -- & -- & -- \\
\hline $5 / 9 / 2013$ & -- & -- & -- & -- & -- & -- & -- & -- \\
\hline $5 / 14 / 2013$ & -- & -- & -- & -- & -- & -- & -- & -- \\
\hline $5 / 15 / 2013$ & -- & -- & -- & -- & 1 & 9.16 & 9.16 & 9.16 \\
\hline $5 / 16 / 2013$ & -- & -- & -- & -- & 1 & 8.89 & 8.89 & 8.89 \\
\hline $5 / 21 / 2013$ & -- & -- & -- & -- & 1 & 13.24 & 13.24 & 13.24 \\
\hline $5 / 22 / 2013$ & 2 & 9.28 & 8.75 & 9.81 & 1 & 9.65 & 9.65 & 9.65 \\
\hline $5 / 23 / 2013$ & 2 & 8.35 & 6.89 & 9.81 & 2 & 10.61 & 9.41 & 11.81 \\
\hline $6 / 4 / 2013$ & -- & -- & -- & -- & -- & -- & -- & -- \\
\hline $6 / 5 / 2013$ & 1 & 8.01 & 8.01 & 8.01 & 2 & 9.89 & 8.22 & 11.55 \\
\hline $6 / 6 / 2013$ & 2 & 9.61 & 7.52 & 11.70 & -- & -- & -- & -- \\
\hline $6 / 11 / 2013$ & 1 & 11.15 & 11.15 & 11.15 & 1 & 8.21 & 8.21 & 8.21 \\
\hline $6 / 12 / 2013$ & 1 & 10.01 & 10.01 & 10.01 & -- & -- & -- & -- \\
\hline $6 / 13 / 2013$ & 5 & 10.51 & 9.67 & 11.30 & -- & -- & -- & -- \\
\hline $6 / 18 / 2013$ & 1 & 16.48 & 16.48 & 16.48 & -- & -- & -- & -- \\
\hline $6 / 19 / 2013$ & 3 & 9.85 & 7.77 & 13.95 & -- & -- & -- & -- \\
\hline $6 / 20 / 2013$ & 4 & 11.91 & 7.88 & 15.84 & -- & -- & -- & -- \\
\hline $6 / 25 / 2013$ & 4 & 13.95 & 10.57 & 16.11 & -- & -- & -- & -- \\
\hline $6 / 26 / 2013$ & 2 & 15.49 & 15.21 & 15.77 & -- & -- & -- & -- \\
\hline $7 / 1 / 2013$ & 1 & 17.32 & 17.32 & 17.32 & -- & -- & -- & -- \\
\hline $7 / 2 / 2013$ & -- & -- & -- & -- & -- & -- & -- & -- \\
\hline $7 / 3 / 2013$ & -- & -- & -- & -- & -- & -- & -- & -- \\
\hline 7/9/2013 & -- & -- & -- & -- & -- & -- & -- & -- \\
\hline $7 / 10 / 2013$ & -- & -- & -- & -- & -- & -- & -- & -- \\
\hline $7 / 11 / 2013$ & 1 & 10.65 & 10.65 & 10.65 & -- & -- & -- & -- \\
\hline $7 / 23 / 2013$ & -- & -- & -- & -- & -- & -- & -- & -- \\
\hline $7 / 24 / 2013$ & -- & -- & -- & -- & -- & -- & -- & -- \\
\hline $7 / 25 / 2013$ & -- & -- & -- & -- & -- & -- & -- & -- \\
\hline
\end{tabular}


Table 8. Number, mean length, minimum length, maximum length of free-embryo and larval sturgeon (Scaphirhynchus spp.) and paddlefish (Polyodon spathula) collected in the Missouri River at station 13.

[--, no data]

\begin{tabular}{|c|c|c|c|c|c|c|c|c|}
\hline \multirow[b]{2}{*}{$\begin{array}{l}\text { Collection } \\
\text { date }\end{array}$} & \multicolumn{4}{|c|}{ Sturgeon } & \multicolumn{4}{|c|}{ Paddlefish } \\
\hline & $\begin{array}{l}\text { Number } \\
\text { collected }\end{array}$ & $\begin{array}{c}\text { Mean } \\
\text { length, in } \\
\text { millimeters }\end{array}$ & $\begin{array}{l}\text { Minimum } \\
\text { length, in } \\
\text { millimeters }\end{array}$ & $\begin{array}{l}\text { Maximum } \\
\text { length, in } \\
\text { millimeters }\end{array}$ & $\begin{array}{l}\text { Number } \\
\text { collected }\end{array}$ & $\begin{array}{c}\text { Mean } \\
\text { length, in } \\
\text { millimeters }\end{array}$ & $\begin{array}{l}\text { Minimum } \\
\text { length, in } \\
\text { millimeters }\end{array}$ & $\begin{array}{l}\text { Maximum } \\
\text { length, in } \\
\text { millimeters }\end{array}$ \\
\hline $4 / 30 / 2013$ & -- & -- & -- & -- & -- & -- & -- & -- \\
\hline $5 / 1 / 2013$ & -- & -- & -- & -- & -- & -- & -- & -- \\
\hline $5 / 2 / 2013$ & -- & -- & -- & -- & -- & -- & -- & -- \\
\hline $5 / 7 / 2013$ & -- & -- & -- & -- & -- & -- & -- & -- \\
\hline $5 / 8 / 2013$ & -- & -- & -- & -- & -- & -- & -- & -- \\
\hline 5/9/2013 & -- & -- & -- & -- & -- & -- & -- & -- \\
\hline $5 / 14 / 2013$ & -- & -- & -- & -- & -- & -- & -- & -- \\
\hline $5 / 15 / 2013$ & -- & -- & -- & -- & -- & -- & -- & -- \\
\hline $5 / 16 / 2013$ & -- & -- & -- & -- & -- & -- & -- & -- \\
\hline $5 / 21 / 2013$ & -- & -- & -- & -- & -- & -- & -- & -- \\
\hline $5 / 22 / 2013$ & -- & -- & -- & -- & -- & -- & -- & -- \\
\hline $5 / 23 / 2013$ & -- & -- & -- & -- & -- & -- & -- & -- \\
\hline $6 / 4 / 2013$ & -- & -- & -- & -- & -- & -- & -- & -- \\
\hline $6 / 5 / 2013$ & -- & -- & -- & -- & -- & -- & -- & -- \\
\hline 6/6/2013 & 1 & 8.57 & 8.57 & 8.57 & -- & -- & -- & -- \\
\hline $6 / 11 / 2013$ & -- & -- & -- & -- & -- & -- & -- & -- \\
\hline $6 / 12 / 2013$ & -- & -- & -- & -- & -- & -- & -- & -- \\
\hline $6 / 13 / 2013$ & -- & -- & -- & -- & -- & -- & -- & -- \\
\hline $6 / 18 / 2013$ & 1 & 8.52 & 8.52 & 8.52 & -- & -- & -- & -- \\
\hline $6 / 19 / 2013$ & 1 & 7.82 & 7.82 & 7.82 & -- & -- & -- & -- \\
\hline $6 / 20 / 2013$ & -- & -- & -- & -- & -- & -- & -- & -- \\
\hline $6 / 25 / 2013$ & 2 & 17.51 & 17.30 & 17.72 & -- & -- & -- & -- \\
\hline 6/26/2013 & -- & -- & -- & -- & -- & -- & -- & -- \\
\hline $7 / 1 / 2013$ & 1 & 18.02 & 18.02 & 18.02 & -- & -- & -- & -- \\
\hline $7 / 2 / 2013$ & -- & -- & -- & -- & -- & -- & -- & -- \\
\hline $7 / 3 / 2013$ & -- & -- & -- & -- & -- & -- & -- & -- \\
\hline 7/9/2013 & -- & -- & -- & -- & -- & -- & -- & -- \\
\hline $7 / 10 / 2013$ & -- & -- & -- & -- & -- & -- & -- & -- \\
\hline $7 / 11 / 2013$ & -- & -- & -- & -- & -- & -- & -- & -- \\
\hline $7 / 23 / 2013$ & -- & -- & -- & -- & -- & -- & -- & -- \\
\hline $7 / 24 / 2013$ & -- & -- & -- & -- & -- & -- & -- & -- \\
\hline $7 / 25 / 2013$ & -- & -- & -- & -- & -- & -- & -- & -- \\
\hline
\end{tabular}




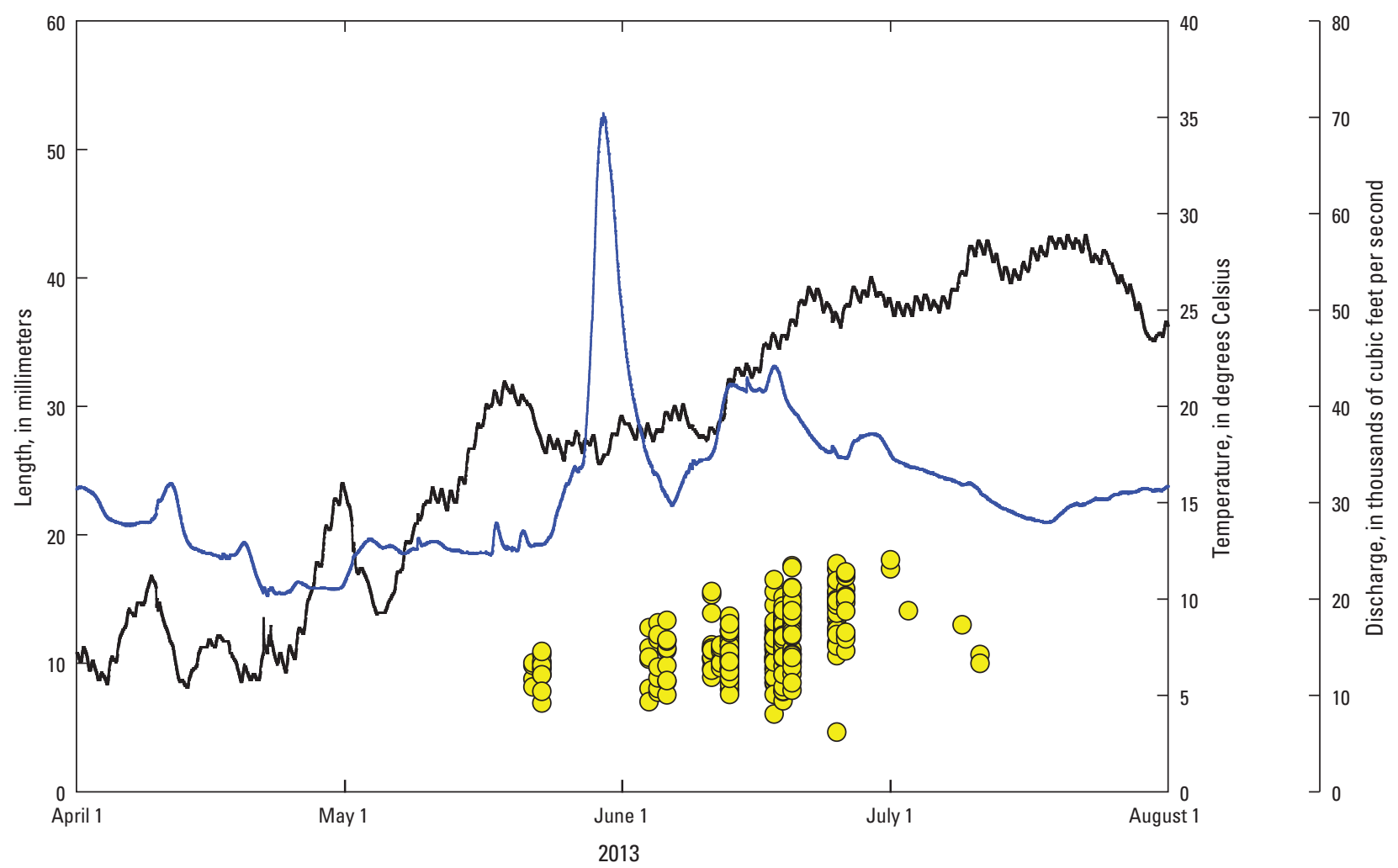

EXPLANATION

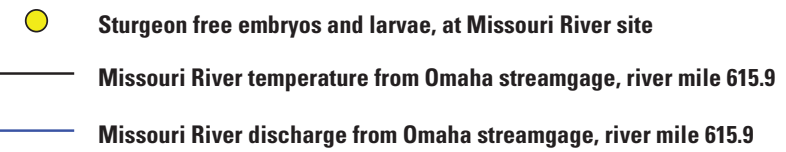

Figure 28. Length of sturgeon (Scaphirhynchus spp.) free embryos and larvae collected at the Missouri River site during 2013. Mean hourly temperature and discharge from the U.S. Geological Survey streamgage near Omaha, Nebraska.

\section{Discussion}

During 2013, most paddlefish free embryos were collected during mid-May to mid-June in the Missouri River; no paddlefish free embryos were found in the Platte River, whereas sturgeon free embryos were collected as late as July 11 (tables 5-10). From free embryo specimens collected, it seems that most sturgeon spawning in the Missouri River appeared to be from mid-May through early-July, whereas sturgeon spawning in the Platte River seemed to be from mid-May through mid-June. As at the St. Charles sampling site during 2012, the highest number and densities of freeembryo sturgeon collected during 2013 were found drifting in and near the thalweg of the Missouri River; therefore, it seems that many free-embryo sturgeon are drifting in or near the thalweg where velocities are highest. These findings support the hypothesis (DeLonay and others, 2009) that sturgeon free embryos may drift long distances and have the potential to drift out of the Lower Missouri River into the Mississippi River.
Despite documentation of spawning by female pallid sturgeon (DeLonay and others, 2009; DeLonay and others, 2010; DeLonay and others, 2012), the relative success of spawning and subsequent hatch in the Lower Missouri River remains largely unknown. To date, only two confirmed pallid sturgeon free embryos have been collected in the Upper Missouri River and none in the Lower Missouri River (Heist and Eichelberger, 2013), suggesting that natural spawning, hatch, or both are severely limited.

\section{Data Coordination, Integration, Geospatial Analysis and Outreach}

The basic functionality of a data management system includes data collection, integration, and retrieval (Wruck and others, 2012). These elements are essential for data completeness, accuracy, and accessibility for complex and multiyear projects such as the Comprehensive Sturgeon Research Project. The large-scale of the CSRP covers more than 800 miles of the Lower Missouri River and involves 
Table 9. Number, mean length, minimum length, maximum length of free-embryo and larval sturgeon (Scaphirhynchus spp.) and paddlefish (Polyodon spathula) collected in the Platte River at station 14.

[--, no data]

\begin{tabular}{|c|c|c|c|c|c|c|c|c|}
\hline \multirow[b]{2}{*}{$\begin{array}{c}\text { Collection } \\
\text { date }\end{array}$} & \multicolumn{4}{|c|}{ Sturgeon } & \multicolumn{4}{|c|}{ Paddlefish } \\
\hline & $\begin{array}{l}\text { Number } \\
\text { collected }\end{array}$ & $\begin{array}{c}\text { Mean } \\
\text { length, in } \\
\text { millimeters }\end{array}$ & $\begin{array}{l}\text { Minimum } \\
\text { length, in } \\
\text { millimeters }\end{array}$ & $\begin{array}{l}\text { Maximum } \\
\text { length, in } \\
\text { millimeters }\end{array}$ & $\begin{array}{l}\text { Number } \\
\text { collected }\end{array}$ & $\begin{array}{c}\text { Mean } \\
\text { length, in } \\
\text { millimeters }\end{array}$ & $\begin{array}{l}\text { Minimum } \\
\text { length, in } \\
\text { millimeters }\end{array}$ & $\begin{array}{l}\text { Maximum } \\
\text { length, in } \\
\text { millimeters }\end{array}$ \\
\hline 4/30/2013 & -- & -- & -- & -- & -- & -- & -- & -- \\
\hline $5 / 1 / 2013$ & -- & -- & -- & -- & -- & -- & -- & -- \\
\hline $5 / 2 / 2013$ & -- & -- & -- & -- & -- & -- & -- & -- \\
\hline $5 / 7 / 2013$ & -- & -- & -- & -- & -- & -- & -- & -- \\
\hline $5 / 8 / 2013$ & -- & -- & -- & -- & -- & -- & -- & -- \\
\hline $5 / 9 / 2013$ & -- & -- & -- & -- & -- & -- & -- & -- \\
\hline $5 / 14 / 2013$ & -- & -- & -- & -- & -- & -- & -- & -- \\
\hline $5 / 15 / 2013$ & 1 & 7.97 & 7.97 & 7.97 & -- & -- & -- & -- \\
\hline $5 / 16 / 2013$ & -- & -- & -- & -- & -- & -- & -- & -- \\
\hline $5 / 21 / 2013$ & -- & -- & -- & -- & -- & -- & -- & -- \\
\hline $5 / 22 / 2013$ & -- & -- & -- & -- & -- & -- & -- & -- \\
\hline $5 / 23 / 2013$ & -- & -- & -- & -- & -- & -- & -- & -- \\
\hline $5 / 29 / 2013$ & -- & -- & -- & -- & -- & -- & -- & -- \\
\hline $5 / 30 / 2013$ & -- & -- & -- & -- & -- & -- & -- & -- \\
\hline $5 / 31 / 2013$ & 2 & 10.27 & 9.51 & 11.02 & -- & -- & -- & -- \\
\hline 6/4/2013 & -- & -- & -- & -- & -- & -- & -- & -- \\
\hline 6/5/2013 & 8 & 9.06 & 7.96 & 10.12 & -- & -- & -- & -- \\
\hline 6/6/2013 & 7 & 8.88 & 6.49 & 10.70 & -- & -- & -- & -- \\
\hline $6 / 11 / 2013$ & 1 & 11.45 & 11.45 & 11.45 & -- & -- & -- & -- \\
\hline $6 / 12 / 2013$ & -- & -- & -- & -- & -- & -- & -- & -- \\
\hline 6/13/2013 & -- & -- & -- & -- & -- & -- & -- & -- \\
\hline 6/18/2013 & -- & -- & -- & -- & -- & -- & -- & -- \\
\hline 6/19/2013 & -- & -- & -- & -- & -- & -- & -- & -- \\
\hline $6 / 25 / 2013$ & -- & -- & -- & -- & -- & -- & -- & -- \\
\hline 6/26/2013 & -- & -- & -- & -- & -- & -- & -- & -- \\
\hline 6/27/2013 & -- & -- & -- & -- & -- & -- & -- & -- \\
\hline 7/1/2013 & -- & -- & -- & -- & -- & -- & -- & -- \\
\hline 7/2/2013 & -- & -- & -- & -- & -- & -- & -- & -- \\
\hline 7/3/2013 & -- & -- & -- & -- & -- & -- & -- & -- \\
\hline 7/9/2013 & -- & -- & -- & -- & -- & -- & -- & -- \\
\hline $7 / 10 / 2013$ & -- & -- & -- & -- & -- & -- & -- & -- \\
\hline $7 / 11 / 2013$ & -- & -- & -- & -- & -- & -- & -- & -- \\
\hline $7 / 23 / 2013$ & -- & -- & -- & -- & -- & -- & -- & -- \\
\hline $7 / 24 / 2013$ & -- & -- & -- & -- & -- & -- & -- & -- \\
\hline $7 / 25 / 2013$ & -- & -- & -- & -- & -- & -- & -- & -- \\
\hline
\end{tabular}


Table 10. Number, mean length, minimum length, maximum length of free-embryo and larval sturgeon (Scaphirhynchus spp.) and paddlefish (Polyodon spathula) collected in the Platte River at station 15.

[--, no data]

\begin{tabular}{|c|c|c|c|c|c|c|c|c|}
\hline \multirow[b]{2}{*}{$\begin{array}{l}\text { Collection } \\
\text { date }\end{array}$} & \multicolumn{4}{|c|}{ Sturgeon } & \multicolumn{4}{|c|}{ Paddlefish } \\
\hline & $\begin{array}{l}\text { Number } \\
\text { collected }\end{array}$ & $\begin{array}{c}\text { Mean } \\
\text { length, in } \\
\text { millimeters }\end{array}$ & $\begin{array}{l}\text { Minimum } \\
\text { length, in } \\
\text { millimeters }\end{array}$ & $\begin{array}{l}\text { Maximum } \\
\text { length, in } \\
\text { millimeters }\end{array}$ & $\begin{array}{l}\text { Number } \\
\text { collected }\end{array}$ & $\begin{array}{c}\text { Mean } \\
\text { length, in } \\
\text { millimeters }\end{array}$ & $\begin{array}{l}\text { Minimum } \\
\text { length, in } \\
\text { millimeters }\end{array}$ & $\begin{array}{l}\text { Maximum } \\
\text { length, in } \\
\text { millimeters }\end{array}$ \\
\hline $5 / 30 / 2013$ & -- & -- & -- & -- & -- & -- & -- & -- \\
\hline $5 / 31 / 2013$ & -- & -- & -- & -- & -- & -- & -- & -- \\
\hline
\end{tabular}

Table 11. Number, mean length, minimum length, maximum length of free-embryo and larval sturgeon (Scaphirhynchus spp.) and paddlefish (Polyodon spathula) collected in the Platte River at station 16.

[--, no data]

\begin{tabular}{|c|c|c|c|c|c|c|c|c|}
\hline \multirow[b]{2}{*}{$\begin{array}{l}\text { Collection } \\
\text { date }\end{array}$} & \multicolumn{4}{|c|}{ Sturgeon } & \multicolumn{4}{|c|}{ Paddlefish } \\
\hline & $\begin{array}{l}\text { Number } \\
\text { collected }\end{array}$ & $\begin{array}{c}\text { Mean } \\
\text { length, in } \\
\text { millimeters }\end{array}$ & $\begin{array}{l}\text { Minimum } \\
\text { length, in } \\
\text { millimeters }\end{array}$ & $\begin{array}{l}\text { Maximum } \\
\text { length, in } \\
\text { millimeters }\end{array}$ & $\begin{array}{l}\text { Number } \\
\text { collected }\end{array}$ & $\begin{array}{c}\text { Mean } \\
\text { length, in } \\
\text { millimeters }\end{array}$ & $\begin{array}{l}\text { Minimum } \\
\text { length, in } \\
\text { millimeters }\end{array}$ & $\begin{array}{l}\text { Maximum } \\
\text { length, in } \\
\text { millimeters }\end{array}$ \\
\hline $5 / 30 / 2013$ & -- & -- & -- & -- & -- & -- & -- & -- \\
\hline $5 / 31 / 2013$ & -- & -- & -- & -- & -- & -- & -- & -- \\
\hline
\end{tabular}

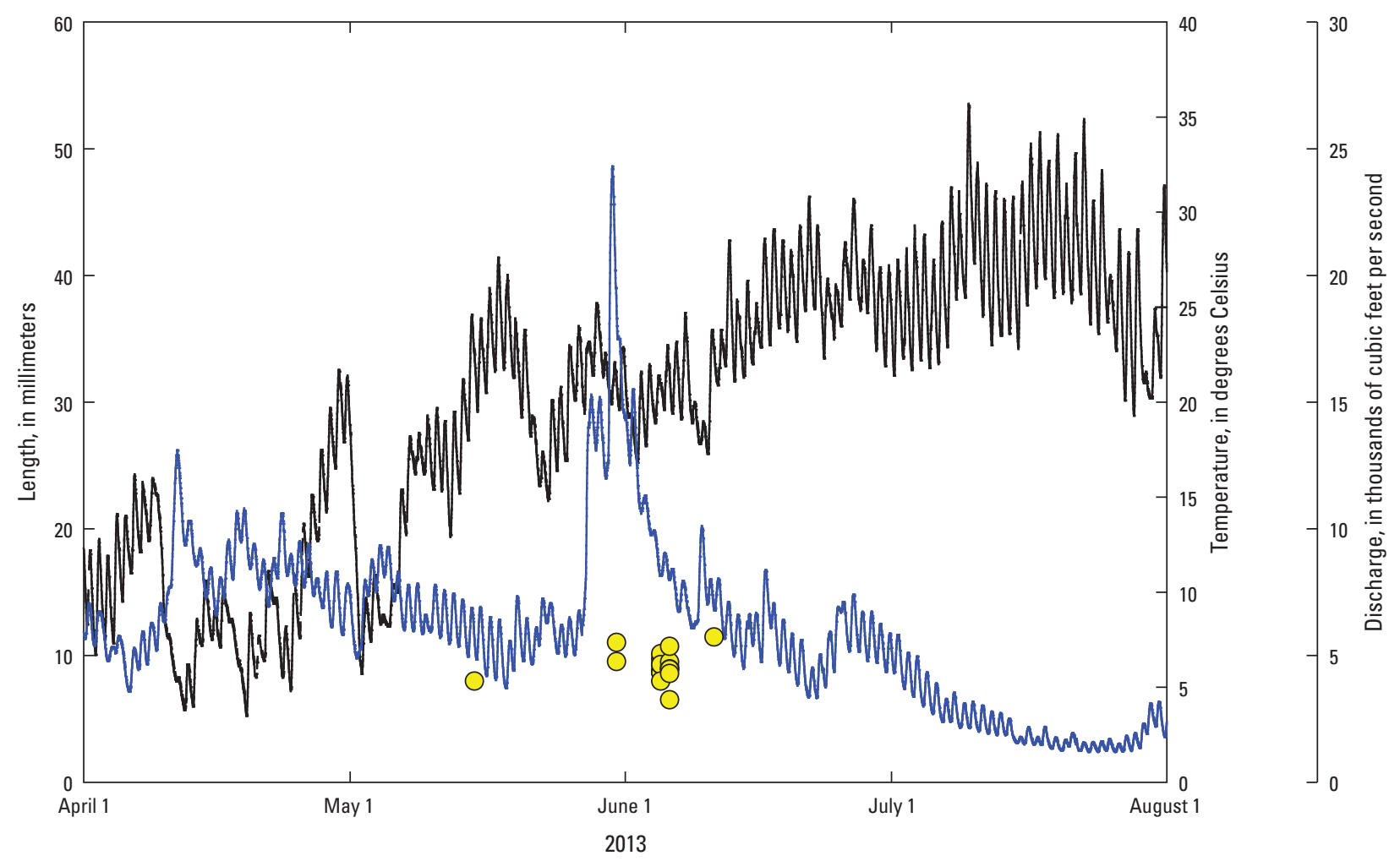

EXPLANATION

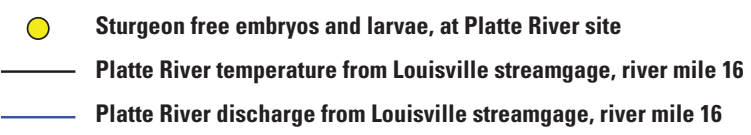

Figure 29. Length of sturgeon (Scaphirhynchus spp.) free embryos and larvae collected at the Platte River site during 2013. Mean hourly temperature and discharge from the U.S. Geological Survey streamgage near Omaha, Nebraska. 


\section{0}

Ecological Requirements for Pallid Sturgeon Reproduction and Recruitment in the Missouri River-Annual Report 2013

Table 12. Mean density, number per 100 cubic meters, of sturgeon (Scaphirhynchus spp.) free embryos and larvae per sampling day. $[--$, no data $]$

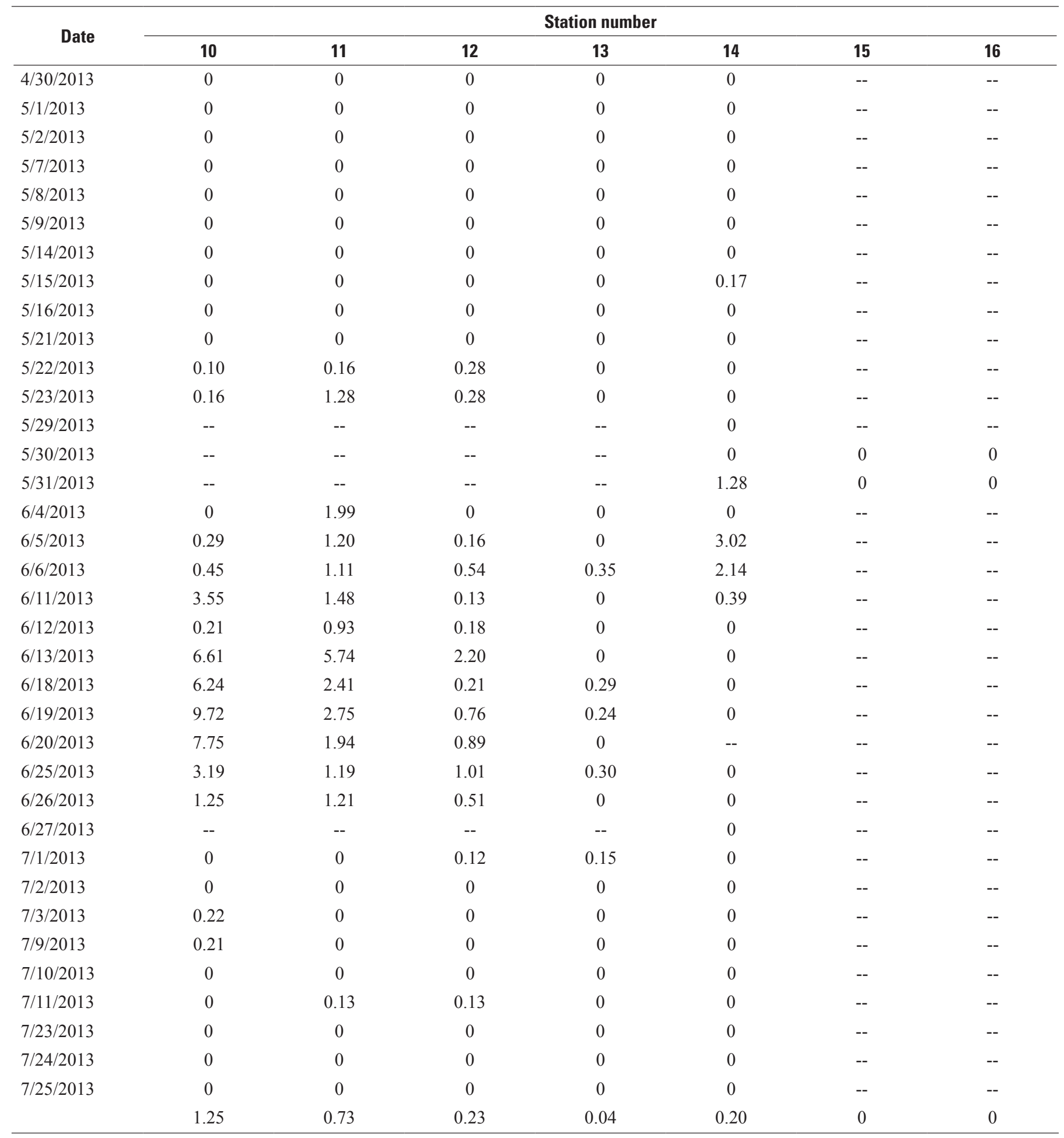




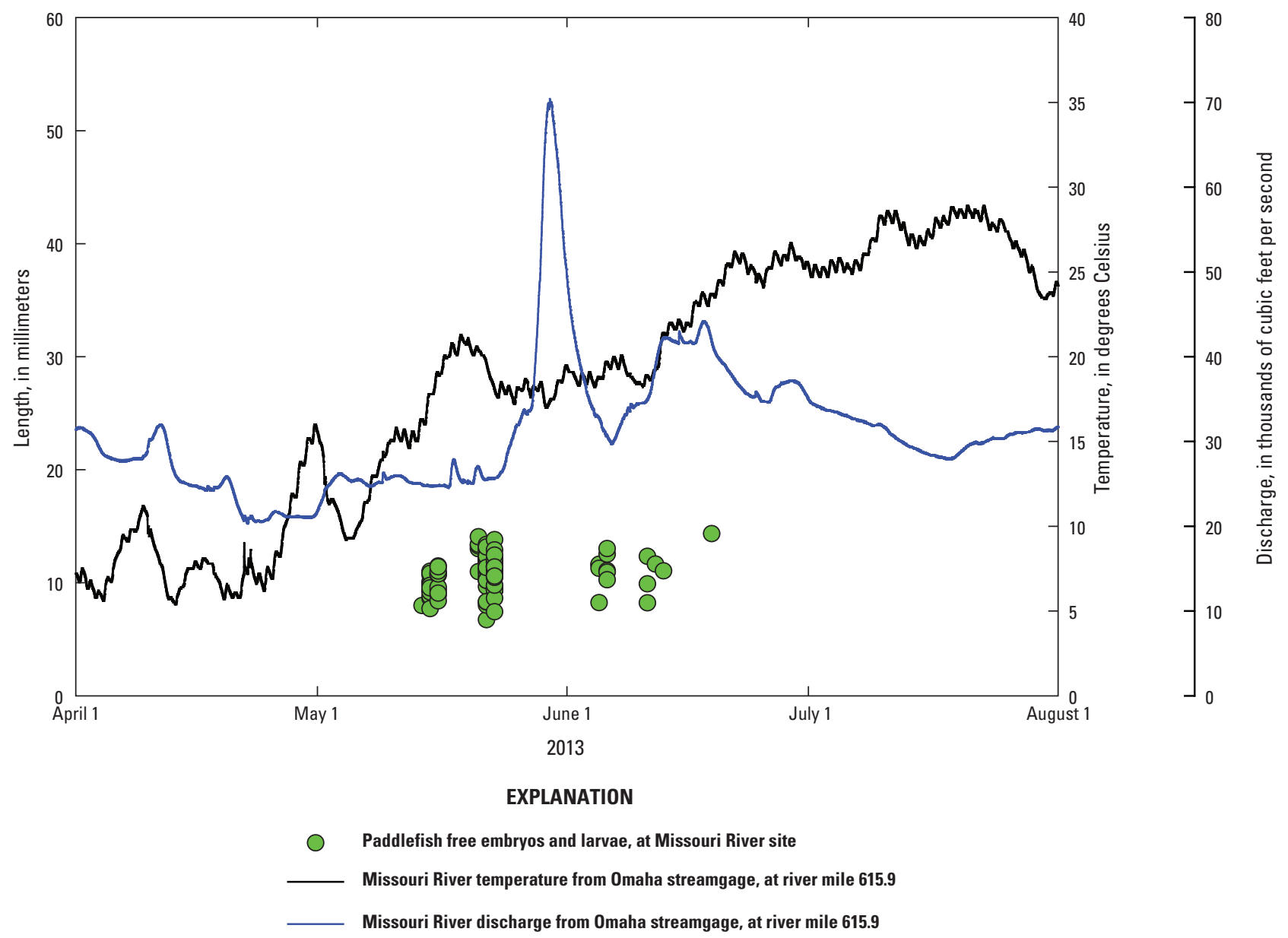

Figure 30. Length of paddlefish (Polyodon spathula) free embryos and larvae collected at the Missouri River site during 2013. Mean hourly temperature and discharge from the U.S. Geological Survey streamgage near Omaha, Nebraska

simultaneous collection of geospatial telemetry data by multiple field personnel and thus requires standardized and streamlined data collection methods. Furthermore, the research activities of the CSRP generates large volumes of tabular data related to sturgeon sampling, morphology, meristics, surgical implantations, reproductive assessments, and environmental variables. Data to support CSRP research originate in disparate physical locations and frequently in very different data formats (for example, ESRI shape files, text files, and comma delimited files). As the CSRP is a multiagency collaborative effort developed to provide information and Missouri River management decisions, a mechanism was needed to simplify the compilation of the many disparate datasets. Therefore, the CSRP developed a Sturgeon Information Management System (SIMS) as a central and unifying platform to collect, maintain, organize, integrate, and explore the rich and diverse datastream collected by multiple partners.

The general objectives of this task have been to (1) develop and maintain a standardized mobile mapping and electronic data-collection framework to support simultaneous geospatial data collection from multiple research crews; (2) establish reliable data transfer mechanisms; (3) compile, integrate, and maintain data collected for CSRP; and (4) develop and maintain near real-time data reporting.

\section{Methods}

The SIMS accommodates and integrates multiple disparate data types by using a suite of software to accommodate various data formats and the demand for near real-time updates (fig. 31). The SIMS mobile mapping application was used to rapidly and accurately collect real-time geospatial telemetry data. The application was developed using $\operatorname{ArcPad} \AA$ (ESRI, Redlands, Calif.) and deployed on ruggedized laptop computers. The SIMS application contained all the customized tools, data layers and data entry forms to streamline the collection of two types of data, search effort and sturgeon telemetry observation datasets. A series of custom edit forms guide a user through a typical telemetry observation session. The edit forms prompt the observer to record information identifying a particular fish (based on acoustic tag number and frequency) and enable the observer to describe the water quality, hydrologic conditions, habitat, and substrate. Field data are input from drop-down menus or by using the keyboard for text 
Table 13. Mean density, number per 100 cubic meters, of paddlefish (Polyodon spathula) free embryos and larvae per sampling day. [--, no data]

\begin{tabular}{|c|c|c|c|c|c|c|c|}
\hline \multirow{2}{*}{ Date } & \multicolumn{7}{|c|}{ Station number } \\
\hline & 10 & 11 & 12 & 13 & 14 & 15 & 16 \\
\hline $4 / 30 / 2013$ & 0 & 0 & 0 & 0 & 0 & -- & -- \\
\hline $5 / 1 / 2013$ & 0 & 0 & 0 & 0 & 0 & -- & -- \\
\hline $5 / 2 / 2013$ & 0 & 0 & 0 & 0 & 0 & -- & -- \\
\hline $5 / 7 / 2013$ & 0 & 0 & 0 & 0 & 0 & -- & -- \\
\hline $5 / 8 / 2013$ & 0 & 0 & 0 & 0 & 0 & -- & -- \\
\hline 5/9/2013 & 0 & 0 & 0 & 0 & 0 & -- & -- \\
\hline $5 / 14 / 2013$ & 0.16 & 0 & 0 & 0 & 0 & -- & -- \\
\hline $5 / 15 / 2013$ & 1.14 & 0.66 & 0 & 0 & 0 & -- & -- \\
\hline $5 / 16 / 2013$ & 0.61 & 0.95 & 0.15 & 0 & 0 & -- & -- \\
\hline $5 / 21 / 2013$ & 0 & 1.20 & 0.29 & 0 & 0 & -- & -- \\
\hline $5 / 22 / 2013$ & 0.38 & 4.41 & 0.14 & 0 & 0 & -- & -- \\
\hline $5 / 23 / 2013$ & 1.40 & 2.12 & 0.26 & 0 & 0 & -- & -- \\
\hline $5 / 29 / 2013$ & -- & -- & -- & -- & 0 & -- & -- \\
\hline $5 / 30 / 2013$ & -- & -- & -- & -- & 0 & 0 & 0 \\
\hline $5 / 31 / 2013$ & -- & -- & -- & -- & 0 & 0 & 0 \\
\hline 6/4/2013 & 0 & 0 & 0 & 0 & 0 & -- & -- \\
\hline 6/5/2013 & 0.26 & 0.28 & 0.29 & 0 & 0 & -- & -- \\
\hline 6/6/2013 & 0 & 1.39 & 0 & 0 & 0 & -- & -- \\
\hline $6 / 11 / 2013$ & 0.38 & 0.15 & 0.15 & 0 & 0 & -- & -- \\
\hline 6/12/2013 & 0 & 0.21 & 0 & 0 & 0 & -- & -- \\
\hline $6 / 13 / 2013$ & 0 & 0 & 0 & 0 & 0 & -- & -- \\
\hline $6 / 18 / 2013$ & 0 & 0 & 0 & 0 & 0 & -- & -- \\
\hline $6 / 19 / 2013$ & 0.26 & 0 & 0 & 0 & 0 & -- & -- \\
\hline $6 / 20 / 2013$ & 0 & 0 & 0 & 0 & -- & -- & -- \\
\hline $6 / 25 / 2013$ & 0 & 0 & 0 & 0 & 0 & -- & -- \\
\hline $6 / 26 / 2013$ & 0 & 0 & 0 & 0 & 0 & -- & -- \\
\hline $6 / 27 / 2013$ & -- & -- & -- & -- & 0 & -- & -- \\
\hline 7/1/2013 & 0 & 0 & 0 & 0 & 0 & -- & -- \\
\hline 7/2/2013 & 0 & 0 & 0 & 0 & 0 & -- & -- \\
\hline $7 / 3 / 2013$ & 0 & 0 & 0 & 0 & 0 & -- & -- \\
\hline 7/9/2013 & 0 & 0 & 0 & 0 & 0 & -- & -- \\
\hline 7/10/2013 & 0 & 0 & 0 & 0 & 0 & -- & -- \\
\hline $7 / 11 / 2013$ & 0 & 0 & 0 & 0 & 0 & -- & -- \\
\hline $7 / 23 / 2013$ & 0 & 0 & 0 & 0 & 0 & -- & -- \\
\hline $7 / 24 / 2013$ & 0 & 0 & 0 & 0 & 0 & -- & -- \\
\hline \multirow[t]{2}{*}{$7 / 25 / 2013$} & 0 & 0 & 0 & 0 & 0 & -- & -- \\
\hline & 0.15 & 0.36 & 0.04 & 0.00 & 0.00 & 0.00 & 0.00 \\
\hline
\end{tabular}




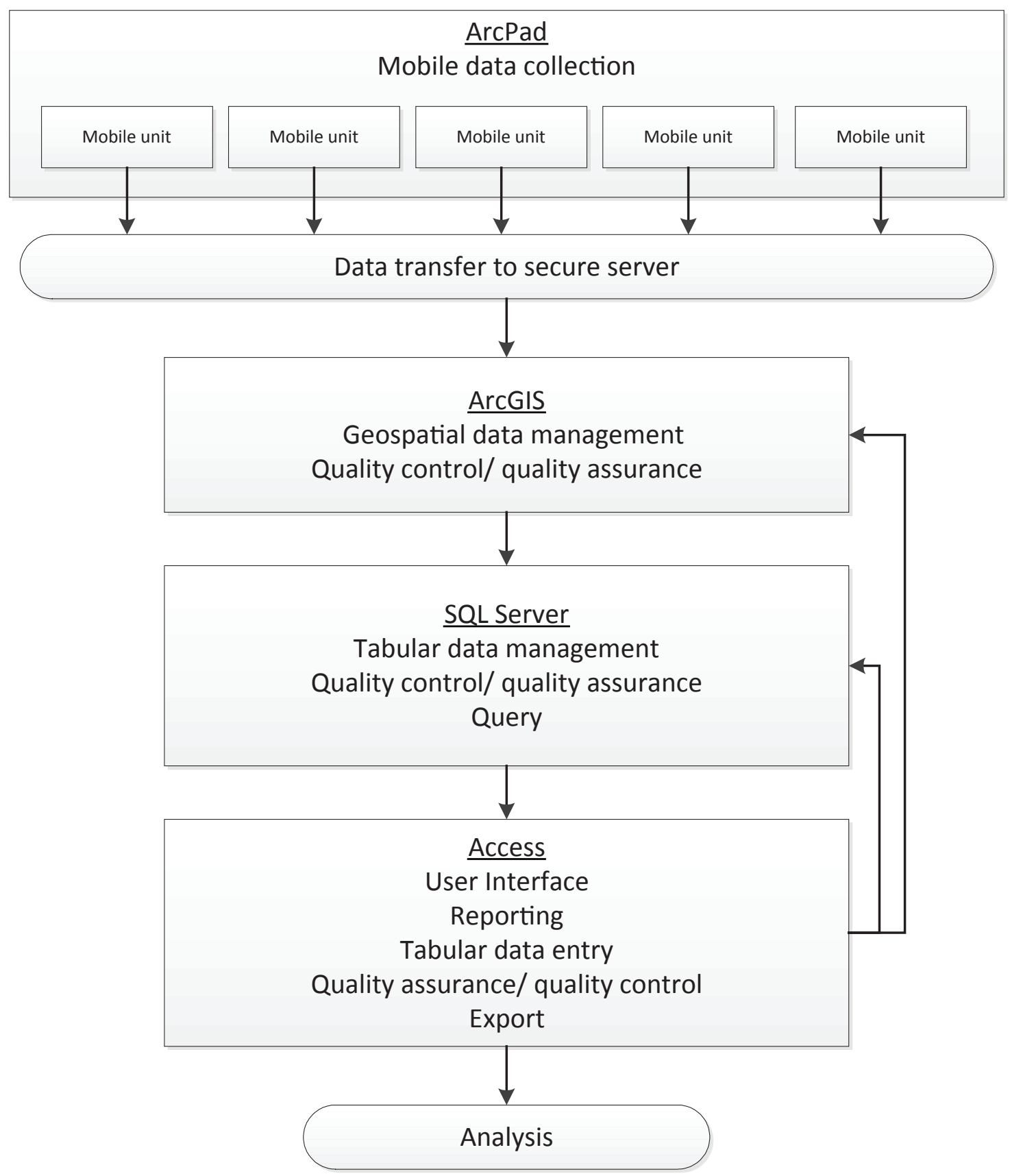

Figure 31. The Sturgeon Information Management System (SIMS) that accommodates and integrates multiple disparate data types by using a suite of software to accommodate various data formats and the demand for near real-time updates. 
fields. Additionally, the application automatically records date, time, and spatial coordinates from the GPS unit.

Data transfer protocols were established to ensure timely delivery of data being simultaneously collected by multiple field crews from two agencies searching more than 810 miles of the Lower Missouri River. To streamline transfer of field data, a batch process was developed and deployed onto field computers to compile all necessary files for search effort and telemetry location data into one compressed .zip file for quick and easy data transfer. The zip files containing both search effort and telemetry observation data were transmitted to a secure server located at USGS at the end of each day. The data from each search effort were then archived. A series of custom tools in an ArcGIS ${ }^{\circledR}$ (ESRI, Redlands, Calif.) map document are used to simplify the check-in process for data files from multiple crews. If any data integrity issues arise during the data check-in process the field crew responsible for the data are contacted immediately. The new sturgeon telemetry observations and search effort data are incorporated into the larger geospatial database each morning and are immediately visible to multiple endusers. The daily files and master database are maintained on local servers, which are scheduled for daily backup.

A relational database has been developed and maintained using SQL Server 2008® (Microsoft Inc., Seattle, Wash.) to manage and maintain large volumes of tabular data. Each table in the database is designed to store a specific and defined set of data. Data tables for sampling efforts, telemetry tag implantations, individual fish metrics, physiology, environmental variables, and others have been integrated so that the data are readily available and searchable. These data commonly originate in disparate physical locations and in very different file formats (for example ESRI shape files, text files, and comma delimited files). Relationships (or linkages between related tables) were developed to seamlessly integrate tabular and geospatial telemetry data. Robust database relationships are critical as they provide a mechanism to combine data from multiple tables into a single view, or virtual table that looks and functions like a table but is maintained dynamically by the database. By creating well defined relationships between many tables in various combinations, the relational data model provides a way to seamlessly extract data from data volumes in near real time to produce meaningful and near real-time information to support rapid decision making.

A functionally-driven SIMS user interface was developed and maintained using Microsoft Access ${ }^{\circledR}$ (Microsoft Inc., Seattle, Washington) to allow users to quickly edit and view data, as well as access near real-time reports that present synthesized information from tabular and geospatial data. Navigation within the SIMS user interface is accomplished through a series of user actions involving clicking on-screen buttons or tabs, selection from drop-down menu options, and entering appropriate search queries in predefined fields, essentially the same navigation features found in most basic software packages or Web sites. The SIMS user interface provided quick access to a wide variety of information in preformatted reports. These reports were developed to present researchers with access to frequently requested information in an easy to read format. The reports rely on the relationships developed and maintained in the relational database to quickly and seamlessly deliver data from numerous data tables or volumes in near real time. This unique interface also allows users to quickly filter and display data graphically, within the SIMS or other commonly used software packages, such as SigmaPlot and ArcMap, to rapidly generate information-rich charts and maps.

\section{Progress and Results}

The SIMS database provides a central and unifying platform to collect, maintain, organize, integrate, and explore the rich and diverse datastream recorded by multiple partners. Data collection and management using the SIMS platform have proved to be reliable, flexible, and capable of reporting information in a near real-time environment. During 2013, the SIMS mobile mapping application was used to record geospatial data detailing all sturgeon telemetry locations and search-effort location data from the CSRP tracking efforts in the Lower Missouri River study area. USGS and NGPC telemetry tracking crews recorded approximately 1,250 pallid sturgeon locations during more than 335 search efforts during 2013. Since 2005, The SIMS mobile mapping application has been used to record more than 4,200 search efforts made by USGS and NGPC researchers, and more than 17,250 telemetry locations for 352 shovelnose sturgeon and 172 pallid sturgeon have been recorded and archived.

The SIMS database compiles more than 11.7 million data records from 45 essential tables to support CSRP research. During 2013, SIMS continued to record and archive tabular data from sampling efforts, telemetry tag implantations, reproductive evaluations, physiological measurements, and genetics tests to maintain records of pallid sturgeon in the CSRP. During 2013, SIMS added 38 records for telemetry tag implantations and reproductive evaluations for 30 pallid sturgeon. Since 2005, 174 pallid sturgeon have been implanted with telemetry tags and DSTs to record temperature and depth (as pressure) at 15 to 30 minute intervals. More than 80 of these pallid sturgeon have been reimplanted with multiple telemetry tags and DSTs during that time. Since 2005, more than 3.3 million depth and temperature records from 117 DSTs have been imported to and archived in the SIMS relational database.

The SIMS database also provided a cumulative archive for large environmental datasets. Since 2005, approximately 6.9 million temperature records have been amassed from a network of 29 CSRP temperature loggers in the Lower Missouri River and its tributaries. The SIMS database also houses 1.6 million temperature and discharge records from a series of 16 USGS streamgage stations in the Missouri River. The SIMS relational database is critical to combining these large, environmental datasets with geospatial telemetry datasets to provide a better understanding of sturgeon movement patterns. 
The SIMS also was used to record data detailing 758 free-embryo sampling gear deployments for spawning verification efforts $(n=64)$ and systematic sampling efforts ( $n=694$ ) during the spring and summer of 2013. The SIMS maintained a digital chain of custody and results tracking for 329 sturgeon free embryos collected during 2013 and remitted for genetic testing at Southern Illinois University Carbondale. Genetic test results from 347 free embryos remitted for species determination during 2012 were obtained from Dr. Heist at Southern Illinois University Carbondale and incorporated into SIMS for analysis and archiving.

\section{Discussion}

The SIMS platform has been developed to streamline data collection, integration, and retrieval, thus preventing users from needing to understand the complex organizational structure of the 45 data tables contained within the relational database. The SIMS platform puts powerful near real-time information in the hands of researchers quickly and easily in more than 20 on-demand reports within the user interface. The SIMS platform allows for rapid compilation and dissemination of information, internally and externally, as information frequently is requested by other programs and agencies to aid in decision making. Data often are requested by the Missouri Department of Transportation, Environmental Design Section before any bridge construction, demolition, or alteration. Information also is shared with USFWS and several state agencies regarding the history for many fish captured during broodstock collection efforts. The SIMS also allows for coordination with the USACE Population Assessment Project database manager to obtain and integrate capture data for any telemetered pallid sturgeon captured by Population Assessment crews.

\section{Task 2. Reproduction, Habitat Use, and Early Life Stage Dynamics of Pallid Sturgeon in the Yellowstone River}

The Upper Missouri River Basin including the thermally and hydrologically impacted Missouri River between Fort Peck Dam and Lake Sakakawea, and the mostly natural Yellowstone River contain a declining adult stock of wild pallid sturgeon. Nearly 1,000 wild adult pallid sturgeon were present in this system during the 1960s, but the wild stock has declined to an estimated 125 adults in recent years (Braaten and others, 2009). Natural recruitment has not occurred presumably for decades as the existing wild population is composed of large (greater than 1,000 mm), old individuals; wild-produced small pallid sturgeon and young age classes are absent indicative of persistent recruitment failure.

Within the Upper Missouri River Basin, the Yellowstone River is a focus area for understanding pallid sturgeon reproductive biology in a natural river system, promoting natural recruitment, and re-establishing viable pallid sturgeon stocks. Within the near-natural hydrologic and thermal regimes characteristic of this system, spawning by wild pallid sturgeon has been documented in the Yellowstone River during 2007 (Fuller and others, 2008) and 2012 (DeLonay and others, 2016).

One of the largest pallid sturgeon restoration efforts in the Missouri River Basin is proposed for the Yellowstone River. Intake Diversion Dam (hereinafter referred to as, Intake Dam), located about 70 river miles upstream from the confluence of the Yellowstone and Missouri Rivers, is a barrier to pallid sturgeon passage. Several adult pallid sturgeon have been documented to migrate upstream to the dam during May and June, fail to pass over the dam, then return to downstream locations (Fuller and others, 2008; DeLonay and others, 2016). Capitalizing on intact natural hydrologic and thermal regimes of the Yellowstone River, proposed enhancement of the reach affected by Intake Dam is targeted to provide pallid sturgeon passage and access to upstream spawning areas. Spawning and successful incubation of embryos in upstream areas of the Yellowstone River will increase the length of free-flowing riverine habitat necessary for drifting free embryos following hatch (Braaten and others, 2008; Braaten and others, 2012b).

Although interrelated and complementary, pallid sturgeon studies under Task 2 are functionally separated into three subtasks to facilitate the presentation of progress and findings in 2013. Those subtasks include (1) migration pathways, habitat use, and reproduction of pallid sturgeon in the Yellowstone River; (2) habitat use and availability during migration, spawning, and drift of pallid sturgeon in the Upper Missouri and Yellowstone Rivers; and (3) data coordination, integration, geospatial analysis, and outreach.

\section{Migration Pathways, Habitat Use, and Reproduction of Pallid Sturgeon in the Yellowstone River, 2013}

Since 2011, the USGS and Montana Fish, Wildlife and Parks (MFWP) have collaborated in the Upper Missouri River Basin to examine the reproductive ecology of pallid sturgeon in altered and natural hydrosystems, and provide critical information needed for restoration efforts in the upper basin. Expanding on earlier assessments of pallid sturgeon reproduction in the Yellowstone River during 2007-10 (Fuller and others, 2008; Fuller and Braaten, 2012), spawning by pallid sturgeon was confirmed in the Missouri River below Fort Peck Dam in 2011 and in the Yellowstone River during 2011 and 2012 (DeLonay and others, 2014; DeLonay and others, 2016). In addition, research efforts yielded the first verifications of successful incubation and hatch of wild-produced embryos in the Upper Missouri River Basin as one genetically confirmed pallid sturgeon free embryo was documented in the Missouri River below Fort Peck Dam in 2011 and one in the Yellowstone River in 2012 (DeLonay and others, 2014; DeLonay and 
others, 2016). Verification of spawning in both river systems has provided an initial understanding of environmental conditions that promote spawning and embryonic survival of pallid sturgeon in altered and natural reaches of the Upper Missouri River Basin. In addition, results from the Upper Missouri River Basin serve as a comparative template to the reproductive ecology of pallid sturgeon in the Lower Missouri River Basin.

A primary focus of work in the Yellowstone River has been directed towards addressing information needs relevant to restoration designs for the reach affected by Intake Dam. As a barrier to upstream passage for pallid sturgeon (U.S. Bureau of Reclamation and U.S. Army Corps of Engineers, 2010), much of the focus for providing passage in this reach of the Yellowstone River has centered on constructing a river-width rock ramp or a bypass channel around the affected reach (U.S. Bureau of Reclamation and U.S. Army Corps of Engineers, 2010, 2012). Recently (2015), construction of a new dam and bypass channel have emerged as the preferred design alternative to facilitate passage (U.S. Bureau of Reclamation and U.S. Army Corps of Engineers, 2012). Work in the Yellowstone River since 2011 has focused on providing pallid sturgeon - specific design criteria to conceptual design considerations. Specifically, studies have assessed pallid sturgeon migration pathways (such as, channel routes used), side channel use/avoidance, swimming capabilities, and depths and velocities negotiated during migrations for various discharge regimes in the Yellowstone River (DeLonay and others, 2014; DeLonay and others, 2016).

Expanding on research and findings from previous years, work in the Yellowstone River during 2013 centered on four objectives: (1) ascertain the temporal periodicity of pallid sturgeon migrations to Intake Dam, (2) identify the location(s) and timing of pallid sturgeon spawning events, (3) characterize and quantify habitat attributes (for example, depth, velocity, substrate) at spawn locations, and (4) verify successful incubation and egg-hatch based on collections of drifting free embryos and larvae.

\section{Methods}

The research population was comprised of 46 wild adult pallid sturgeon including individuals implanted with radio transmitters from previous studies, individuals carrying expired or near-expiring transmitters that were reimplanted, and newly captured individuals that did not previously carry a transmitter. The signal from each transmitter is encoded with a digital identification code (code). New transmitters used at reimplantation have a different code than the expired tags they replace. Sturgeon reimplanted multiple times will have multiple codes through time. Two females were identified as potential candidates for 2013 based on reproductive assessments. Code 40 (a research female that spawned in 2011 as code 117) was caught and reproductively assessed on May 15 (polarity index $[\mathrm{PI}]=0.10$ ). Female code 41 was caught and reproductively assessed on April $25(\mathrm{PI}=0.196)$.
Manual tracking by boat of the Yellowstone River and Missouri River downstream from the Yellowstone River confluence began in April. Pallid sturgeon location points and associated environmental point attributes were recorded on a highly customized mobile mapping and electronic data collection application. Automated ground-based logging stations were deployed in the Yellowstone River (river miles 0.75, 7.0, 16.5, 39.0, 67.0, 72.8) and in the Missouri River (see Task 3) to complement manual tracking and obtain additional information on migrations and movements among river reaches.

Sampling for pallid sturgeon free embryos and larvae began on June 6 and concluded July 10 at sites near river mile 2.4 and river mile 6.3. Samples also were collected for four days immediately downstream of sites where spawning was suspected to have happened (see, "Verification of Pallid Sturgeon Hatch and Drift Entry"). Collection efforts targeting free embryos at suspected spawning sites were timed based upon predicted hatch times at ambient water temperatures and the expectation that free embryos immediately disperse from the spawning site at hatch. The sampling apparatus was comprised of a 3.0-m long tapered rectangular net (1-mm mesh) affixed to a rectangular net-mouth frame $(0.75-\mathrm{m}$ width, 0.5 -m height) supporting two $4.5 \mathrm{~kg}$ sounding weights. Two nets were simultaneously deployed to the riverbed following methods outlined in Braaten and others (2010). Sample contents were transferred to black pans where Acipenseriformes (Scaphirhynchus spp. and paddlefish) eggs, embryos, free embryos and larvae were extracted from the detritus and preserved immediately in 95 percent nondenatured ethanol. In the laboratory, Acipenseriformes free embryos and larvae were tentatively identified as Scaphirhynchus spp., paddlefish or undetermined (including damaged beyond definitive recognition because of smashed bodies and missing parts of bodies) and measured (nearest $0.1 \mathrm{~mm}$ total length). Specimens were submitted for genetic analysis to confirm species identity as paddlefish, shovelnose sturgeon, or pallid sturgeon.

\section{Progress and Results}

\section{Hydrologic Conditions}

Mean discharge in the Yellowstone River during April $\left(5,872 \mathrm{ft}^{3} / \mathrm{s}\right)$, May $\left(15,113 \mathrm{ft}^{3} / \mathrm{s}\right)$, June $\left(27,363 \mathrm{ft}^{3} / \mathrm{s}\right)$, and July $\left(9,757 \mathrm{ft}^{3} / \mathrm{s}\right)$ of 2013 (fig. 32) was 58 percent, 82 percent, 72 percent and 43 percent, respectively, of the long-term means (1911-2012). Discharge was low between April and early May, increased in mid-May to the annual maximum of $52,000 \mathrm{ft}^{3} / \mathrm{s}$ on June 1, declined rapidly in early June, then increased to a secondary period of elevated discharge on June $16-17\left(37,100 \mathrm{ft}^{3} / \mathrm{s}\right)$. Water temperature warmed rapidly during low flows in early May as temperature increased from $10.2^{\circ} \mathrm{C}$ on May 1 to $19.7^{\circ} \mathrm{C}$ on May 16 (fig. 32). Between mid-May and mid-June, alternating periods of decreasing and increasing water temperatures generally followed increasing and decreasing river discharge patterns. After mid-June, in 


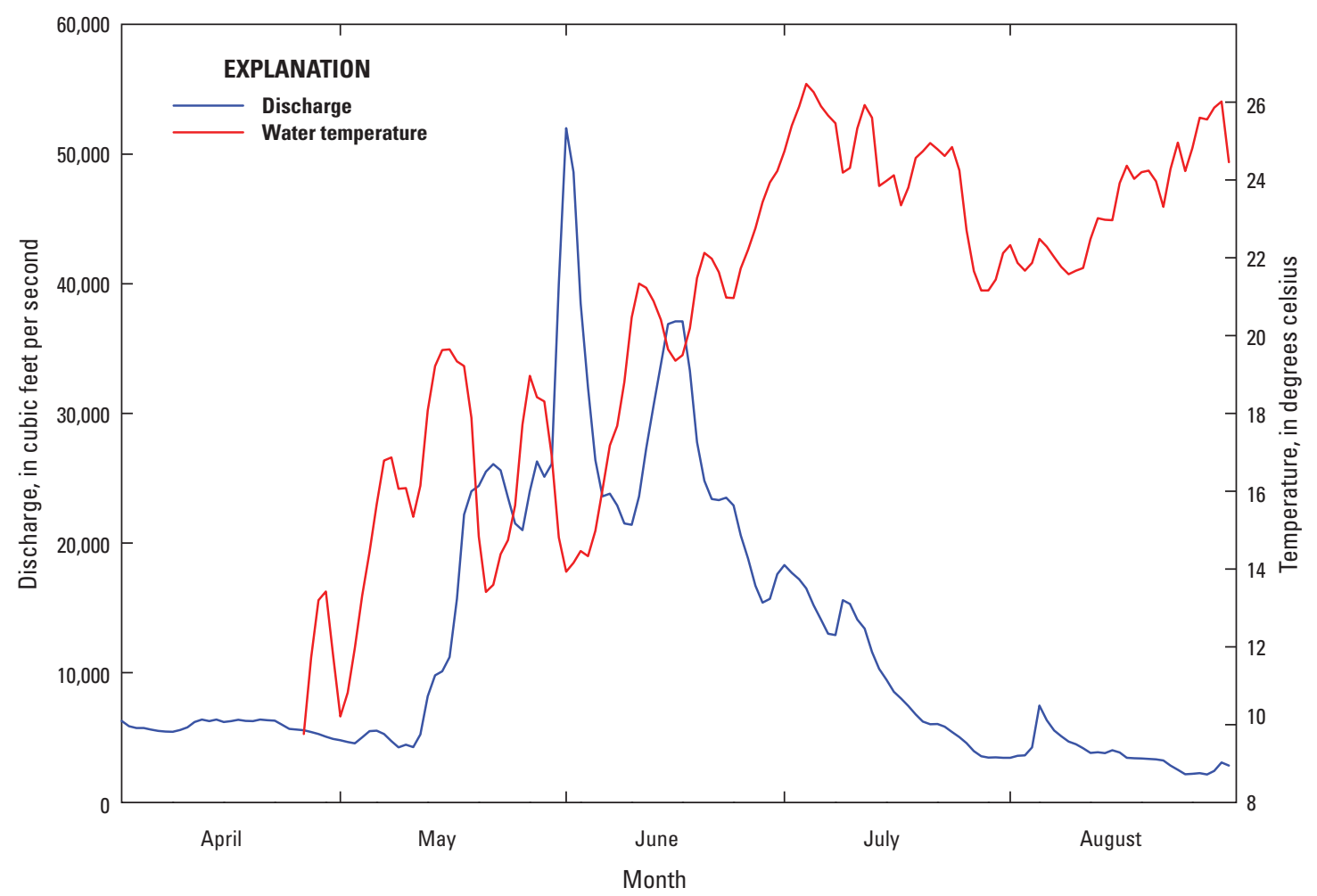

Figure 32. Mean daily discharge (USGS streamgage 06329500 near Sidney, Montana) and water temperature (from water temperature loggers deployed during this study) for the Yellowstone River in 2013.

association with a declining hydrograph, water temperature exhibited a stable increase from $19.3{ }^{\circ} \mathrm{C}$ on June 16 to $26.5^{\circ} \mathrm{C}$ on July 4.

\section{River Use}

Manual locations and detections from telemetry logging stations provided a temporal chronology of pallid sturgeon use patterns of the Yellowstone River. Use of the Yellowstone River by telemetered pallid sturgeon began by early April (fig. 33). Under low flow conditions during April and early May, 33-57 percent of the telemetered population were in the Yellowstone River. Pallid sturgeon use of the Yellowstone River increased after early May as discharge increased, and greater than 90 percent of the telemetered population was present in the system during late May and early June. Use declined during early through mid-June, increased slightly in late June, and then declined through July as pallid sturgeon exited the Yellowstone River.

\section{Migrations to Intake Dam}

Manual tracking complemented with detections from the logging station at Intake Dam identified that seven individual pallid sturgeon (female code 40; male codes 42, 61, 68, 76, 83, 179) migrated to Intake Dam (fig. 34). Code 42 represented the earliest arrival to the dam (May 22) with initial arrivals for other pallid sturgeon ranging from May 23 (codes 61, 179) to June 13 (code 76). Initial migrations to Intake Dam for most individuals generally coincided with periods of elevated flow conditions in the Yellowstone River. Whereas four pallid sturgeon were present for a day or less (from a few minutes to 6 hours), three individuals were present or stayed for multiple days below the dam (fig. 34). Pallid sturgeon passage over Intake Dam was not detected.

\section{Spawning Chronology of Female Pallid Sturgeon Codes 40 and 41}

Before the onset of documented spawning events by female pallid sturgeon codes 40 and 41 (discussed below), large aggregations of males (as many as 15 individuals at a given time) formed and persisted for several days at two locations in the Yellowstone River. Considering the possibility that the male aggregations were precursors to spawn-site selection as has been observed previously in the Yellowstone River, the sites were intensively monitored to detect the presence of female codes 40 and 41 within the male aggregations. One aggregation was documented at river mile 12.5-13.4 during June 7-21, and the second aggregation was at river mile 13.514.2 during June $10-13$. Female code 40 was present within one aggregation on June 7 (water temperature $17.2^{\circ} \mathrm{C}$ ) for a limited duration; however, this female moved downstream and exited the Yellowstone River. Similarly, female code 41 moved downstream past this aggregation and exited the Yellowstone River. Most males at the river mile 12.5-13.4 aggregation site 

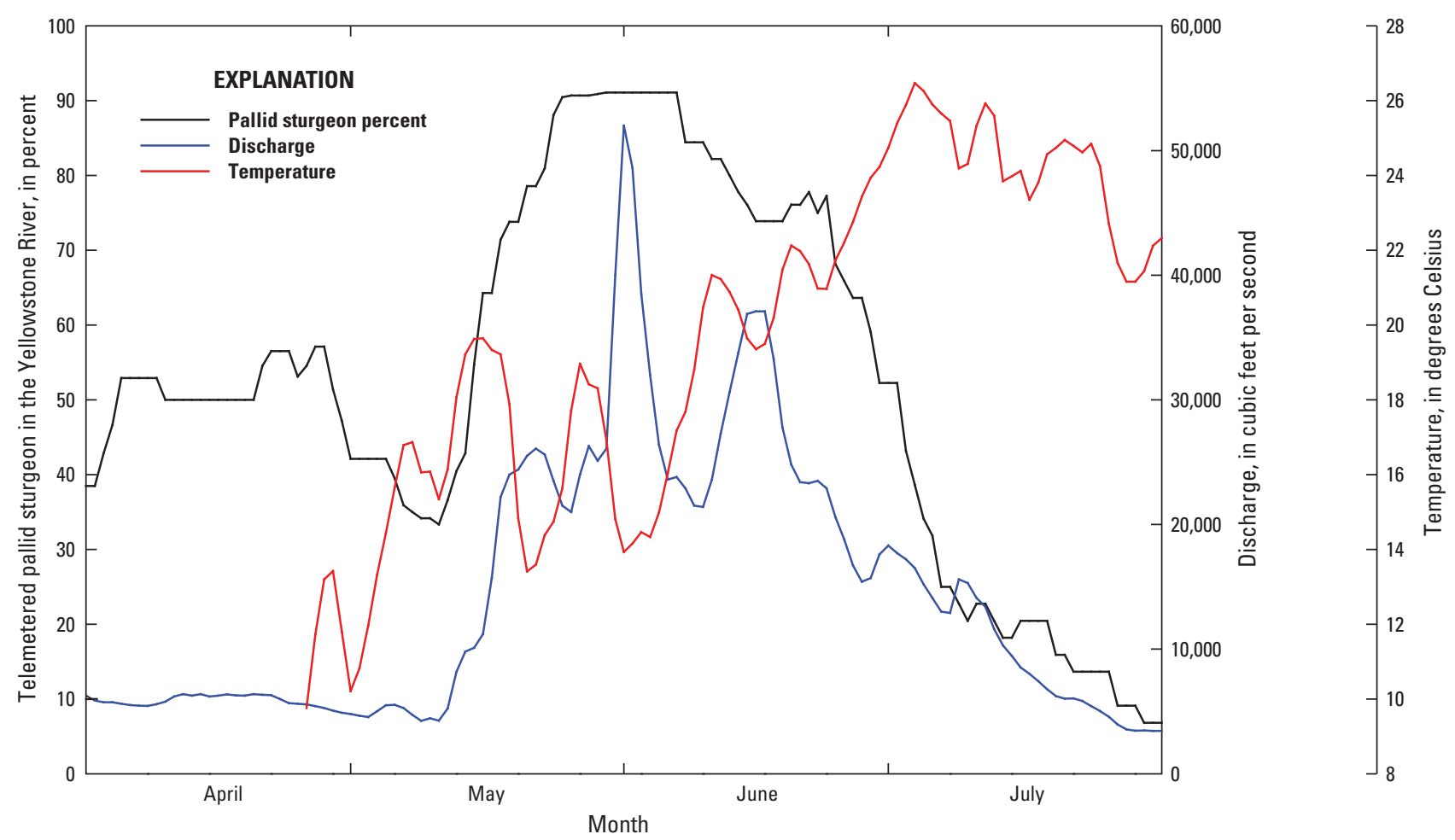

Figure 33. Percent of telemetered pallid sturgeon in the Yellowstone River by date, and corresponding mean daily discharge (USGS streamgage 06329500 near Sidney, Montana) and water temperature (from water temperature loggers deployed during this study) for the Yellowstone River in 2013.

were present during June 14-20 (mean water temperature $=$ $20.4{ }^{\circ} \mathrm{C}$, range $19.4-22.1{ }^{\circ} \mathrm{C}$ ). Anticipating that codes 40 and 41 would return to the male aggregations for spawning, habitat conditions were quantified at the sites as detailed in the following section. After exiting the Yellowstone River, female codes 40 and 41 did not ascend the Yellowstone River to these aggregation sites through the remainder of the spawning season. Rather, known spawning events for codes 40 and 41 were in downstream reaches of the Yellowstone River.

As a spawn candidate for 2013 based on reproductive assessment on April 25, code 41 resided primarily in the Lower Yellowstone River and Missouri River near the Yellowstone River confluence area during late April through early June (fig. 35). In early June, code 41 exited the Yellowstone River and began a pronounced upstream migration in the Missouri River that persisted through June 17 to at least river mile 1,709 (about 127 miles upstream from the Yellowstone River confluence). Capture and reproductive assessment by MFWP crews on June 17 indicated that code 41 remained in spawning condition (body cavity filled with eggs, weight $27.0 \mathrm{~kg}, \mathrm{PI}=0.07)$. Code 41 began downstream movements in the Missouri River between June 17 and June 18, was detected at river mile 1,641 on June 18, and entered the Yellowstone River on June 19. By evening June 19, code 41 was present at river mile 6.7 of the Yellowstone River. On the morning of June 20, code 41 and male code 45 were detected in a reach of the Yellowstone River (river mile 6.8-7.7) identified in previous years as a spawning area. Manual locations and DIDSON imaging indicated code 41 remained in this reach through the day and early evening on June 20 . On June 21, female code 41 and additional male codes 5 and 52 remained in the potential spawning reach. Residency of code 41 and males in this reach of river suggested that spawning activity had occurred or was close to completion. As such, code 41 was targeted for reproductive assessment in the afternoon of June 21. Recapture of code 41 at river mile 7.4 indicated that this female weighed $23.0 \mathrm{~kg}, 4.0 \mathrm{~kg}$ less ( $\sim 15$ percent less) than her gravid weight when assessed on June 17. Likely near completion of the spawning process as evidenced by the loss of body weight, eggs from code 41 were present in the holding tank following capture and could be manually expressed from the vent. Water temperature during the suspected June 20-21 spawning period averaged 22.1 ${ }^{\circ} \mathrm{C}$ and discharge on the descending limb of the hydrograph averaged 24,100 ft $3 / \mathrm{s}$. Habitat conditions in the suspected spawning reach are described in the following section.

In addition to documenting the spawning chronology of code 41 , migration pathways (migration location in the channel, depths and velocities used and available) for two sites were quantified as this female migrated up the Missouri River on June 12 (river mile 1,635.5-1,637.9) and migrated up the Yellowstone River on June 19 (river mile 4.2-5.1). Migration pathway maps are presented in the following section. 

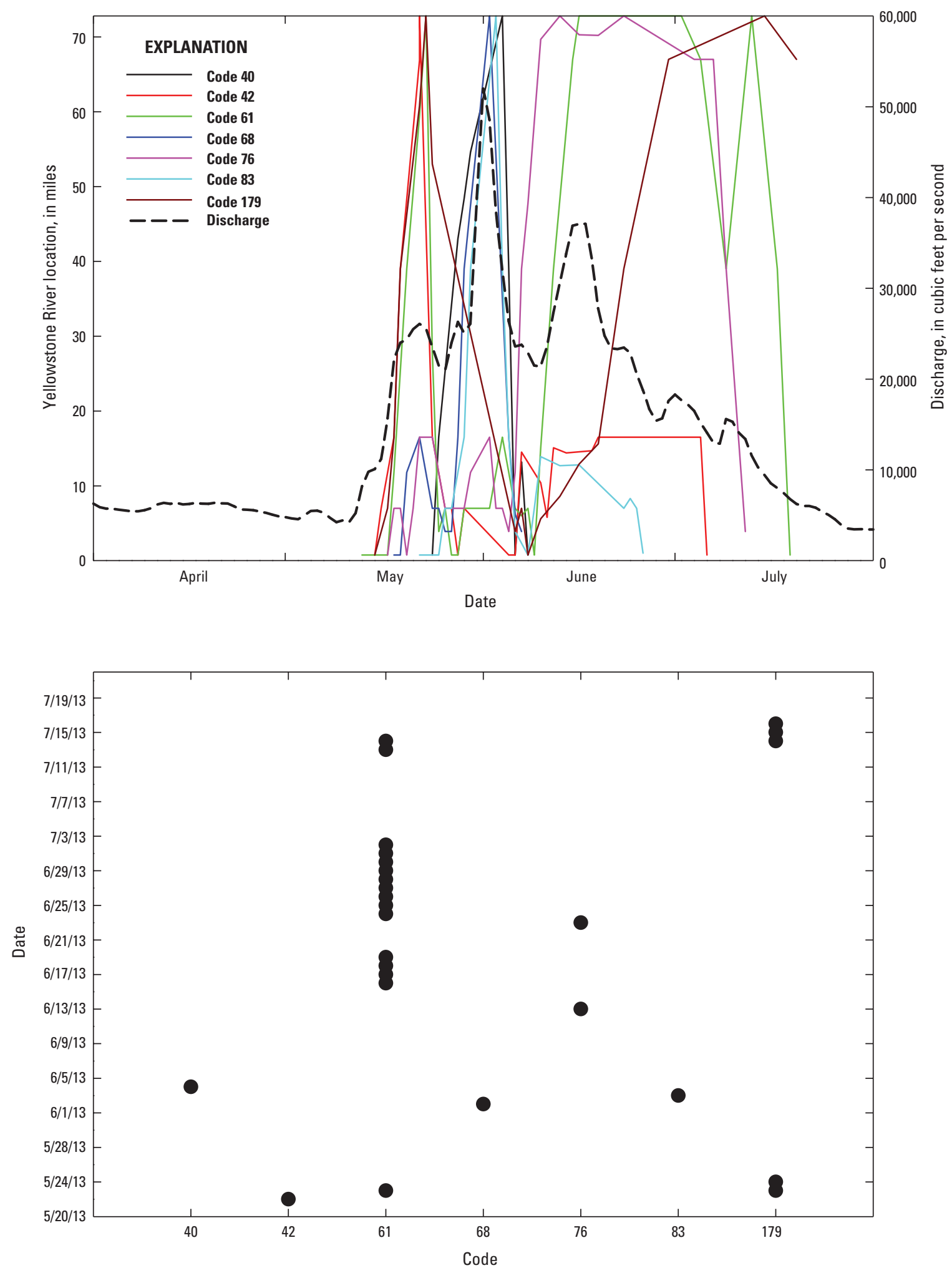

Figure 34. Locations of seven telemetered pallid sturgeon migrating to Intake Diversion (located at river mile 72.8) by date and discharge (USGS streamgage 06329500 near Sidney, Montana; top panel), and dates of residency of pallid sturgeon at Intake Dam (bottom panel) in 2013. 

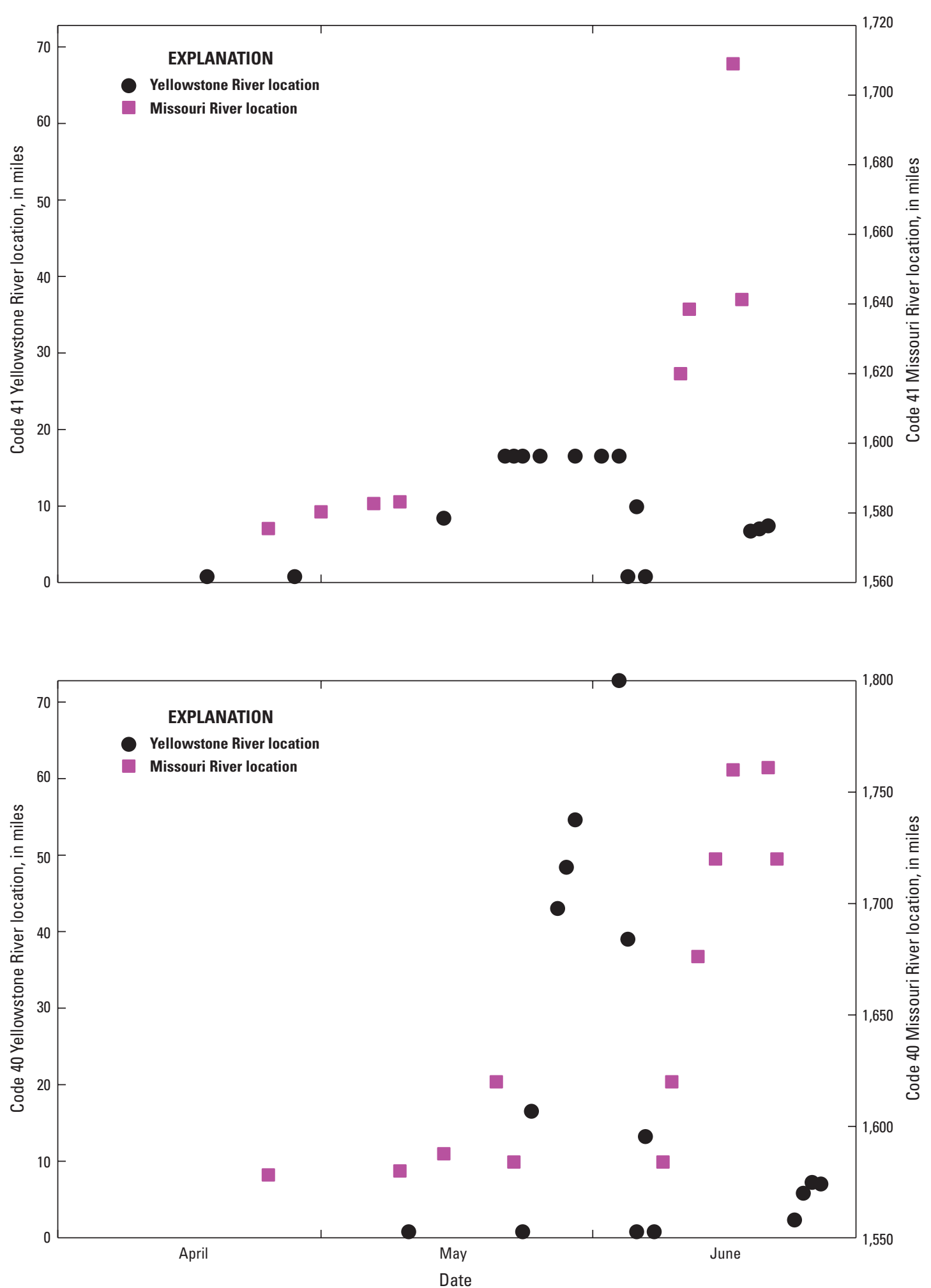

Figure 35. Locations of telemetered female pallid sturgeon code 41 (top panel) and code 40 (bottom panel) in the Yellowstone River and Missouri River during 2013. 
Pallid sturgeon female code 40 also was a spawn candidate in 2013 based on reproductive assessment on May 15. From late April through mid-May, this female alternated use between the Lower Yellowstone River and Missouri River upstream to near Culbertson, Montana (fig. 35). In late May, code 40 exhibited a sequence of rapid long-distance movements that included migration to Intake Dam (arrival June 4), descent from Intake Dam and entry into the Missouri River, and an upstream migration in the Missouri River (beyond river mile 1,760) that included use of the Milk River extending beyond river mile 2.5 during June 18-21. Reproductive assessment by MFWP crews on June 21 indicated code 40 remained in spawning condition (body cavity filled with eggs, weight $=19.5 \mathrm{~kg}, \mathrm{PI}=0.05$ ). On the evening of June 21, code 40 was present below the Milk River in a reach of the Missouri River suspected as a 2011 spawning area. Code 40 exhibited a downstream migration from the Upper Missouri/Milk river area between June 22 and June 24, and re-entered the Yellowstone River on June 24. She was caught and reproductively assessed at river mile 2.4 of the Yellowstone River on June 24 and remained in spawning condition (body cavity filled with eggs, weight $=17.0 \mathrm{~kg}, \mathrm{PI}=0.04$; Note: There was a discrepancy in pre-spawn weight of code 40 between June 21 and June 24 as scale readings indicated that this female weighed $2.5 \mathrm{~kg}$ more when assessed on June 21). Code 40 continued upstream migration in the Yellowstone River after reproductive assessment. On the morning of June 25 and persisting throughout the day, code 40 and multiple males (including, codes $11,46,48,49,50,52,54,63,77,193)$ were aggregated midchannel at river mile 5.7-5.9 suspected to be in the process of spawning. On the morning of June 26, multiple males (for example, codes $11,46,48,49,54,63,77,193)$ remained at the code 40 spawning location; however, code 40 was absent from the aggregation and solitary at river mile 7.2. Suspecting the spawning event was completed; code 40 was captured during the afternoon of June 26 at her isolated location and assessed. Spawning was complete as she weighed $15.0 \mathrm{~kg}, 2.0 \mathrm{~kg}$ less (approximately12 percent less) than her weight on June 24. A few residual eggs were expressed from the vent by pressing on the ventral side of the body. Water temperature during the June 25 spawning event averaged $21.7^{\circ} \mathrm{C}$, and discharge on the descending limb of the hydrograph was $20,600 \mathrm{ft}^{3} / \mathrm{s}$. Habitat attributes characterizing the code 40 spawning location are described in the following section.

\section{Verification of Pallid Sturgeon Hatch and Drift Entry}

Sampling for Acipenseriformes free embryos and larvae to verify successful hatch and drift-entry of pallid sturgeon progeny was done across 19 dates ( 409 samples) between June 6 and July 10 (table 14). The sampling regime yielded 852 specimens, and specimens were tentatively identified as paddlefish, Scaphirhynchus spp. or undetermined (for example, because of mashed bodies, missing body parts).

Targeted sampling for progeny of the code 41 and code 40 spawning events yielded 56.5 percent (481 individuals)
Table 14. Dates and collections of Acipenseriformes early life stages sampled from the Yellowstone River, 2013.

\begin{tabular}{cccc}
\hline $\begin{array}{c}\text { Sample } \\
\text { date }\end{array}$ & $\begin{array}{c}\text { Number of } \\
\text { samples }\end{array}$ & $\begin{array}{c}\text { Number of } \\
\text { Acipenseriformes } \\
\text { free embryos and } \\
\text { larvae }\end{array}$ & $\begin{array}{c}\text { Number of } \\
\text { Acipenseriformes } \\
\text { eggs and embryos }\end{array}$ \\
\hline $6 / 6 / 2013$ & 12 & 1 & 1 \\
$6 / 10 / 2013$ & 12 & 6 & 2 \\
$6 / 11 / 2013$ & 30 & 116 & 4 \\
$6 / 12 / 2013$ & 20 & 69 & 7 \\
$6 / 13 / 2013$ & 16 & 105 & 11 \\
$6 / 14 / 2013$ & 8 & 19 & 3 \\
$6 / 17 / 2013$ & 9 & 6 & 7 \\
$6 / 19 / 2013$ & 8 & 13 & 3 \\
$6 / 20 / 2013$ & 22 & 35 & 3 \\
$6 / 21 / 2013$ & 14 & 0 & 0 \\
$6 / 23 / 2013$ & 34 & 73 & 7 \\
$6 / 24 / 2013$ & 34 & 130 & 7 \\
$6 / 25 / 2013$ & 44 & 57 & 8 \\
$6 / 26 / 2013$ & 40 & 51 & 13 \\
$6 / 29 / 2013$ & 40 & 40 & 2 \\
$6 / 30 / 2013$ & 32 & 101 & 0 \\
$7 / 1 / 2013$ & 12 & 29 & 3 \\
$7 / 9 / 2013$ & 16 & 1 & 0 \\
$7 / 10 / 2013$ & 6 & & 0 \\
\hline
\end{tabular}

of the total free embryos and larvae collected during 2013. Based on initial identifications, 135 Scaphirhynchus spp. free embryos and larvae were sampled during June 23-26 when progeny from code 41 were targeted. Sampling during June 29-July 1 for progeny of the code 40 spawning event yielded 143 individuals tentatively identified as Scaphirhynchus spp.

Genetic testing confirmed four free embryos as pallid sturgeon (Dr. Edward Heist, Southern Illinois University Carbondale, written commun., 2014). Additional genetic testing identified parentage for the four specimens. One pallid sturgeon free embryo collected on June 29 was progeny from telemetered female code 40 and telemetered male code 48 that were part of a June 25 spawning aggregation at river mile 5.7-5.9 of the Yellowstone River. Two pallid sturgeon free embryos sampled on June 25 were progeny of a single known (for example, previously handled, genetically archived) male and female; however, neither parent carried a transmitter so the exact spawn and hatch-source location could not be determined. The fourth pallid sturgeon free embryo was collected on June 26, and also was progeny of a known male and female. Similar to above, neither the parental male nor female carried a transmitter so the exact spawn and hatch-source location could not be determined for this free embryo. 


\section{Discussion}

Research activities during 2013 continued to provide additional information relevant towards restoration efforts in the Yellowstone River and refine the knowledge base of pallid sturgeon reproductive ecology in the Upper Missouri River Basin. As a focal point for restoration, construction of a bypass channel through the reach affected by Intake Dam on the Yellowstone River (U.S. Bureau of Reclamation and U.S. Army Corps of Engineers, 2012) is projected to facilitate access to upstream spawning areas for migrating pallid sturgeon. Work in 2013 identified that 15 percent of the telemetered pallid sturgeon population migrated to Intake Dam primarily during late May through mid-June. Comparatively, 26 percent and 12 percent of the telemetered population migrated to Intake Dam in 2011 and 2012, respectively, with the earliest arrivals in early May (DeLonay and others, 2014; DeLonay and others, 2016). Collective results from these studies suggest that passage options considered for the Intake reach should be designed to facilitate passage under a range of flow conditions typical during early-May through mid-June as this timeframe is when most pallid sturgeon arrive at the dam.

Documented accounts of pallid sturgeon reproduction in 2013, complemented with earlier investigations in the Upper Missouri River Basin, have markedly enhanced science centered on defining the spatial and temporal dynamics of pallid sturgeon reproduction. Research during the mid-1990s provided initial inferences on spawning of pallid sturgeon as aggregations in the lower 8 miles of the Yellowstone River during late spring and early summer established the hypothesis that spawning may take place in the lower reaches of the Yellowstone River (Bramblett and White, 2001). Investigations during 2007 provided the first conclusive evidence that pallid sturgeon spawned in the Yellowstone River, and although the specific timing and location of spawning was not known, it was suspected that spawning was near river mile 7.5 during June 13 to June 16 based on an aggregation of males and the spawn candidate females (Fuller and others, 2008). Expanding on this work, studies in the Yellowstone River during 2012 isolated the location (river mile 6.7-7.1) and date (June 19) of a spawning event involving female code 30. In 2013, spawning by code 41 was in a similar reach of river (river mile 6.7-7.7) and similar dates (June 20-21) as code 30 in 2012. For code 40 in 2013, spawning was slightly downstream (river mile 5.7-5.9) and slightly later (June 25) than documented for other pallid sturgeon in the Yellowstone River. Replicated accounts of reproduction during different years establish the importance of the Lower Yellowstone River as a spawning area for pallid sturgeon; however, additional spawning locations may exist in upstream areas as suggested by Fuller and others (2008). Moreover, replicated accounts of reproduction for different years are contributing to an improved understanding of environmental conditions (for example, flow and temperature regimes) for which pallid sturgeon reproduction occurs, and defining annual consistency (or variability) of habitat conditions at spawning locations.

Pallid sturgeon in the Yellowstone River-Missouri River hydrosystem have experienced a lack of recruitment presumably for several decades as the extant wild stock is composed of large adults (U.S. Fish and Wildlife Service, 2007; Braaten and others, 2009) and wild-produced small individuals have not been detected during decades of netting efforts. Verification of pallid sturgeon spawning in the Yellowstone River and Missouri River below Fort Peck Dam (during extreme flow conditions of 2011) indicates that conditions suitable for reproduction can occur and suggests that the lack of wild recruitment is not restricted exclusively to the lack of reproduction. Whereas reproduction can occur, limited information on success of the spawning event(s) including total reproductive output, hatch success and drift-entry of free embryos has been available to isolate factors operating during this time period as potential contributors of recruitment failure. Verification of hatch success from the Missouri River below Fort Peck Dam in 2011 and Yellowstone River in 2012 based on collections of a single free embryo pallid sturgeon in each river system (DeLonay and others, 2014; DeLonay and others, 2016) indicates that environmental conditions suitable for incubation, hatch and drift-entry can occur. With collection of drifting free embryo pallid sturgeon in 2013, replication of incubation success and entry of free embryos into the drift have been demonstrated in the Yellowstone River. Intensive sampling for drifting free embryos and larvae in the Yellowstone River below the code 40 and 41 spawning locations yielded four pallid sturgeon free embryos and hundreds of shovelnose and paddlefish. Identification of pallid sturgeon from telemetered and non-telemetered adults provides additional information on spawning habitat, reproductive output, incubation success, and drift entry of pallid sturgeon free embryos for conditions different than those conditions in 2011 (Missouri River) or 2012 (Yellowstone River).

The mismatch (Kynard and others, 2007) between the length of free-flowing riverine habitat required by drifting free embryos and length of riverine habitat available to early drifting life stages below spawn and hatch locations stages (Kynard and others, 2007; Braaten and others, 2008; Braaten and others, 2012b) has been proposed as a possible mechanism for lack of recruitment in the Missouri River-Yellowstone River hydrosystem. Expanding on this hypothesis, work in 2013 investigated potential dispersion and retention through reaches of the Missouri River and Yellowstone River. Continued analyses of this dataset will yield additional insights into the drift dynamics of pallid sturgeon free embryos and larvae to illustrate potential retention and survival of early life stages in the free-flowing reaches. 


\section{Determine Habitat Use and Availability during Migration, Spawning, and Drift of Pallid Sturgeon in the Upper Missouri and Yellowstone Rivers}

Physical habitat evaluations in the Lower Missouri River described in Task 1 were complemented with an equivalent objective in the Upper Missouri and Yellowstone Rivers. The Upper Missouri and Yellowstone Rivers present an opportunity to add additional dimensions to understanding of habitat selection during migration, spawning, and drift. Channel morphology in the Upper Missouri River is minimally altered between Fort Peck Dam and the headwaters of Lake Sakakawea. The Yellowstone River has a natural channel morphology, with the exception of a longitudinal barrier at Intake, Montana. Natural channel morphology is rare on the Lower Missouri River, where our previous habitat assessments have taken place. Additionally, although the flow regime of the Upper Missouri River is highly regulated, flow regime in the Yellowstone River is nearly unaltered. Thus, the 73-mile reach of the Lower Yellowstone River between Intake Dam and the confluence with the Upper Missouri River is arguably the best remaining natural reference condition for the combination of channel morphology and flow regime in the Missouri River Basin. Moreover, pallid sturgeon spawning has been documented in this reach, making it an important reference condition. In 2011 and 2012, coordination of physical habitat evaluation and telemetry efforts resulted in measurement of multiple migration pathways and documentation of one highprobability spawning site in the Yellowstone River.

Work in the Yellowstone River during 2013 centered on four objectives: (1) characterize habitat at spawning and hatching sites, (2) characterize migration pathways, as needed, (3) evaluate strategies for measurement of dispersion coefficients in the shallow flow conditions present in the Upper Missouri and Yellowstone Rivers, and (4) evaluate spatial patterns in dispersion characteristics within these two rivers.

\section{Methods}

\section{Habitat and Habitat Dynamics at Spawning and Hatching Sites}

As in previous years, spawning sites were identified through tracking of reproductive females. We applied protocols for mapping physical habitat that were developed in the Lower Missouri River. Because depths are generally much lower in the Yellowstone and Upper Missouri Rivers than in the Lower Missouri River, it was not possible to map bathymetry using a multibeam echosounder. Instead, we used the protocol developed in the Lower Missouri River for simultaneously mapping depths and velocities at spawning sites with an ADCP (DeLonay and others, 2009; Reuter and others, 2009). The ADCP was integrated with a differential GPS to provide accurate positioning. Mapping at spawning locations extended over adjacent areas to allow characterization of all habitats available during spawning, as well as the patch directly used by the sturgeon. Hydroacoustic data were processed and used to create maps of depth and velocity, and to extract quantitative data for statistical analyses (Elliott and others, 2004; Jacobson and others, 2004a; Gaeuman and Jacobson, 2005, 2006). Our mapping protocols supplement previous years' data, providing habitat information around sturgeon locations at a spatial resolution appropriate to the fish. This mapping effort serves to quantify spawning habitats sought out by sturgeon and characterizes the environments where larval drift begins. We also mapped locations where male aggregations were documented on the Yellowstone River during the migratory and reproductive period.

We characterized the substrate grain size distribution on the surface of the bed at one spawning location near Fairview, Montana that was used by pallid sturgeon code 30 in 2012 and by code 41 in 2013. Collection of this data served two purposes: (1) it provided a quantitative description of substrate grain size at a known spawning location; and (2) it allowed us to evaluate sediment sampling techniques. At the sampling location, we collected pipe dredge samples at regular intervals on a 105 by $500 \mathrm{~m}$ grid. The proportion of sand (sediment greater than $2 \mathrm{~mm}$ ) present in each sample was visually estimated in the field and gravel was returned to the laboratory for sieving.

\section{Analysis of Drift Potential}

In addition to hydroacoustic mapping of spawning sites, we collected ADCP data on the Yellowstone and Upper Missouri Rivers to estimate longitudinal dispersion coefficients for these two segments of river. Because this was our first attempt to measure and calculate dispersion coefficients on the Yellowstone and Upper Missouri River, this analysis was exploratory in nature and a primary focus was evaluating the feasibility of calculating dispersion coefficients from ADCP data collected in shallow and multithreaded sections of river. We evaluated the sensitivity of calculated dispersion coefficients to factors such as boat speed, survey extent, calibration of magnetic variation for the ADCP, and variability in local channel topography at multiple scales. At each measurement cross-section, four reciprocal transects were surveyed. We calculated dispersion coefficients for each cross-section using AdcpXP, a software package developed for post-processing ADCP data (Kim, 2012; Kim and Muste, 2012).

\section{Progress and Results}

\section{Habitat and Habitat Dynamics at Spawning and Hatching Sites}

In 2013, we documented river bathymetry and velocities at one spawning reach in the Yellowstone River and 
one suspected spawning reach in the Upper Missouri River (table 15). On the Yellowstone River, a reach including a spawning patch documented in 2012 for pallid sturgeon code 30 on June 19, 2012, and June 20, 2012, was mapped on June 7-8, 2013 (fig. 36). This site was not mapped in 2012 because it was not possible to survey this site at the same discharge as when the spawning occurred until 2013. Two pallid sturgeon also were documented spawning in this reach in 2013: code 41 spawned in a patch near river mile 6.8 on June 20, 2013, and code 40 spawned in a patch near river mile 5.8 on June 25 and 26, 2013. On the Upper Missouri River, we mapped a site near river mile $1,759.5$ at a location where pallid sturgeon may have spawned in 2011 (fig. 37). The number of spawning sites mapped was limited by the number of sites documented by telemetry crews.

In addition, we documented the locations where male pallid sturgeon were aggregating during the May-June reproductive season on the Yellowstone River. Previous tracking (Bramblett and White, 2001; Fuller and others, 2008; DeLonay and others, 2016) suggests that male sturgeon aggregate at or near spawning locations during the spring on the Yellowstone River. We mapped aggregation sites at two different locations. The first aggregation site, located near river mile 13.9 on the Yellowstone River, was mapped on June 13, 2013 (fig. 38). The second site, located near river mile 12.9 on the Yellowstone River, was mapped at two different discharges. On June 17, 2013, the discharge was approximately 36,200 $\mathrm{ft}^{3} / \mathrm{s}$ and on June 21,2013 , the discharge was approximately $22,400 \mathrm{ft}^{3} / \mathrm{s}$ (figs. 39 and 40). The upstream reach had loose aggregations of 16 different individuals present at some point from June 7, 2013 through June 19, 2013. The downstream reach had 19 different individual pallid sturgeon present for some time period from June 7, 2013, through June 21, 2013.
These aggregations also were documented by field crews using the DIDSON acoustic camera and sidescan sonar.

In addition to spawning and aggregation sites, in 2013 we had the opportunity to map two migration pathways. On June 14 and June 15, 2013, a migration pathway was mapped on the Missouri River from approximately river mile 1,636.6-1,637.9 (figs. 41 and 42). Reproductive female pallid sturgeon code 41 migrated up the Missouri River in a $3.8 \mathrm{~km}$ pathway documented June 12, 2013, from 11:52 AM to 3:09 PM through two channel cross overs and generally selecting a lower-velocity pathway. After running up the Missouri River, code 41 was mapped again migrating up the Yellowstone River on June 19, 2013, approaching the spawning patch at river mile 6.8 near Fairview, Montana. This migration pathway was mapped on June 20, 2013, extending from approximately river mile 4.1-5.1 and shows movement through the main channel of the Yellowstone River along the right descending bank through a wide range of velocities (fig. 43).

A single free-embryo and larval sampling site was mapped, located on the Yellowstone River from approximately river mile 2.2-2.6 (fig. 44). Sampling at this site was described earlier (see, "Migration Pathways, Habitat Use, and Reproduction of Pallid Sturgeon in the Yellowstone River, 2013").

Substrate was sampled at the spawning patch where code 30 spawned in 2012 and code 41 spawned in 2013 near Yellowstone River mile 6.5 on June 18, 2013. Qualitative observations of side-scan imagery indicated the presence of gravel on the bed at this spawning location. Of the 44 pipe dredge samples collected at this location, 36 percent of the samples were composed entirely of sand and 77 percent of the samples were composed of at least 90 percent sand. Of those samples that contained a significant fraction of gravel (greater than 10 percent of the sample greater than $2 \mathrm{~mm}$ ), most of

Table 15. Summary data for habitat assessment efforts in 2013.

[Habitat surveyed denotes habitat type. Mont., Montana; ADCP, acoustic Doppler current profiler; NA, not applicable]

\begin{tabular}{|c|c|c|c|c|c|c|c|}
\hline $\begin{array}{l}\text { Habitat } \\
\text { surveyed }\end{array}$ & Code(s) & $\begin{array}{c}\text { Date } \\
\text { (month/day/ } \\
\text { year) }\end{array}$ & River & $\begin{array}{c}\text { River mile } \\
\text { location }\end{array}$ & $\begin{array}{c}\text { Nearest } \\
\text { streamgage }\end{array}$ & $\begin{array}{c}\text { Discharge, } \\
\text { in cubic feet } \\
\text { per second } \\
\left(\mathrm{ft}^{3} / \mathrm{s}\right)\end{array}$ & $\begin{array}{c}\text { Survey } \\
\text { type }\end{array}$ \\
\hline Spawning & $30,40,41$ & $6 / 7 / 2013$ & Yellowstone River & $5.8-7.5$ & Sidney, Mont. & 22,800 & $\mathrm{ADCP}$ \\
\hline Spawning & $30,40,41$ & $6 / 8 / 2013$ & Yellowstone River & $5.8-7.5$ & Sidney, Mont. & 21,900 & $\mathrm{ADCP}$ \\
\hline Male aggregation & Multiple & $6 / 13 / 2013$ & Yellowstone River & $13.5-14.1$ & Sidney, Mont. & 29,600 & $\mathrm{ADCP}$ \\
\hline Migration & 41 & $6 / 14 / 2013$ & Missouri River & $1636.6-1637.9$ & Culbertson, Mont. & 32,900 & $\mathrm{ADCP}$ \\
\hline Migration & 41 & $6 / 15 / 2013$ & Missouri River & $1635.4-1635.9$ & Culbertson, Mont. & 36,000 & $\mathrm{ADCP}$ \\
\hline Spawning & NA & $6 / 16 / 2013$ & Missouri River & $1759.0-1760.0$ & Wolf Point, Mont. & 17,400 & $\mathrm{ADCP}$ \\
\hline Male aggregation & Multiple & $6 / 17 / 2013$ & Yellowstone River & $12.5-13.3$ & Sidney, Mont. & 36,200 & $\mathrm{ADCP}$ \\
\hline Larval & NA & $6 / 18 / 2013$ & Yellowstone River & $2.2-2.6$ & Sidney, Mont. & 32,300 & $\mathrm{ADCP}$ \\
\hline Free embryo and larval & 41 & $6 / 20 / 2013$ & Yellowstone River & $4.1-5.1$ & Sidney, Mont. & 23,900 & $\mathrm{ADCP}$ \\
\hline Male aggregation & Multiple & $6 / 21 / 2013$ & Yellowstone River & $12.4-13.3$ & Sidney, Mont. & 22,400 & $\mathrm{ADCP}$ \\
\hline
\end{tabular}




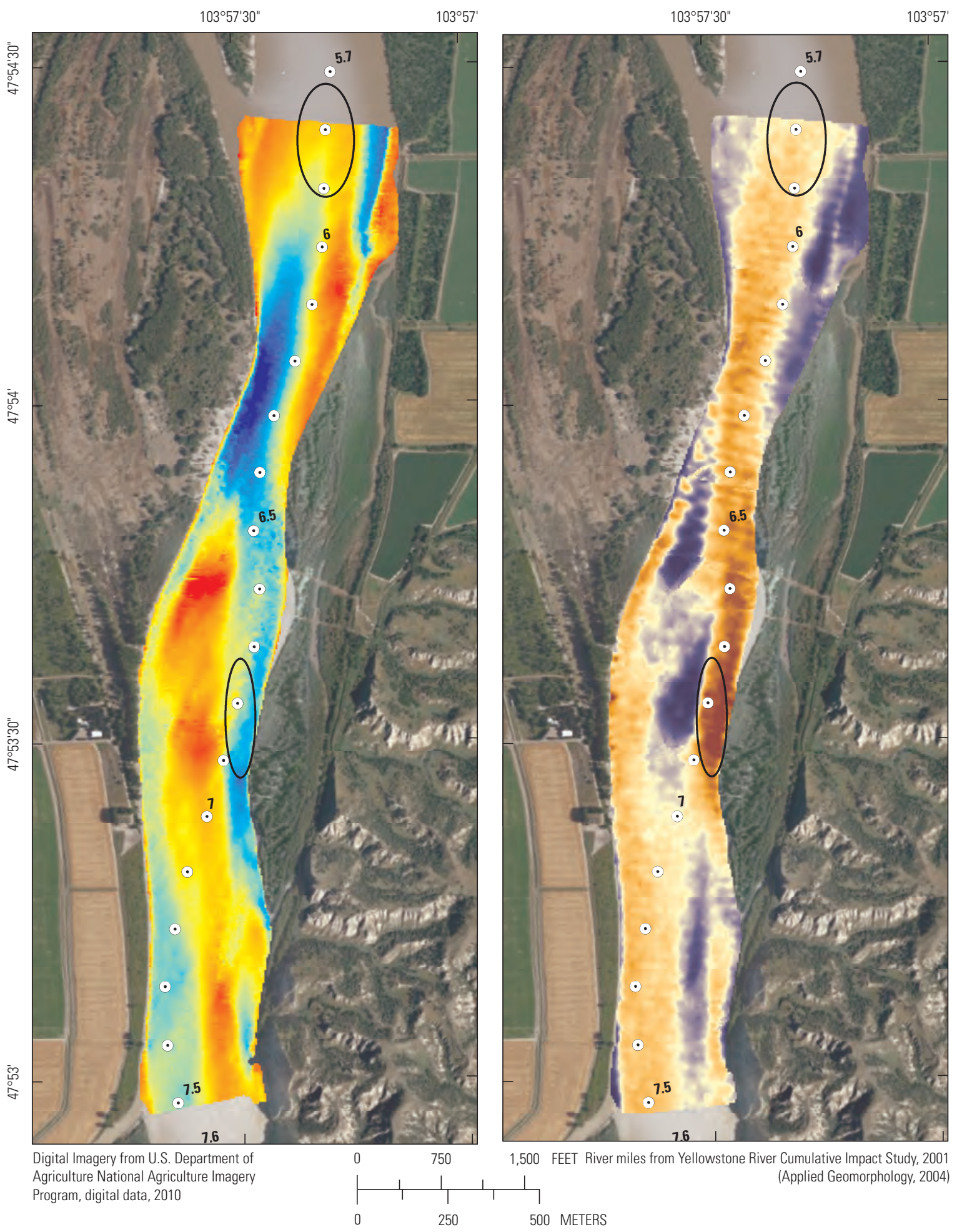

EXPLANATION

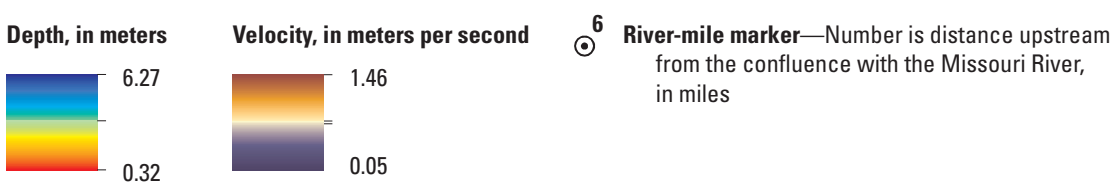

Figure 36. Bathymetric and acoustic Doppler current profiler maps showing site where pallid sturgeon spawning was documented in 2013. Black ovals indicate the approximate locations where sturgeon spawned. 

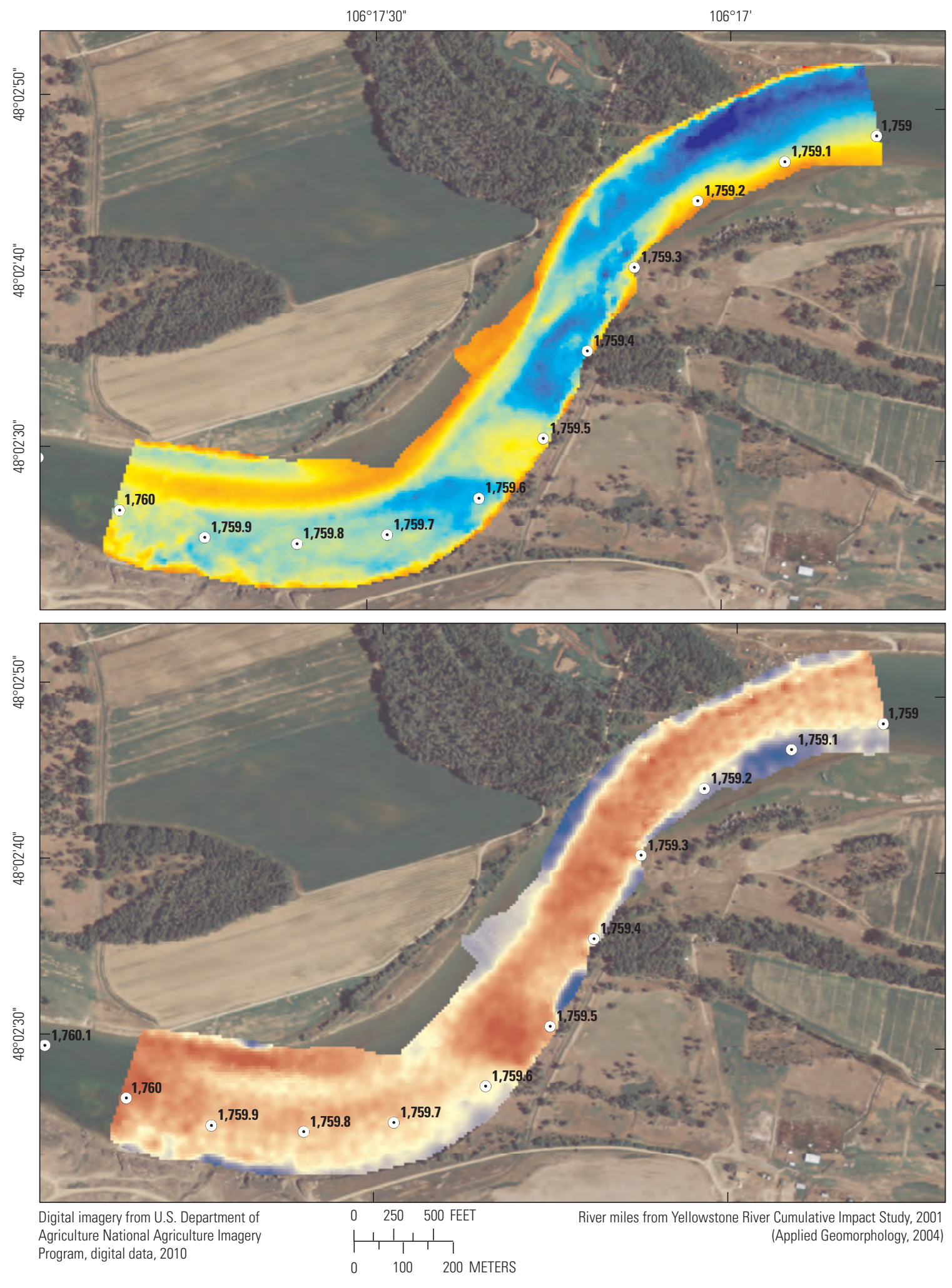

EXPLANATION

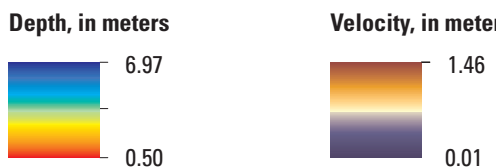

1,760 River mile marker-Number is distance upstream from the confluence with the Mississippi River, in miles

Figure 37. Bathymetric and acoustic Doppler current profiler maps showing site where pallid sturgeon are suspected to have spawned in 2011. 

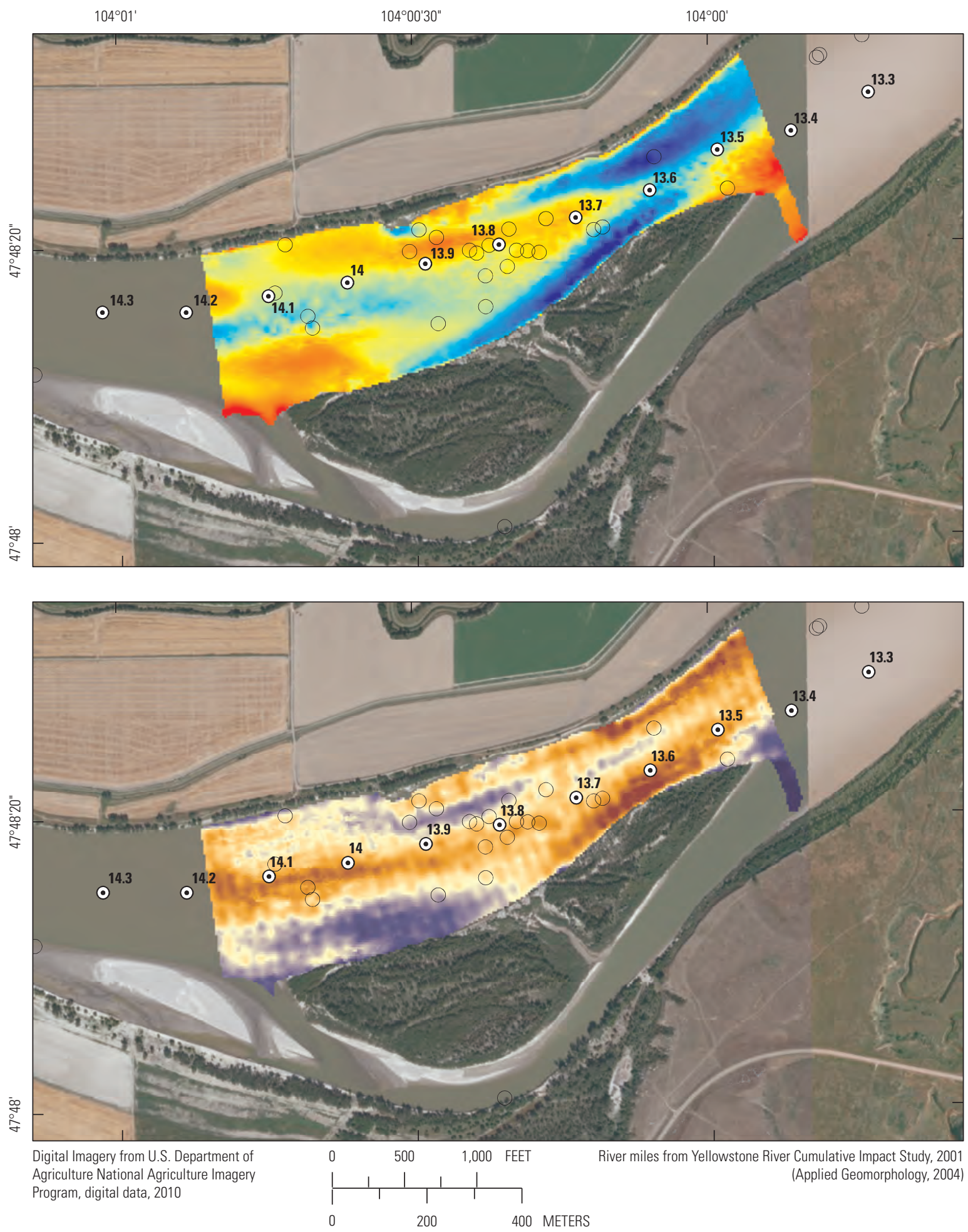

\section{EXPLANATION}

Depth, in meters

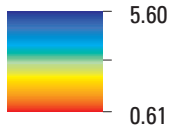

Velocity, in meters per second

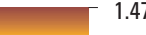

1.47

0.30 $\odot^{14}$ River-mile marker-Number is distance upstream from the confluence with the Missouri River, in miles
Sturgeon locations - Telemetry points representing fish locations from June 10 through June 13, 2013

Figure 38. Bathymetric and acoustic Doppler current profiler maps showing site where male pallid sturgeon aggregation was documented from June 10, 2013, to June 13, 2013. 


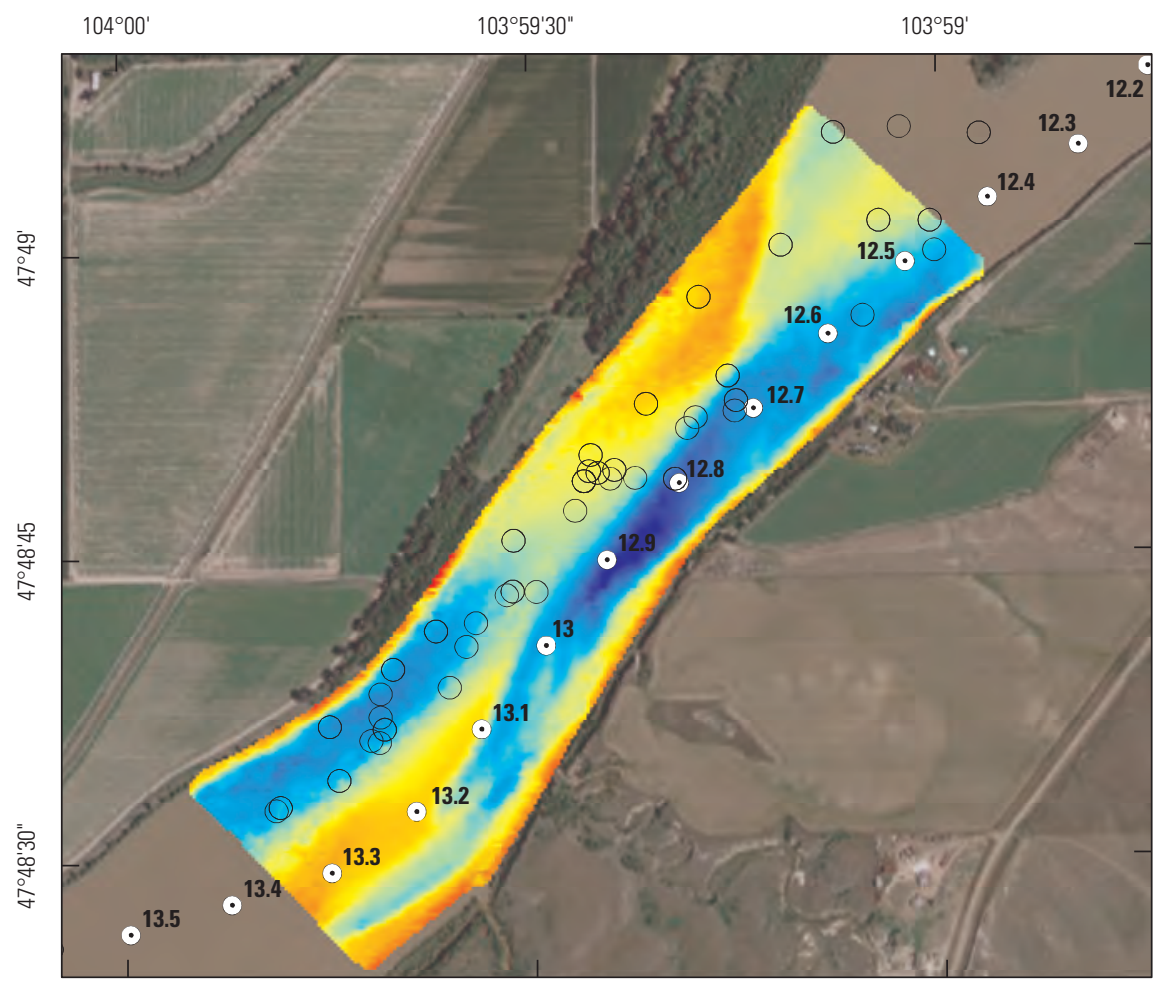

\section{EXPLANATION}

Depth, in meters

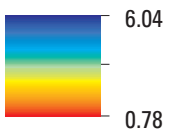

Velocity, in meters per second

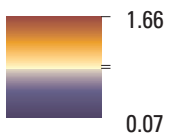

$\odot^{13}$ River-mile marker-Number is distance upstream from the confluence with the Missouri River, in miles

Sturgeon locations - Telemetry points representing fish locations from over 20 individual pallid sturgeon from June 7 through June 21, 2013

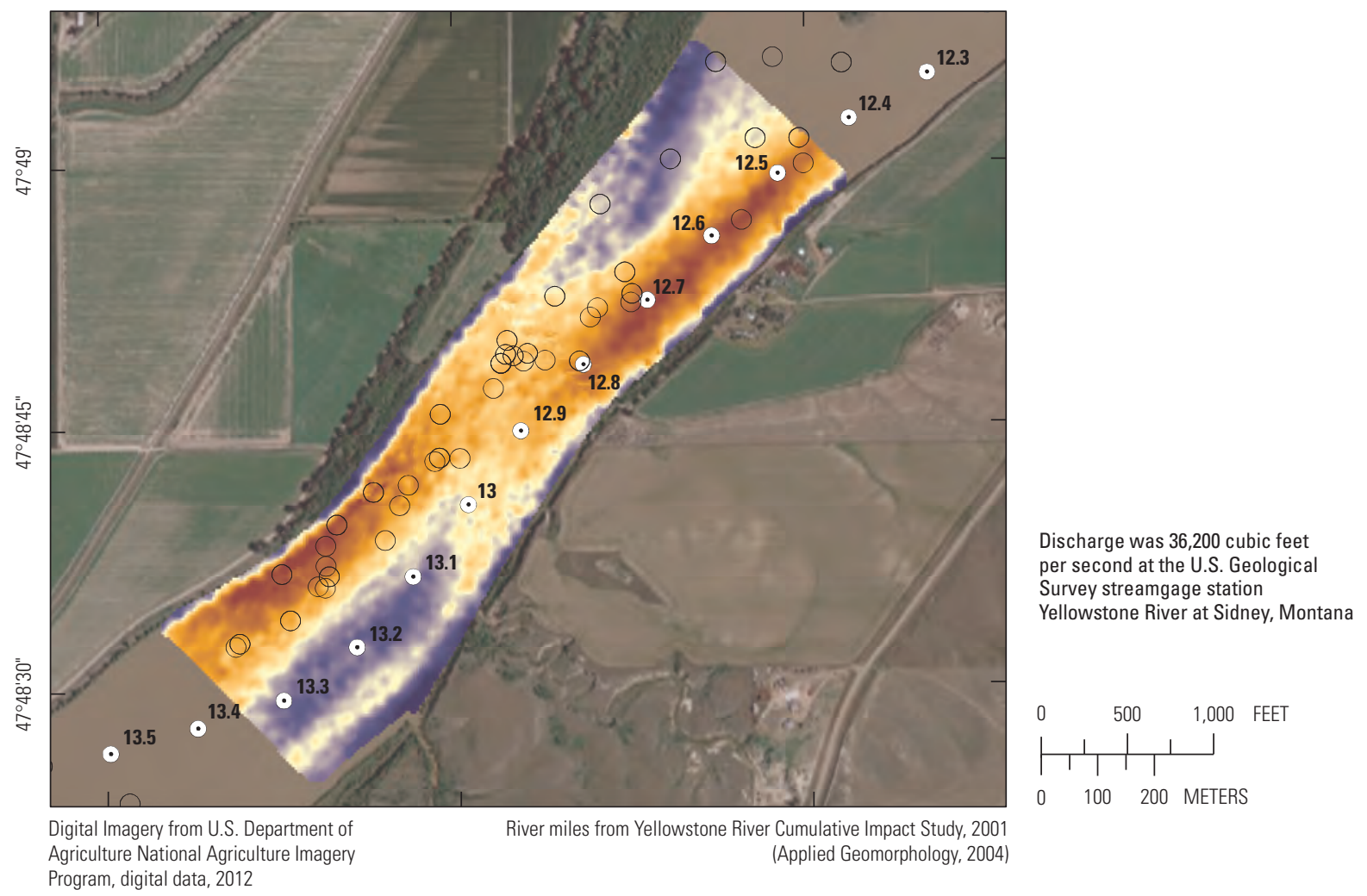

Figure 39. Bathymetric and acoustic Doppler current profiler maps showing site where male pallid sturgeon aggregation was documented from June 7, 2013, to June 21, 2013. Discharge was approximately 36,200 cubic feet per second when mapped on June 13, 2013. 


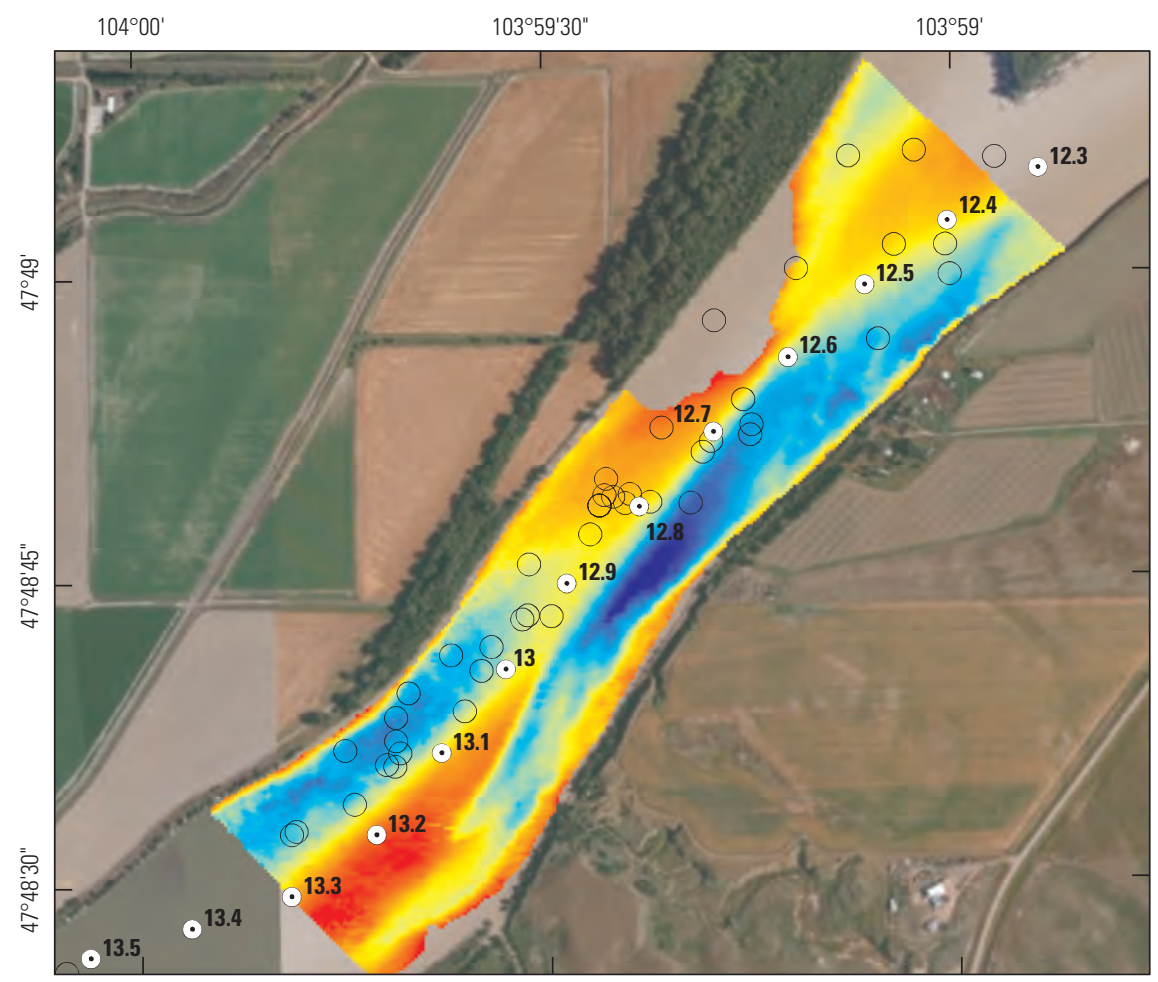

\section{EXPLANATION}

Depth, in meters

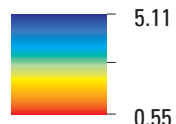

Velocity, in meters per second

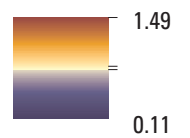

12 River-mile marker - Number is distance upstream from the confluence with the Missouri River, in miles

Sturgeon locations-Telemetry points representing fish locations from over 20 individual pallid sturgeon from June 7 through June 21, 2013

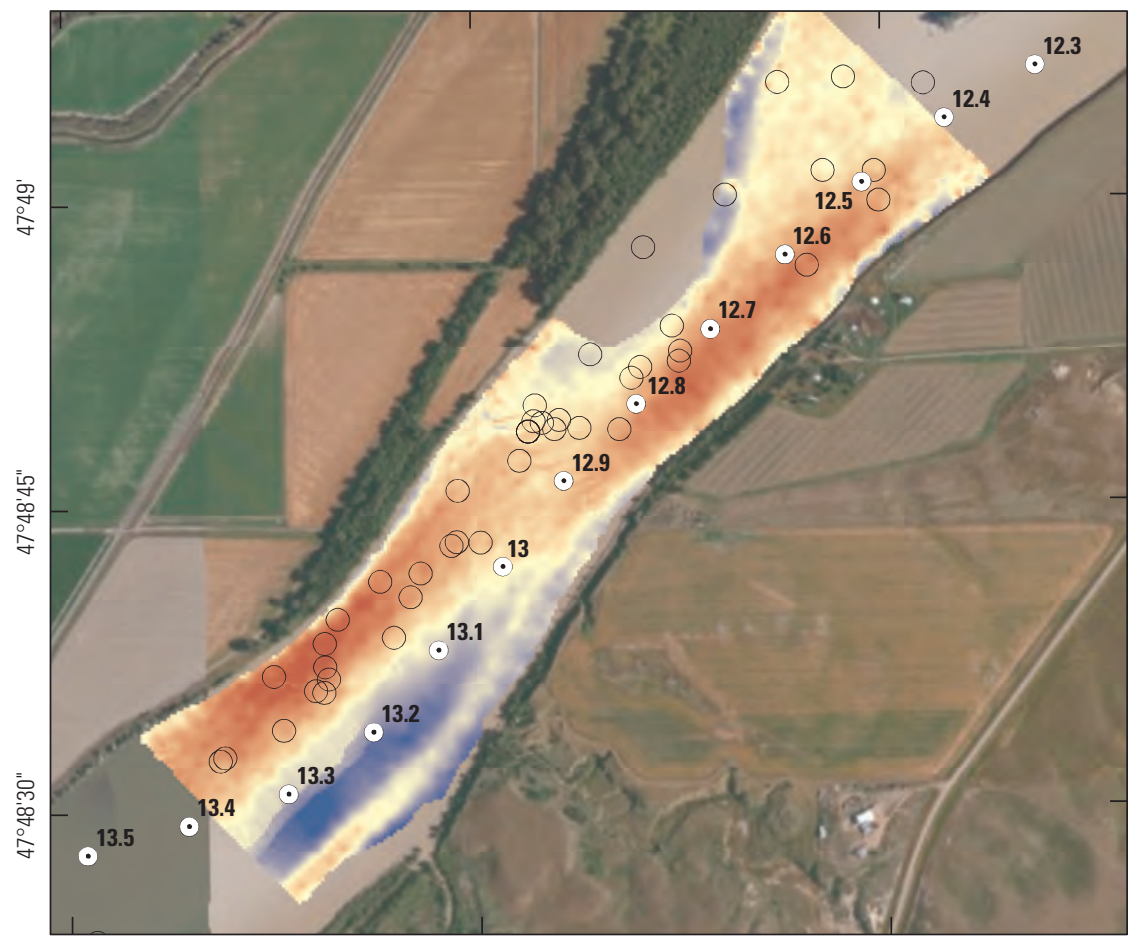

Discharge on June 21, 2013, was 22,400 cubic feet per second at the U.S. Geological Survey streamgage station Yellowstone River at Sidney, Montana

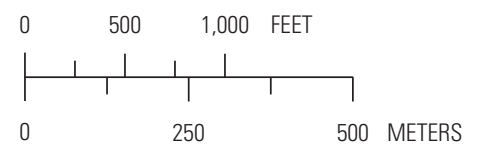

Digital Imagery from U.S. Department of Agriculture National Agriculture Imagery Program, digital data, 2010

(Applied Geomorphology, 2004)

Figure 40. Bathymetric and acoustic Doppler current profiler maps showing site where male pallid sturgeon aggregation was documented from June 7, 2013, to June 21, 2013. Discharge was approximately 22,400 cubic feet per second when mapped on June 21, 2013. 


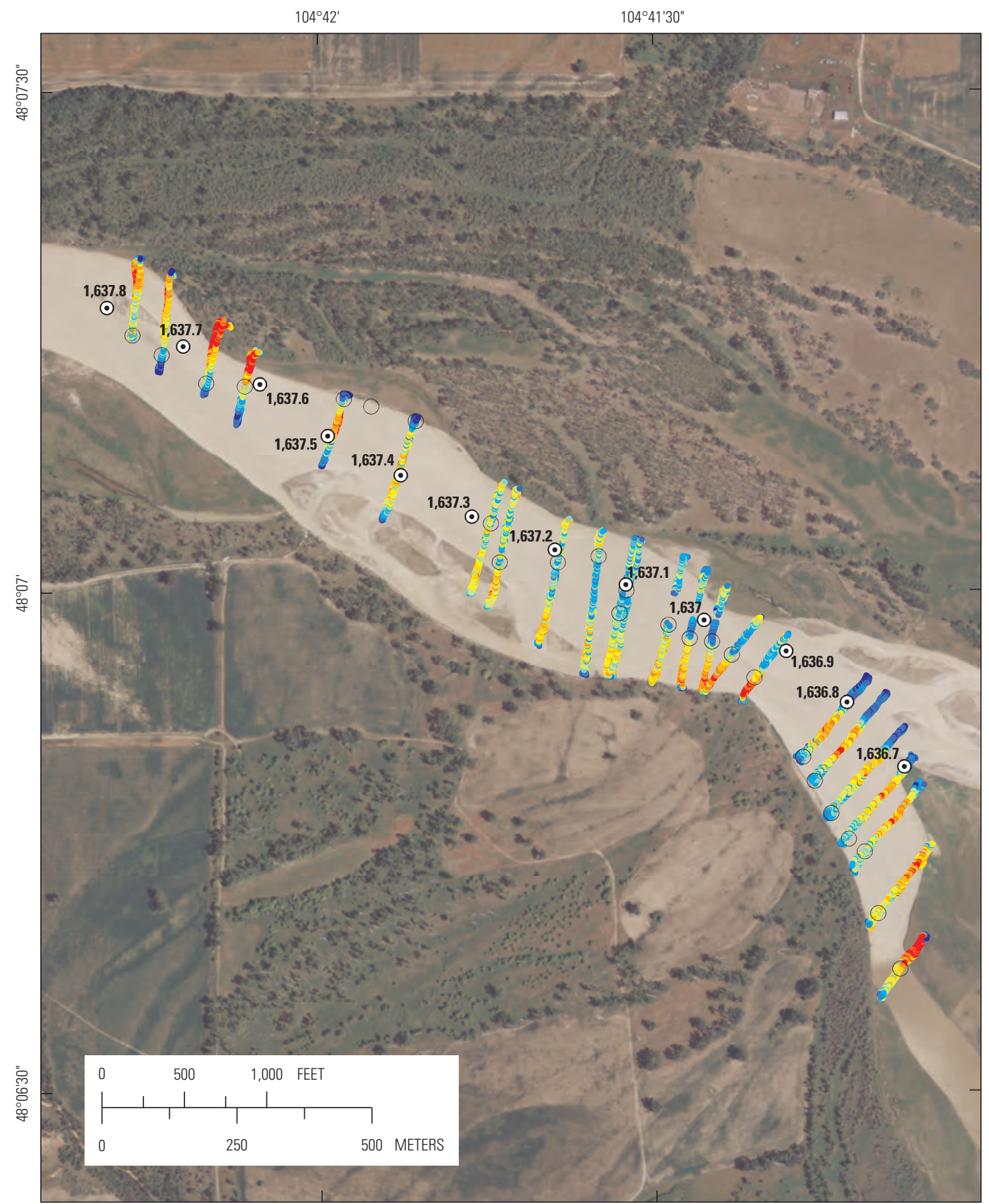

Digital imagery from U.S. Department of Agriculture National Agriculture Imagery

River miles from Yellowstone River Cumulative Impact Study, 2001 Program, digital data, 2010

\section{EXPLANATION}

Depth-averaged velocity, in meters per second

- 0.01 to 0.41

- 0.42 to 0.57

- 0.58 to 0.7

0.72 to 0.81

- 0.82 to 0.91

$$
\begin{array}{ll}
- & 0.92 \text { to } 1.00 \\
- & 1.01 \text { to } 1.10 \\
- & 1.11 \text { to } 1.21 \\
- & 1.22 \text { to } 1.35 \\
\hline & 1.36 \text { to } 1.98
\end{array}
$$

1,636 River-mile marker-Number is distance upstream from the confluence with the Mississippi River, in miles

Sturgeon locations - Telemetry points representing upstream migration fish locations for reproductive female code 41 on June 12, 2013

Figure 41. Velocities, collected with an acoustic Doppler current profiler, along migration pathway used by reproductive female code 41 on June 12, 2013. 


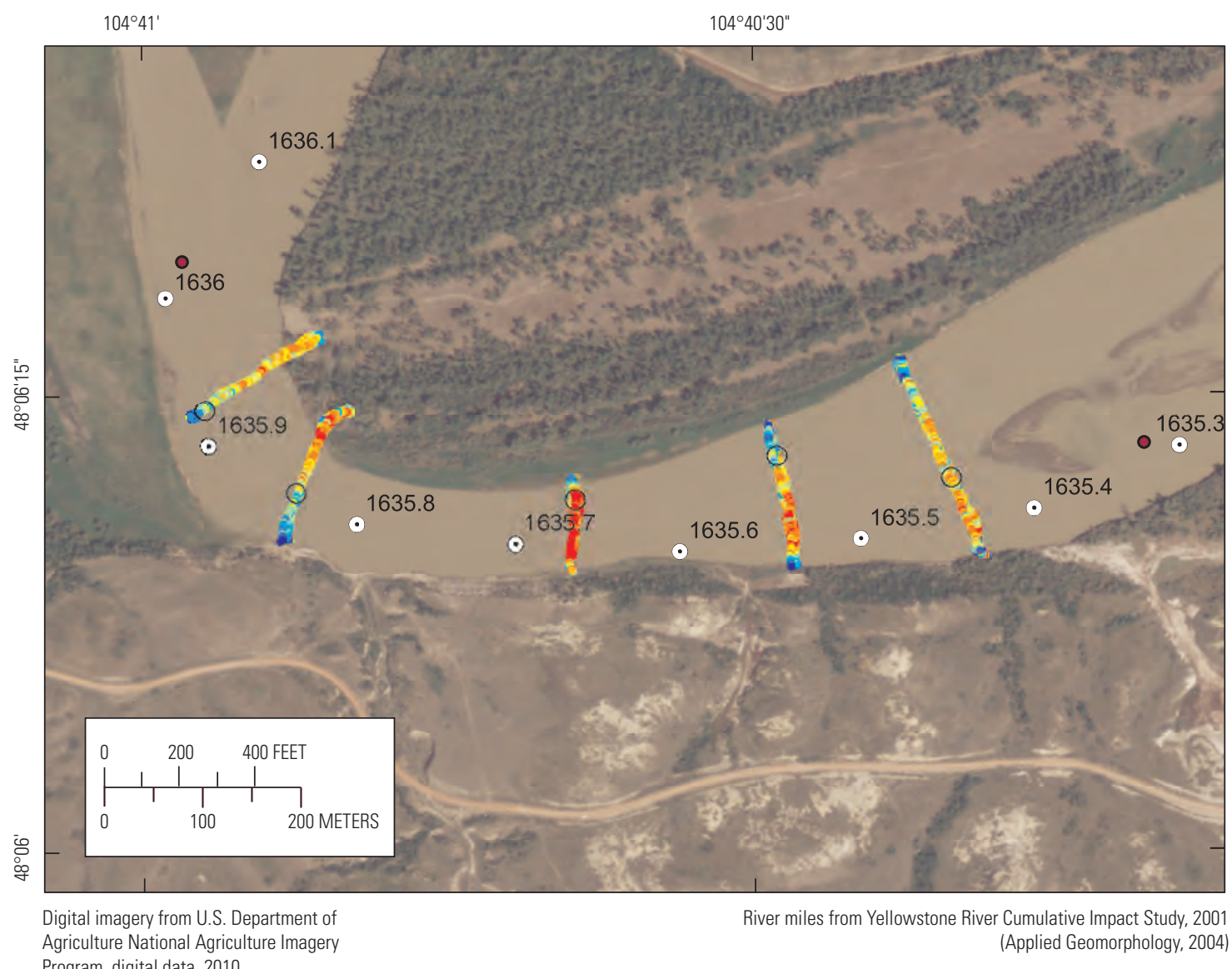

\section{EXPLANATION}

Depth-averaged velocity, in meters per second

- 0.01 to 0.41

- 0.42 to 0.57

- 0.58 to 0.71

- 0.72 to 0.81

0.82 to 0.91
0.92 to 1.00

1.01 to 1.10

- 1.11 to 1.21

- 1.22 to 1.35

- 1.36 to 1.98 $\odot^{1,636}$ River-mile marker-Number is distance upstream from the confluence with the Mississippi River, in miles

Sturgeon locations-Telemetry points representing upstream migration fish locations for reproductive female code 41 on June 12, 2013

Figure 42. Velocities, collected with an acoustic Doppler current profiler, along a second migration pathway used by reproductive female code 41 on June 12, 2013. 


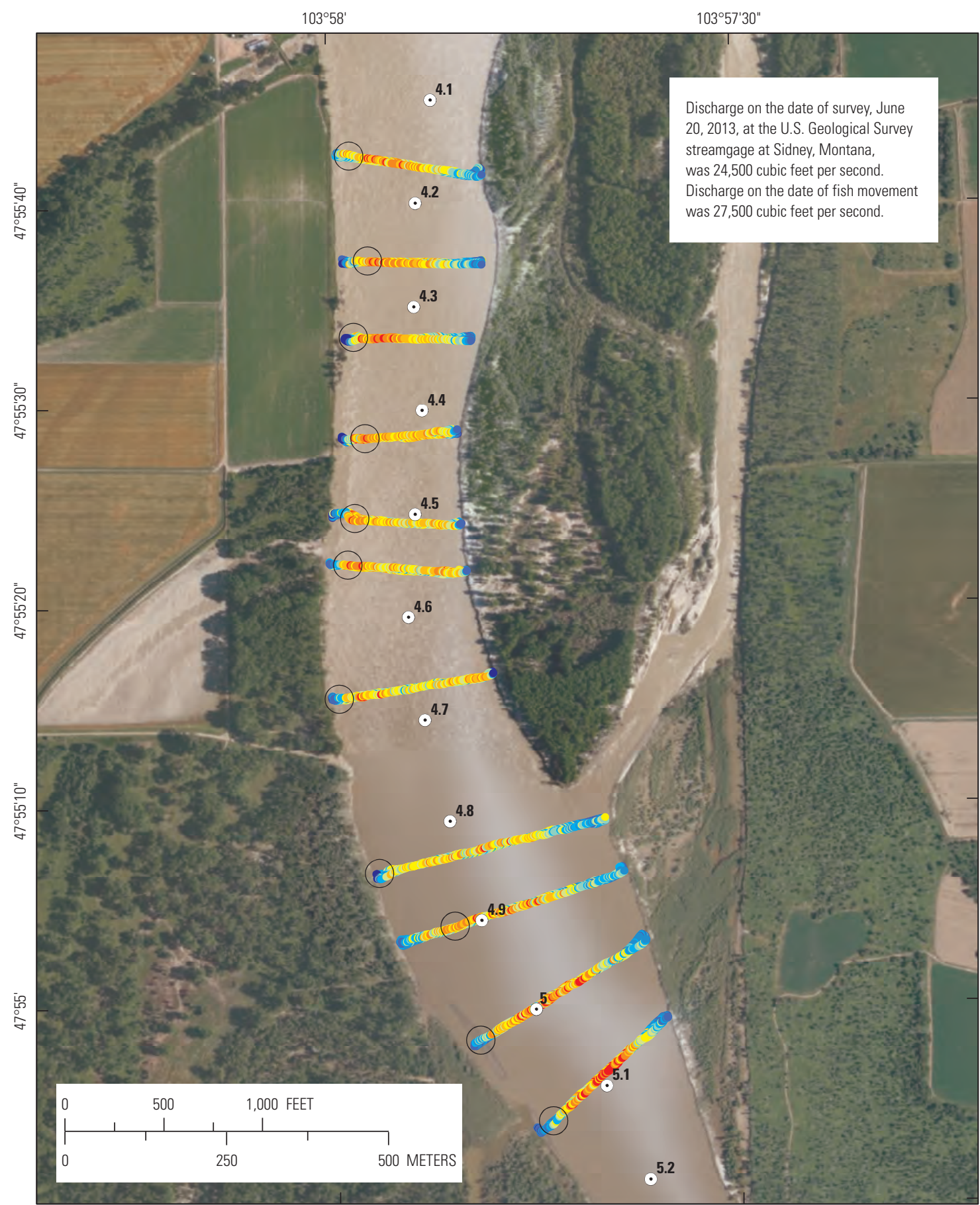

Digital imagery from U.S. Department of Agriculture National Agriculture Imagery

River miles from Yellowstone River Cumulative Impact Study, 2001 Program, digital data, 2010

\section{EXPLANATION}

Depth-averaged velocity, in meters per second

- $\quad 0.04$ to 0.27

- 0.28 to 0.46

0.47 to 0.58

0.59 to 0.69 0.70 to 0.78

\begin{tabular}{ll}
- & 0.79 to 0.86 \\
- & 0.87 to 0.93 \\
- & 0.94 to 1.01 \\
\hline & 1.02 to 1.12 \\
\hline & 1.13 to 1.57
\end{tabular}

$\overbrace{}^{\mathbf{5}}$ River-mile marker-Number is distance upstream from the confluence with the Missouri River, in miles

Sturgeon locations - Telemetry points representing upstream migration fish locations for reproductive female code 41 on June 19, 2013

Figure 43. Velocities, collected with an acoustic Doppler current profiler, along migration pathway used by reproductive female radio 41 on June 19, 2013. 

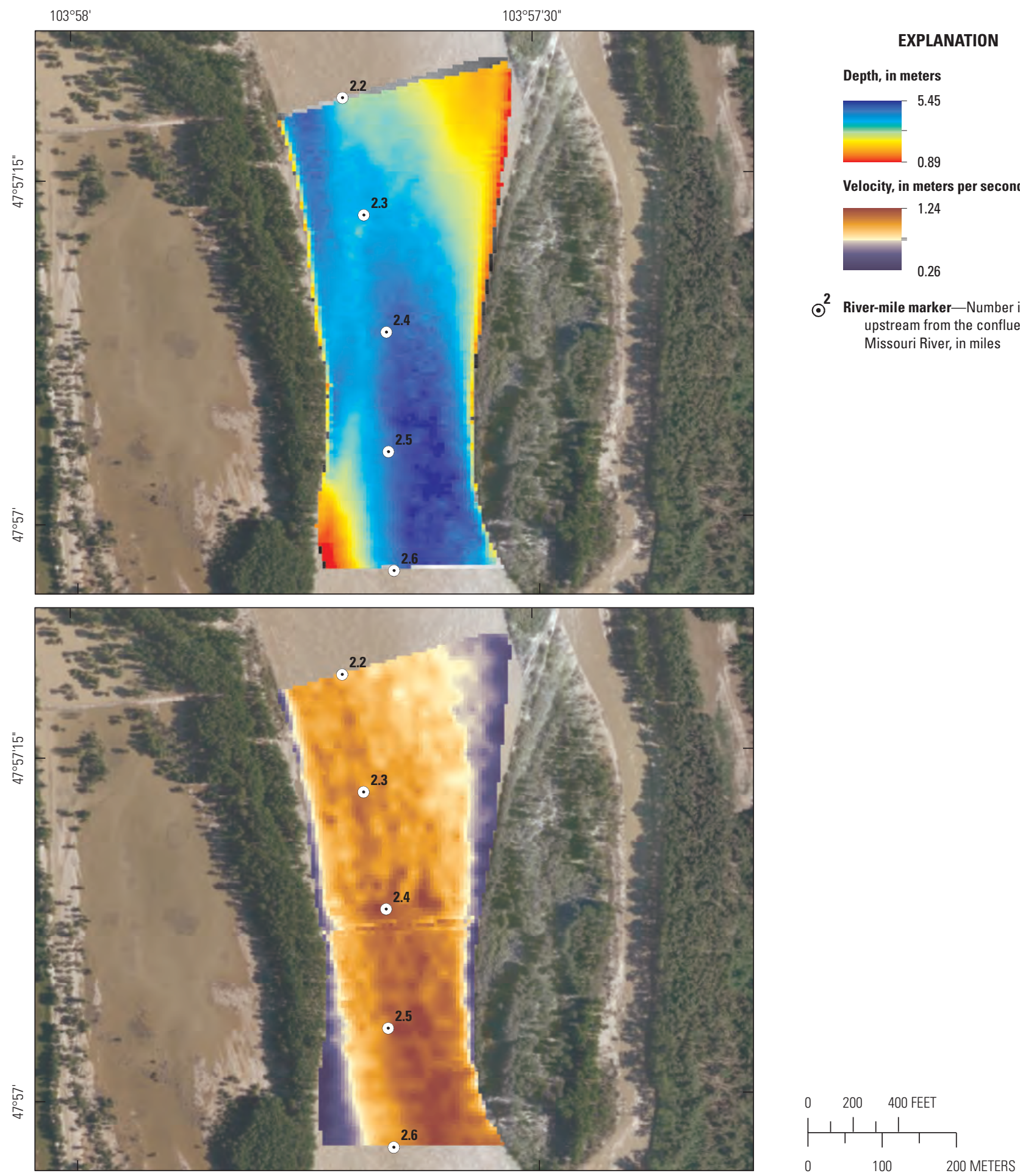

Digital imagery from U.S. Department of Agriculture National Agriculture Imagery

River miles from Yellowstone River Cumulative Impact Study, 2001 (Applied Geomorphology, 2004)

\section{EXPLANATION}

Depth, in meters

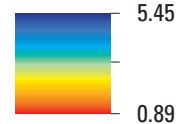

Velocity, in meters per second

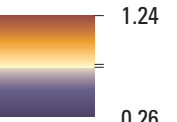

$\odot^{2}$ River-mile marker-Number is distance upstream from the confluence with the Missouri River, in miles

Figure 44. Bathymetric and acoustic Doppler current profiler maps showing sampling sites for Acipenseriformes free embryos and larvae on the Yellowstone River in 2013. 
the gravel was less than $16 \mathrm{~mm}$, classified as either fine or medium gravel. The median diameter of the largest clast sampled at this spawning location was $38 \mathrm{~mm}$ (very coarse gravel).

\section{Analysis of Drift Potential}

Velocity data was collected for dispersion analyses on 3 days on the Yellowstone River, 2 days on the Upper Missouri River upstream from the confluence of the Yellowstone River, and 1 day on the Upper Missouri River downstream from the confluence with the Yellowstone River (table 16). Measurements were collected along 275 transects total. Analysis of this data is ongoing, but preliminary results reveal that dispersion coefficients are highly variable in shallow flows where a large proportion of the vertical velocity profile is discarded. This truncation of the data results from high ADCP error inherent in velocity measurements using ADCPs in the near-bed region because of side lobe reflection from the bottom. Additionally, in broad, shallow reaches of the Yellowstone and Upper Missouri Rivers, high variation in dispersion coefficients results from local topographic variability, especially at those locations with submerged midchannel bars. Thus, we observe great variability in dispersion coefficients over short longitudinal distances and reach averaged values of dispersion coefficients may not reflect local potential for dispersion and retention.

\section{Database Integration, GIS Support, Coordination, and Outreach}

The CSRP for the Upper Missouri and Yellowstone Rivers involves simultaneous data collection from multiple field crews requiring the need for a standardized data collection platform. The SIMS framework was developed by the USGS for data collection and maintenance using a range of software and hardware products to manage the volume and diversity of data collected by the CSRP.

The general objectives are an extension of data integration described in Task 1 and are to (1) develop and deploy a standardized mobile mapping and electronic data-collection framework to support simultaneous data collection from the Upper Missouri and Yellowstone Rivers, and (2) compile and maintain these data collected for the CSRP.

\section{Methods}

The highly customized SIMS mobile mapping and electronic data collection application was adapted to collect telemetry data in the Upper Missouri and Yellowstone Rivers. Numerous ancillary data layers (for example, aerial photography and river mile datasets) were obtained or created to provide field staff with a visual reference of their spatial location during data collection. Custom data layers and tools were developed or modified to streamline data collection in the Upper Missouri and Yellowstone Rivers. Numerous measures were used to ensure accuracy and increase efficiency of data collection by field staff. Drop-down menus presenting predefined lists of choices were used as often as practical. Scripts and validation rules were written to verify data during the collection process to eliminate as many errors as possible. If an entered value falls outside the expected range, a pop-up error message prompts field staff to review the entered value. Telemetry data are transmitted to and archived at CERC. Incoming data from multiple crews were compiled and incorporated into the master geospatial dataset. These data were then validated for accuracy and completeness at the end of the spawning season.

Table 16. Summary table for measurements made in 2013 specifically for dispersion calculations.

[Mont., Montana; ADCP, acoustic Doppler current profiler]

\begin{tabular}{llclcc}
\hline $\begin{array}{c}\text { Date } \\
\text { (month/ } \\
\text { day/year) }\end{array}$ & River & $\begin{array}{c}\text { River mile } \\
\text { location }\end{array}$ & \multicolumn{1}{c}{$\begin{array}{c}\text { Nearest } \\
\text { streamgage }\end{array}$} & $\begin{array}{c}\text { Discharge, } \\
\text { in cubic feet } \\
\text { per second } \\
\left.\text { (ft }{ }^{3} / \mathbf{s}\right)\end{array}$ & $\begin{array}{c}\text { Survey } \\
\text { type }\end{array}$ \\
\hline $6 / 9 / 2013$ & Yellowstone River & $1.1-3.0$ & Sidney, Mont. & 20,600 & ADCP \\
$6 / 9 / 2013$ & Missouri River & $1548.3-1548.4$ & Culbertson, Mont. & 20,100 & ADCP \\
$6 / 10 / 2013$ & Yellowstone River & $58.3-72.1$ & Sidney, Mont. & 20,500 & ADCP \\
$6 / 11 / 2013$ & Yellowstone River & $41.1-47.0$ & Sidney, Mont. & 22,600 & ADCP \\
$6 / 12 / 2013$ & Missouri River & $1626.0-1627.0$ & Culbertson, Mont. & 19,200 & ADCP \\
$6 / 19 / 2013$ & Missouri River & $1566.9-1578.8$ & $\left({ }^{1}\right)$ & 46,600 & ADCP \\
\hline
\end{tabular}

${ }^{1}$ Discharge for the survey conducted on June 19, 2013, was calculated by summing the discharges recorded at Sidney, Mont. and Culbertson, Mont. 
Table 17. Number and percent telemetry locations recorded in the Upper Missouri and Yellowstone Rivers per month during 2013.

\begin{tabular}{lcccc}
\hline Month & $\begin{array}{c}\text { Number of } \\
\text { Missouri River } \\
\text { locations }\end{array}$ & $\begin{array}{c}\text { Number of } \\
\text { Yellowstone River } \\
\text { locations }\end{array}$ & $\begin{array}{c}\text { Total } \\
\text { number of } \\
\text { locations }\end{array}$ & $\begin{array}{c}\text { Percent } \\
\text { total } \\
\text { locations }\end{array}$ \\
\hline April & 37 & 24 & 61 & 8.4 \\
May & 41 & 81 & 122 & 16.8 \\
June & 108 & 321 & 429 & 59.2 \\
July & 13 & 10 & 23 & 3.2 \\
August & 5 & 1 & 6 & 0.8 \\
September & 28 & 0 & 28 & 3.9 \\
October & 56 & 0 & 56 & 7.7 \\
\hline
\end{tabular}

\section{Progress and Results}

The SIMS mobile mapping application was deployed on ruggedized laptop computers to record geospatial data detailing pallid sturgeon telemetry locations in the Upper Missouri and Yellowstone Rivers. From April 18 through October 23, 2013, telemetry locations for 725 pallid sturgeon were recorded by USGS and MFWP research crews for Tasks 2 and 3. Telemetry locations were recorded for 103 uniquely coded adult and juvenile pallid sturgeon. The mean number of locations per individual telemetry code was 6.9 and ranged from 1 to 67 . Most telemetry locations were recorded during the spring spawning season in May and June, 122 (16.8 percent) and 429 (59.2 percent) locations, respectively (table 17). A total of 437 ( 60.3 percent) telemetry locations were recorded in the Yellowstone River, the remaining 288 (39.7 percent) telemetry locations were recorded in the Missouri River. These telemetry data are integral to visualizing, analyzing, and understanding the migration patterns and habitat use of pallid sturgeon in the Yellowstone and Upper Missouri Rivers.

\section{Discussion}

The SIMS mobile mapping application records and validates data at the point of contact. The ability to rapidly and accurately capture data in the field improves data accuracy and reduces data-entry and post-processing time. Additionally, the SIMS mobile mapping application allows researchers to transport complex ancillary datasets into the field, which further enhances and supports the data collection experience of field researchers by providing access to a wide variety of specialized data (Tripcevich, 2004).

\section{Task 3. Examination of Pallid Sturgeon Use, Migrations and Spawning in the Milk River and Missouri River below Fort Peck Dam during 2013}

The Lower Yellowstone River and Missouri River between Fort Peck Dam and Lake Sakakawea is inhabited by a wild adult population of federally endangered pallid sturgeon (Scaphirhynchus albus). For the last two decades, pallid sturgeon in this section of the Upper Missouri River Basin have been the focus of several studies examining movements, migrations, and habitat use (Bramblett and White, 2001; Fuller and others, 2008; Fuller and Braaten, 2012).

In 2011, record setting snowfall coupled with record spring rains resulted in rapid filling of Fort Peck Reservoir above full pool and subsequently releasing water over the Fort Peck Spillway. The resulting hydrologic regime in the Missouri River downstream from Fort Peck Dam during 2011 was unique among the last several years. This reach was affected by unusual spillway releases, increased discharge from the Fort Peck Powerhouses, and elevated tributary discharge conditions during spring and early summer from the Milk River. This resulted in an increased use by adult pallid sturgeon (DeLonay and others, 2014) and hatchery reared juvenile pallid sturgeon (Hunziker and others, 2013) in the reach of the Missouri River from Fort Peck Dam to Wolf Point, Montana. Additionally, an aggregation of adult pallid sturgeon was located just downstream from the Milk River and the first genetically confirmed wild produced pallid sturgeon free embryo was collected in this reach as a result of these flows (DeLonay and others, 2014). Additional information is being collected to determine the flow regimes needed to trigger migrations and spawning of pallid sturgeon in the Missouri River below Fort Peck Dam. This study will focus on evaluating use, migrations, and spawning of pallid sturgeon in the Milk River and Missouri River downstream from Fort Peck Dam.

The Missouri River study area extended from Fort Peck Dam located at river mile 1,770 downstream to river mile 1,553.5 (near Williston, North Dakota; fig. 45). The study area also included the lower 115 miles of the Milk River from Vandalia Dam to its confluence with the Missouri River.

The objectives of this work were to (1) assess pallid sturgeon migrations and use of the Milk River and Missouri River between Fort Peck Dam and the Yellowstone River confluence; (2) quantify reproductive products (eggs, free embryos, larvae) and potential spawning reaches in the Milk River and Missouri River below Fort Peck Dam; and (3) assess and quantify settlement of pallid sturgeon larvae from the drift based on collections of young-of-year pallid sturgeon in lower reaches of the Missouri River. 


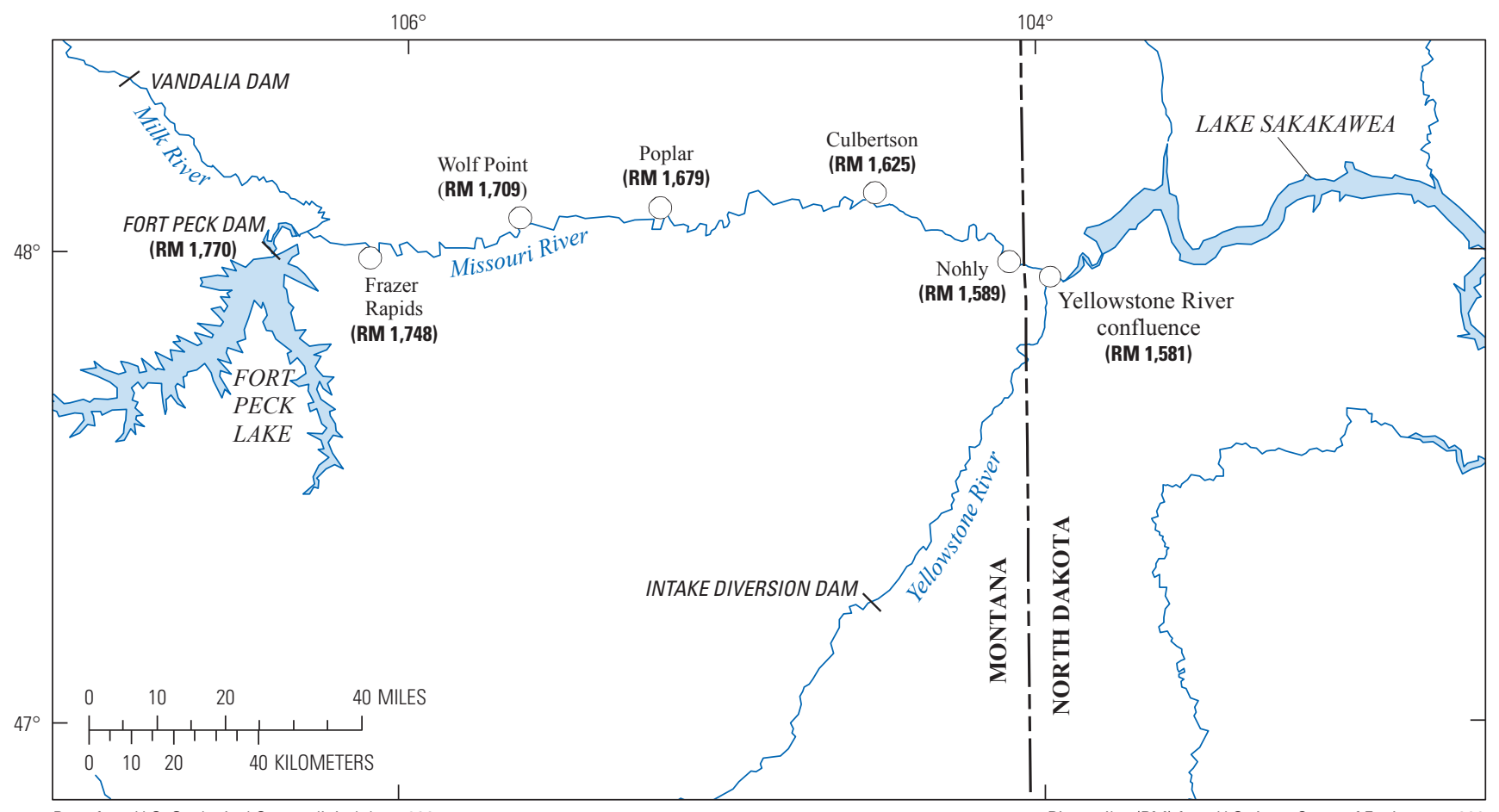

Base from U.S. Geological Survey digital data, 2004 Universal Transverse Mercator projection Zone 13

Figure 45. Study area of the Missouri River, Milk River and Lower Yellowstone River.

\section{Methods}

Pallid sturgeon were sampled using drifted trammel nets and were implanted with digitally coded radio transmitters (MCFT-3L tags, $16 \mathrm{~mm} \times 73 \mathrm{~mm}$, air weight = $26 \mathrm{~g}$, 2,929-day longevity, 5-second pulse interval, 149.760 Megahertz (Mhz), Lotek Wireless Incorporated, New Market, Ontario). The signal from each transmitter is encoded with a unique digital identification code (code) to facilitate identification of individual fish. New transmitters used at reimplantation have a different code than the expired tags they replace. Sturgeon reimplanted multiple times will have multiple codes through time. Surgical procedures followed methods outlined in Braaten and Fuller (2005). Most fish were collected in previous years during broodstock collection near the confluence of the Missouri and Yellowstone Rivers.

Manual tracking of fish by boat during 2013 was begun in April. The Missouri River between Fort Peck Dam and Wolf Point (70 m) was tracked from April through October. The Milk River was only manually tracked when the groundbased telemetry station, located near the mouth, indicated that a fish had crossed it (see, "Progress and Results"). One radio frequency $(149.760 \mathrm{MHz})$ was monitored during the boattracking run using a 4-element Yagi antennae. Several variables (including radio frequency, code, latitude, longitude, and time-of-day) were recorded at fish locations.

Stationary telemetry logging stations were deployed in April 2013 at river mile 1,760, 1,720, 1,618; and 1,584 of the
Missouri River. An additional receiver was located on the Milk River, about 2.5 miles upstream from the confluence with the Missouri River (fig. 45). Additionally, there were several sites on the Yellowstone River that are mentioned in Task 2 in this report. The logging stations were placed on shore with two 4-element Yagi antennae facing upstream and downstream. Each logging station was equipped with a battery powered receiver (Lotek SRX-400), solar panel, an environmental enclosure kit containing dual 12-volt batteries, and an antenna switchbox. Data recorded by the logging stations were downloaded to a laptop computer two times per month between April and October. Coupled with manual tracking efforts, the array of telemetry logging stations facilitated detection of dates and times of movement events between and within rivers and river reaches.

The Lower Milk River and Upper Missouri River were sampled for free embryos near Wolf Point following methods outlined in Braaten and Fuller (2010). Sampling was performed two times per week at multiple replicate locations. After sampling was completed, net contents were transferred to black rubber trays where Acipenseriformes free embryos (sturgeon and paddlefish) were extracted from the detritus. Extracted Acipenseriformes free embryos were placed immediately in 95 percent nondenatured ethanol for genetic analysis. After extracting these free embryos, the remaining sample was placed in a 10 percent formalin solution containing phloxine-B dye and contents were separated and identified in the laboratory. 
Targeted sampling for young-of-year pallid sturgeon (larvae and juveniles spawned within the year) followed trawling methods outlined in Braaten and Fuller (2007). Samples were collected every week from late July through early September. Young-of-year sturgeon (Scaphirhynchus spp.) were sampled with a benthic (beam) trawl in the Upper Missouri River above the confluence with the Yellowstone River and the Upper Missouri River below the confluence with the Yellowstone River. Four replicate sampling locations were established at each site where each replicate was comprised of an inside bend, outside bend, and channel crossover habitat complex associated with a river bend. Fin clips were obtained for all Scaphirhynchus spp. collected, and stored in 95 percent ethanol (U.S Fish and Wildlife Service, 2012). Free-embryo and young-of-year samples were submitted for genetic analysis to distinguish individuals as pallid sturgeon or shovelnose sturgeon.

\section{Progress and Results}

Contributions from the Milk River augmented regulated releases from Fort Peck Dam and had major effects on seasonal flow patterns in the Missouri River (fig. 46). For example, elevated discharge in the Milk River during June resulting from rainfall in the watershed was reflected in elevated discharge conditions at Wolf Point and Culbertson, Montana. Discharge $>20,000 \mathrm{ft}^{3} / \mathrm{sec}$ was recorded at Culbertson during this period, which is a rare event. In addition to discharge patterns, Milk River contributions had a strong effect on water temperature and turbidity regimes in the Missouri River (fig. 47). During the increased June discharge from the Milk River, temperature in the Missouri River at Nickels increased from $7{ }^{\circ} \mathrm{C}$ to $15^{\circ} \mathrm{C}$.

For objective 1, telemetered wild adult pallid sturgeon $(n=46)$ were manually tracked in the Missouri River upstream of the Yellowstone River confluence to Fort Peck Dam. Of these 46 fish, 2 were gravid females, 5 were nonreproductive females, and 39 were males. Pallid sturgeon made increased use of the Missouri River above the confluence with the Yellowstone River during three periods (fig. 48).

First, during early May, approximately 46 percent of individuals were located above the Yellowstone River confluence. This is the highest proportion of fish that has been documented in the past decade. However, most forays upstream in the Missouri River above the confluence with the Yellowstone River were generally less than 40 miles (fig. 49). Yellowstone River discharge was approximately $5,000 \mathrm{ft}^{3} / \mathrm{sec}$ and Missouri River discharge was 10,000 $\mathrm{ft}^{3} / \mathrm{sec}$ (fig. 46).

Second, in mid-June, when discharge of the Missouri River was approximately $20,000 \mathrm{ft}^{3} / \mathrm{sec}$, upstream migrations of greater distances (120-180 miles) occurred. Four males and the two gravid females (codes 40 and 41) migrated up the Missouri River during this time. Code 41 was initially assessed in the Missouri River below the confluence with the Yellowstone River on April 25 and her eggs had a polarity index (PI) of 0.196. She was assessed on June 17 upstream from Wolf Point (river mile 1709) and had not spawned (eggs had a PI of 0.07). This fish migrated downstream in the Missouri River and spawned in the Yellowstone River on June 21 (see Task 2 for details). Code 40 was initially assessed on May 15 in the Missouri River just upstream from the Yellowstone River and her

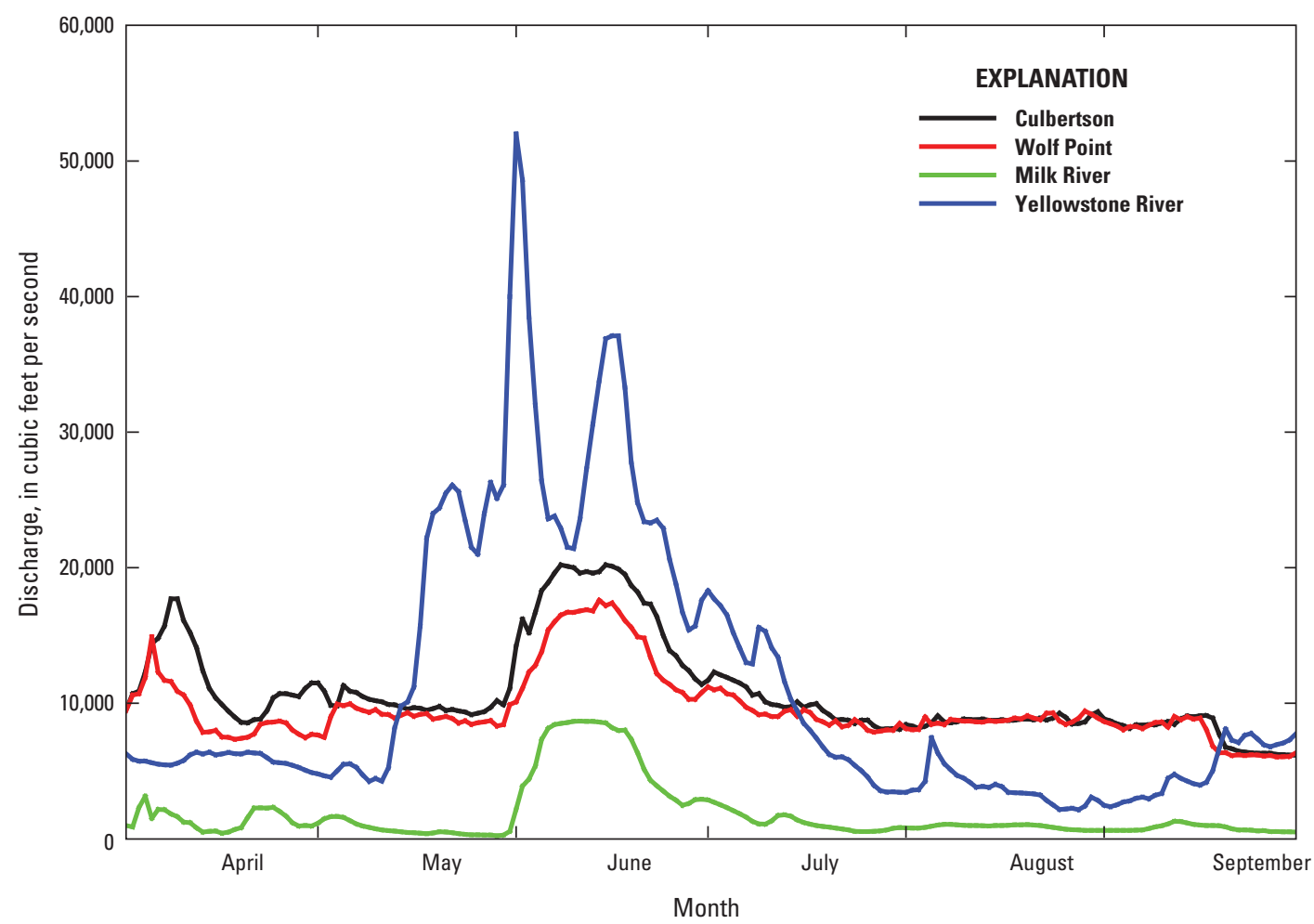

Figure 46. Mean daily discharge in the Missouri River at Culbertson, Montana (streamgage 06185500), Missouri River at Wolf Point, Montana (streamgage 06177000), and in the Milk River at Nashua, Montana, (streamgage 06174500) and in the Yellowstone River at Sidney, Montana (streamgage 06329500) during 2013. 


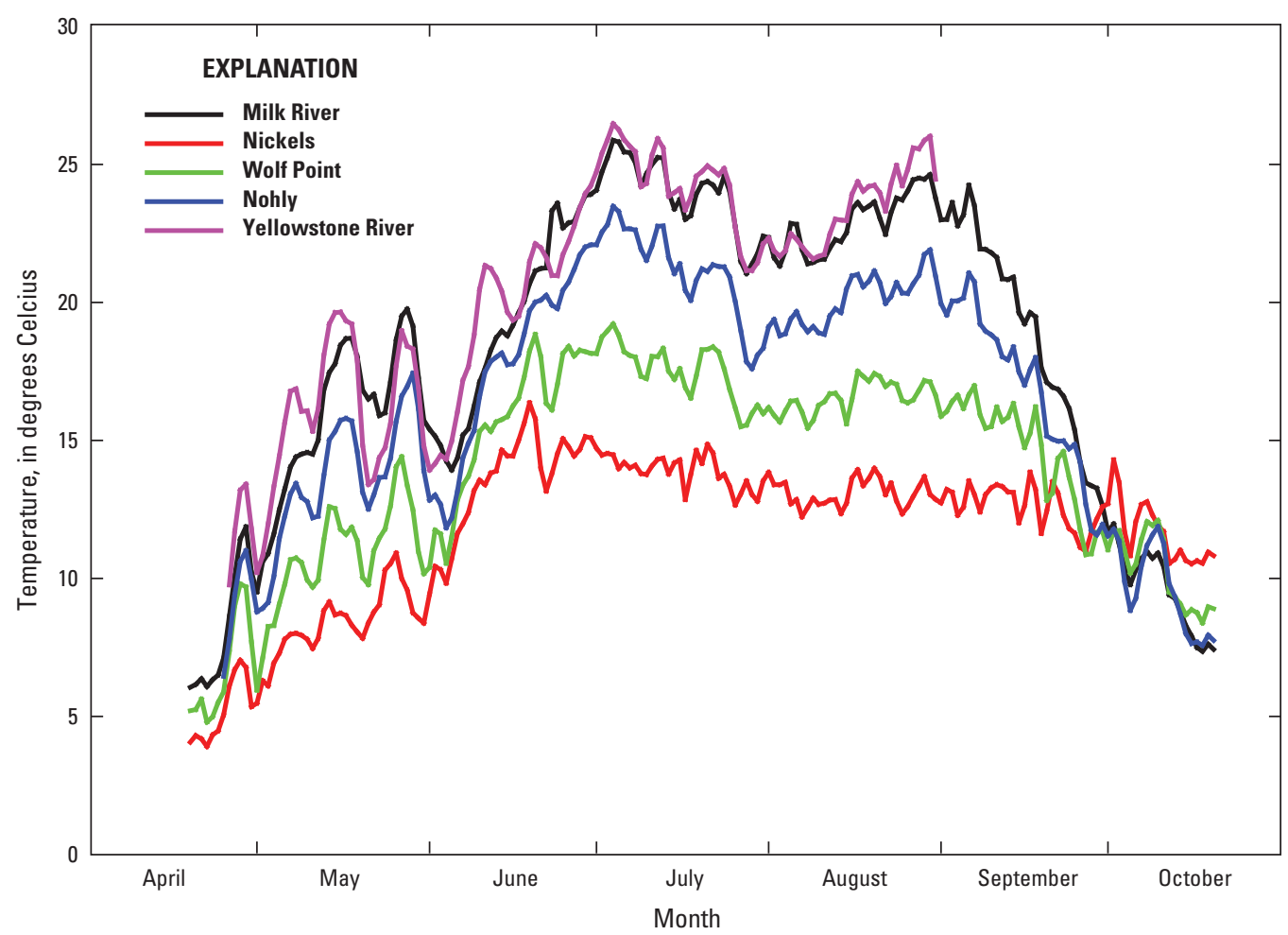

Figure 47. Temperature $\left({ }^{\circ} \mathrm{C}\right)$ at Nickels, Wolf Point, and Nohly in the Missouri River, Milk River and Yellowstone River during 2013.

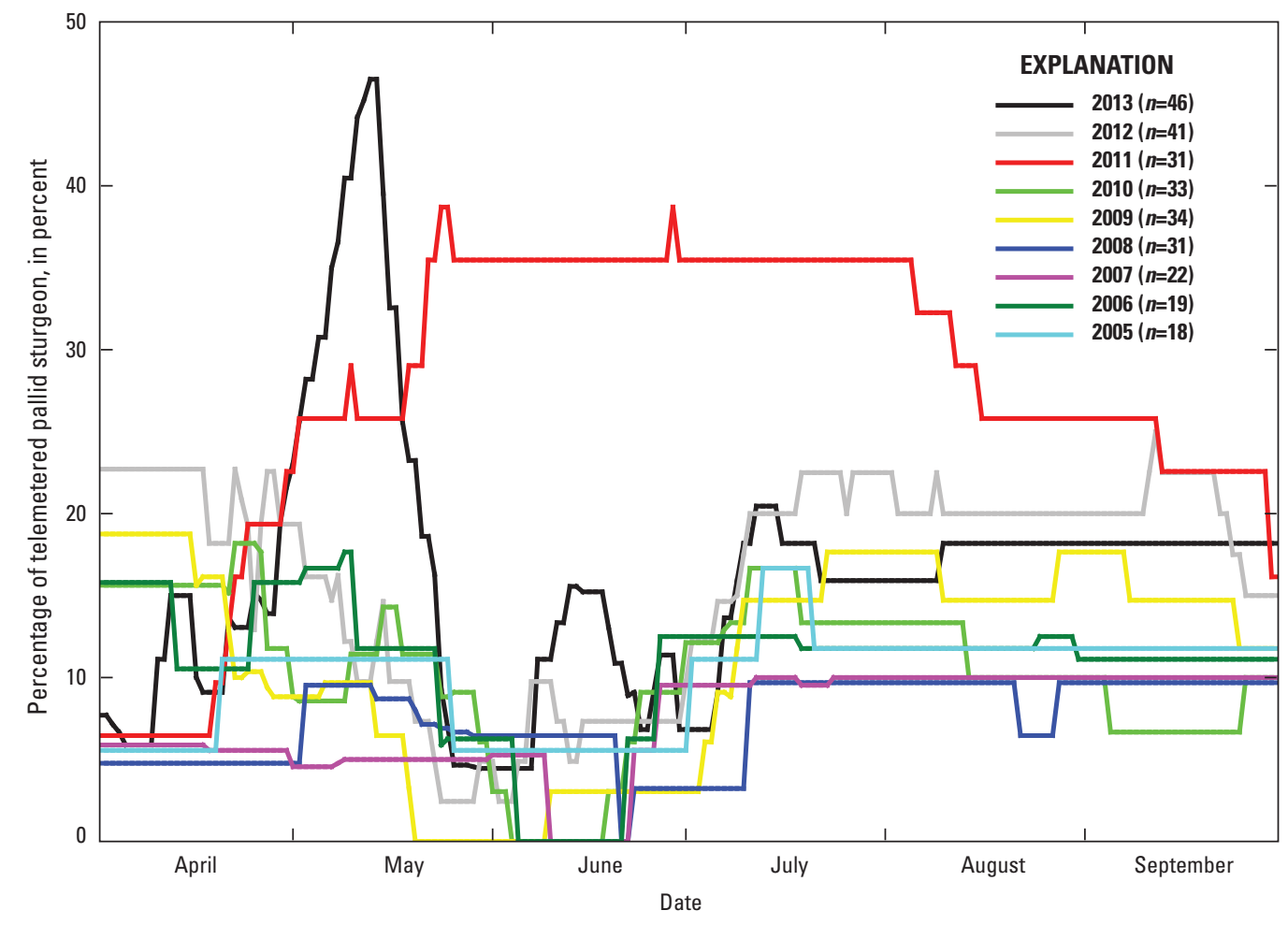

Figure 48. Percentage (\%) of telemetered adult pallid sturgeon located in the Missouri River above the confluence of the Yellowstone River by date from 2005 to 2013. $N=$ number of implanted individuals. 


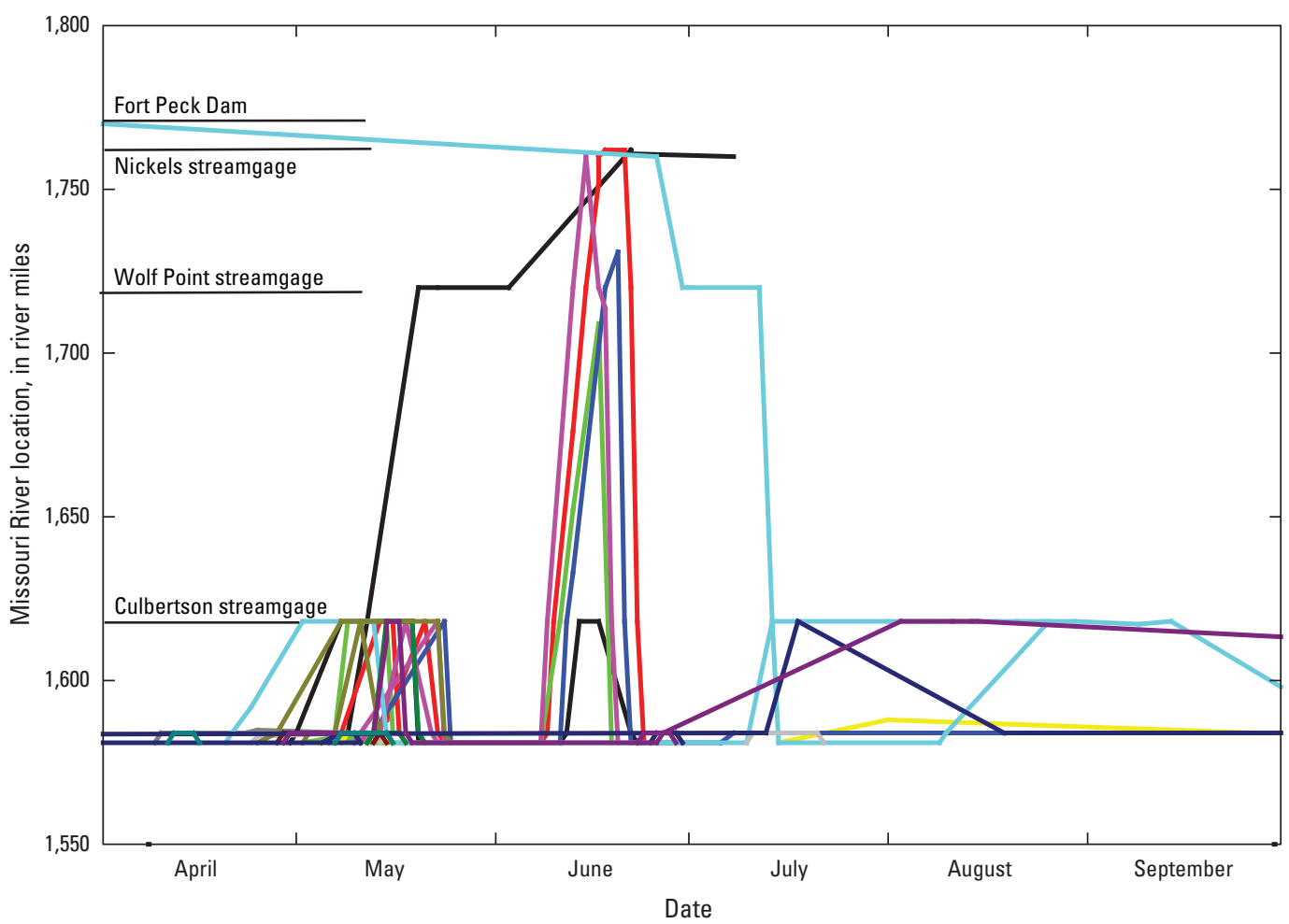

Figure 49. Locations (river mile) of 29 different telemetered pallid sturgeon that used the Missouri River above the Yellowstone River confluence in 2013. River mile 1581 is the confluence of the Yellowstone River, river mile 1762 is the Milk River confluence, and river mile 1770 is Fort Peck Dam.

Table 18. Sampling dates and paddlefish (Polyodon spathula) free embryos collected in the Milk River in 2013.

\begin{tabular}{cccccccccc}
\hline Date & $\mathbf{6 / 1 0 / 2 0 1 3}$ & $\mathbf{6 / 1 2 / 2 0 1 3}$ & $\mathbf{6 / 2 1 / 2 0 1 3}$ & $\mathbf{6 / 2 5 / 2 0 1 3}$ & $\mathbf{6 / 2 7 / 2 0 1 3}$ & $\mathbf{7 / 2 / 2 0 1 3}$ & $\mathbf{7 / 4 / 2 0 1 3}$ & $\mathbf{7 / 9 / 2 0 1 3}$ & $\mathbf{7 / 1 2 / 2 0 1 3}$ \\
\hline Paddlefish & 0 & 1 & 86 & 3 & 0 & 0 & 0 & 0 & 0 \\
\hline
\end{tabular}

eggs had a PI of 0.10. She migrated 72 miles to Intake Dam on the Yellowstone River on June 4. Then she reversed direction and moved rapidly out of the Yellowstone River and 180 miles up the Missouri River, and into the Milk River where she was located on June 18. She was recaptured and assessed as she exited the Milk River on June 21. She was determined to not have spawned. Eggs collected during a biopsy had a PI of 0.05. She then migrated out of the Missouri River and was caught in the act of spawning in the Yellowstone River on June 25 (see Task 2 for details). In addition to code 40, elevated discharge in the Milk River during mid-June resulted in a male (code 15) and a telemetered hatchery-reared juvenile pallid sturgeon using the Milk River.

Lastly, use of the Missouri River above the Yellowstone confluence increased in July, similar to other years, as fish completed spawning in the Yellowstone River and migrated to post-spawn areas in the Missouri River above and below the confluence of the Yellowstone River where most would eventually overwinter.
For objective 2, the Milk River was sampled for free embryos during nine events spanning from June 10 through July 12, 2013. No sturgeon free embryos were collected during this time; however, 90 paddlefish were collected, 86 of these were collected on June 21 (table 18).

The Missouri River was sampled for free embryos near Wolf Point during 18 events from June 4 through August 9. A total of 205 paddlefish free embryos and 61 Scaphirhynchus free embryos were collected (table 19). No pallid sturgeon were identified among the samples collected (Dr. Edward Heist, Southern Illinois University Carbondale, written commun., 2014). Although not corrected for effort at this time, these are the highest collections of paddlefish and sturgeon free embryos from the Missouri River since 2001 when an intense free-embryo sampling protocol took place.

For objective 3 , beam trawling for young-of-year sturgeon was done weekly from July 31 through September 3, 2013. Channel catfish (Ictalurus punctatus), sicklefin chub (Macrhybopsis meeki) and sturgeon chub (Macrhybopsis gelida) made up 54 percent, 13 percent and 12 percent of the 
Table 19. Sampling dates and paddlefish (Polyodon spathula) and sturgeon (Scaphirhynchus spp.) free embryos collected in the Missouri River near Wolf Point in 2013.

\begin{tabular}{lcc}
\hline \multicolumn{1}{c}{ Date } & Paddlefish & Sturgeon \\
\hline $6 / 4 / 2013$ & 0 & 0 \\
$6 / 6 / 2013$ & 0 & 0 \\
$6 / 11 / 2013$ & 0 & 0 \\
$6 / 20 / 2013$ & 93 & 0 \\
$6 / 24 / 2013$ & 37 & 0 \\
$6 / 26 / 2013$ & 44 & 0 \\
$7 / 1 / 2013$ & 5 & 7 \\
$7 / 3 / 2013$ & 17 & 9 \\
$7 / 8 / 2013$ & 2 & 3 \\
$7 / 10 / 2013$ & 7 & 3 \\
$7 / 15 / 2013$ & 0 & 1 \\
$7 / 17 / 2013$ & 0 & 4 \\
$7 / 22 / 2013$ & 0 & 14 \\
$7 / 24 / 2013$ & 0 & 8 \\
$7 / 29 / 2013$ & 0 & 3 \\
$8 / 2 / 2013$ & 0 & 3 \\
$8 / 5 / 2013$ & 0 & 1 \\
$8 / 9 / 2013$ & 0 & 5 \\
\hline & &
\end{tabular}

catch, respectively (table 20). A total of 85 young-of-year sturgeon was collected in the Missouri River below the confluence with the Yellowstone River and 26 were collected in the Missouri River above the confluence. A total of 107 sturgeon were submitted for genetic analysis. None were confirmed to be pallid sturgeon (Dr. Edward Heist, Southern Illinois University Carbondale, written commun., 2014).

Although some of the young-of-year sturgeon were larger and likely produced in the Yellowstone River, most fish were smaller and were likely produced in the Missouri River (table 21). This theory is further supported by the fact that free embryos were still being collected in the Missouri River into August, whereas no larvae were found in the Yellowstone River after mid-June.

\section{Discussion}

During 2013, high June flows from the Milk River augmented Missouri River discharge and reached 20,000 ft $\mathrm{ft}^{3} / \mathrm{s}$ near the Yellowstone River confluence. Adult pallid sturgeon responded by migrating above Wolf Point and some made forays into the Milk River. It is intriguing that pallid sturgeon responded to flows of this magnitude. The only other year when substantial migrations were made into the Missouri
Table 20. Total catch of fish by the benthic trawl in the Missouri River above the confluence of the Yellowstone River, Missouri River below the confluence of the Yellowstone River, and total catch from July 31 to September 4, 2013.

[ATC, above the confluence of the Yellowstone River; BTC, below the confluence of the Yellowstone River]

\begin{tabular}{|c|c|c|c|}
\hline Species & ATC & BTC & Total \\
\hline Common carp (Cyprinus carpio) & 1 & 5 & 6 \\
\hline Channel catfish (Ictalurus punctatus) & 44 & 888 & 932 \\
\hline Emerald shiner (Notropis atherinoides) & 5 & 12 & 17 \\
\hline Flathead chub (Platygobio gracilis) & 4 & 13 & 17 \\
\hline Fathead minnow (Pimephales promelas) & 0 & 1 & 1 \\
\hline Freshwater drum (Aplodinotus grunniens) & 2 & 3 & 5 \\
\hline Goldeye (Hiodon alosoides) & 1 & 35 & 36 \\
\hline Green sunfish (Lepomis cyanellus) & 2 & 1 & 3 \\
\hline Longnose dace (Rhinichthys cataractae) & 1 & 2 & 3 \\
\hline Number of trawls without fish & 14 & 9 & 23 \\
\hline Pallid sturgeon (Scaphirhynchus albus) ${ }^{1}$ & 2 & 9 & 11 \\
\hline River carpsucker (Carpiodes carpio) & 1 & 1 & 2 \\
\hline Sicklefin chub (Macrhybopsis meeki) & 58 & 170 & 228 \\
\hline Sturgeon chub (Macrhybopsis gelida) & 78 & 139 & 217 \\
\hline Sauger (Sander canadensis) & 2 & 10 & 12 \\
\hline $\begin{array}{l}\text { Shorthead redhorse (Moxostoma macro- } \\
\text { lepidotum) }\end{array}$ & 1 & 0 & 1 \\
\hline $\begin{array}{l}\text { Shovelnose sturgeon (Scaphirhynchus } \\
\text { platorynchus) }\end{array}$ & 2 & 24 & 26 \\
\hline Shovelnose sturgeon (YOY) & 26 & 85 & 111 \\
\hline Stonecat (Noturus flavus) & 7 & 76 & 83 \\
\hline Unidentified Cyprinidae & 0 & 1 & 1 \\
\hline Unidentified chub (Hybognathus spp.) & 2 & 4 & 6 \\
\hline Walleye (Sander vitreus) & 0 & 1 & 1 \\
\hline Total & 253 & 1,489 & 1,742 \\
\hline
\end{tabular}

${ }^{1}$ Nonwild, hatchery-origin.

River upstream of the Yellowstone River confluence was 2011. Although discharge exceeded 100,000 ft/3/sec. in 2011, fish began their migration up the Missouri River with discharges of $25,000-30,000 \mathrm{ft}^{3} / \mathrm{sec}$. An enhanced response by pallid sturgeon at the low discharges in 2013 suggests that migration responses maybe affected by water quality or source, as well as discharge.

Egg biopsies from the two telemetered gravid pallid sturgeon indicated that they did not spawn in the Missouri River or Milk River; however, males were present and there were likely other untagged fish present without transmitters. Spawning may have happened, but gone undetected.

Documentation of use, spawning, and reproduction in the Missouri River in 2011 indicates that the Missouri River is used by pallid sturgeon when flow regimes are suitable regardless 
Table 21. Number of young-of-year shovelnose sturgeon collected in standard trawls, targeted trawls, minimum length, maximum length, and mean length in 2013 by date.

[n, number of samples]

\begin{tabular}{lcccccc}
\hline \multicolumn{1}{c}{ Date } & $\begin{array}{c}\text { Total } \\
(\boldsymbol{n})\end{array}$ & $\begin{array}{c}\text { Standard } \\
(\boldsymbol{n})\end{array}$ & $\begin{array}{c}\text { Targeted } \\
(\boldsymbol{n})\end{array}$ & $\begin{array}{c}\text { Minimum length, } \\
\text { in millimeters }\end{array}$ & $\begin{array}{c}\text { Maximum length, } \\
\text { in millimeters }\end{array}$ & $\begin{array}{c}\text { Mean length, } \\
\text { in millimeters }\end{array}$ \\
\hline $7 / 31 / 2013$ & 13 & 9 & 4 & 19 & 71 & 47.3 \\
$8 / 7 / 2013$ & 15 & 8 & 7 & 29 & 85 & 66.4 \\
$8 / 13 / 2013$ & 26 & 10 & 16 & 27 & 105 & 68.8 \\
$8 / 20 / 2013$ & 26 & 6 & 20 & 16 & 138 & 45.6 \\
$8 / 26 / 2013$ & 9 & 4 & 5 & 17 & 27 & 22.6 \\
$9 / 3 / 2013$ & 22 & 6 & 16 & 21 & 116 & 41 \\
\hline
\end{tabular}

of temperature. Results of the 2011 study added substantial new information on pallid sturgeon movement, river use, and behavior. Verification of successful reproduction by wild pallid sturgeon has provided information that indicates spawning, fertilization, egg survival, and hatch can occur in the Missouri River when flows deviate from baseline operations.

Several years of information indicate that pallid sturgeon will move upstream in the Upper Missouri River when there are no flow enhancements and during one year (2011) when there was severe flooding. This suggests that there is the potential for improving conditions for pallid sturgeon spawning without flooding. Since very few sexually mature adult pallid sturgeon have been observed in the Missouri River, limited data exist that details the flow parameters required to stimulate wild pallid sturgeon migrations and spawning. Additional information to determine flows required to cue pallid sturgeon to migrate into the Upper Missouri River and retain them through the act of spawning would improve our understanding of the potential for Fort Peck Flow modifications to contribute to increased pallid sturgeon reproductive success and recruitment.

\section{Task 5: Missouri River Pallid Sturgeon Population Assessment Program Synthesis-Towards Understanding Population Trends of Pallid Sturgeon and Other Targeted Species}

In 2000, the U.S. Fish \& Wildlife Service issued the U.S. Army Corps of Engineers (USACE) a Biological Opinion (BiOp) for the Missouri River pallid sturgeon (U.S. Fish and Wildlife Service, 2000). To address USACE compliance activities the Pallid Sturgeon Population Assessment Program-PSPAP was developed (Drobish, 2005) based on the Missouri River Benthic Fish Study (Berry and others, 2004; Wildhaber and others, 2012). Through a series of concerted, multi-agency team efforts the USACE, with guidance from
USGS, developed a study design for the PSPAP and has been collecting data since 2003. In 2011, after the PSPAP had been on-going for 8 years, we began to analyze the full complement of data to assess what we have learned about pallid sturgeon and the other species targeted through the PSPAP. As such, the USACE requested CERC scientists and their university collaborators provide analysis and interpretation of 2003-10 PSPAP data designed to help guide Missouri River management efforts.

The result of this work has been development of capture probability, survival rate, and population estimates for Lower Missouri River wild and hatchery-produced pallid sturgeon and wild shovelnose sturgeon (Scott Holan, University of Missouri, written commun., 2015). Relative abundance of these two sturgeon species along with other PSPAP targeted species also was analyzed using methods similar to those used in the Missouri River Benthic Fishes Study (Wildhaber and others, 2012). The latter work provided comparative results to relative abundance patterns observed for 1996 to 1998 of the Missouri River Benthic Fishes Study. All the results from this work and the recent work of others (for example, Steffensen and others, 2010; 2012) made it apparent that the original population viability analyses (PVA) for pallid sturgeon (Bajer and Wildhaber, 2007) needed to be revisited.

This work includes (1) the assessment of relative abundance patterns for all PSPAP target species in each PSPAP defined study area of the Missouri River main-stem that PSPAP terms universes (Lower Monitoring Area - Gavins Point Dam to Missouri River Mouth; Middle Monitoring Area-Fort Randall Dam to Lewis and Clark Lake headwaters; Upper Monitoring Area- Fort Peck Dam to Lake Sakakawea headwaters). This includes environmental covariates (for example, water temperature, depth, and velocity) in individual species models and further development of bivariate (that is, simultaneous analysis of sympatric species) analyses; (2) the development of multistate (that is, spatially referenced) population and survival rate estimates for the Lower Missouri River along with assessment of potential tag retention impacts; (3) the development of an update of the PVA done by Bajer and Wildhaber (2007) using current (2015) survival 
and population estimates that include parameter uncertainty. This assessment is intended to evaluate factors related to relative abundance of pallid sturgeon, survival of hatchery-origin pallid sturgeon, the best available estimates of populations of wild and hatchery-origin pallid sturgeon, and an update pallid sturgeon PVA to facilitate recovery efforts; (4) laboratory studies designed to inform spatially explicit aspects of submodels within the population model also are included. Studies of the effect of food, temperature, and turbidity on substrate selection of young-of-year and early juvenile Missouri River sturgeon and associated chubs are done to refine survival and growth metrics for population and habitat models. These modeling efforts are ongoing and quantitative results are preliminary.

\section{Missouri River Pallid Sturgeon Population Assessment Program Synthesis-Relative Abundance with Environmental Covariates and Bivariate Analyses}

This study attempts to determine relative abundance of pallid sturgeon and shovelnose sturgeon, and other species targeted by PSPAP, using the same set of analyses done previously for the Missouri River Benthic Fishes Study (Wildhaber and others, 2011b). The goal is to provide comparative results to relative abundance patterns observed for 1996 to 1998 for the Missouri River Benthic Fishes Study. This should provide a better understanding of the relation of relative abundance of PSPAP target species to environmental conditions (for example, turbidity, temperature, and habitat). In doing this, information becomes available as to the primacy of these various environmental conditions to population numbers, and thus, what (if any) management actions could potentially be used to affect those conditions. In addition, this work includes attempts at applying the bivariate analyses developed using the Missouri River Benthic Fishes Study by Arab and others (2012).

\section{Methods}

This work is focused on using a similar approach as developed using the USACE Missouri River Benthic Study data by Arab and others (2008) and Wildhaber and others (2011b) using zero-inflated poisson (ZIP) or zero-inflated negative binomial models in a Bayesian framework. Relative abundance of pallid sturgeon and other species targeted by PSPAP are being analyzed to help identify factors related to changes in relative abundance that include continuous, environmental variables. In all these analyses, the three PSPAP sampling universes are being handled separately.

\section{Progress and Results}

The approach selected allows analyses to be performed on PSPAP data that are impossible or difficult to analyze with classic methods such as ANOVA and traditional regression. The approach allows fish population abundance patterns to be assessed in space and time without disregarding important issues such as the effect of gear efficiency and detection probability on presence of sampling and structural zeros. Additionally, this approach provides for comparisons of gear performance among fish species.

Conditioning and review of the available data have indicated that it is sparse, and therefore it has required the preliminary testing of many more models than originally anticipated. To construct macrohabitat associations, it was necessary to use a separate set of nested models. Simultaneously, it became apparent that inclusion of continuous, environmental variables would require a new set of models and analyses to accommodate the fact that environmental variables were collected less frequently in the dataset than the fish were sampled. However, preliminary results suggest a combination of similar and differing results among PSPAP universes, and among macrohabitats within bends compared to when macrohabitats were directly compared.

In addition, ongoing studies attempt to apply the bivariate ZIP (BivZIP) modeling approach developed using USACE Missouri River Benthic Fish data by (Arab and others, 2012) to key pairings of species targeted by PSPAP to try to assess their similarity in relative abundance pattern and how that might relate to environmental change. The sparseness of the data and limited overlaps among various target species complicates the analyses and has impeded progress.

\section{Discussion}

The Bayesian approach used to fit the ZIP model provides a potentially powerful and comprehensive inference that allows use of random effects and random intercept in the model because of uncertainties existing in the data collection procedures (that is, uncertainty about optimal sampling design, measurement and sampling errors) and lack of confidence about involvement of appropriate covariates (that is, other physical or ecological variables for which data are not available). In addition a Bayesian approach uses prior knowledge about model parameters (for example, gear efficiency, species preferred macrohabitats, and previously observed population numbers, results from previous studies, and other expert opinions) to select and evaluate possible models. This approach is straightforward and allows for multiple comparisons to obtain information on gear performance.

The success in application of the analytical approaches selected to such a complex dataset is always dependent on the quantity and quality of the data that are available. However, previous results with similar data indicates that these zeroinflated, Bayesian-based approaches, along with being highly informative, have a much greater chance of being successful even when other common methods are not. For instance, these approaches are generally more robust for datasets with higher percentages of zero catches (or observations) and, in the case 
of BivZIP, greater success is achieved for datasets with limited overlap in species occurrence.

A major issue with analytical approaches to such a large, spatial-temporal dataset is presenting the vast number of complex model results in an acceptable form for publication and the need for meticulous efforts by multiple people to insure accuracy.

\section{Missouri River Pallid Sturgeon Population Assessment Program synthesis-Tag Retention Effects on and Spatial Context of Pallid Sturgeon Capture Probability, Survival Rate, and Population Size}

Survival rates of stocked pallid sturgeon have been estimated to be $0.051(\mathrm{SE}=0.008)$ for age-0 fish and $0.686(\mathrm{SE}=$ 0.117 ) for age-1 fish (Steffensen and others, 2010). Although not typically stocked under current (2015) management standards, the survival rate of age-1+ fish increased to 0.922 (SE $=0.015$ ) when used (Steffensen and others, 2010). Previous analyses on capture probability, survival rate, and population size done on a more complete set of data under this task suggest that survival rates and population size for hatchery-origin pallid sturgeon may not be as high when a more complete set of data for the whole Lower Missouri River is considered, and when tag loss is considered. As a result it is possible that pallid sturgeon and shovelnose sturgeon populations are not increasing at the rate expected.

The Pallid Sturgeon Range-Wide Stocking and Augmentation Plan recommends stocking age-1 fish at a rate of 24.5 fish per river $\mathrm{km}$ per year and limiting offspring stocked from a single female to 10,000 (U.S. Fish and Wildlife Service, 2008). The success of these stocking efforts is dependent on the survival of the stocked fish. Preliminary analyses previously done under this task determined that there were concentrations of stocked fish in the upper part of the Lower Missouri River where they had been stocked, whereas no such concentration of stocked fish was documented in the lower part of the Lower Missouri River near its mouth where fish also were stocked. The latter observation may suggest higher mortality for age- 0 and age- 1 hatchery-origin pallid sturgeon stocked in the lower part of the Lower Missouri River upstream of the mouth. Results also may be explained by high rates of emigration from the Missouri River into the Mississippi River. In the Upper Missouri River, stocked juveniles do not disperse immediately (Oldenburg and others, 2011). These observations make the locations chosen for stocking key in improving survivorship.

Recently (2015), concern has arisen related to unknown passively integrated transponder (PIT) tag loss rates and their potential significance on survival and population estimates. If tag loss was high (unknown, but suggested to be as high as 49 percent, U.S. Fish and Wildlife Service, 2008), the current (2015) estimates of capture probabilities, survival rates, and population size could be low. Simultaneously, the combination of these results with those presented by Steffensen and others (2012) seemed to indicate that most of the Lower Missouri River hatchery-origin pallid sturgeon population could be located in the $80.5 \mathrm{~km}$ reach associated with the mouth of the Platte River. Therefore, the two key concerns here are whether or not tag loss may be resulting in lower than actual survival and population estimates for pallid sturgeon and if the distribution of pallid sturgeon in the Lower Missouri River are truly concentrated in one small reach as current (2015) estimates would suggest.

\section{Methods}

We are assessing the impacts of tag retention on pallid sturgeon survival rates and population size and developing a spatially referenced (for example, segment level) model for population size and survival rate for hatchery (and wild if possible) pallid sturgeon populations in the Lower Missouri River using approaches outlined in DeLonay and others (2014). We are assessing tag retention effects from two possible directions. The first direction is to use any available double tagging data that potentially exist in the PSPAP and data from other available studies (Hamel and others, 2012; Hamel and others, 2013). If the data are too limited or do not exist, multiple tag retentions rates determined in the range of previously observed rates (U.S. Fish and Wildlife Service, 2008) are being assessed for their potential impact of survival and population estimates through simulation studies. For spatially referenced capture probability, survival rates, and population size, we are developing spatially referenced (starting with segment) capture probabilities, survival rates, and estimates of population size.

\section{Progress and Results}

We are in the process of completing the tag retention and spatial distribution aspects of the pallid sturgeon survival analyses. Preliminary results suggest that the most recent population estimates given by Steffensen and others (2012) may be high if they are to be used to represent the Lower Missouri River as a whole. In addition, tag retention simulations suggest that the major change in population estimates that result from tag loss is increased uncertainty in estimates.

\section{Missouri River Pallid Sturgeon Population Assessment Program Synthesis_-Pallid Sturgeon Population Model and Population Viability Analyses}

Bajer and Wildhaber (2007) developed initial agestructured models for pallid sturgeon and shovelnose sturgeon populations in the Lower Missouri River to conduct a PVA for both species. Within the range of variables evaluated, both species models were most sensitive to age- 0 mortality rates, 
along with being sensitive to mortality rates of juveniles and young adults. Wildhaber and others (2007a, 2011a) presented a conceptual life-history model for pallid and shovelnose sturgeon that illustrated the importance of transition probabilities (that is, survival rate estimates in Bajer and Wildhaber [2007]) of the various life stages in determining population structure. The value of these models is the ability to provide a form of forecast of future populations under changing environmental and management conditions. Because of the limited knowledge of the biology of the pallid sturgeon at the time, many of the parameter estimates for these models were either from other sturgeon species or were based on anecdotal observations. Since then, studies have developed actual estimates of survival of age- 0 , age- 1 , age- $2+$ pallid sturgeon, along with measures of uncertainty (for example, Steffensen and others, 2010; Steffensen and others, 2012). Another example is that CSRP research is providing additional data on age-at-maturation and reproductive cycling (DeLonay and others, 2009; Albers and others, 2013) for pallid sturgeon. These additions, alone, have made it apparent that the original PVA for pallid sturgeon (Bajer and Wildhaber, 2007) needs to be revisited.

\section{Methods}

Following Bajer and Wildhaber (2007), development of an updated population model for pallid sturgeon is ongoing. Revised parameter estimates used in the population model have been selected from recently published studies (for example, Steffensen and others, 2010; Steffensen and others, 2012), the CSRP data on growth, age at first reproduction, frequency of spawning, proportion of females reproducing, fecundity, and spawning success, and any other improved estimates that can be obtained. In addition, this updated model will include, where obtainable, parameter uncertainty through inclusion of estimate distributions.

\section{Progress and Results}

Ongoing analyses follow from the previous section on updating the Bajer and Wildhaber (2007) population model for pallid sturgeon using current (2015) parameter estimates and inclusion of parameter uncertainty. Since actual estimates and their uncertainty now exist for many of the parameters Bajer and Wildhaber (2007) used in their model, the revised model under construction includes stochastic elements based on observed parameter distributions. As part of the development of the model, similar sensitivity analyses as were done by Bajer and Wildhaber (2007) were constructed to assess how the new parameter estimates and model structure may have changed what was previously concluded. In addition, a userfriendly, desktop tool based on Bajer and Wildhaber (2007) is under construction that allows the user to change multiple aspects of the model to simulate the potential effects of those changes on pallid sturgeon populations.
Bajer and Wildhaber (2007) completed a sensitivity analysis and varied population parameter estimates by likepercentages (for example, 5 percent, each). Results indicated that populations of shovelnose sturgeon and pallid sturgeon were most sensitive to age- 0 mortality rates as well as mortality rates of juveniles and young adults. Fecundity was a less sensitive parameter. However, increased fecundity effectively balanced higher mortality among sensitive age classes in both populations. The evaluation of reproductive values by Bajer and Wildhaber (2007) indicated that pallid sturgeon populations dominated by ages $\geq 35$ could rapidly lose their potential to increase, particularly if recruitment remains low. Further analyses will determine if these conclusions hold true with updated parameter estimates and the inclusion of uncertainty. Input from stakeholders and managers has been solicited to improve the model user-interface so that on completion of the updated model the framework for dissemination and use of the latest model will be in place.

\section{The Effect of Food, Temperature, and Turbidity on Substrate Selection of Young-of-Year and Early Juvenile Missouri River Sturgeon and Associated Chubs}

Estimating the population viability of Scaphirhynchus sturgeons through the young-of-year and juvenile stage hinges on elucidating the primary natural and anthropogenic factors that contribute to survival during these periods. For the young-of-year and early juvenile stages, restricted availability and intake of food may reduce growth rates, alter distributions, and limit densities of individuals across habitat types (Deng and others, 2003). To ensure adequate growth and survival of young sturgeon, food availability must be high and competition must be low for these life stages to successfully recruit to the adult population within any given river reach. Both sturgeon species have to deal with intra- and interspecific competition at each life stage because of the number of benthic species found in the Missouri River (Berry and others, 2004), all of which may be directly competing for space and food resources. Each of these benthic species may use slightly different habitat, food resources, and feeding strategies to reduce competition and improve foraging success. However, in highly modified habitats, the availability and distribution of food resources may reduce foraging success and increase competition of some species. Recent field studies have demonstrated that juvenile pallid and shovelnose sturgeon use the same habitat during nonwinter periods when rates of food consumption and growth are expected to be greatest (Gerrity and others, 2008). Observations of white sturgeon in overwintering areas suggest that these areas contain high densities of sturgeon creating the potential for intense competition for food and habitat resources (Golder Associates Ltd., 2006).

The pallid sturgeon is highly adapted to large, turbid, riverine environments, and are believed to avoid smaller tributaries or clear-water riverine habitats frequented by shovelnose 
sturgeon (Mayden and Kuhajda, 1997). Dietary studies of young-of-year and juvenile shovelnose and pallid sturgeon indicate that both primarily feed on invertebrates, including chironomids, trichopterans, and ephemeropterans (Hoopes, 1960; Held, 1969; Modde and Schmulbach, 1977; Gerrity and others, 2006; Braaten and others, 2007; Hoover and others, 2007; Wanner and others, 2007). The specific mode of feeding, the ability of young sturgeon to feed on drifting organisms, and the effects of temperature, turbidity, and substrate on feeding have not been thoroughly examined.

Bramblett and White (2001) suggest that pallid sturgeon exhibit some selectivity for sand substrate in the Missouri River, although the strength of this selection may be affected by temperature, turbidity, or other water-quality characteristics. Water is well-mixed in these large rivers and spatial variation in temperature, turbidity, or other water quality properties that might affect habitat choice are only apparent at the reach scale in features like tributary mouths, side-channels, backwaters, or areas behind wing dikes that are cut off from main-channel flows (Galat and others, 2001). Since sand is the primary substrate present in the Missouri and Mississippi Rivers and we have no pre-alteration data on habitat selection, it is not clear whether temperature, turbidity, and substrate associations observed for shovelnose and pallid sturgeon documented in the field are the result of habitat preference or the predominance of those habitats.

Recent evidence indicates that several Macrhybopsis chubs are important food of pallid sturgeon adults (Gerrity and others, 2006; Hoover and others, 2007). Because they are thought to use the same habitat these chubs may be potential competitors for young-of-year and early juveniles. Populations of these chub species have declined recently (2015); presumably for many of the same reasons as pallid sturgeon (Hesse and others, 1989; Galat and others, 2005). Declines in these species, therefore, may hinder growth and development in adult pallid sturgeon, while simultaneously decreasing competition for young-of-year and early juveniles.

To increase our understanding of the factors affecting the observed habitat choices of shovelnose and pallid sturgeon in the field (DeLonay and others, 2009; Reuter and others, 2009; Bonnot and others, 2011), their habitat choices in the laboratory under controlled conditions must be investigated. Critical decisions on how to manage the Missouri River system for habitat to facilitate conservation and recovery of sturgeon depend on understanding the habitat types required by the fish.

Confounded with the question of habitat choice is food availability. Even if young-of-year and juvenile pallid and shovelnose sturgeon are able to find preferred habitat, if the necessary food resources are not present in those habitats poor growth and survival will result. Hence, the objective of this study is to assess habitat choice as it relates to food availability and the strength of their linkage for young-of-year and juvenile pallid and shovelnose sturgeon relative to water temperature, turbidity, and substrate. Additionally, the intent of this work is to document potential differences in habitat choices between pallid and shovelnose sturgeon young-of-year and juveniles, and chub species to better understand the potential competition for resources between species and whether or not management actions may potentially affect these species differently.

\section{Methods}

A laboratory study designed to understand habitat and food selection of juvenile sturgeon and the shoal chub (Macrhybopsis hyostoma) was done in 2013. The objective of this study was to assess habitat choice as it relates to food availability, examining the strength of substrate selection in the presence of food and whether that selection changed with varying levels of turbidity. The purpose of studying both sturgeon species along with chubs was to gain a better understanding of the potential competition for resources between species and whether or not management actions affect the species differently.

The CERC laboratory study consisted of a series of 24 isolated aquaria each equipped with their own computer controlled lighting (visual and infrared) and heating system. Each tank was assigned a random combination of clay and sand substrate relative to tank side, resulting in a half clay/half sand, tank-bottom. One fish was placed in each tank and tanks were continuously monitored using a closed-circuit camera and digital video recorder. To test light intensity as a surrogate for turbidity, one-half of the tanks were given complete, continuous darkness (monitored under infrared), whereas the other one-half of tanks were given a 12 hour light: 12 hour dark photocycle. To test food consumption (that is, growth rates), one-half of each of the two lighting groups were fed a maximum ration daily, whereas the other one-half was fed one-half of that maximum ration. To test the effect of food on substrate choice, delivery of food to a given substrate type (that is, clay or sand) was randomized among tanks and compared to habitat choice without food.

In the aquaria studies, for each species, proportional usage of a substrate data will be compared using a factorial model with a Latin square component in time based on the study design. This is expected to provide information on the effects of food ration, food location, temperature, and photoperiod on substrate and differences among species.

\section{Progress and Results}

Preliminary observations from these studies suggest pallid sturgeon and shovelnose sturgeon seem to choose foraging over clay compared to sand, at least under zero velocity conditions. Chubs show less substrate-related selection but similarity in habitat choice among all species, indicating that there is potential for competition and thus, possible limitations of habitat and food resources. Data collected during these studies is still being analyzed. Results from these studies are expected to provide initial data needed to model the potential population impacts of these behaviors in the context of available food and 
habitat present in the Lower Missouri River. This information is useful for developing the submodel for the juvenile life stage in the overall sturgeon population model (Bajer and Wildhaber, 2007; Wildhaber and others, 2007a) as part of a larger adaptive management approach directed at increasing pallid sturgeon populations through habitat alteration within the Missouri River. This work is designed to provide an assessment of the innate habitat choice of pallid sturgeon and shovelnose sturgeon young-of-year and early juveniles and chub species without flow. These experiments test how food availability and habitat selection are linked.

\section{Task 6: Hatch, Dispersal and Settling Behavior of Early Life-Stage Pallid Sturgeon from Egg Through First Feeding}

Sturgeons have evolved a downstream dispersal strategy by early life stages that transports them from spawning and hatch locations to downstream rearing areas (Kynard and others, 2007). The species specific morphology and expression of behaviors of developing sturgeons affect their downstream dispersal distance. Dispersal behaviors may differ markedly among sturgeon species, and among geographic races or subpopulations (Khodorevskaya and others, 2009). Shovelnose and pallid sturgeon initiate dispersal immediately after hatch as free embryos, but differ in the duration of the free-embryo drift stage before transitioning to the benthic larval stage (Kynard and others, 2007; Braaten and others, 2008). In laboratory and field studies of sturgeon from the Upper Missouri River and Yellowstone Rivers, the duration of the drift stage for pallid sturgeon (11-17 days) was about twice as long as that for shovelnose sturgeon (4-6 days) (Kynard and others, 2007; Braaten and others, 2008). These findings indicate that under similar hydraulic conditions, pallid sturgeon require a longer stretch of free-flowing river to complete the ontogenetic drift cycle compared to shovelnose sturgeon.

Little is known about the drift behavior of sturgeon from genetically differentiated subgroups from downstream parts of the species range or pallid $\mathrm{x}$ shovelnose sturgeon hybrids. The downstream subgroups may exhibit different dispersal behaviors than those from the most upstream population and the hybrids may express intermediate dispersal behaviors.

The overall objectives of this task are to develop an understanding of normal Scaphirhynchus behaviors from hatch through first feeding in the laboratory to lay the foundation for future research on dispersal dynamics of sturgeon in the Missouri River. Our main objectives are to quantify survival and stage specific dispersal behaviors of newly hatched embryos through first-feeding of Scaphirhynchus species and pallid sturgeon subgroups under the same set of experimental conditions (that is, flow, temperature, and water quality). The goal is to identify morphological and innate behavioral traits that accelerate or reduce downstream drift between Scaphirhynchus species and among pallid sturgeon subgroups.

\section{Methods}

Fish

Two lots of pallid sturgeon embryos were obtained from Columbia Environmental Research Center (CERC) Columbia, Mo. Both lots were the progeny of artificially spawned Upper Missouri River Basin stock, but from different parents. Embryos of lot PLS-2 were spawned on May 23, 2013, and were transported to the Yankton Field Research Station (FRS) by vehicle at 3-days post-fertilization. Embryos of lot PLS-4 were spawned on June 20, 2013, and were shipped, by overnight carrier, to the Yankton FRS at 4-days post-fertilization and approximately 60 percent of the embryos had hatched on arrival. On arrival at the Yankton FRS, the embryos were acclimated to the culture water temperature at $17-18{ }^{\circ} \mathrm{C}$ (PLS-2 at $19{ }^{\circ} \mathrm{C}$ and PLS- 4 at $20^{\circ} \mathrm{C}$ on arrival) over a period of 2-4 hours and then partly acclimated to the culture water quality by a series static-renewal water replacements.

The embryos were hatched in a miniature egg incubator system constructed by James Candrl at the USGS, CERC. The system is based on McDonald or Downing hatching jar devices where water is delivered through a tube to the rounded bottom of jars or cylindrical vessels containing the eggs (Piper and others, 1982). The incubation tubes (50-milliliter; $25 \mathrm{~mm}$ x $200 \mathrm{~mm}$ Pyrex glass) were fitted with a 250-micron $(\mu)$ nylon screen around the top of the tube to retain the hatched embryos.

The free embryos, destined for the testing, were held in 1-liter plastic jars with three 6.5 -centimeter $(\mathrm{cm})$ diameter holes covered with $250-\mu$ nylon screen and fitted with a float ring (2.5-cm thick Styrofoam ring wrapped with Teflon tape) near the top of the jar and a lid with a set of small diameter holes. The float ring kept the jars submersed to within about $3 \mathrm{~cm}$ from the top. The jars were placed in the 1.2-m fiberglass circular stream tank and kept in constant motion by the water current in the tank provided by a pump driven recirculation system. Temperature control was provided by an in-line aquarium chiller unit.

\section{Flume System}

The behavior experiments were done in a fiberglass oval flume system (fig. 50). The flume system consisted of two $1.2 \mathrm{~m}$ long straight runs connected to two $180^{\circ}$ bends and measured about $4.3 \mathrm{~m}$ in maximum length. The channel was $40 \mathrm{~cm}$ (16 in) wide at the top, $38 \mathrm{~cm}$ (15 in) wide at the bottom, and $50 \mathrm{~cm}$ (20 in) deep.

Water level was maintained at $40 \mathrm{~cm}$ (16 in) in the first experiment (PLS-2) and $30 \mathrm{~cm}$ (12 in) in the second experiment (PLS-4) with standpipes placed outside of the flume. 


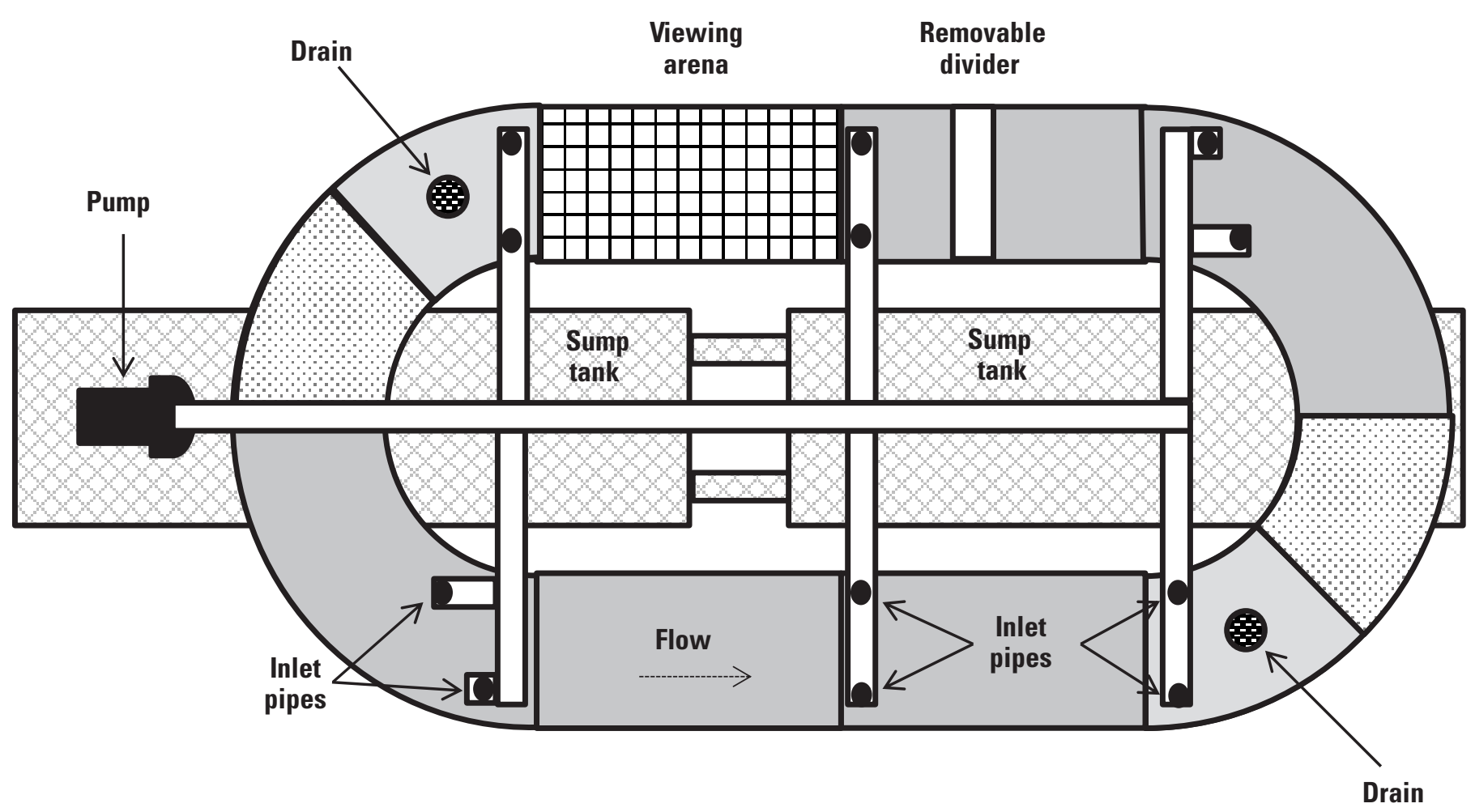

Figure 50. Experimental flume system used for dispersal studies with early life stage pallid sturgeon (Scaphirhynchus albus). Diagram depicts approximate location and sizes of viewing arena, drains, inlet pipes, pump, and sump tanks; diagram is not drawn to scale.

There were two drains on the flume bottom that allowed water to drain into two $473 \mathrm{~L}$ (125-gallon) reservoir tanks that were plumbed together below the flume. The drains inside the flume were covered with a ramp-screen cap that consists of a 30.5 $\mathrm{cm}$ (12 in) $x 40.1 \mathrm{~cm}$ (16 in) solid piece of aluminum at the upstream side of the drain and a $30.5 \mathrm{~cm}$ (12 in) x $40.1 \mathrm{~cm}$ (16 in) screen at the downstream side. Water from the reservoir tanks was pumped back into the flume using a set of vertical spray bars $(2.5 \mathrm{~cm}$ polyvinyl chloride pipe with four $2 \mathrm{~mm}$ diameter holes) to create the velocity. In the first experiment, we used four vertical spray bars placed along the inside wall upstream and downstream from the two bends. Based on observations in the first experiment (described below), we used 12 spray bars plumbed in pairs at 6 locations and a strip of nylon mesh sealed along the bottom attached to each vertical bar for the second experiment. The purpose of the additional spray bars and nylon strips was to diffuse and reduce the force (shear) of the microcurrents of water exiting the holes, thereby lessoning the physical trauma to embryos that came in contact with the microcurrents. Water in the reservoir tank was constantly circulated through an aquarium chiller unit to maintain the test temperature $\left(17\right.$ plus or minus $\left.1{ }^{\circ} \mathrm{C}\right)$.

A viewing arena, $92 \mathrm{~cm}$ long, was placed in one of the straight sections by gluing white polyethylene panels along the bottom and both sides. An array of four waterproof closedcircuit television (CCTV) cameras with $3.6 \mathrm{~mm}$ fixed focus lens and 8 infrared (IR) light-emitting diodes (LEDs), for operating in the dark, was deployed in the downstream part of the arena. To minimize turbulence and impingement of fish on the cameras and wires, the cameras were mounted in $5-\mathrm{cm}$ PVC pipe with the lens flush with the surface and the wires inside. Two additional CCTV cameras were deployed; one was placed upstream from the viewing arena to record fish that had just entered the straight section and other was downstream from the viewing arena to record fish passing over a drain ramp. The cameras were programmed to record continuously to an 8-channel digital video recorder (DVR) when fish were in the flume. A monitor was attached to the DVR for viewing the recordings. The video clips were downloaded from the DVR to portable hard drives at least twice daily. A high resolution infrared camera was mounted above the viewing arena to record fish passing over a reference point. The camera recorded images to a laptop computer. In experiment 2, a small polyethylene platform (12 cm wide x $38 \mathrm{~cm}$ long) was suspended across the channel at mid depth for monitoring fish location in the water column (upper or lower half).

\section{Test Water}

The fish were cultured and tested in a nonstandard reconstituted water (table 22) designed to simulate the major water quality characteristics (without trace inorganic contaminants) of the Missouri River near Sioux City, Iowa (located about 0.5 mile upstream from the USGS streamgage 06486000; table 2 in Christiansen, 2004). 
Table 22. Water quality measured in culture units, flume, and blending tanks.

[Data are mean \pm 1 standard deviation and range. $\mathrm{mg} / \mathrm{L}$, milligram per liter; $\mathrm{CaCO}_{3}$, calcium carbonate; $\mathrm{nm}$, not measured; $n$, number of samples; $\mathrm{nr}$, not reported; $\%$, percent; $\mathrm{SU}$, standard unit; $\mu \mathrm{S} / \mathrm{cm}$, microsiemen per centimeter; ${ }^{\circ} \mathrm{C}$, degrees Celsius]

\begin{tabular}{|c|c|c|c|c|}
\hline \multirow{2}{*}{$\begin{array}{l}\text { Constituent } \\
\text { (unit) }\end{array}$} & \multicolumn{4}{|c|}{ Source } \\
\hline & Culture & Flume & $\begin{array}{l}\text { Blending } \\
\text { tanks }\end{array}$ & Missouri River ${ }^{a}$ \\
\hline \multicolumn{5}{|c|}{ Major parameters measured ex-situ } \\
\hline Hardness & $204 \pm 3$ & $205 \pm 4$ & $205 \pm 4$ & $210 \pm 17$ \\
\hline$\left(\mathrm{mg} / \mathrm{L}\right.$ as $\left.\mathrm{CaCO}_{3}\right)$ & 200-209 & $198-210$ & $196-211$ & $200-240$ \\
\hline Calcium & $51 \pm 1$ & $52 \pm 1$ & $53 \pm 1$ & $52 \pm 2$ \\
\hline$(\mathrm{mg} / \mathrm{L})$ & $49-53$ & $50-55$ & $52-54$ & $50-56$ \\
\hline Magnesium & $18 \pm 1$ & $18 \pm 1$ & $18 \pm 1$ & $19 \pm 3$ \\
\hline$(\mathrm{mg} / \mathrm{L})$ & $16-19$ & $16-19$ & $16-19$ & $18-24$ \\
\hline Alkalinity & $155 \pm 3$ & $160 \pm 2$ & $159 \pm 3$ & $155^{\mathrm{b}} \pm 7$ \\
\hline$\left(\mathrm{mg} / \mathrm{L}\right.$ as $\left.\mathrm{CaCO}_{3}\right)$ & $148-160$ & $157-165$ & $149-164$ & $149-168$ \\
\hline Chloride & $14 \pm 1^{c}$ & $11 \pm 1$ & $\mathrm{~nm}$ & $10 \pm 2$ \\
\hline$(\mathrm{mg} / \mathrm{L})$ & $10-21$ & $10-12$ & & $9.4-14$ \\
\hline Sulfate & $153 \pm 4^{\mathrm{d}}$ & $156 \pm 3^{\mathrm{e}}$ & $\mathrm{nm}$ & $161 \pm 2$ \\
\hline$(\mathrm{mg} / \mathrm{L})$ & $146-158$ & $152-159$ & & $159-163$ \\
\hline$n$ & 12 & 11 & 24 & 5 \\
\hline \multicolumn{5}{|c|}{ Physical parameters, measured in-situ } \\
\hline Dissolved oxygen & $7.6 \pm 0.4$ & $9.1 \pm 0.2$ & $9.0 \pm 0.2$ & $6.6 \pm 0.4$ \\
\hline$(\mathrm{mg} / \mathrm{L})$ & $6.9-9.0$ & $8.2-9.3$ & $8.8-9.3$ & $5.9-6.9$ \\
\hline Dissolved oxygen & $83 \pm 5$ & $99 \pm 2$ & $103 \pm 1$ & $\mathrm{nr}$ \\
\hline (\% saturation) & $75-100$ & 89-101 & $102-104^{\mathrm{f}}$ & \\
\hline $\mathrm{pH}$ & $8.3 \pm 0.1$ & $8.4 \pm 0.1$ & $7.8 \pm 0.3$ & $8.1 \pm 0.04$ \\
\hline (SU) & $8.2-8.5$ & $8.2-8.5$ & $7.2-8.3$ & $8.0-8.1$ \\
\hline Conductivity & $637 \pm 15$ & $644 \pm 7$ & $640 \pm 10^{\mathrm{g}}$ & $669 \pm 19$ \\
\hline$\left(\mu \mathrm{S} / \mathrm{cm}\right.$ at $\left.25^{\circ} \mathrm{C}\right)$ & $615-712$ & $629-657$ & $623-665$ & $654-701$ \\
\hline$n$ & 86 & 41 & 24 & 5 \\
\hline \multicolumn{5}{|c|}{$\begin{array}{l}{ }^{a} \text { Water quality measured in the Missouri River at Sioux City, Iowa, about } 0.5 \text { miles upstream from U.S. Geolog } \\
\text { cal Survey streamgage } 06486000 \text {, on June 6, } 2003 \text { (Christiansen, 2004). }\end{array}$} \\
\hline \multicolumn{5}{|c|}{ 'Estimated as the difference between the summed cations and anions. } \\
\hline \multicolumn{5}{|c|}{$\begin{array}{l}{ }^{\mathrm{c}} \text { Chloride concentrations were larger in samples collected during the period when fish were fed brine shrimp } \\
\text { nauplii }(19 \pm 2,16-21 \mathrm{mg} / \mathrm{L} ; n=4) \text { compared to those collected before the initiation of feeding }(11 \pm 1,10-13 \\
\mathrm{mg} / \mathrm{L} ; \mathrm{n}=8)\end{array}$} \\
\hline \multicolumn{5}{|l|}{${ }^{\mathrm{d}} n=10}$. \\
\hline \multicolumn{5}{|l|}{${ }^{\mathrm{e}} n=9$} \\
\hline \multicolumn{5}{|l|}{$\mathrm{f}_{\mathrm{i}}=5$} \\
\hline $\mathrm{g}_{n}=23$ & & & & \\
\hline
\end{tabular}


The water quality data for June were used because pallid sturgeon are presumed to spawn between April and June and most larval Scaphirhynchus have been collected from late May through mid-June in this reach of the Missouri River (DeLonay and others, 2009). Alkalinity was not measured by Christiansen (2004) and was estimated from the cationanion balance as difference between the summed concentrations (in milliequivalents/liter) of the cations and anions. The reconstituted water was prepared by adding appropriate amounts of mineral salts (pharmaceutical-grade or higher) to deionized water (DI) in 5,678-L (1,500 gallon) polyethylene tanks equipped with a recirculating pump to mix and aerate the water. Before usage, each tank of water was vigorously aerated for at least 1 day and a sample was collected for analyses of selected water quality characteristics (table 22) using standard methods (American Public Health Association and others, 1995). Water from the tanks was pumped through a stainless steel heat exchanger placed in a chiller box to cool the water to 17 plus or minus $1{ }^{\circ} \mathrm{C}$ before flowing to the flume and culture unit.

\section{Water Velocity and Quality}

Water velocity was measured daily in the stream tanks and flume with an electromagnetic meter (Marsh-McBirney Flo-mate 2000, Frederick, Maryland) or an acoustic Doppler velocimeter (SonTek FlowTracker Handheld ADV, San Diego, California). The velocimeter was used in experiment 2 after the electromagnetic meter malfunctioned. Water velocity measurements in the stream tank were collected at six points along a transect across the tank at the same depth as the center of the float jars. In the flume, velocity was measured at nine locations in each of six cross-sectional transects (fig. 50); three near the bottom, three at mid-depth, and three at just below the surface at the inside, middle, and outside section of the channel. At each transect, measurements were made at three depths (near bottom, mid-depth, and near surface) at each of three locations (near inside wall, middle of channel, and near outside wall).

Water temperatures in the stream tank and flume were continuously recorded with a data logger (Hobo Water Temp Pro v2, Onset Computer Corporation, Bourne, Massachusetts). Water temperatures in the same units also were monitored twice daily with a laboratory-grade digital thermometer and once daily with portable meters. Conductivity, dissolved oxygen (DO), $\mathrm{pH}$, and temperature were measured daily in both units using calibrated portable meters and water samples were collected weekly for general water quality analyses following standard methods (American Public Health Association and others, 1995).

\section{Experimental Procedures}

Two experiments were done in the flume system in 2013. Both studies consisted of a series of trials starting with newly hatched free embryos (0-days post-hatch, dph) and each successive trial was started with fish at that age from the same lot. Each trial was started by stocking 5 randomly selected fish (from the float jars) in the flume. Observations on survival and drift behavior were made at selected time intervals (described separately below for each study). Survival was measured before making the behavior observations (except for the first observation of a trial) to ensure that only live fish were being observed. To assess survival, the fish were collected into a 0.5 -L plastic jar filled with water from the flume. The dead and immobile fish were removed and preserved in 10 percent neutral buffered formalin (NBF). The live fish were re-stocked in the flume and allowed to acclimate for 5 minutes before the next behavior observations were made. A trial was terminated when there was greater than or equal to 80 percent functional mortality (combination of dead and immobile fish).

Experiment 1 was done with PLS-2 fish from late May to mid-June at nominal water velocity of $0.3 \mathrm{~m} / \mathrm{s}$ and depth $40 \mathrm{~cm}$ and was designed as a pilot study to establish the type of observations, observation schedule, depth, and water velocity for the second study based on survival, visibility of the fish, and the time required to find the fish in the flume. Experiment 2 was done with PLS-4 from late June to late July at a nominal water velocity of $0.3 \mathrm{~m} / \mathrm{s}$ and depth of $30 \mathrm{~cm}$.

Observations on survival and drift behavior were made at 5 minutes (drift behavior only), 1 hour, and then every 3 hours after the fish were initially stocked. The behaviors observed were the number of fish passes during one 5-minute period and location in the water column (upper or lower half) in a second 5-minute period. In trials with older fish, the orientation to the current also was monitored over a 5-minute period. The fish counts and location in the water column were made visually by one observer and by viewing the DVD images made by one of the submersed cameras (described previously in, "flume system") by a second observer. We later reviewed the video clips for the same time periods and averaged the counts made by the two observers for the number of fish passes and location.

The trials are done in the dark (to prevent the fish from orientating to light), except for one fluorescent fixture with two 40-watt cool white bulbs placed in red tubes and one lamp with a 40-watt red incandescent bulb that were mounted above the viewing area. Water in the flume system was renewed weekly by replacing at least one-half of water with fresh chilled $\left(17^{\circ} \mathrm{C}\right)$ reconstituted water.

\section{Growth and Development}

During both experiments, a sample of 5-10 fish was collected daily from the float jars and examined under a stereoscope for presence or absence of the melanin plug. The fish were then euthanized with tricaine methanesulfonate (MS222) and preserved in NBF for later measurement of growth. Total length was measured to $0.1 \mathrm{~mm}$ with a stereo microscope fitted with a calibrated ocular micrometer. The fish were weighed (preserved body weight) individually ( \pm 0.1 milligram [mg]) on an analytical balance. Before weighing, the fish was 
placed on a piece of $250-\mu$ nylon screen set on laboratory tissue to absorb the excess preservative.

Water temperatures from the logger in the stream culture tank were compiled into daily averages and summed to calculate the daily cumulative temperature units (CTU) that the fish had been exposed to as described in Kynard and others (2007). Cumulative degree-days were calculated to 10:00 AM each day when the fish were stocked into the flume system. The CTU were used to link development with thermal exposure in the culture unit.

\section{Data Analysis}

Routine statistical analyses were done using Microsoft Excel (2010) and Statistical Analysis System (SAS) for Windows software, version 9.2 (SAS Institute, Cary, North Carolina, 2008). Before final statistical analysis of the quantitative variables, the assumptions of normality and equal variance were formally tested by the Shapiro-Wilk and Levene's tests, respectively. Data not meeting these assumptions were transformed to ranks and the appropriate statistical test was applied to the ranks (Conover and Iman, 1981). Data on percentage of survival were arcsine square root transformed before analysis. Statistical significance probability ( $p$ ) was set at $p<0.05$ for all tests.

Median time to expulsion of the yolk plug and 95 percent confidence limits (CL) were calculated by the probit method using the computer program in Peltier and Weber (1985). Fulton-type condition factors were calculated for each fish by the formula of Anderson and Gutreuter (1983) as follows: Condition factor $=\left[\right.$ body weight $(\mathrm{mg}) /$ total length $\left.(\mathrm{mm})^{3}\right] \mathrm{x}$ 100.

\section{Progress and Results}

\section{Culture Conditions}

Daily average temperatures in the stream tank ranged from 15.7 to $16.8^{\circ} \mathrm{C}$ (mean, $16.4^{\circ} \mathrm{C}$ ) for PLS-2 and from 16.1 to $18.3^{\circ} \mathrm{C}$ (mean, $16.8^{\circ} \mathrm{C}$ ) for PLS-4. Dissolved oxygen concentrations were maintained at or above 75 percent air saturation and the $\mathrm{pH}$ ranged between 8.2 to 8.5 standard units (SU) (table 22). Total ammonia concentrations were less than $0.1 \mathrm{mg} / \mathrm{L}$ as Nitrogen $(\mathrm{N})$. The daily average water velocities in the stream tank ranged between 0.21 to $0.26 \mathrm{~m} / \mathrm{s}$ with a mean of $0.23 \mathrm{~m} / \mathrm{s}$ for PLS-2 and from 0.13 to $0.25 \mathrm{~m} / \mathrm{s}$ and $0.19 \mathrm{~m} / \mathrm{s}$ for PLS-4.

\section{Survival, Development, and Growth}

Overall survival of PLS-2 embryos cultured in the float jars for 11 days, normalized for daily sampling, was 90 percent (range: $74-100$ percent). For PLS-4, overall mean survival of fish reared in float jars for 23 days was 94 percent (range: $85-98$ percent).

Expulsion of the melanin plug in pallid sturgeon is commonly an indicator of the time when the fish has begun exogenous feeding and has transitioned from the free-embryo stage to the benthic larval stage. Based on the first day fish expelled their yolk plugs, free embryos started to transition into larvae at $14 \mathrm{dph}$ and $232 \mathrm{CTU}$ (table 23). The transition period extended over 7 days and was complete at $20 \mathrm{dph}$ and $332 \mathrm{CTU}$. Estimated median thermal exposure period for yolk plug expulsion was 264 (95 percent CL, 253-276) CTU, which occurred at 15 dph. None of the PLS-2 had expelled their yolk plugs by the end of experiment 1 when fish were at $11 \mathrm{dph}$ and $181 \mathrm{CTU}$.

\section{Flume Trials}

\section{Test Conditions}

Mean daily average water velocity in experiment 1 was $0.32 \mathrm{~m} / \mathrm{s}$ with a range of 0.30 and $0.34 \mathrm{~m} / \mathrm{s}$. The mean daily flows at the six transects differed by an average of $0.05 \mathrm{~m} / \mathrm{s}$ with a range of 0.02 to $0.1 \mathrm{~m} / \mathrm{s}$. In experiment 2, mean daily water velocities decreased over time as the nylon screens became progressively occluded with a precipitate. The average daily flows ranged from 0.11 to $0.27 \mathrm{~m} / \mathrm{s}$ with a mean of $0.22 \mathrm{~m} / \mathrm{s}$. The flume system was dismantled and cleaned after the daily average velocity had dropped to $0.11 \mathrm{~m} / \mathrm{s}$ and the daily average velocities after cleaning ranged from 0.22 to $0.27 \mathrm{~m} / \mathrm{s}$. The mean daily velocities at the six transects differed by an average of $0.04 \mathrm{~m} / \mathrm{s}$ with a range of 0.01 to $0.11 \mathrm{~m} / \mathrm{s}$.

Dissolved oxygen concentrations were maintained at or above 89 percent saturation and the $\mathrm{pH}$ ranged between 8.2 to 8.5 SU (table 22). Water temperatures in experiment 1 averaged $16.9^{\circ} \mathrm{C}$ with a range of 16.5 to $17.2{ }^{\circ} \mathrm{C}$. Water temperatures (recorded by logger) in experiment 2 averaged $17.1^{\circ} \mathrm{C}$ with a range of $16.1-18.2^{\circ} \mathrm{C}$, except for one 12.5 -hour period in trial 9 when the temperature gradually increased to $22.2^{\circ} \mathrm{C}$ because of a power failure to the chiller.

\section{Experiment 1}

The first five trials with 0-2-dph embryos were problematic in that it was not possible to find all of the fish in the flume in a timely manner to assess survival and consequently, some of the early observation times were missed. We also had difficulties in making accurate visual counts of the number of fish passes in water $40 \mathrm{~cm}$ deep.

In all of the trials, survival of embryos in the flume system was poor; none of the fish were able to survive longer than 1 day (fig. 51). However, the survival times increased with age; all 0-1-dph embryos and most of the 2-dph fish died within the first hour, most 3-6-dph fish died between 1 and 2 hours, most 7-9-dph fish died between 2 and 3 hours, and most 10-11-dph fish died after 4 hours. 
Table 23. Age, daily cumulative temperature units, development, and growth metrics of pallid sturgeon lots PLS-2 and PLS-4 used in experiments 1 and 2 .

[dph, days post-hatch; CTU, cumulative temperature unit; \%, percent; mm, millimeter; mg, milligram; $n$, number of samples; PLS, pallid sturgeon]

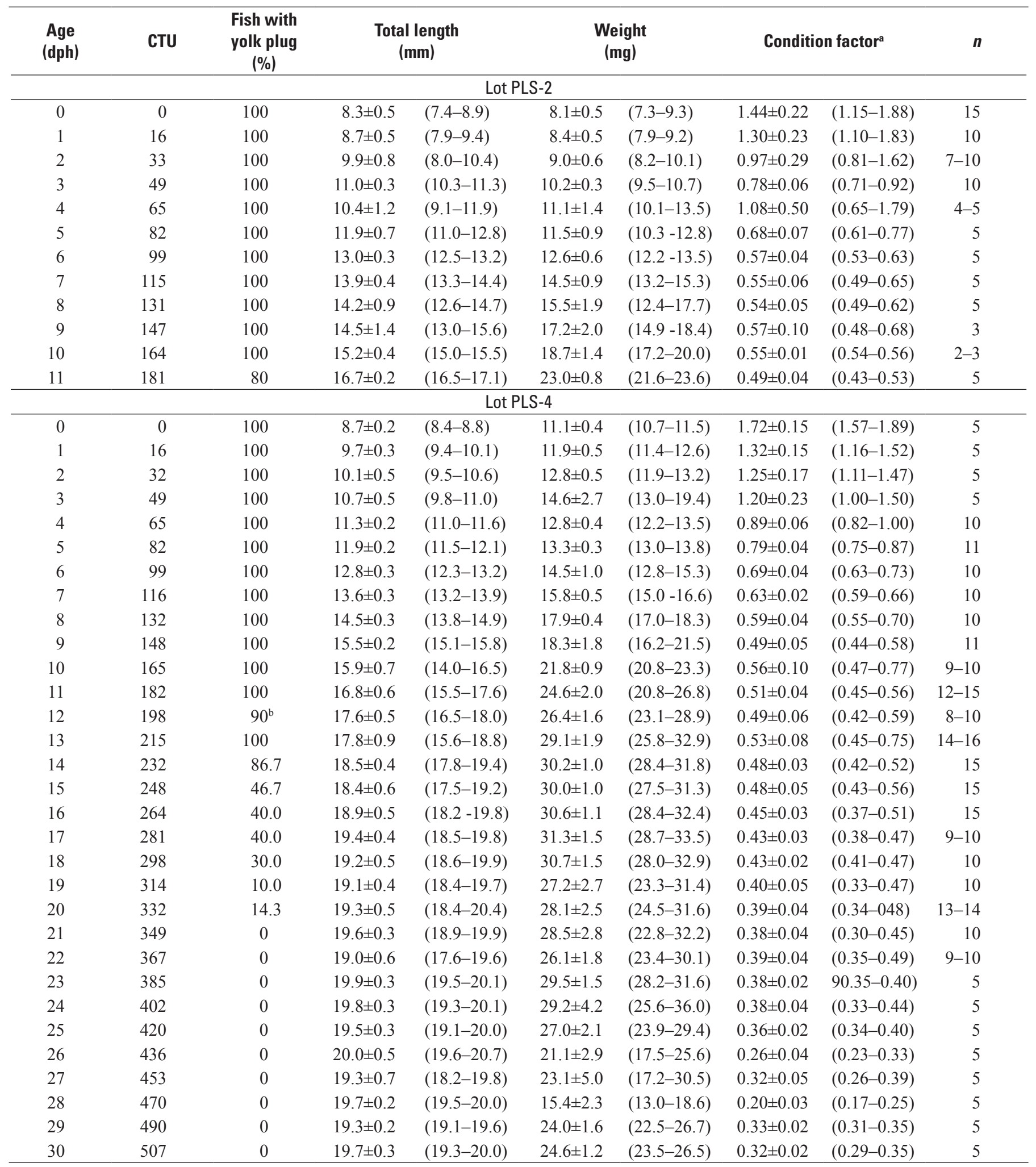

${ }^{a}$ Fulton-type condition factor, weight $(\mathrm{mg}) /$ total length $^{3}(\mathrm{~mm}) \times 100$.

'Yolk plug was likely expelled due to handling. 


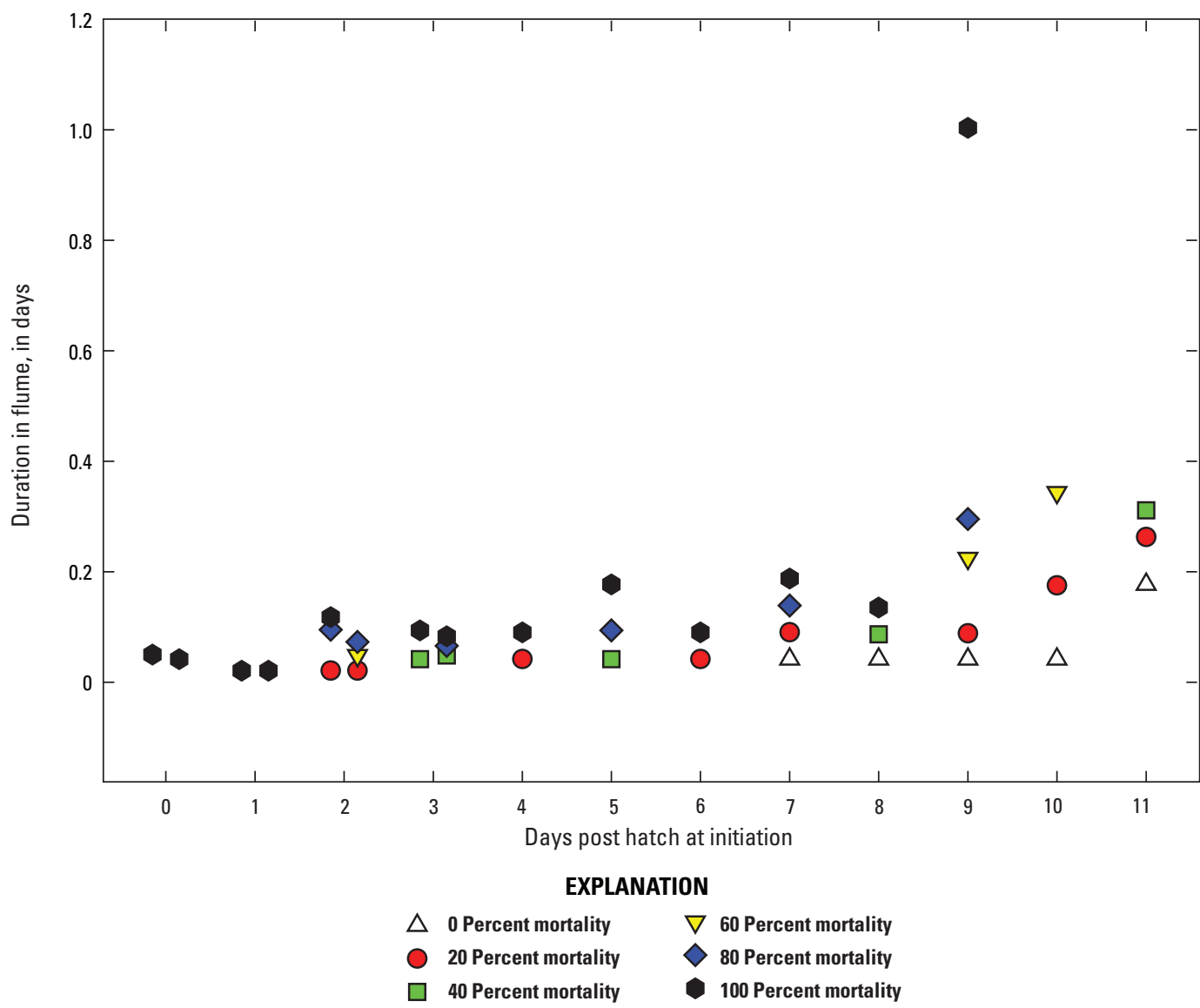

Figure 51. Cumulative percent mortality of different age pallid sturgeon embryos in relation to drift duration in the flume system for experiment 1.

Before the trial with 11-dph fish, we had repositioned one of the submersed cameras to view the area around one of the vertical spray bars. We observed that fish drifting too close to the holes in the spray bar became entrained in the strong turbulent microcurrents created by the force of water jetting from the holes. The fish were rolled or tumbled in the shooting flow and at times they hit the bottom or side of the flume and likely were fatally damaged. Based on these observations, we terminated the study and re-designed the water delivery system (described above for experiment 2).

\section{Experiment 2}

The duration of embryo survival in the flume system in these trials was considerably longer than that in experiment 1 , but varied with the age of the fish (fig. 52). In trials with 0-2 dph embryos, most fish survived between 9 to 12 hours. In trials with older fish at 3-6-dph and at 26-28-dph, most of the fish died within 6 hours. The longest survival duration was observed in the trial with 7-dph embryos, where 3 of 5 fish survived for 5 days and 1 fish survived for 6 days when the trial was terminated. In trials with fish at 13- and 17-dph, 2 of 5 fish survived for at least 2 days.

\section{Discussion}

Two survival and drift dispersal experiments were done with early life stage pallid sturgeon that involved the use of a large oval endless flume system that attempted to simulate a channelized reach of the Missouri River. One major obstacle was to design a water delivery system that provided water column velocities representative of those in the river without damaging the fish. The modifications made to the flume system for experiment 2 resulted in increased survival times compared to the original design. However, we are not able to discern whether the mortalities observed in experiment 2 were an artifact of the flume system or a response to hydraulic conditions in the water column. We plan on testing several modifications to the water delivery system and constructing a second flume system to test different water flows.

We designed and used reconstituted water that simulated the major cations and anions in the Missouri River near Sioux City, Iowa to culture and test the fish. The well waters at the Yankton FRS have high concentrations of manganese or iron that precipitate out when the water is aerated, and when used in the flume, the precipitate obscured the DVD images recorded by the infrared cameras. The water quality was determined to be suitable for rearing early life sturgeon and conducting behavior studies in the flume system. The water quality is reproducible for use in multiyear studies. 


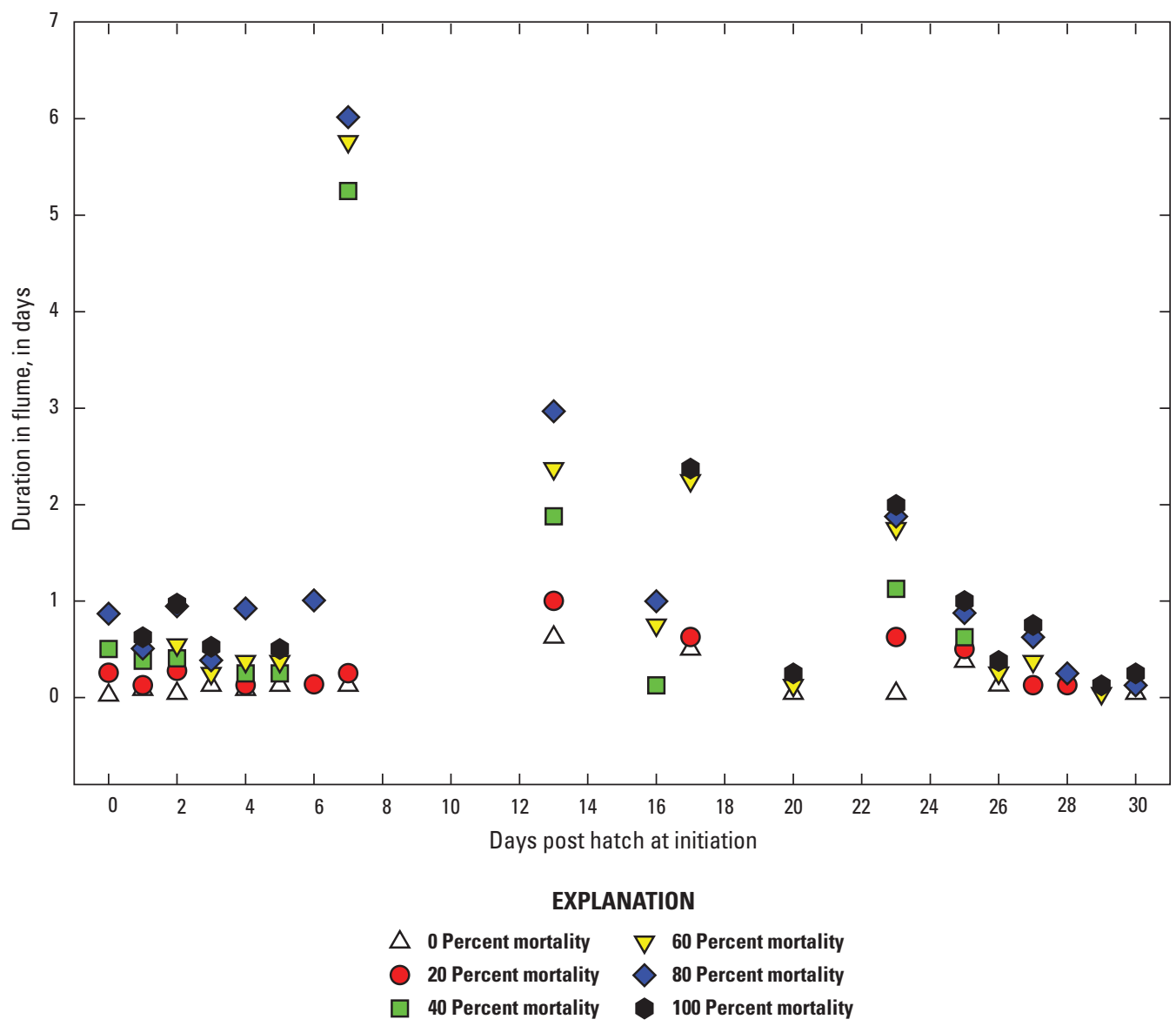

Figure 52. Cumulative percent mortality of different age pallid sturgeon embryos in relation to drift duration in the flume system for experiment 2.

We are in the process of reviewing the video clips of fish dispersal behaviors in the flume system to quantify the number of fish passes, dispersal in the water column, and orientation to the current, for different age embryos. The video clips also will be used to determine the age groups that expressed holding behavior in the channel and those capable of holding position. Data on fish passes will be used to estimate age-specific drift velocities and drift velocities will be compared to the water column velocity to estimate drift distances.

These experiments provided valuable insight into some of the difficulties involved with conducting dispersal studies with early life stage Scaphirhynchus and the information gained will be used to design the studies planned for 2014 .

\section{Summary and Conclusions}

The CSRP is an ongoing multidisciplinary research project conducted in cooperation with the U.S. Army Corps of Engineers Missouri River Recovery-Integrated Science Program. Studies under the CSRP in 2013 examined pallid sturgeon migration, spawning, hatch and free-embryo drift in four contrasting river sections in the Lower Missouri, Upper Missouri and Yellowstone Rivers. Recent (2015) research has emphasized validation and verification of successful spawning through the collection of eggs and free embryos at spawning locations, and the dynamics of free-embryo dispersal through laboratory studies of free-embryo behavior and hydraulic modeling of free-embryo dispersion and advection in the contemporary Missouri and Yellowstone Rivers. Data from the U.S. Army Corps of Engineers Pallid Sturgeon Population Assessment Program were synthesized and models developed to examine the effects of tag loss on population estimates and to continue the development of a quantitative population viability model for the pallid sturgeon.

Studies in the Lower Missouri River added to our understanding of where pallid sturgeon spawn and the habitats selected for spawning. Studies have documented spawning by female pallid sturgeon on 29 occasions in the Lower Missouri River and tributaries. Spawning in the Lower Missouri River is consistently on or along outside revetted banks in zones of swift deep water with converging flow. Spawning was once again inferred to have happened in the Platte River using data collected by data storage tags. Data indicate that adult pallid sturgeon that previously spawned in the Platte River will return to the Platte River to spawn in subsequent years. The precise location of spawning in the Platte River is unknown, and the habitat used is undescribed. No pallid sturgeon were collected below suspected spawning sites, or in continuous sampling in the Missouri River above the Platte River or in the Platte River near the mouth. Shovelnose sturgeon and 
paddlefish free embryos collected in the Lower Missouri River indicate that spawning is delayed in both species relative to downstream populations spawning near the mouth of the Missouri River, but paddlefish consistently spawn earlier than shovelnose sturgeon. As expected most free embryos were captured in or near the thalweg and collections included fewer late developmental stage free embryos than observed in samples collected near the mouth of the Missouri River in 2012.

Although pallid sturgeon migrated upstream in the Upper Missouri River below Fort Peck, telemetered fish spawned in the Yellowstone River in late June. Increased movement in the Upper Missouri River upstream from the Yellowstone River in 2013 may have been related to increased flows from the Milk River. In contrast to the Lower Missouri River, spawning in the Yellowstone River was over sorted gravel patches amid sand dunes in 2013. Spawning was verified through the collection of four pallid sturgeon free embryos, including two free embryos from telemetry-tagged female pallid sturgeon, code 40 and male pallid sturgeon, code 48 observed in a spawning aggregation on June 25 . No telemetered fish were known to have spawned in the Upper Missouri River above the confluence with the Yellowstone River and no pallid sturgeon free embryos were collected.

Pallid sturgeon migrating in the Lower Missouri River may actively avoid main channel habitats; whereas sturgeon migrating in the Upper Missouri and Yellowstone Rivers make use of the entire river. Hydraulic modeling of free-embryo dispersion and advection indicate that flow and channel engineering affect the rate of free-embryo dispersal and the potential for retention within river segments. Channel form and engineering also may affect where sturgeon spawn and where exogenously feeding larvae settle. Studies of the effects of channel dynamics on these lifestages may be critical to understanding the potential for re-engineering to improve reproduction and survival. Laboratory studies worked toward understanding free-embryo development and behavior during dispersion to provide parameters of active and passive drift to inform and improve hydraulic models.

Progress was made in 2013 in the evaluation of tag loss on estimates of pallid sturgeon abundance and survival of hatchery progeny. Evaluation of the uncertainties arising from tag loss is essential to assess the effectiveness of the Pallid Sturgeon Population Assessment Program and population augmentation program. Estimates of uncertainty will be incorporated in ongoing syntheses of data from the population assessment program, and other sources to complete an updated population model and viability analysis for pallid sturgeon.

\section{References Cited}

Albers, J.L., Wildhaber, M.L., and DeLonay, A.J., 2013, Gonadosomatic index and fecundity of lower Missouri and middle Mississippi River endangered pallid sturgeon estimated using minimally invasive techniques: Journal of Applied Ichthyology, v. 29, p. 968-977.

American Public Health Association, American Water Works Association, and Water Environment Federation, 1995, Standard methods for the examination of water and wastewater (19th ed.): Washington, D.C., American Public Health Association, $1100 \mathrm{p}$.

Anders, P.J., Richards, D.L., and Powell, M.S., 2002, The first endangered white sturgeon population-Repercussions in an altered large river-floodplain ecosystem: American Fisheries Society Symposium, v. 28, p. 67-82.

Anderson, R.O., and Gutreuter, S.J., 1983, Length, weight, and associated structural indices, in Nielsen, L.A., and Johnson, D., eds., Fisheries Techniques (1st ed.): Bethesda, Maryland, American Fisheries Society, p. 283-300.

Arab, A., Holan, S.H., Wikle, C.K., and Wildhaber, M.L., 2012, Semiparametric bivariate zero-inflated Poisson models with application to studies of abundance for multiple species: Environmetrics, v. 23, p. 183-196.

Arab, A., Wildhaber, M.L., Wikle, C.K., and Gentry, C.N., 2008, Zero-inflated modeling of fish catch per unit area resulting from multiple gears - Application to channel catfish and shovelnose sturgeon in the Missouri River: North American Journal of Fisheries Management, v. 28, no. 4, p. 1044-1058.

Bajer, P.G., and Wildhaber, M.L., 2007, Population viability analysis of Lower Missouri River shovelnose sturgeon with initial application to the pallid sturgeon: Journal of Applied Ichthyology, v. 23, no. 4, p. 457-464.

Bergman, H.L., Boelter, A.M., Parady, K., Fleming, C., Keevin, T., Latka, D.C., Korschgen, C., Galat, D.L., Hill, T., Jordan, G., Krentz, S., Nelson-Statsny, W., Olson, M., Mestl, G.E., Rouse, K., and Berkley, J., 2008, Research needs and management strategies for pallid sturgeon recovery-Proceedings of a workshop held July 31-August 2, 2007, St. Louis, Missouri: William D. Ruckelshaus Institute of Environment and Natural Resources, University of Wyoming, $37 \mathrm{p}$.

Berry, C.R., Wildhaber, M.L., and Galat, D., 2004, Population structure and habitat use of benthic fishes along the Missouri and lower Yellowstone rivers-Volume 3-Fish distribution and abundance: U.S. Geological Survey, Cooperative Research Unit, South Dakota State University and the University of Missouri, 268 p. 
Bonnot, T.W., Wildhaber, M.L., Millspaugh, J.J., DeLonay, A.J., Jacobson, R.B., and Bryan, J.L., 2011, Discrete choice modeling of shovelnose sturgeon habitat selection in the lower Missouri River: Journal of Applied Ichthyology, v. 27, no. 2, p. 291-230.

Braaten, P.J., and Fuller, D.B., 2005, Fort Peck flow modification biological data collection plan: summary of 2004 activities: Prepared for U. S. Army Corps of Engineers, no. Contract Number DACW45-03-P-0202, p. 62.

Braaten, P.J., and Fuller, D.B., 2007, Growth rates of youngof-year shovelnose sturgeon in the Upper Missouri River: Journal of Applied Ichthyology, v. 23, p. 506-515.

Braaten, P.J., and Fuller, D.B., 2010, Fort Peck flow modification biological data collection plan - Summary of 2009 Activities: Report prepared for the U.S. Army Corps of Engineers: Montana Department of Fish, Wildlife, and Parks.

Braaten, P.J., Fuller, D.B., Holte, L.D., Lott, R.D., Viste, W., Brandt, T.F., and Legare, R.G., 2008, Drift dynamics of larval pallid sturgeon and shovelnose sturgeon in a natural side channel of the upper Missouri River, Montana: North American Journal of Fisheries Management, v. 28, p. 808-826.

Braaten, P.J., Fuller, D.B., Lott, R.D., Haddix, T.M., Holte, L.D., Wilson, R.H., Bartron, M.L., Kalie, J.A., DeHaan, P.W., Ardren, W.R., Holm, R.J., and Jaeger, M.E., 2012a, Natural growth and diet of known-age pallid sturgeon (Scaphirhynchus albus) early life stages in the upper Missouri River basin, Montana and North Dakota: Journal of Applied Ichthyology, v. 28, p. 496-504.

Braaten, P.J., Fuller, D.B., Lott, R.D., and Jordan, G.R., 2009, An estimate of the historic population size of adult pallid sturgeon in the upper Missouri River Basin, Montana and North Dakota: Journal of Applied Ichthyology, v. 25, no. Supplement 2, p. 2-7.

Braaten, P.J., Fuller, D.B., Lott, R.D., and Ruggles, M.P., 2010, Spatial distribution of drifting pallid sturgeon larvae in the Missouri River inferred from two net designs and multiple sampling locations: North American Journal of Fisheries Management, v. 30, p. 1062-1074.

Braaten, P.J., Fuller, D.B., Lott, R.D., Ruggles, M.P., Brandt, T.F., Legare, R.G., and Holm, R.J., 2012b, An experimental test and models of drift and dispersal processes of pallid sturgeon (Scaphirhynchus albus) free embryos in the Missouri River: Environmental Biology of Fishes, v. 93, p. 377-392.

Braaten, P.J., Fuller, D.B., and McClenning, N.D., 2007, Diet composition of larval and young-of-year shovelnose sturgeon in the Upper Missouri River: Journal of Applied Ichthyology, v. 23, p. 516-520.
Bramblett, R.G., and White, R.G., 2001, Habitat use and movements of pallid and shovelnose sturgeon in the Yellowstone and Missouri rivers in Montana and North Dakota: Transactions of the American Fisheries Society, v. 130, no. 6, p. 1006-1025.

Carr, M.L., and Rehmann, C.R., 2007, Measuring the dispersion coefficient with acoustic Doppler current profilers: Journal of Hydraulic Engineering, v. 133, no. 8, p. 977-982.

Christiansen, D.E., 2004, Riverbed elevations and water quality of the Missouri River at Sioux City, Iowa, 2002-03: U.S. Geological Survey, 14 p.

Conover, W.J., and Iman, R.L., 1981, Rank transformations as a bridge between parametric and nonparametric statistics: The American Statistician, v. 35, no. 3, p. 124-129.

DeLonay, A.J., Jacobson, R.B., Annis, M.L., Braaten, P.J., Chojnacki, K.A., Elliott, C.M., Fuller, D.B., Haas, J.D., Haddix, T.M., McElroy, B.J., Mestl, G.E., Papoulias, D.M., Rhoten, J.C., and Wildhaber, M.L., 2014, Ecological requirements for pallid sturgeon reproduction and recruitment in the Missouri River-Annual report 2011: U.S. Geological Survey Open-File Report 2014-1106, 96 p.

DeLonay, A.J., Chojnacki, K.A., Jacobson, R.B., Albers, J.L., Braaten, P.J., Bulliner, E.A., Elliott, C.M., Erwin, S.O., Fuller, D.B., Haas, J.D., Ladd, H.L.A., Mestl, G.E., Papoulias, D.M., and Wildhaber, M.L., 2016, Ecological requirements for pallid sturgeon reproduction and recruitment in the Missouri River-A synthesis of science, 2005 to 2012: U.S. Geological Survey Scientific Investigations Report 2015-5145, 224 p. with appendixes [Also available at http://dx.doi.org/10.3133/sir20155145.]

DeLonay, A.J., Jacobson, R.B., Papoulias, D.M., Simpkins, D.G., Wildhaber, M.L., Reuter, J.M., Bonnot, T.W., Chojnacki, K.A., and Korschgen, C.E., 2009, Ecological requirements for pallid sturgeon reproduction and recruitment in the Lower Missouri River-A research synthesis 2005-08: U.S. Geological Survey Scientific Investigations Report 2009-5201, 59 p.

DeLonay, A.J., Jacobson, R.B., Papoulias, D.M., Wildhaber, M.L., Chojnacki, K.A., Pherigo, E.K., Bergthold, C.L., and Mestl, G.E., 2010, Ecological requirements for pallid sturgeon reproduction and recruitment in the Lower Missouri River-Annual report 2009: U.S. Geological Survey Open-File Report 2010-1215, 64 p.

DeLonay, A.J., Jacobson, R.B., Papoulias, D.M., Wildhaber, M.L., Chojnacki, K.A., Pherigo, E.K., Haas, J.D., and Mestl, G.E., 2012, Ecological requirements for pallid sturgeon reproduction and recruitment in the Lower Missouri River: Annual report 2010: U.S. Geological Survey OpenFile Report 2012-1009, 51 p. 
DeLonay, A.J., Papoulias, D.M., Wildhaber, M.L., Annis, M.L., Bryan, J.L., Griffith, S.A., Holan, S.H., and Tillitt, D.E., 2007, Use of behavioral and physiological indicators to evaluate Scaphirhynchus sturgeon spawning success: Journal of Applied Ichthyology, v. 23, no. 4, p. 428-435.

Deng, D.F., Koshio, S., Yokoyama, S., Bai, S.C., Shao, Q.J., Cui, Y.B., and Hung, S.S.O., 2003, Effects of feeding rate on growth performance of white sturgeon (Acipenser transmontanus) larvae: Aquaculture, v. 217, no. 1-4, p. 589-598.

Dettlaff, T.A., Ginsburg, A.S., and Schmalhausen, O.I., 1993, Sturgeon fishes-Developmental biology and aquaculture: Berlin, Springer-Verlag, $300 \mathrm{p}$.

Doyle, M., Murphy, D., Bartell, S., Farmer, A., Guy, C.S., and Palmer, M., 2011, Final report on spring pulses and adaptive management: Missouri River Recovery Program Independent Science Advisory Panel, U.S. Institute for Environmental Conflict Resolution, $64 \mathrm{p}$.

Drobish, M.R., 2005, Pallid sturgeon population assessment project, volume 1.0: U.S. Army Corps of Engineers, Omaha District, $48 \mathrm{p}$.

Elliott, C.M., Jacobson, R.B., and DeLonay, A.J., 2004, Physical aquatic habitat assessment, Fort Randall segment of the Missouri River, Nebraska and South Dakota: U.S. Geological Survey Open-File Report 2004-1060, p. 34.

Elliott, C.M., Reuter, J.M., and Jacobson, R.B., 2009, Channel morphodynamics in four reaches of the Lower Missouri River, 2006-07: U.S. Geological Survey Scientific Investigations Report 2009-5074, 258 p.

Fuller, D.B., and Braaten, P.J., 2012, Fort Peck flow modification biological collection plan compendium-A summary of 2001-2009 activities - Report prepared for the U.S. Geological Survey and the U.S. Army Corps of Engineers, Omaha District: Montana Department of Fish, Wildlife, and Parks, $122 \mathrm{p}$.

Fuller, D.B., Jaeger, M., and Webb, M., 2008, Spawning and associated movement patterns of pallid sturgeon in the lower Yellowstone River-Report submitted to the Western Area Power Administration, Upper basin pallid sturgeon work group: Montana Fish, Wildlife and Parks, 22 p.

Gaeuman, D., and Jacobson, R.B., 2005, Aquatic habitat mapping with an acoustic Doppler current profiler-Considerations for data quality: U.S. Geological Survey Open-File Report 2005-1163, 20 p.

Gaeuman, D., and Jacobson, R.B., 2006, Acoustic bed velocity and bed load dynamics in a large sand bed river: Journal of Geophysical Research, v. 111, p. 14.
Galat, D.L., Berry, C.R., Gardner, W.M., Hendrickson, J.C., Mestl, G.E., Power, G., Stone, C., and Winston, M.R., 2005, Spatiotemporal patterns and changes in Missouri River fishes: American Fisheries Society Symposium, v. 45, p. 249-291.

Galat, D.L., Wildhaber, M.L., and Dieterman, D.J., 2001, Spatial patterns of physical habitat-Volume 2-Population structure and habitat use of benthic fishes along the Missouri and lower Yellowstone rivers: U.S. Geological Survey, Cooperative Fish and Wildlife Research Unit, University of Missouri, $91 \mathrm{p}$.

Gerrity, P.C., Guy, C.S., and Gardner, W.M., 2006, Juvenile pallid sturgeon are piscivorous: A call for conserving native cyprinids: Transactions of the American Fisheries Society, v. 135 , no. 3, p. 604-609.

Gerrity, P.C., Guy, C.S., and Gardner, W.M., 2008, Habitat use of juvenile pallid sturgeon and shovelnose sturgeon with implications for water-level management in a downstream reservoir: North American Journal of Fisheries Management, v. 28, p. $832-843$.

Golder Associates Ltd., 2006, Upper Columbia River juvenile white sturgeon monitoring: phase 3 investigations, August 2004-February 2005: Golder Associates Ltd. Report No. 04-1480-051F, $67 \mathrm{p}$.

Gross, M.R., Repka, J., Robertson, C.T., Secor, D.H., and Van Winkle, W., 2002, Sturgeon conservation-Insights from elasticity analysis: American Fisheries Society Symposium, v. 28, p. $13-30$.

Hamel, M.J., Hammen, J.J., and Pegg, M.A., 2012, Tag retention of t-bar anchor tags and passive integrated transponder tags in shovelnose sturgeon: North American Journal of Fisheries Management, v. 32, no. 3, p. 533-538.

Hamel, M.J., Steffensen, K.D., Hammen, J.J., and Pegg, M.A., 2013, Evaluation of passive integrated transponder tag retention from two tagging locations in juvenile pallid sturgeon: Journal of Applied Ichthyology, v. 29, p. 41-43.

Heist, E.J., and Eichelberger, J., 2013, 2012 genetic analysis of Missouri River sturgeon larvae: Center for Fisheries, Aquaculture, and Aquatic Sciences, Southern Illinois University Carbondale, $27 \mathrm{p}$.

Held, J.W., 1969, Some early summer foods of the shovelnose sturgeon in the Missouri River: Transactions of the American Fisheries Society, no. 3, p. 514-517.

Hesse, L.W., Schmulbach, J.C., Carr, J.M., Keenlyne, K.D., Unkenholz, J.W., Robinson, J.W., and Mestl, G.E., 1989, Missouri River fishery resources in relation to past, present, and future stresses, in Proceedings on the International Large River Symposium: Canadian Sciences 106, p. 352-371. 
Hoopes, D.T., 1960, Utilization of mayflies and caddis flies by some Mississippi River fishes: Transactions of the American Fisheries Society, v. 89, no. 1, p. 32-34.

Hoover, J.J., George, S.G., and Killgore, K.J., 2007, Diet of shovelnose sturgeon and pallid sturgeon in the free-flowing Mississippi River: Journal of Applied Ichthyology, v. 23, p. 494-499.

Humphries, P., Serafini, L.G., and King, A., 2002, River regulation and fish larvae: variation through space and time: Freshwater Biology, v. 47, p. 1307-1331.

Hunziker, J.R., Haddix, T.M., Holte, L.D., and Lott, R.D., 2013, Pallid sturgeon population assessment and associated monitoring for the Missouri River-Segment 2-2012 Annual Report for the U.S. Army Corps of Engineers-Missouri River Recovery Program: Montana Department of Fish, Wildlife, and Parks, 111 p.

Jacobson, R.B., Elliott, C.M., and Johnson, H.E., 2004a, Assessment of shallow-water habitat availability in modified dike structures, lower Missouri River, 2004: U.S. Geological Survey Open File Report 2004-1409, 18 p.

Jacobson, R.B., and Galat, D.L., 2008, Design of a naturalized flow regime-An example from the Lower Missouri River, USA: Ecohydrology, v. 1, p. 81-104.

Jacobson, R.B., Johnson, H.E., and Dietsch, B.J., 2009, Hydrodynamic simulations of physical aquatic habitat availability for pallid sturgeon in the Lower Missouri River, at Yankton, South Dakota, Kenslers Bend, Nebraska, Little Sioux, Iowa, and Miami, Missouri, 2006-07: U.S. Geological Survey, Scientific Investigations Report 2009-5058, $67 \mathrm{p}$.

Jacobson, R.B., Johnson, H.E., Laustrup, M.S., D’Urso, G.J., and Reuter, J.M., 2004b, Physical habitat dynamics in four side-channel chutes, lower Missouri River: U.S. Geological Survey Open-File Report 2004-1071, 66 p.

Khodorevskaya, R.P., Ruban, G.I., and Pavlov, D.S., 2009, Behavior, migrations, distribution, and stocks of sturgeon in the Volga-Caspian Basin: Norderstedt, Germany, Books on Demand, 233 p.

Kim, D., 2012, Assessment of longitudinal dispersion coefficients using Acoustic Doppler Current Profilers in large river: Journal of Hydro-environment Research, v. 6, p. 29-39.

Kim, D., and Muste, M., 2012, Multi-dimensional representation of river hydrodynamics using ADCP data processing software: Environmental Modelling and Software, v. 38, p. 158-166.
Kynard, B., Henyey, E., and Horgan, M., 2002, Ontogenetic behavior, migration, and social behavior of pallid sturgeon, Scaphirhynchus albus, and shovelnose sturgeon, S. platorynchus, with notes on the adaptive significance of body color: Environmental Biology of Fishes, v. 63, no. 4, p. 389-403.

Kynard, B., Parker, E., Pugh, D., and Parker, T., 2007, Use of laboratory studies to develop a dispersal model for Missouri River pallid sturgeon early life intervals: Journal of Applied Ichthyology, v. 23, p. 365-374.

Mayden, R.L., and Kuhajda, B.R., 1997, Threatened fishes of the world: Scaphirhynchus albus (Forbes \& Richardson, 1905) (Acipenseridae): Environmental Biology of Fishes, v. 48, no. $1-4$, p. $420-421$.

McElroy, B., Delonay, A., and Jacobson, R., 2012, Optimum swimming pathways of fish spawning migrations in rivers: Ecology, v. 93, no. 1, p. 29-34.

Modde, T., and Schmulbach, J.C., 1977, Food and feeding behavior of the shovelnose sturgeon, Scaphirynchus platorhynchus, in the unchannelized Missouri River, South Dakota: Transactions of the American Fisheries Society, v. 106, no. 6, p. 602-608.

Oldenburg, E.W., Guy, C.S., Cureton, E.S., Webb, M.A.H., and Gardner, W.M., 2011, Effects of acclimation on poststocking dispersal and physiological condition of age-1 pallid sturgeon: Journal of Applied Ichthyology, v. 27, no. 2, p. 436-443.

Papoulias, D.M., DeLonay, A.J., Annis, M.L., Wildhaber, M.L., and Tillitt, D.E., 2011, Characterization of environmental cues for initiation of reproductive cycling and spawning in shovelnose sturgeon Scaphirhynchus platorynchus in the lower Missouri River, USA: Journal of Applied Ichthyology, v. 27, no. 2, p. 335-342.

Parsley, M.J., Anders, P.J., Miller, A.I., Beckman, L.G., and McCabe, G.T., 2002, Recovery of white sturgeon populations through natural production: understanding the influence of abiotic and biotic factors on spawning and subsequent recruitment: American Fisheries Society Symposium, v. 28, p. 55-66.

Peltier, W.H., and Weber, C.L., 1985, Methods for measuring the acute toxicity of effluents to freshwater and marine organisms: U.S. Environmental Protection Agency EPA 600/4-85/013, $216 \mathrm{p}$.

Piper, R.G., McElwain, I.B., Orme, L.E., McCraren, J.P., Fowler, L.G., and Leonard, J.R., 1982, Fish hatchery management: Washington, D.C., U.S. Fish and Wildlife Service. 
Quist, M.C., Boelter, A.M., Lovato, J.M., Korfanta, N.M., Bergman, H.L., Latka, D.C., Korschgen, C., Galat, D.L., Krentz, S., Oetker, M., Olson, M., Scott, C.M., and Berkley, J., 2004, Research and assessment needs for pallid sturgeon recovery in the Missouri River: Final report to the U.S. Geological Survey, U.S. Army Corps of Engineers, U.S. Fish and Wildlife Service, and U.S. Environmental Protection Agency, William D. Ruckelshaus Institute of Environment and Natural Resources, University of Wyoming, Laramie, 96 p.

Reuter, J.M., Jacobson, R.B., Elliott, C.M., and DeLonay, A.J., 2009, Assessment of lower Missouri River physical aquatic habitat and its use by adult sturgeon (genus Scaphirhynchus), 2005-07: U.S. Geological Survey Scientific Investigations Report 2009-5121, 81 p.

Reuter, J.M., Jacobson, R.B., Elliott, C.M., Johnson, H.E., III, and DeLonay, A.J., 2008, Hydraulic and substrate maps of reaches used by sturgeon (genus Scaphirhynchus) in the Lower Missouri River, 2005-07: U.S. Geological Survey Data Series 386, 442 p.

Scheidegger, K.J., and Bain, M.B., 1995, Larval fish distribution and microhabitat use in free-flowing and regulated rivers: Copeia, v. 1995, no. 1, p. 125-135.

Secor, D.H., Anders, P.J., Van Winkle, W., and Dixon, D.A., 2000, Can we study sturgeons to extinction? What we do and don't know about the conservation of North American sturgeons, in Biology, management, and protection of North American sturgeon, Van Winkle, W., Anders, P.J., Secor, D.H., and Dixon, D.A., eds. (28 ed.): Bethesda, Maryland, American Fisheries Society, p. 3-12.

Shen, C., Niu, J., Anderson, E.J., and Phanikumar, M.S., 2010, Estimating longitudinal dispersion in rivers using Acoustic Doppler Current Profilers: Advances in Water Resources, v. 33, p. 615-623.

Steffensen, K.D., Powell, L.A., and Koch, J.D., 2010, Assessment of hatchery-reared pallid sturgeon survival in the lower Missouri River: North American Journal of Fisheries Management, v. 30, p. 671-678.

Steffensen, K.D., Powell, L.A., and Pegg, M.A., 2012, Population size of hatchery-reared and wild pallid sturgeon in the lower Missouri River: North American Journal of Fisheries Management, v. 32, no. 1, p. 159-166.

Sustainable Ecosystems Institute, 2008, Review of comprehensive sturgeon research program: Sustainable Ecosystems Institute, $49 \mathrm{p}$.

Tripcevich, N., 2004, Flexibility by design-How mobile GIS meets the needs of archaeological survey: Cartography and Geographic Information Science, v. 31, no. 3, p. 137-151.
U.S. Army Corps of Engineers, 2004, Upper Mississippi River system flow frequency study: U.S. Army Corps of Engineers, $33 \mathrm{p}$.

U.S. Bureau of Reclamation, and U.S. Army Corps of Engineers, 2010, Intake diversion dam modification, lower Yellowstone project, Montana, final environmental assessment: U.S. Bureau of Reclamation, Billings, Montana and U.S. Army Corps of Engineers, Omaha, Nebraska, 230 p.

U.S. Bureau of Reclamation, and U.S. Army Corps of Engineers, 2012, Intake diversion dam modification, lower Yellowstone project, Montana-Draft supplement to the 2010 final environmental assessment: U.S. Bureau of Reclamation, Billings, Montana, and U.S. Army Corps of Engineers, Omaha, Nebraska, 98 p.

U.S. Fish and Wildlife Service, 2000, Biological opinion on the operation of the Missouri River main stem reservoir system, operation and maintenance of the Missouri River bank stabilization and navigation project, and operation of the Kansas River reservoir system: U.S. Fish and Wildlife Service, accessed on May 5, 2014, at http://www.nwd-mr. usace.army.mil/mmanual/opinion.html.

U.S. Fish and Wildlife Service, 2003, U.S. Fish and Wildlife Service 2003 amendment to the 2000 biological opinion on the operation of the Missouri River main stem reservoir system, operation and maintenance of the Missouri River bank stabilization and navigation project, and operation of the Kansas River reservoir system: U.S. Fish and Wildlife Service, 298 p.

U.S. Fish and Wildlife Service, 2007, Pallid sturgeon (Scaphirhynchus albus) 5-year review summary and evaluation: U.S. Fish and Wildlife Service, 120 p.

U.S. Fish and Wildlife Service, 2008, Pallid sturgeon (Scaphirhynchus albus) range wide stocking and augmentation plan: U.S. Fish and Wildlife Service, 55 p.

U.S. Fish and Wildlife Service, 2012, Biological procedures and protocols for researchers and managers handling pallid sturgeon: U.S. Fish and Wildlife Service, 40 p.

Wanner, G.A., Shuman, D.A., and Willis, D.W., 2007, Food habits of juvenile pallid sturgeon and adult shovelnose sturgeon in the Missouri River downstream of Fort Randall Dam, South Dakota: Journal of Freshwater Ecology, v. 22, no. 1, p. 81-92.

Wildhaber, M.L., DeLonay, A.J., Papoulias, D.M., Galat, D.L., Jacobson, R.B., Simpkins, D.G., Braaten, P.J., Korschgen, C.E., and Mac, M.J., 2007a, A conceptual life-history model for pallid and shovelnose sturgeon: U.S. Geological Survey Circular 1315, 18 p. 
Wildhaber, M.L., DeLonay, A.J., Papoulias, D.M., Galat, D.L., Jacobson, R.B., Simpkins, D.G., Braaten, P.J., Korschgen, C.E., and Mac, M.J., 2011a, Identifying structural elements needed for development of a predictive life-history model for pallid and shovelnose sturgeons: Journal of Applied Ichthyology, v. 27, no. 2, p. 462-469.

Wildhaber, M.L., Gladish, D.W., and Arab, A., 2012, Distribution and habitat use of the Missouri River and lower Yellowstone River benthic fishes from 1996 to 1998-A baseline for fish community recovery: River Research and Applications, v. 28, p. 1780-1803.
Wildhaber, M.L., Holan, S.H., Bryan, J.L., Gladish, D.W., and Ellersieck, M., 2011b, Assessing power of large river fish monitoring programs to detect population changes - The Missouri river sturgeon example: Journal of Applied Ichthyology, v. 27, no. 2, p. 282-290.

Wildhaber, M.L., Papoulias, D.M., DeLonay, A.J., Tillitt, D.E., Bryan, J.L., and Annis, M.L., 2007b, Physical and hormonal examination of Missouri River shovelnose sturgeon reproductive stage-A reference guide: Journal of Applied Ichthyology, v. 23, p. 382-401.

Wruck, W., Peuker, M., and Regenbrecht, C.R.A., 2012, Data management strategies for multinational large-scale systems biology projects: Briefings in Bioinformatics, p. 1-14. 
Publishing support provided by:

Rolla Publishing Service Center

For more information concerning this publication, contact: Director, USGS Columbia Environmental Research Center 4200 New Haven Road

Columbia, MO 65201

(573) 875-5399

Or visit the Columbia Environmental Research Center Web site at: http://www.cerc.usgs.gov/ 



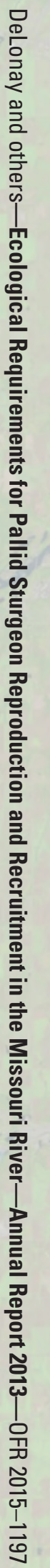

